Historic, Archive Document

Do not assume content reflects current scientific knowledge, policies, or practices. 



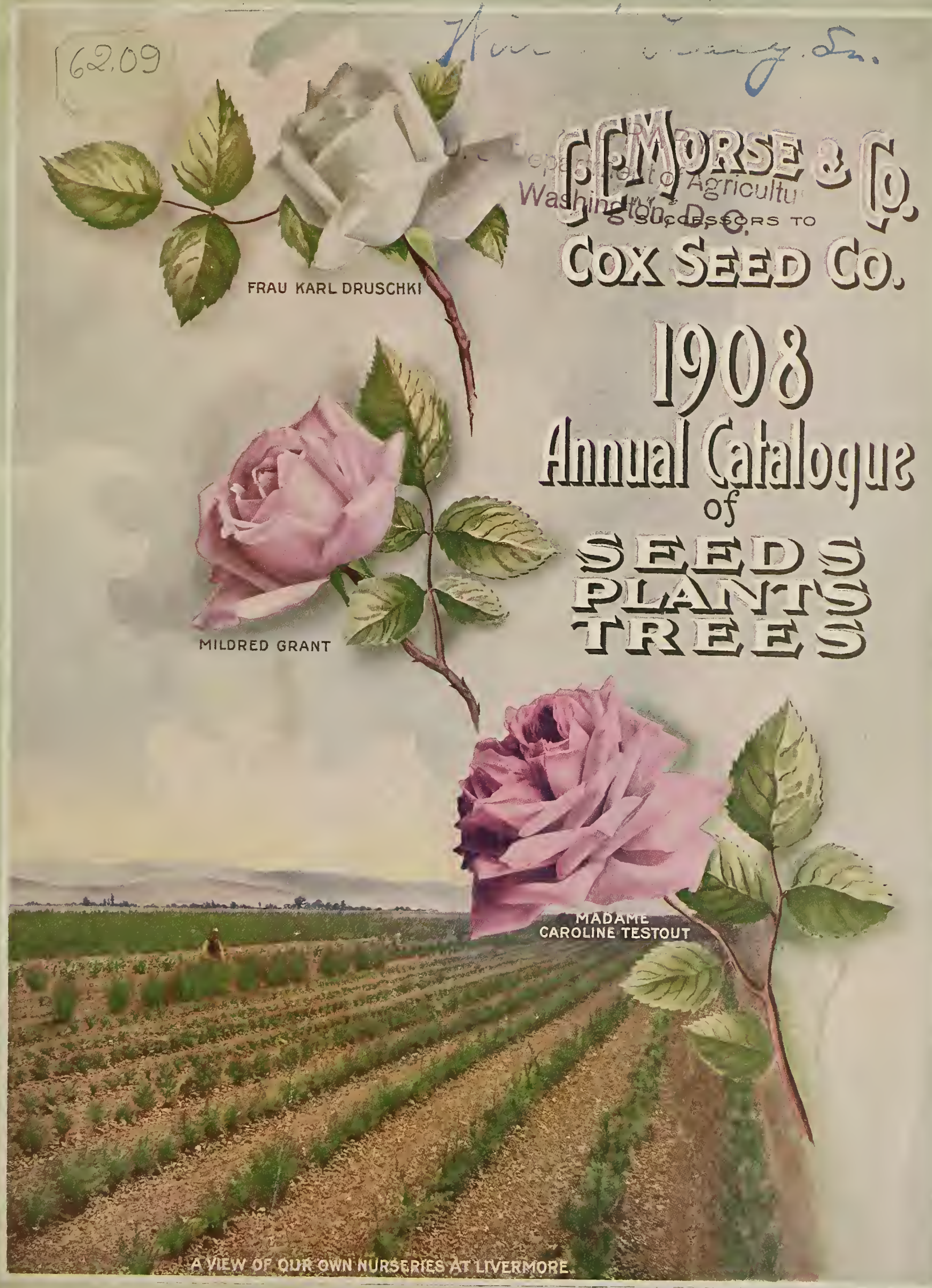




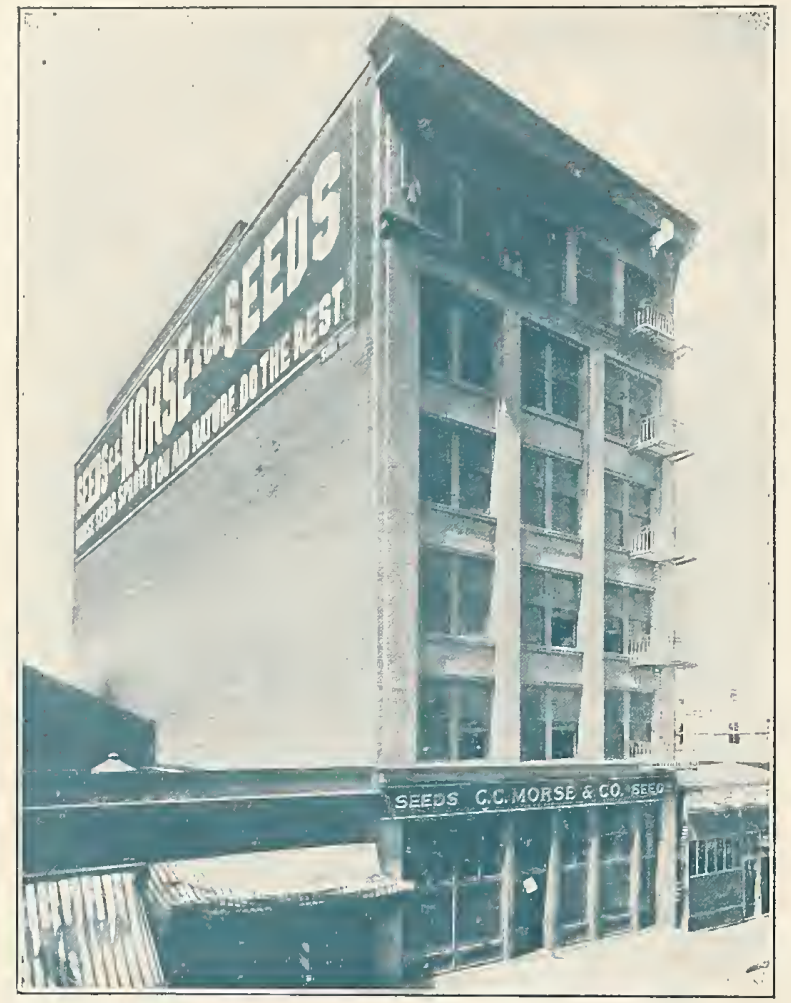

OUR NEW BUILDING

\section{To our Friends and Customers}

and also those of the Cox Seed Co.

A mong the many changes that followed the Great Fire in April I0O6, has been the consolidation of our business with that of the Cox Seed Co. Some two years ago we effected a consolidation witl the well know'n Seed House of $E$. J. Bowen, and now under our present arrangements we represent the combined interests of the three largest Seed Houses on the Pacific Coast.

In addition to our extensive Seed Growing business, which we have operated for the past thirty years in the Santa Clara Valley, we will continue all of the departments operated heretofore by the Cox Seed Co., which includes their Nurseries, Reiail Store, Catalogue Mail Business, Wholesale Department and the Commission Box Department. This latter feature of the business enables us to place an assortment of staple varietics of fiesh seeds all over the country, with merchants, and allows our customers to get certain seeds quickly at planting time, if they do not have time to send direct to us for them.

We are well equipped, in our new building illustrated here, are fully stocked with an excellent quality of seeds, plants and trees and hope to be favored with orders from all who are interested in the garden.

Respectfully' yours,

48-56 Jackson Street-General Offices and Wholesale

\begin{tabular}{ccccc}
\hline P L E A S E N O T E C A R E F U L L Y T H E F O L L O W I N G & OUR NURSERIES \\
Aur RETAIL STORE \\
125-127 Market Street, San Francisco
\end{tabular}

One and one-half blocks from the Ferry Building, on the South Side. Here we carry everything in the seed line, also tools, bulbs, and an assortment of plants. We keep a man in charge of our plant and tree department here, who is prepared to book any orders for nursery stock.

\section{OUR NURSERY SALESYARD AND GREENHOUSES}

Glen and Eleth Avenues. Oakland

All who are interested in plants, ornamental shrubs and trees and fruit trees, are cordially invited to visit our place here. You will find a valuable and interesting line of fine nursery stock. From San Francisco, take any Key Route boat, (leaving every twenty minutes) change to Piedmont train at the Mole and go to the end of the line. The nurseries are only one block up Glen avenue.
Two miles from the station. Here we grow some of our choicest ornamental stock, and fruit trees, roses, etc.

\section{OUR WHOLESALE COMMISSION BOX DEPARTMENTS AND GENERAL OFFICES}

Are at 48-56 Jackson street, in the building illustrated. Address all communications to us, here. Those interested in wholesale quantities, should call at this address.

\section{OUR SEED FARMS}

Headquarters are at Carnadero, near Gilroy

Here are our large seed farms or about 1,300 of our 2,000 acres. Неге also are our Trial Grounds, Sced Testing Grocnhouses and Farm Offices.

\section{Descriptions of the Three Roses Illustrated on First Page of this Cover}

\section{FRAU KARL DRUSCHKI (Hybrid Perpetual)}

Puresnow-white; very long buds; shell-shaped petals, opening to very large flowers; has been well shown and is the finest white rose in cultivation; extra fine; superb.

This is the description of the introducer, Mr. Lambert of Germany, and we can fully corrobate all he has said about this magnificent rose. It has been well tested in this state during the last two years and we send it out to the general public, knowing that it will give the best of satisfaction. Price of strong, ficld grown two year old plants, $50 \mathrm{c}$. each.

\section{BRIDESMAID}

In this exquisite Tea Rose we have an improved Catherine Mermet, from which it is a sport. Mermet, on account of its exquisite shape, large, solid, firm buds, with long stiff stems, has long been considered one of the best cut-flower varieties. Bridesmaid at all seasons is a clear, delicate pink, in all respects a counterpart of Mermet, with large, handsome, pointed buds on long stiff stems. Truo year old plants, $25 \mathrm{c}$. each.

Through printer's error the name of Mildred Grant was placed below rose No. 2 in place of Bridesmaid. For description of Mildred Grant, see page 67.

\section{MADAME CAROLINE TESTOUT (Hybrid Tea)}

This is not one of the newest introductions, but it is such a beautiful rose that we could not pass it over, but were anxious to bring this variety prominently before the rose loving world. The color is beautiful rose-pink, clear and lustrous; the buds and the full blown flower are exquisite; it is a long and continuous bloomer, blooming for eight months in the year, and producing an immense crop of flowers. The plant is of excellent constitution, being a strong, vigorous grower. Price of strong, field grown, truo jear old plants, 35c, each.

N. B. - The plants that we offer of the above three sorts, are strong, field grown, two year old, and will bloom the first spring and summer after planting, and must not be confounded with those small pot grown greenhouse plants, offered in the east at a low price. They are too la ge to go by mail and if ordered by themselves, we advise purchasers to have them sent by express. We will send one of each the abor't roses for $\$ 1.00$. 


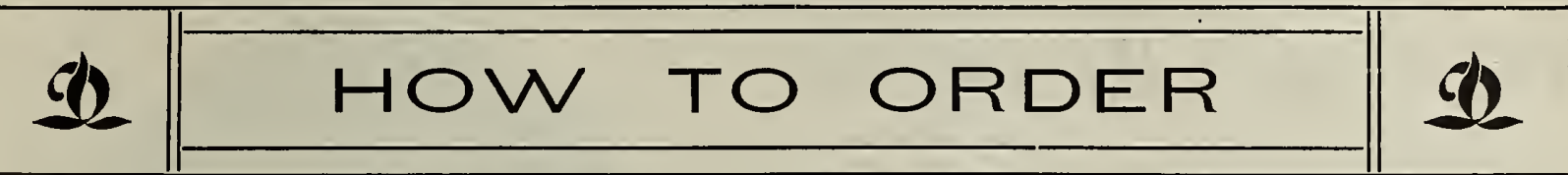

Be sure to write your NAME and ADDRESS plainly.

Unless otherwlse stated, we will pay postage on all packets, ounces, and one-pound packages or less. Larger quantities will be sent by express or freight, the charges to be paid by purchaser.

REMITTANCES in full must accompany all orders, and should be made by post-office or express money order, or by San Francisco exchange. Said remittances must include exchange. Personal checks will not bo accepted. Clean, unused STAMPS accepted up to amount of $\$ 1.00$.

Half-pound quantities will be filled at pound rates, but less than one-half pound at ounce rates.

NOTE.-There are so many contingencies to be encountered in growing plants from seed that are dependent on the weather and other conditions over which we have no control, that success in planting is not altogether dependent on the seed. We will send out only seed which we belleve will grow and produce the kind of plant and grow and produce the kind of plant and
variety represented; "but C. C. Morse \& Co. give no warranty, express or implied, as to description, quality, productiveness, or any other matter of any seeds they send out, and they will not be responsible in any way for the crop. If the purchaser does not accept the goods on these terms, they are at the goods on these term

\section{Florence Morse Spencer.}

OUR NEW SWEET PEA FOR 1908.

Beautifully illustrated on the back of our cover.

Pkt. of 50 seeds, $25 \mathrm{c}$

This cut illustrates the type, size and perfect form of the new Spencer types of Sweet Peas, which we offer in a splendid mixture called "Morse's superb."

\section{Morse's Superb Mixture Sweet Peas.}

A mixed assortment of about flfteen entirely new Sweet Peas, of the lighter and best shades, and all of the large petalled wavy types known as the Countess Spencer types. In this mixture we have put some of our best "selections," which we have not yet named, but which we hope to have ready for introduction next season. It would be impossible for any other seed grower in the world to offer a mixture to equal this one.

Offered in sealed packets only, 


\section{The Hoodoo Muskmelon}

Unlike its unpropitious name, this muskmelon is one of the best of recent introductions. It is early and prolific. The fruit is of medium size; the seed cavity very small; the rind very thin indeed; and the edible fleshy part very thick and meaty. It is of orange or salmon color, the type much preferred now. But its great charm is its flavor, which is par excellence. We have seldom had such enthusiastic reports from any vegetable novelty as from the Hoodoo Muskmelon. It will pay you to try it.

Pkt. 10c; oz. 75 c; Ib. $\$ 8.00$

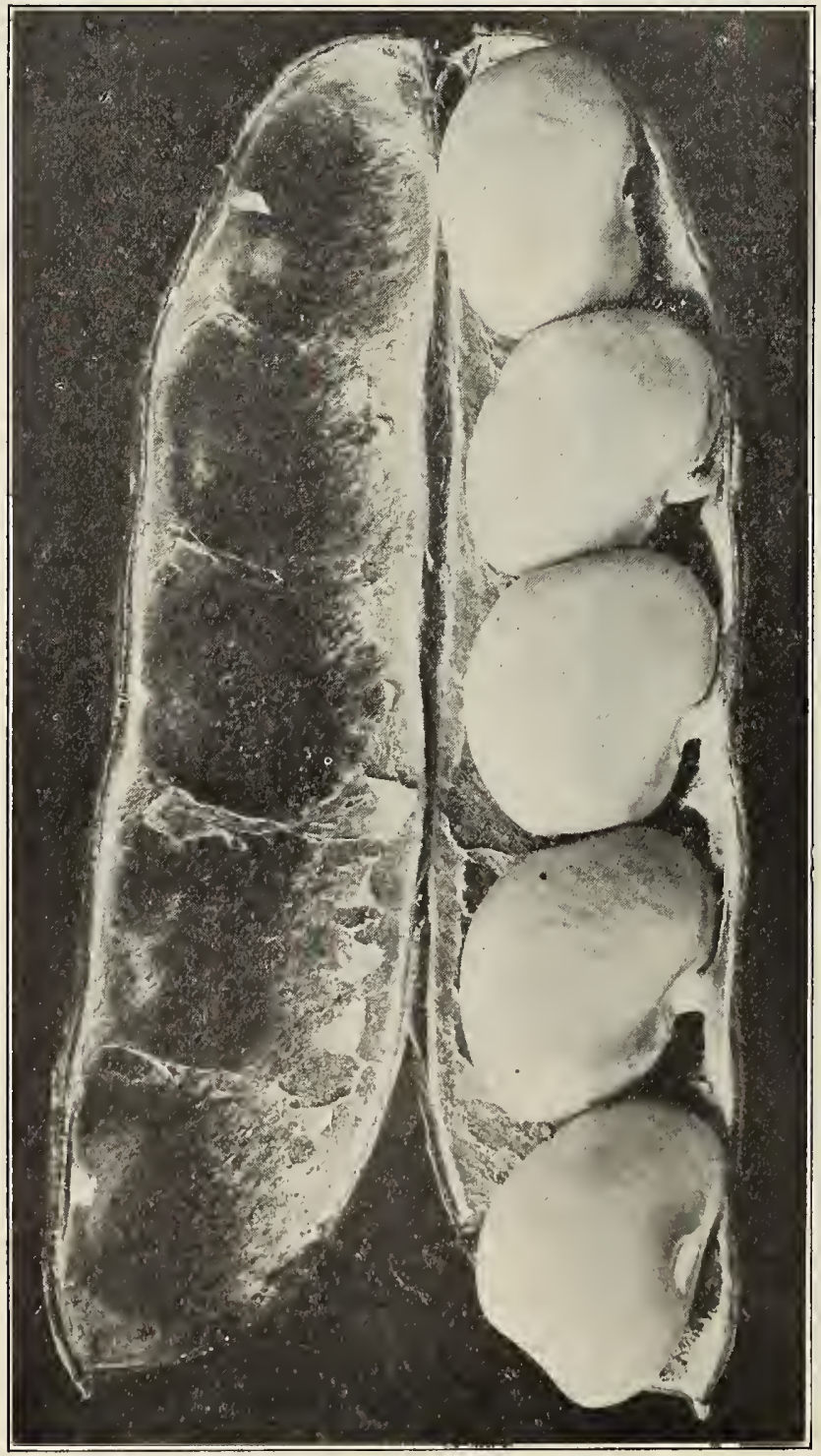

A Life-size Pod of The Burpee Improved Bush Lima.

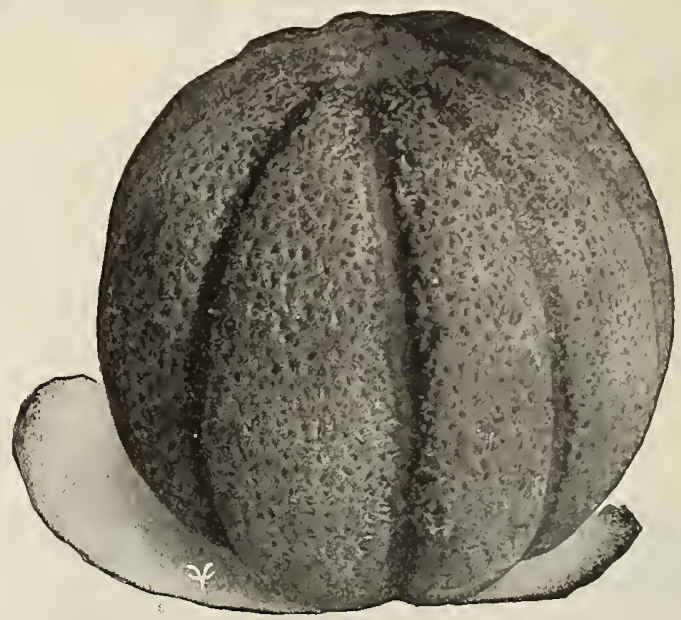

\section{The Burpee Improved Bush Lima Bean}

This is one of the greatest of modern vegetable introductions and we have secured for our customers some seed of it direct from the introducer.

This bean produces magnificent crops of pods, which measure from five to six inches long by one and one-quarter inches wide As compared with the original Burpee Bush Lima, both pods and beans are very much larger, while the beans, either green or dry, are nearly twice as thick. The beans have the same luscious flavor as the best flavored Limas, and are ready to use six to eight days earlier. It will outyield the Burpee Bush Lima by fully one-third, this greater yield being due to the increased size of both pod and beans. The dried beans are very handsome, and generally show a greenish white coloring.

Price: $15 c$ per pkt.; $1 / 4$ Ib. $40 c$; per Ib. $\$ 1.25$

\section{Fordhook Bush Lima}

This bean is of the type of Dreer's Bush Lima, which it most nearly resembles. Its height is from twenty-two to twenty-four inches, and it bears its beans in clusters of two to five, well out from the plant on long spilies. There are from three to five beans in each pod, with an average of four. The beans are round and thick, like those of Dreer's Bush, and have the same mild, delicious flavor. This bean (like the above) is far ahead of any. thing which anybody has known in Lima Beans up to the present time.

Price: $15 c$ per pkt.; $1 / 4$ lb. $40 c$; per lb. $\$ 1.25$ 


\section{Artichoke}

Artichaut

Alcachofa

Artischocke

Articiocea

Artichokes are cultivated for the edible bud, which resembles a ciant thistle. The plants want a very rich soil and plenty of moisture. In California the seed should be planted in boxes in January and the young plants transplanted in March or April. While plants usually bear for five or six years, it is advisable to start new ones from seed occasionally. The suckers from the large plants are also good for transplanting.

* LARGE GREEN GLOBE. The most popular variety. Buds large, globular, deep green, with tint of purple at base. Pkt. 10c; oz. 35c; 1/4 lb. $\$ 1.00 ;$ lb. $\$ 3.50$ : Strong two-year-old roots of this variety, 20c each; JERUSALEM, OR TUBEROUS-ROOTED ARTICHOKE. Entirely distinct, and grown exclusively for their large potato-like roots, which are valuable for feeding hogs, the yield often exceeding two tons per acre. They need not be dug, but the hogs can be turned into the field to root them up; one acre will keep twenty head in good condition until spring. The tubers are also edible, and are delicious when weli cooked.

Per Ib. 15c; 100 lbs, at market rates.

\section{Asparagus}

\section{Asperge \\ Esparrago \\ Sparagio}

It requires three or four years from the time of planting asparagus seeds to the time that the plant produces shoots suitable for eating, and for this reason roots are desirable, as offered below. To raise plants from seed about one pound per acre is required, or one ounce for about 800 plants. When set out for crop, in the field or in beds, they require plenty of room, since the plants spread from the root, and therefore grow larger each year. In the field the rows should be from six to ten feet apart. A loose, porous soil is necessary for good asparagus, and the flavor of the young shoots greatly depends upon the character of the soil. The light, fibrous soils of the Sacramento River Islands seem especially adapted for perfect asparagus.

In the house garden, the soil, if naturally heavy and stiff, must be made porous and light by spading in the proper amount of manure and sand. During the spring all the shoots must be cut as fast as they reach the surface. Later in the season all the shoots should be allowed to run to seed, and in the autumn all the tops should be cut off and burned and the land thoroughly cleaned up and a good dressing of manure and wood ashes and sand should be spaded into the beds.

Barr's Mammoth. A favorite with market gardeners. Shoots very large, tender, quick growing, and thick to the top.

Pkt. $5 c$; oz. 10 c; 1/4 lb. 25c; lb. $85 c$

Columbia Mammoth White. A large, thick variety; very white, even above ground.

Pkt. $5 c$; oz. $10 \mathrm{c} ; 1 / 4$ lb. 25 c; lb. $85 \mathrm{c}$

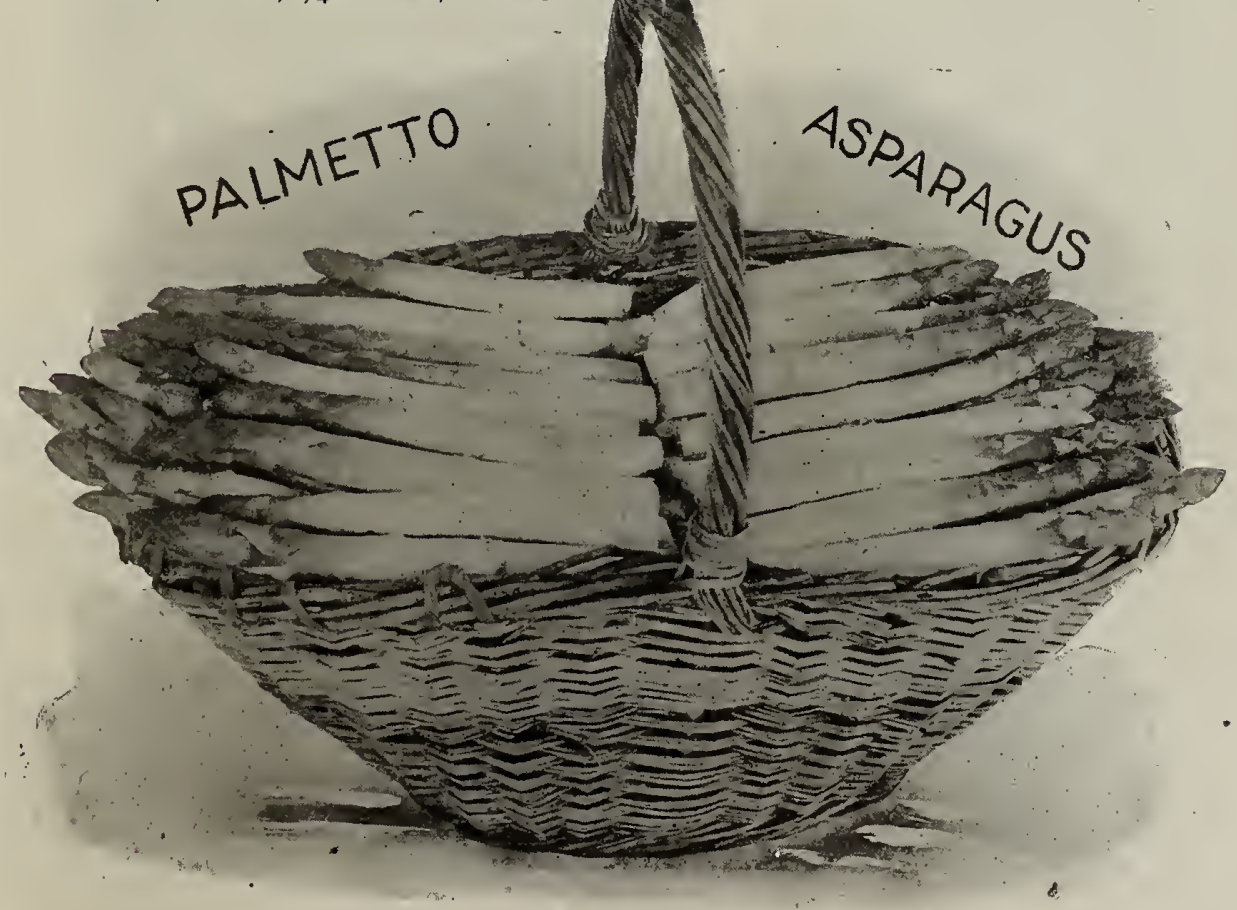

$\$ 2.00$ per doz.

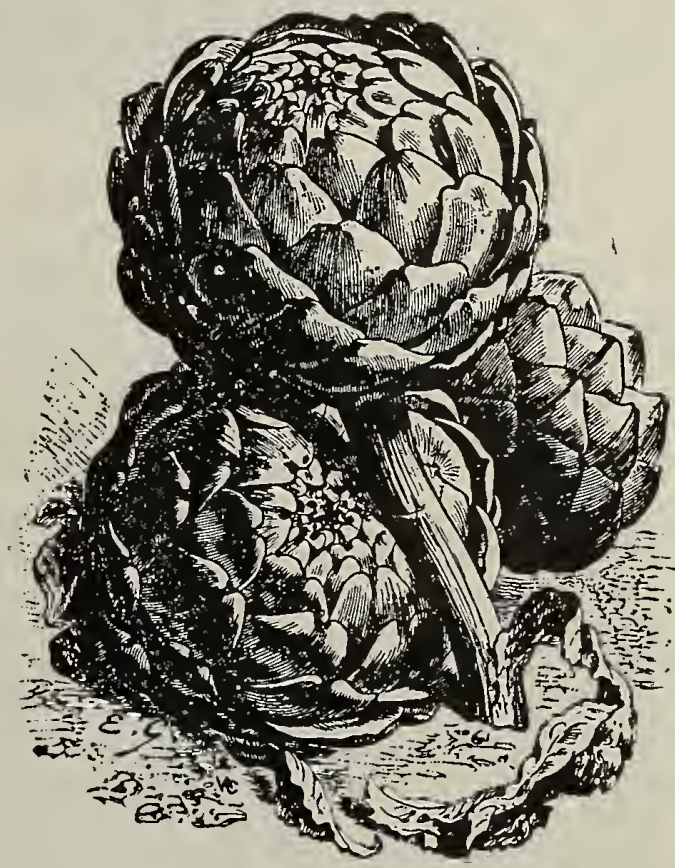

Artichoke.

*CONOVER'S COLOS. SAL OR BOULDIN ISLAND. A standard variety for all purposes, especially for canning. It is the popular variety used on Bouldin Island and other river, points in California, where it is canned in immense quantities. It makes large, thick, white shoots of delicious flavor, and we recommend it as the best variety for all pur poses. Pkt. 5c; oz. 10 c; $1 / 4$ lb. 25 c; lb. 85 c. *PALMETTO. This is the most popular variety grown for general garden purposes, especially for shipping. Shoots are light green and tinted slightly with pink. Pkt. $5 c$; oz. $10 c ; 1 / 4$ lb. $25 \mathrm{c}$; lb. $85 \mathrm{c}$.

Asparagus Roots. Large vigorous roots of the above at $\$ 1.00$ per 100 by freight or express, charges not prepaid. 


\section{Beans}

Haricots
Bohnen

\section{Habichuela}

\section{Faginoli}

Beans are naturally divided into several distinct classes, and each class is represented by a great number of varieties. You will find each class listed here, and we have chosen the best assortment of all varieties.

Beans require a light friable soll, with plenty of molsture, and they are very sensitive to frost. In California

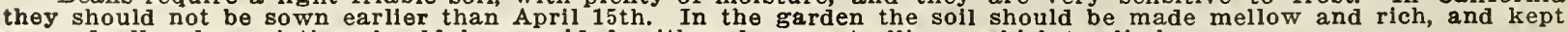
so, and all pole varieties should be provided with poles or a trellis on which to climb.

For farm crop plant about 25 pounds pole beans per acre, in rows 36 inches apart; plant bush beans about 35

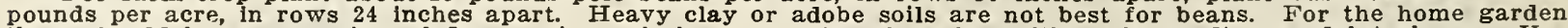

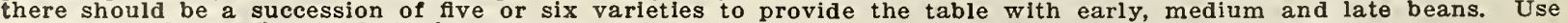
one pound of seed for 100 feet of row.

Express and freight charges are not prepaid. Write us for special quotations if large quantities are wanted.

\section{Dwarf or Bush Beans-Green Podded}

\section{Haricot Nains}

Busch-Bohnen

Frijole nano

In this elass are the dwarf beans having green pods. The newest and best varieties are now absolutely stringless.

Canadian Wonder. A hardy and thrifty variety bearing long green pods of fair quality. The seed is a rich mahogany red and very attractive. Per Ib. 25c, postpaid; or lb. $15 \mathrm{c}$; 10 lbs. $\$ 1.25$; 100 lbs. $\$ 10.00$ by express or freight, charges to be paid by purchaser.

Early Long Yellow Six Weeks. A long podded green variety. Plants strong and vigorous and leaves large; of fair quality. Seed long, kidney-shaped, light-yellow with darker marks about the eyes. Per lb. 25c, postpaid; or by express or freight, lb. 15c; 10 lbs. $\$ 1.00 ; 100$ Ibs. $\$ 8.00$.

Extra Early Refugee. A very early, green-podded variety, with medium-sized, green, fleshy pods; seed drab, freely spotted with dark purple. The vines are smaller and of more upright growth, and leaves a little larger than the Late Refugee. Per Ib. 25c, postpaid; or by express or freight, lb. 15c; 10 lbs. $\$ 1.00$; 100 lbs. $\$ 9.00$.

Extra Early Red Valentine. A popular variety; erect vine with dark-green leaves. Pods of medium length; fleshy, round, and saddle-backed, with only slight strings. Seed pink, marbled with red. Per lb. 25c, postpaid; or by express or freight, lb. 15c; 10 lbs. $\$ 1.00$; 100 lbs. $\$ 8.00$.

Refugee, or 1,000 to 1. A variety rather later than other green-podded varieties. Vines large, spreading, and very hardy; pods long and green, becoming white, streaked with purple as they mature. Seed yellow1sh; heavily splashed with bluish black. Per Ib. $25 \mathrm{c}$, postpaid; or by express or freight, Ib. 15c; 10 lbs. $\$ 1.00 ; 100$ lbs. $\$ 8.00$.

Early Mohawk. A hardy and early variety, with large, flat, dark-green pods with tapering points; seed long, kidney-shaped; drab, purple, and brown. Per lb. 25 c, postpaid; or by express or freight, Ib. 15c; 10 lbs. $\$ 1.10 ; 100$ lbs. $\$ 9.00$.

Dwarf Horticultural. A very vigorous variety with large leaves; used as a shell bean, green or dried. Pods are of medium length, slightly curved, and when, nearly ripe are striped and splashed with crimson on yellowish-brown; seed pale pink, splashed with bright red. Per $1 b .25 c$, postpaid; or by express or freight, lb. $15 \mathrm{c} ; 10$ lbs. $\$ 1.00 ; 100$ lbs. $\$ 9.00$.

English or Broad Windsor. A very well-known and popular variety with many farmers. Familiarly known as the Horse Bean. Per Ib. 25c, postpaid; or by express or freight, lb. 15c; 10 lbs. 70c; 100 lbs. $\$ 6.00$.

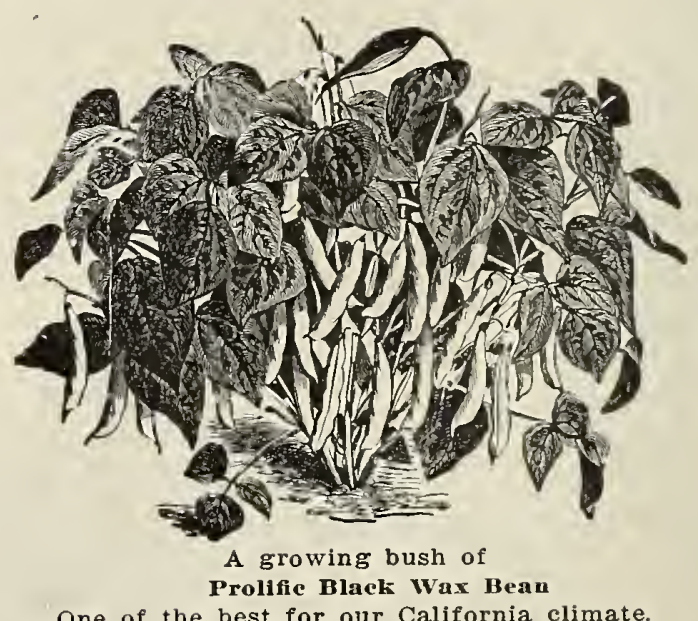

*STRINGLESS GREEN POD. A very valuable greenpodded variety, absolutely free from strings. Is very early; pods are long, rather round, very fleshy and deeply saddle-backed; seed rich seal brown.

Per Ib. 25c, postpaid; or by express or freight, lb. 15 c; 10 lbs. $\$ 1.10 ; 100$ lbs. $\$ 9.00$.

Round Yellow Six Weeks. A large, vigorous, productive bean, with long, straight, flat, light-green pods; seed light-yellow, with marks darker about the eyes.

Per Ib. 25c, postpaid; or by express or freight, lb. 15 c; 10 lbs. 90 c; 100 lbs. $\$ 8.50$.

French String Bean. A hardy green-podded variety, with black seed. Is much esteemed by the Italian - market-gardeners for a very productive string bean and a good shipper. Per Ib. 25c, postpaid; or by express or freight, Ib. $15 \mathrm{c} ; 10 \mathrm{lbs} .90 \mathrm{c} ; 100 \mathrm{lbs}$. $\$ 8.50$. 


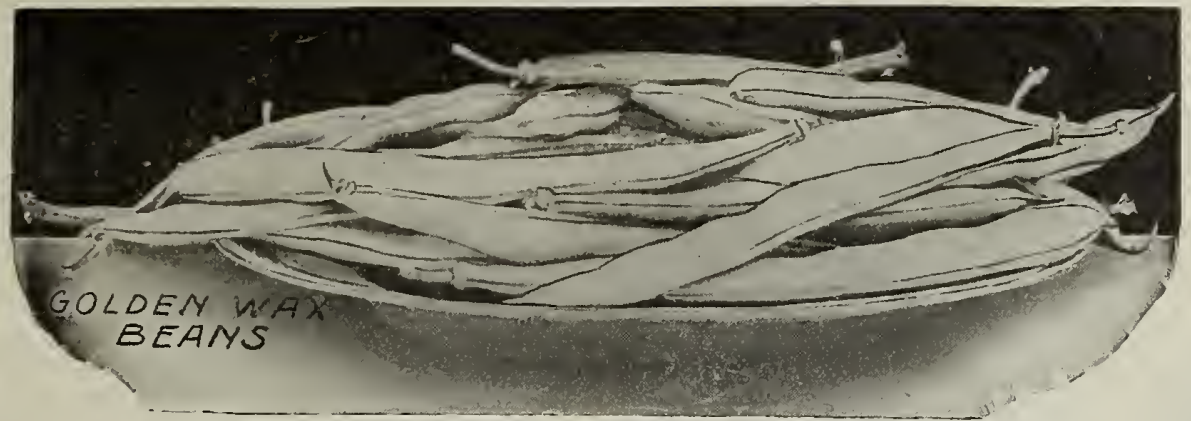

\section{Dwarf or Bush Beans-Wax Podded}

In thls elass are the dwarf beans, having creamy white, yellow, aud golden-yellow pods. Most of the varietlew we list are stringlew.

Davis White Wax. The most hardy and productive waxpodded variety. The pods are very long and yellow; and while not stringless, it is a remarkably good bean for shipping; seed, white, and on this account is desirable for a shelled bean in winter. Per Ib. 30c, postpaid; or by express or freight, Ib. 20c; 10 lbs. $\$ 1.25 ; 100$ lbs. $\$ 10.00$.

*GOLDEN WAX. One of the most popular garden varieties in cultivation. Pods are long, nearly straight, broad, and flat, and golden yellow; seed white, more or less covered with two shades of purplish red. Per Ib. 25c, postpaid; or by express or freight, Ib. $15 \mathrm{c} ; 10$ lbs. $\$ 1.25 ; 100$ lbs. $\$ 9.00$.
Improved Rust-Proof Golden Wax. (Grennell's.) Rather hardier than Golden Wax, and the pods are broader and flatter; seed white, somewhat spotted with purplish red. Per lb. 25c, postpaid; or by express or freight, Ib. $15 \mathrm{c} ; 10$ lbs. $\$ 1.25 ; 100$ lbs. $\$ 10.00$.

Pencil Pod Wax. This is the best black wax bean in cultivation. The pods are long, thick, and meaty; and deeply saddle-backed, and entirely stringless. The plant is strictly a bush, growing about fifteen inches high. Seed black. Per lb. $30 \mathrm{c}$, postpaid; or by express or freight, Ib. $20 \mathrm{c} ; 10$ lbs. $\$ 1.75 ; 100$ lbs. $\$ 15.00$.

*PROLIFIC BLACK WAX. An improvement on the old Black Wax or Butter Bean. Very vigorous and prolific; pods fairly long, golden yellow, very brittle, and stringless; seed black. Per Ib. $25 \mathrm{c}$, postpaid; or by express or freight, 1 lb. $15 \mathrm{c} ; 10$ lbs. $\$ 1.10 ; 100$ lbs. $\$ 9.00$.

*WARDWELL'S KIDNEY WAX. A strong growing vine, fifteen inches in hight. A little later than Golden Wax; pods long, broad, golden yellow, brittle, and entirely stringless; seed white with dark markings about the eye. Market gardeners find this bean one of the most profitable. Per lb. 25c, postpaid; or by express or freight, Ib. $20 \mathrm{c} ; 10$ lbs. $\$ 1.25 ; 100$ lbs. $\$ 10.00$.

\section{Pole or Running Beans-Green and Wax=Podded}

\section{Haricots a Rames Stangenbohnen Frijole Vastaga}

These beans require a pole or trellis to climb on, 11 planted in the garden, although when raised as a seed crop in the open field they need no support whatever. Pole beans are usually very prolific, and bear longer pods and a great many more of them than the bush varieties.

Burger's Pole. A new pole variety of great merit. Bears long, brittle, stringless pods of excellent flavor. It rivals all other pole beans and is destined to become the most popular of all.

Per Ib. 30c, postpaid; or by express or freight, Ib. 20c; 10 lbs. $\$ 1.50$.

Cut Short, or Corn Hill. A popular variety for planting among corn, since the vines climb the corn-stalks without the use of poles. Pods short and green; leaves deep green; seed white, spotted freely with reddish brown. Per lb. 25 c, postpaid; or by express or freight, lb. $15 c ; 10$ lbs. $85 c ; 100$ lbs. $\$ 7.50$.

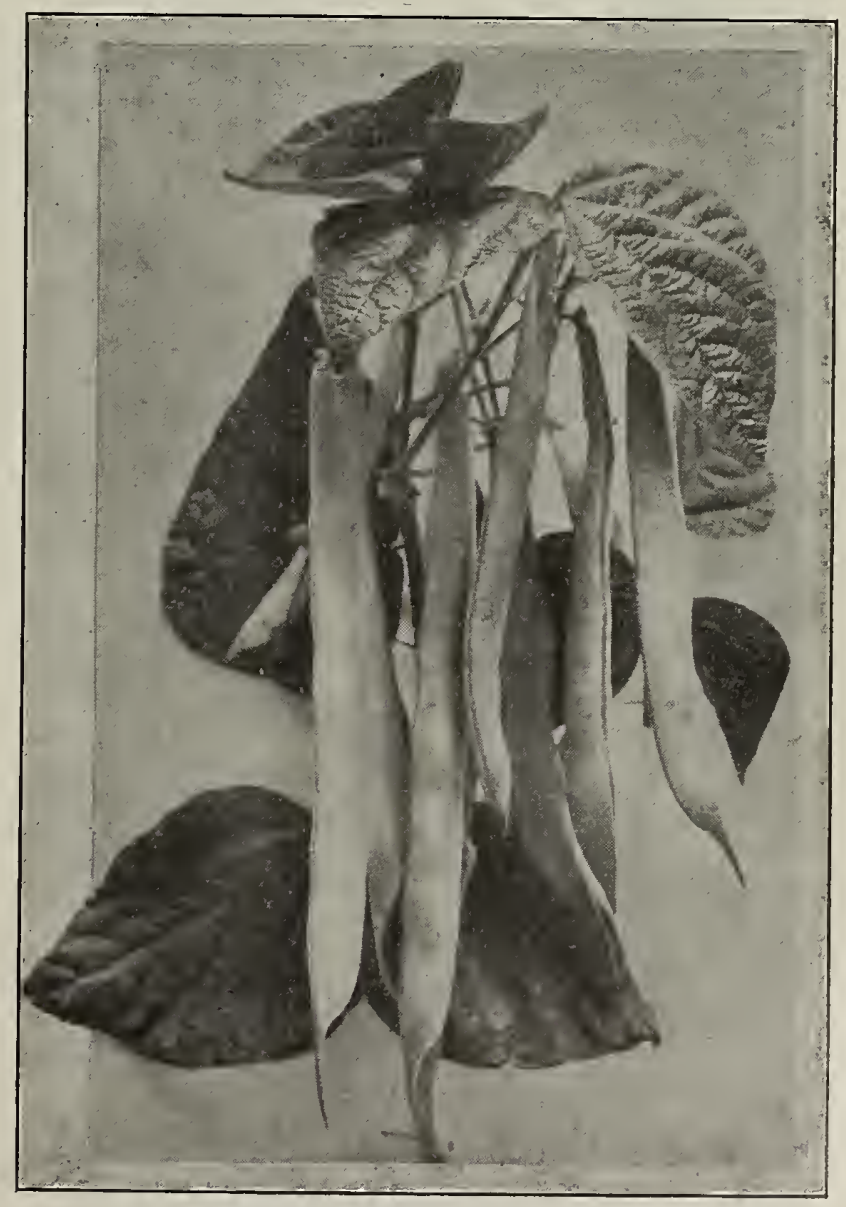

Davil White Wax.

One of the best shipping varietles for market gardeners. 


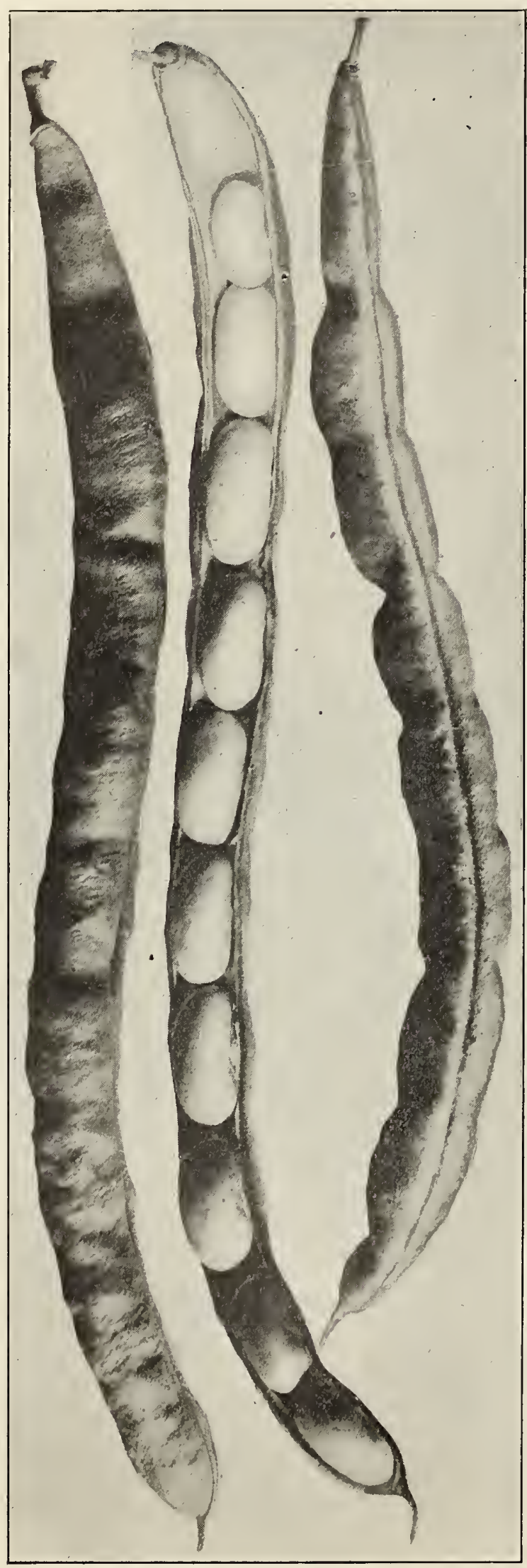

KENTCCKY WONDER HEAN Life-size average pods. Brittle, stringless, meaty, delicious flavor.
POLE BEANS-GREEN AND WAX-PODDED-Continued

*EARLY GOLDEN CLUSTER WAX. A very popular, early, and fine variety; pods six to eight inches long, wide and flat, borne in clusters, each containing from three to six pods, which are golden yellow. The pods are of fine quality and remain in condition to use for a long time; seed flat and dull white. Per lb. 30c, postpaid; or by express or freight, lb. 20c; 10 lbs. $\$ 1.50 ; 100$ lbs. $\$ 12.00$.

Horticultural or Speckled Cranberry. An old favorite. Pods short, pale green, becoming splashed with brownish red. Seed blush pink, spotted with red. Valuable either green or dry shelled. Per Ib. 25c, postpaid; by express or freight, lb. 15c; 10 lbs. 90c; 100 lbs. $\$ 8.00$.

*KENTUCKY WONDER OR OLD HOMESTEAD. The most popular of the pole varieties, and should be in every garden where beans are planted. It grows luxuriantly and bears for a long period. Pods are very long, very fleshy, and deeply creased or saddlebacked, green in color, and stringless. Seed light brown. Per lb. 25c, postpaid; by express or freight, lb. 15 c; 10 lbs. $\$ 1.10 ; 100$ lbs. $\$ 9.00$.

Indian Chief or Tall Black Wax. A black-seeded wax variety with thick, golden-yellow pods. Very hardy and prolific, and the most popular of the pole wax beans. Per lb. 25c, postpaid; by express or freight, lb. $15 \mathrm{c}$; 10 lbs. $90 \mathrm{c}$; 100 lbs. $\$ 10.00$.

Kentucky Wonder Wax. An excellent variety, and one of the very best pole beans. The pods are long, very thick, meaty, deeply saddled-backed, entirely stringless, and bright yellow in color. The vine is thrifty and very prolific. Seed deep brown. Per Ib. 30c, postpaid; by express or freight, lb. $20 \mathrm{c} ; 10 \mathrm{lbs} . \$ 1.50$.

Lazy Wife. A green-podded variety bearing good, long pods in clusters; stringless and of peculiarly fine flavor; seed rather large, thick and white. Per lb. 25c, postpaid; by express or freight, Ib. 15c; 10 lbs. $\$ 1.00 ; 100$ lbs. $\$ 9.00$.

Scarlet Runner. The well-linown and old-fashioned climber, having bright scarlet, pea-like flowers. It not only holds it splace as a flower, but the pods when young are of fine quality for cooking. Seed large, bright scarlet, heavily blotched with purple. Pkt. 10c; lb. 35c, postpaid; by express or freight, Ib. $25 \mathrm{c}$.

Southern Prolific. A very popular, green-podded variety, bearing its pods in clusters; seed light yellowishbrown. Pkt. 10c; lb. 25c, postpaid; by express or freight, Ib. $15 \mathrm{c} ; 10 \mathrm{lbs} .90 \mathrm{c} ; 100 \mathrm{lbs}$. $\$ 8.50$.

White Creaseback. An early, green-podded variety. Pods five to six inches in length, deeply creased or saddlebacked, and borne in clusters. Are very fleshy and stringless; seed white and can be used as a shelled bean for winter use. Per Ib. 25 c, postpaid; by express or freight, lb. $15 \mathrm{c} ; 10 \mathrm{lbs} . \$ 1.10 ; 100 \mathrm{lbs}$. $\$ 9.00$.

White Dutch Case Knife. A climbing variety with long, flat, irregular pods, which become creamy white as they mature; seed broad, flat and clear white. Per Ib. $25 \mathrm{c}$, postpaid; by express or freight, lb. 15c; 10 lbs. $\$ 1.10 ; 100$ lbs. $\$ 9.00$. 


\section{Beans-Lima Varieties}

Lima beans are delicious when used green shelled, and can be grown for this purpose in any climate. The dry ripened bean is also a staple article of food for winter use, but in California these beans ripen only from San Luis obispo County and south to Pasadena. The best territory for seed beans we believe to be Santa Barbara and San Buenaventura counties, where we grow our stock.

Burpee Improved Bush.-See page 2.

*BURPEE'S BUSH. The best late dwarf variety. Plant eighteen to twenty-four inches high; very prolific. Pods large, and the beans also large and heavily ribbed. Will bear until stopped by frost. Pkt. 10c; lb. 25 c, postpaid; by express or freight, Ib. $15 \mathrm{c} ; 10$ lbs. $\$ 1.25 ; 100$ lbs. $\$ 10.00$.

Dreer's Bush or Kumerle. A very prolific variety, a little later than Burpee's and having short thick pods, closely filled with short, almost round, seed. "The plant does not grow upright, but spreads or trails over the ground about three feet in diameter. Pkt. $10 \mathrm{c}$; Ib. 25c, postpaid; by express or freight, Ib. 15c; 10 lbs. $\$ 1.25 ; 100$ lbs. $\$ 10.00$.

*EARLY LEVIATHAN. One of the newer varieties and the very best pole variety in cultivation. Vine very tall and strong; pods long and borne in clusters; beans large and white. Is early, strong-growing and prolific. Pkt. 10c; lb. $30 \mathrm{c}$, postpaid; by express or freight, Ib. $20 \mathrm{c} ; 10$ lbs. $\$ 1.50 ; 100$ lbs. $\$ 12.50$.

Fordhook Bush.-See page 2.

Henderson's Bush. The earliest variety we have, being fully two weeks earlier than any other variety. Plant about sixteen inches high and very prolific.

Beans are small. Especially recommended where the season is short. Pkt. 10c; lb. 25c, postpaid; by express or freight, lb. $15 \mathrm{c} ; 10$ lbs. $\$ 1.25 ; 100$ lbs. $\$ 10.00$.

Challenger, or Dreer's Pole. A splendid pole variety, quite early, very prolific, and of very fine quality. The pods are borne in clusters, and the beans are short and thick, almost round, and crowded so closely in the pod that the ends are flattened. A very popular variety with market gardeners. Pkt. 10c; lb. 25c, postpaid; by express or freight, lb. $15 \mathrm{c} ; 10 \mathrm{lbs}$. $\$ 1.25$; 100 lbs. $\$ 10.00$.

King of the Garden. One of the best and most popular main crop varieties. It is medium early and has very long pods, $51 / 2$ to $61 / 2$ inches long, which are well filled with four or five good-sized beans. The pods are very straight and handsome, and the fine, hardy vines bear abundantly. Pkt. 10c; lb. 25c, postpaid; by express or freight, lb. $15 \mathrm{c} ; 10$ lbs. $\$ 1.25$; 100 lbs. $\$ 10.00$.

Large White. A very good variety of the pole or running type. Is very prolific and of good quality, but is now being superseded by Early Leviathan. Pkt. 10c; lb. 25c, postpaid; by express or freight, Ib. 15c; 10 lbs. $\$ 1.00 ; 100$ lbs. $\$ 8.00$.

\section{Beets}

Betterave

Beets are divided into three cla

in Caifornia any time ofter January 1st, and and SCGAR. crisp, tender flesh.

\section{TABLE VARIETIES}

*CROSBY'S EGYPTIAN. More globe-shaped than Extra Early Egyptian, and the best known and most popular variety; is very early and of fine quality. Bright red with clear vermilion flesh.

Per oz. $10 \mathrm{c} ; 1 / 4$ lb. $20 \mathrm{c}$; Ib. $60 \mathrm{c}$

*DETROIT DARK RED. One of the best table varieties, and the one we recommend for all garden purposes. Globe-shaped; bright, but rich red flesh. Tops small and green.

Per oz. $10 \mathrm{c} ; \mathrm{l} / 4 \mathrm{lb} .20 \mathrm{c}$; lb. $60 \mathrm{c}$

Early Eclipse. A fine, early table variety, top-shaped or tapering globe-shaped. Flesh deep crimson, zoned with lighter red. Crisp and sweet.

Per oz. $10 c ; 1 / 4$ lb. $20 c$; Ib. $60 c$

Edmand's Blood Turnip. Roots globular and tapering, or more correctly top-shaped. Flesh deep blood-red, scarcely showing the zones. Leaf green.

Per oz. $10 \mathrm{c} ; 1 / 4$ Ib. $20 \mathrm{c}$; Ib. $60 \mathrm{c}$

Extra Early Blood Turnip. A good variety for summer and autumn use. Is turnip-shaped with bright red flesh showing zones. Per oz. 10c; 1/4 lb. 25c; lb. $75 \mathrm{c}$

Half Long Blood. A half-long variety about eight inches long and tapering abruptly. Very rich, deep red flesh of fine quality. Per oz. $10 \mathrm{c} ; 1 / 4 \mathrm{lb} .20 \mathrm{c} ; \mathrm{lb} .60 \mathrm{c}$

Extra Early Egyptian. A turnip-shaped variety with dark-red flesh showing zones of a lighter shade. Dark leaves; a good table variety and very early.

Per oz. $10 \mathrm{c} ; 1 / 4 \mathrm{lb} .20 \mathrm{c} ; \mathrm{lb} .60 \mathrm{c}$

CROSBY's

EGYPTIAN

$B E E T$

*LONG SMOOTH DARK BLOOD. A very desirable variety for light soils, where roots are easy to dig. Skin very dark brơwnish-red. Flesh deep blood-red. Per oz. $10 \mathrm{c} ; 1 / 4$ Ib. $20 \mathrm{c}$; Ib. $60 \mathrm{c}$

*MORSE'S IMPROVED BLOOD TURNIP. A turnipshaped variety, with deep red flesh. Tops green. A fine selected strain and one of the best varieties. Per oz. $10 \mathrm{c} ; 1 / 4$ Ib. $20 \mathrm{c} ; \mathrm{lb} .60 \mathrm{c}$ 


\section{BEETS-Continued}

MANGEL WURZEL, OR STOCK-FEEDING

For main crop, sow about March 1 st in rows 22 inches apart using about six pounds of seed per acre. To get good, large and uniform beets, the plants should be thinned when in the fourth leaf to six inches apart in the row.

If large lots of seed are wanted, write us for special prices.

Champion Yellow Globe. A large, round, orange-yellow variety. Good for shallow soils. Per lb. 35c, postpaid; or by freight or express, Ib. 25c; 10 Ibs. $\$ 200$; 100 lbs. $\$ 16.00$.

Giant Yellow Intermediate or Gate Post. A yellowskinned variety with white flesh, zoned with yellow. Large and ovoid shape. Per lb. 35c, postpaid; or by freight or express, lb. 25c; 10 lbs. \$2.00; 100 lbs. $\$ 16.00$.

*GOLDEN TANKARD YELLOW-FLESHED. Very large, yellow-fleshed variety. Giant oval shape; small yellow-stemmed top. Per lb. 35c, postpaid; or by freight or express, Ib. $30 \mathrm{c}$; 10 lbs. $\$ 2.50$; 100 lbs. $\$ 20.00$.

* MAMMOTH LONG RED. The largest of all the mangels and the heaviest cropper. Skin is red; flesh white, zoned with red. This variety produces a larger amount of good feed than any other beet, and is recommended as superior to all others. Per Ib. 35c, postpaid; or by freight or express, Ib. $25 \mathrm{c}$; 10 lbs. $\$ 2.00 ; 100$ lbs. $\$ 16.00$.

Red Globe. A large globe-shaped variety with red skin. Flesh white, zoned with pink. Per lb. 35c, postpaid; or by freight or express, Ib. $25 \mathrm{c} ; 10$ lbs. $\$ 2.00 ; 100$ Ibs. $\$ 18.00$.

Yelow Leviathan. A large yellow olive-shaped variety, with clear white brittle flesh. The root grows partly out of ground, rendering it easy to dig. Per Ib. $35 \mathrm{c}$, postpaid; or by freight or express, Ib. $25 \mathrm{c}$; 10 lbs. $\$ 2.00 ; 100$ lbs. $\$ 18.00$.

\section{SUGAR BEETS}

Giant Half Sugar for Stock-Feeding. A beet which is superior to mangels for stock-feeding purposes, as it is more nutritious, having a large amount of sugar. It is oval in shape and grows partly out of ground. Is of large size, and yields enormous crops. Per Ib. 35 c, postpaid; or by freight or express, Ib. 25c; 10 lbs. $\$ 2.00 ; 100$ lbs. $\$ 16.00$.

Klein Wanzeleben Sugar. The most popular variety for sugar factories. The value of the strain and the sugar content depends on intelligent care and development on the part of the seed grower. It is wedge-shaped, wide at the top and tapering gradually to a long tail. Per lb. 35c, postpaid; or by freight or express, lb. 25c; 19 lbs. $\$ 2.00$; 100 lbs. $\$ 16.00$.

Lane's Improved Imperial Sugar. Large, thick, tapering variety. Yields almost as much as mangels. Is sweet and rich and very desirable for stock. Per lb. $35 c$, postpaid; or by freight or express, lb. 25c; 10 lbs. $\$ 2.00$; 100 lbs. $\$ 16.00$.

Vilmorin's Improved Sugar. A little smaller than Klein Wanzleben, but even richer in sugar and a valuable variety for sugar factories. Grows entirely under ground, and yields good crops under ordinary conditions. Per lb. $35 \mathrm{c}$, postpaid; or by freight or express, lb. 25c; 10 lbs. $\$ 2.00 ; 100$ lbs. $\$ 16.00$.

*JAENSCH'S VICTRIX. A comparatively new variety and one of the most highly bred and rich sugar varieties we have. Especially recommended to sugar producers. Per Ib. 40c, postpaid; by express or freight, Ib. $30 \mathrm{c} ; 10$ lbs. $\$ 2.50$.

*WHITE SUGAR RED TOP. A very hardy variety, producing large crops with little care. The root is large and very rich in sugar, and while not sufficiently so for sugar purposes, it makes a remarkably fine, rich food for stock. Per lb. 35c, postpaid; by freight or express, Ib. 25 c; 10 lbs. $\$ 2.00 ; 100$ lbs. $\$ 16.00$.

\section{SWISS CHARD, OR SEA KALE, BEET}

Used for greens by cutting the stem and leaf, which ire also very ornamental. It resembles an ornamental beet top, but has no edible root.

Pkt. $5 c$; oz. $10 \mathrm{c} ; 1 / 4$ Ib. 20c; Ib. 60c.

\section{Chou Brocoli}

\section{Broccoli}

Should be treated the same as cauliflower, which it resembles. In fact, it is practically a coarse cauliflower, more divided in the head, grows larger and taller, and is hardier and easier to grow. Plant and cultivate the same as winter cabbage or kale.

*EARLY LARGE WHITE. The best variety. Heads Purple Cape. Good, large heads, which are tinged with white and large. Pkt. $5 \mathrm{c} ;$ oz. $40 \mathrm{c} ; \mathrm{I} / 4 \mathrm{lb} . \$ 1.25 ; \mathrm{lb} . \$ 4.00$ purple.

Pkt. $5 \mathrm{c}$; oz. $35 \mathrm{c} ; \mathrm{1} / 4$ Ib. $\$ 1.00 ;$ Ib. $\$ 3.50$

\section{Brussels Sprouts \\ Rosen-Kohl \\ Berza de Brusels}

\section{Chou de Bruxelles}

\section{Cavoli de Brusselles}

The plants are very hardy and grow from two to three feet high, bearing a large mass of leaves at the top. The sides of the main stem are covered with three or four dozen small cabbage heads, which are broken off and cooked the same as cabbage.

*IMPROVED HALF DWARF. The standard variety. Grows two or three feet high, and the stem is well covered with small, firm, round sprouts.

Pkt. 5c; oz. $15 \mathrm{c} ; \mathrm{1} / 4$ lb. $45 \mathrm{c} ; \mathrm{lb} . \$ 1.50$

\section{Cabbage}

Chou pomme

Col rapollo

Cavollo cappuccio

It is difficult to give definite cultural directions for cabbage, since it is possible to have good cabbage at all seasons of the year in some part of the country, and seed can be planted almost any time of the year. There are three good seasons for sowing the seed, however-in September for early spring cabbages, in March for summer and fall cabbages, and in June or July for winter cabbages. The seed sprouts quickly, and is likely to come up very thick in the seed bed. It should be thinned early, or the plants become spindly, and then do not head well. Transplanted to the field, they should be put twelve inches apart, in rows elghteen inches apart. To prevent the heads spliting open in the field before they are ready to be harvested, the plants should be loosened a little at the root. Cabbages require considerable moisture, but too much water causes them to rot very readily.

\section{EARLIEST VARIETIES.}

Early Baseball. One of the earliest varieties. Forms tight, solid, perfectly globular heads of rather small size.
*EARLY JERSEY WAKEFIELD. One of the best and most popular early varieties. Forms round, pointed heads of good size. Is very hardy and on account 
of its thick outside leaves is able to resist cold and other unfavorable conditions to a great extent.

Pkt. 5c; oz. 20c; $1 / 4$ lb. 60c; Ib. $\$ 2.00$

Extra Early Etampes. One of the earliest varieties, producing light-green pointed heads.

Pkt. $5 c$; oz. 20c; 1/4 lb. 60 c; lb. $\$ 2.00$

Extra Early Express. Very early, producing firm, round heads. A little earlier than Wakefield, and a good variety for shipping.

Pkt. $5 c$; oz. 20 c; $1 / 4$ lb. 60 c; lb. $\$ 2.00$

*EARLY WINNIGSTADT. A decidedly pointed head of good size and fine quality - the most sharply pointed of all cabbages. Is one of the hardiest varieties, and resists cold, wet and insect pests to a degree which makes it very desirable, and we recommend it as one of the best early varieties.

Pkt. $5 c$; oz. 20 c; $1 / 4$ lb. 60 c; lb. $\$ 2.00$

Early Spring. A very early flat-headed variety. Medium sized and good for summer use.

Pkt. $5 c$; oz. 25 c; $1 / 4$ lb. $75 c$; Ib. $\$ 2.50$

Glory of Enkhuizen. A fine variety which forms uniformly fine, solid, globe-shaped heads. A very good variety for the home garden.

Pkt. $5 \mathrm{c} ;$ oz. $30 \mathrm{c} ; 1 / 4$ lb. $90 \mathrm{c} ;$ Ib. $\$ 3.00$

Large Early Wakefield (Charleston). Is very similar to Early Jersey Wakefield, but nearly a third larger and a little later. Pkt. $5 \mathrm{c} ;$ oz. $40 ; 1 / 4 \quad$ lb. $60 \mathrm{c} ; \mathrm{lb} . \$ 2.00$

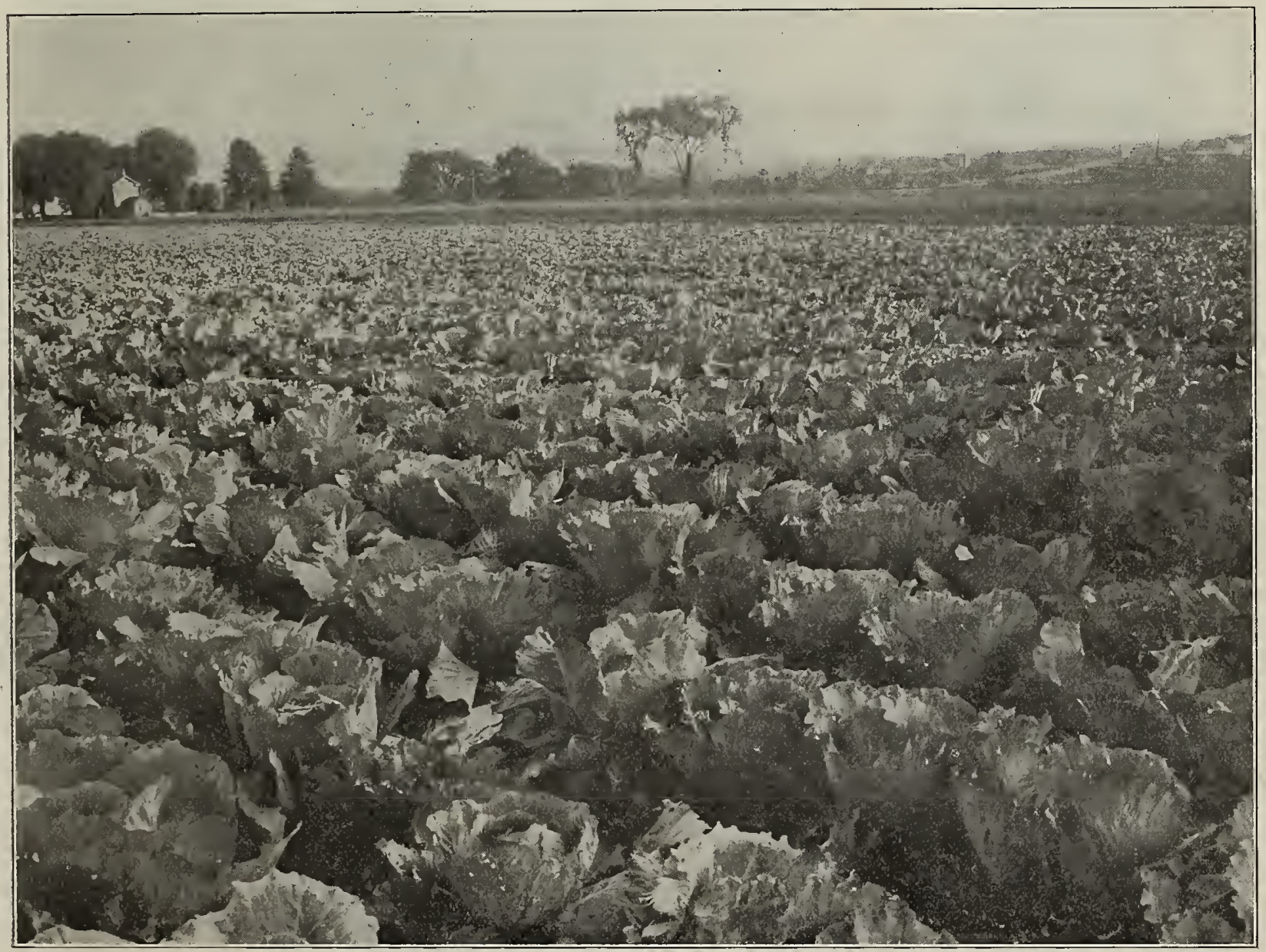

A fine fleld of marketable Early Jersey Wakefield Cabbages.

\section{EARLY AND SECOND}

*ALLHEAd EARLY. Probably the earliest of the large, flat-headed varieties. Is good for summer, autumn, and winter crop. Desirable for all sorts of planting.

Pkt. $5 c$; oz. 20 c; $1 / 4$ lb. 60 c; lb. $\$ 2.00$

All Seasons. One of the best second early varieties. Large, round, flattish heads. Dark green. Not only good summer variety, as it withstands heat well, but valuable as a fall and winter variety, hence its name.

Pkt. 5c; oz. 20c; 1/4 lb. 60 c; lb. $\$ 2.00$

*EARLY DRUMHEAD. Second early; round, flat heads.

Pkt. 5c; oz. $15 \mathrm{c} ; 1 / 4$ Ib. $60 \mathrm{c}$; Ib. $\$ 2.00$

Early Dwarf Flat Dutch. A good flat-headed variety,

\section{EARLY VARIETIES.}

with short stem and hard, firm head. Forms heads early and is valuable for summer.

Pkt. 5c; oz. 20c; 1/4 lb. 60c; lb. $\$ 1.75$

Fottler's Brunswick. One of the most popular of the flatheaded types, especially with the home gardener. Best for autumn and winter use.

Pkt. $5 c ;$ oz. 20 c; $1 / 4$ Ib. 60 c; Ib. $\$ 2.00$

Henderson's Early Summer. A desirable medium sized, early, flat-headed variety. A good keeper, and does well in summer and autumn.

Pkt. $5 c ;$ oz. 20 c; 1/4 Ib. 60 c; lb. $\$ 2.00$ 
CABBAGE-Continued

Henderson's Succession. Is about ten days later than Early Summer. Is a dwarf, flat head, light green, and very solid. Pkt. $5 \mathrm{c} ;$ oz. $20 \mathrm{c} ; \mathrm{1} / 4$ lb. $60 \mathrm{c} ; \mathrm{lb} . \$ 2.00$

*MORSE'S SELECTED EARLY FLAT DUTCH. A very superior strain of this variety. An early hard-heading cabbage of bright turquoise green.

Pkt. $5 c$; oz. $25 c ; 1 / 4$ Ib. $75 c ;$ Ib. $\$ 2.50$

\section{WINTER VARIETIES}

Autumn King, or Worldbeater. A fine winter variety of vigorous growth. Large, well-formed globular heads of bluish green. Pkt. $5 \mathrm{c} ;$ oz. $25 \mathrm{c} ; 1 / 4 \mathrm{lb} .75 \mathrm{c} ; \mathrm{lb} . \$ 2.50$

Burpee's Surehead. One of the most popular varieties. Large, round, slightly flattened head; hard and firm.

Pkt. $5 c ;$ oz. $20 c ; 1 / 4$ lb. 60 c; lb. $\$ 2.00$

Danish Ball Head, or The Hollander. A very late variety, forming globular heads; very hard and solid. Keeps well and is a good shipper. The color is bluish-green. Pkt. $5 \mathrm{c}$; oz. $25 \mathrm{c} ; \mathrm{l} / 4$ lb. $75 \mathrm{c} ; \mathrm{lb}$. $\$ 2.50$

*PREMIUM FLAT DUTCH. A well-known, large, late variety. Flattish, round heads, very solid and firm; has rather tall, stout stem.

Pkt. $5 c$; oz. 20c; 1/4 Ib. 60c; Ib. $\$ 2.00$

Stone-Mason Marblehead. Medium-sized, late, flat-headed variety, forming a good, solid head. The leaves are bright green, with conspicuous veins.

Pkt. $5 c ; 0 z .20 c ; 1 / 4$ Ib. $60 c$; lb. $\$ 2.00$

\section{RED CABBAGE}

Mammoth Rock Red. Best hard-headed, red variety. Large heads, globular, and very deep red on top. Outer leaves greenish. Especially used for pickling. Pkt. $5 c$; oz. 20 c; $1 / 4$ lb. 60 c; lb. $\$ 2.00$

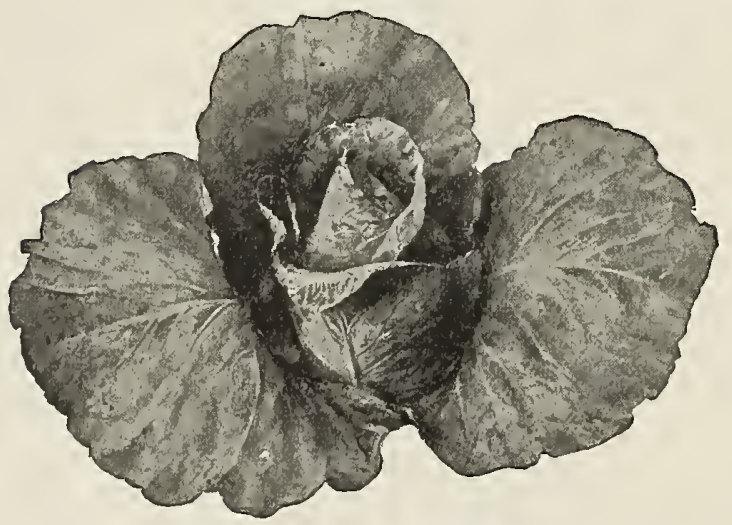

Early Winnigutadt Cabbage

\section{CABBAGE-SAVOY}

Perfection Drumhead Savoy. A variety that is much prized in Europe and also by those who are familiar with it in this country. It is very sweet and crisp, and always tender. Heads medium sized and fairly compact. $\quad$ Pkt. $5 \mathrm{c} ;$ oz. $20 \mathrm{c} ; 1 / 4$ lb. $60 \mathrm{c} ; \mathrm{Ib} . \$ 2.00$
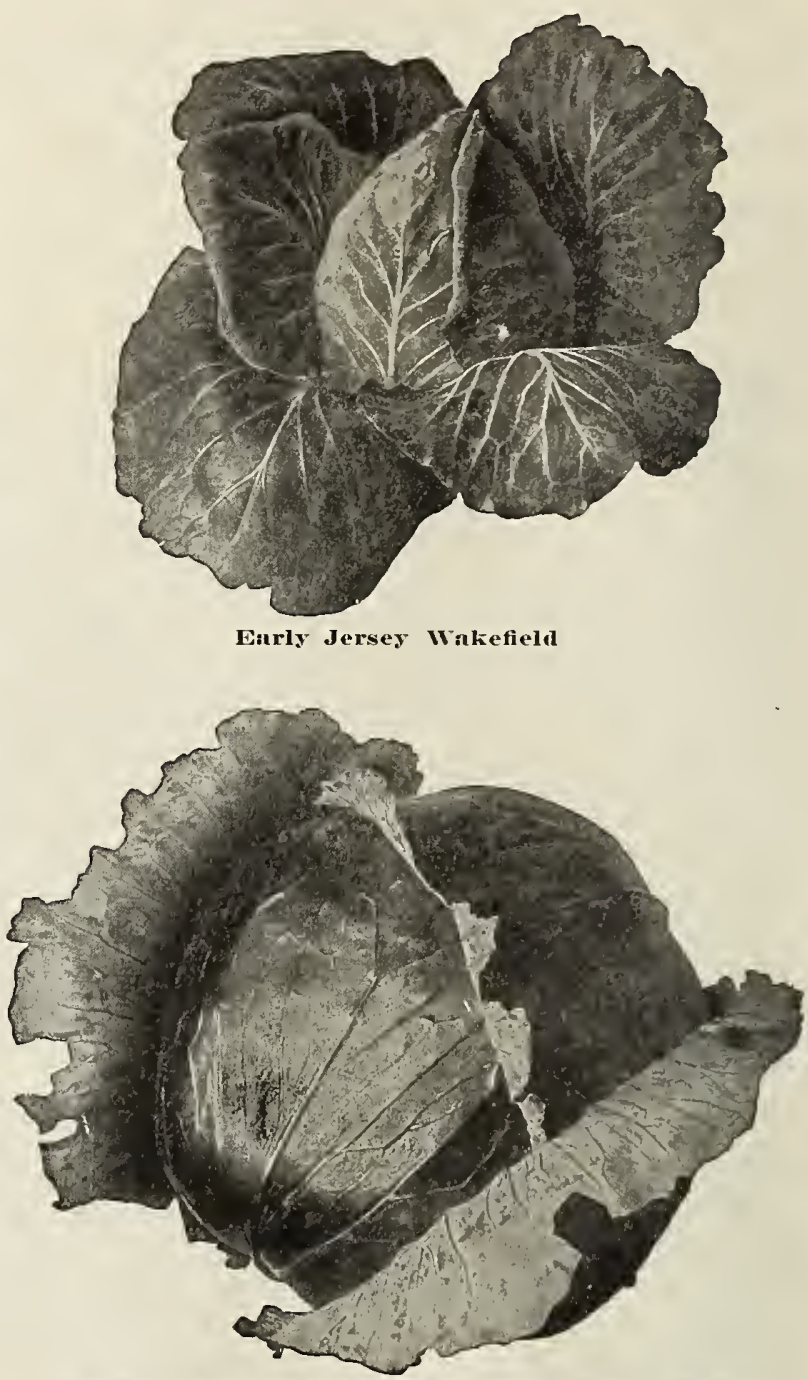

Morse's Selceted Strain Early Flat Dutch Cabbage

CHIVES. A plant resembling a tuft of grass, but the leaves have the flavor of onions. The leaves are used in Soups and Salads, giving a mild onion flavor to same.

Pkt. 10c, oz. 50c

\section{Casaba Melon--the New Winter Muskmelon}

This is really a great acquisition to the vegetable world and is destined to become a standard vegetable just as much so as potatoes or onions. The seed should be sown late in the spring, after all danger of frost is over on moist sandy loam. Do not pick until the light streaks become quite yellow. Stow away so they do not touch each other in a cool, dark place. When the rind becomes slightly softened and moist they are ready to eat. Some of the melons will actually keep until February.

The seed cavity is small and the flesh thick of fine texture and juicy and palatable to within one-quarter inch of the skin. The flavor is delicious-almost impossible to describe to do it full justice. There is a decided flavor of pineapple as well as the best known mild muskmelon. It is an oblong fruit about twelve inches long; the skin is smooth and mottled dark green and yellow.

Pkt. $10 \mathrm{c} ;$ oz. $25 \mathrm{c} ; 1 / 4$ lb. $75 \mathrm{c} ;$ Ib. $\$ 2.50$

We are prepared to fill all orders promptly. Sometimes it is necessary to delay plant and tree orders a few days on account of unfavorable weather, but everything is sent just as promptly as possible. Our methods of packing plants and trees have brought us a great many flattering testimonials. 


\section{Carrots \\ Carotte \\ Mohren \\ Zanahoria \\ Carota}

Good, sandy loam is best adapted for carrots of all varieties. The shorter varieties, however, can be sown on heavier lands, with good results. For garden, sow the early and short varieties at any time after January 1st. For general crop sow in the open field about April 1st, using two or three pounds per acre for rows sixteen to eighteen inches apart. While you get a good uniform root by thinning the young plants, it is not necessary to do so to get a crop of good, average carrots.

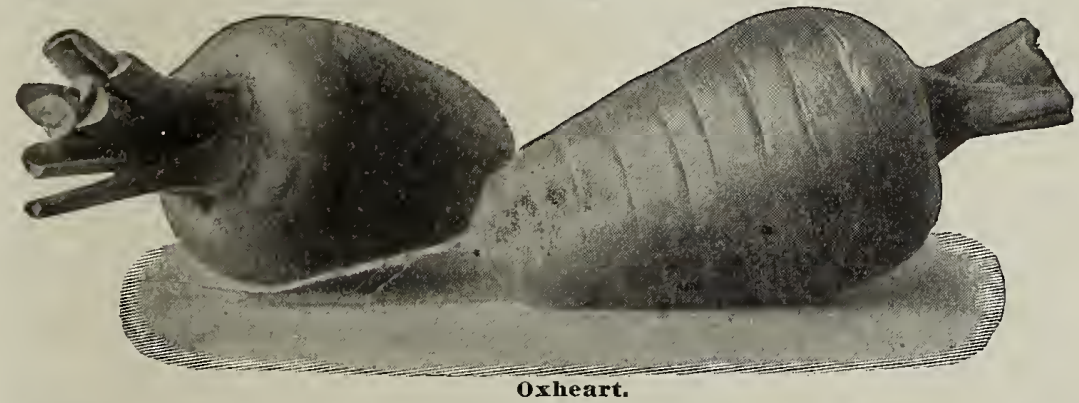

Chantenay or Model. A very popular variety for general purposes; five to six inches long; very stump-rooted; about three inches thick at shoulder; tapering slightly; bright orange-scarlet.

Pkt. 5c; oz. 10c; 1/4 Ib. 25c; Ib. $80 c$

Coreless Long Red. A medium long variety of uniform thickness and very stumprooted, with smooth skin, and bright orange-scarlet color. Core large and not very well defined. A good variety for table use.

Pkt. $5 c$; oz. 10 c; $1 / 4$ Ib. 25 c; Ib. $80 c$

*DANVER'S HALF-LONG. The best variety for general purposes and the most largely used, not only for stock raising, but for table use as well. The perfect type is about eight inches long and about two and a half inches wide at the shoulder, tapering to a sort of half-point at the bottom. Color is a bright orangescarlet. It is a very heavy cropper. Pkt. 5c; oz. $10 \mathrm{c} ; 1 / 4 \mathrm{lb} .25 \mathrm{c} ; \mathrm{Ib} .90 \mathrm{c}$

French Forcing. A very popular variety for forcing. The root is globe-shaped, with distinct tap root. Color bright orange-scarlet.

Pkt. $5 c$; oz. 10 c; $1 / 4$ Ib. 25 c; Ib. 90 c

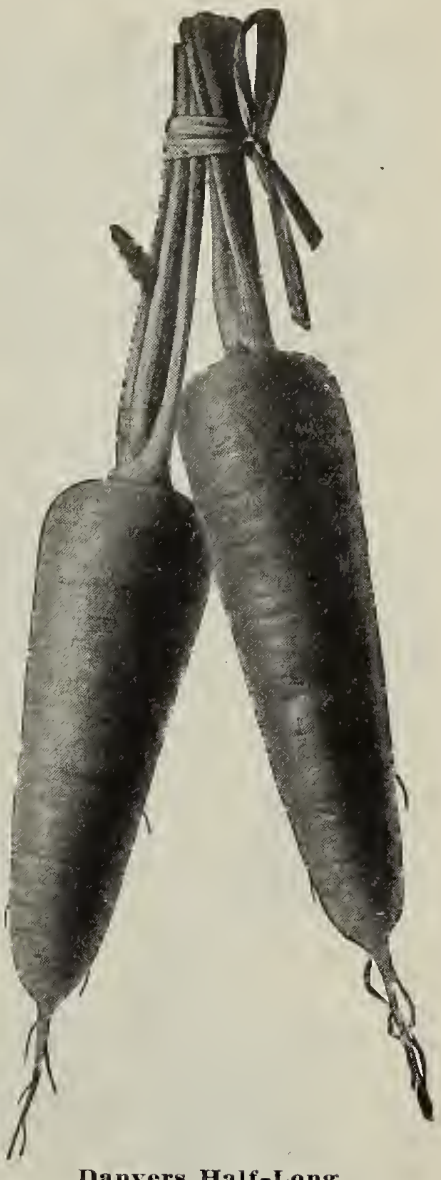

Half-Long Scarlet Stump-Rooted. A variety about as long as Danver's, but not so thick. It is of uniform thickness from shoulder to root and very stumprooted. Pkt. $5 \mathrm{c}$; oz. $10 \mathrm{c} ; \mathrm{l} / 4 \mathrm{lb}$ l 25c; lb. $80 \mathrm{c}$

*IMPROVED SHORT WHITE. The most popular of all white varieties, being a heavy cropper and of a desirable shape to allow easy digging in heavy soils. The true type is very thick in the middle and should not taper abruptly from the shoulder.

Pkt. $5 c$; oz. $10 c ; 1 / 4$ lb. $15 c$; Ib. $50 c$.

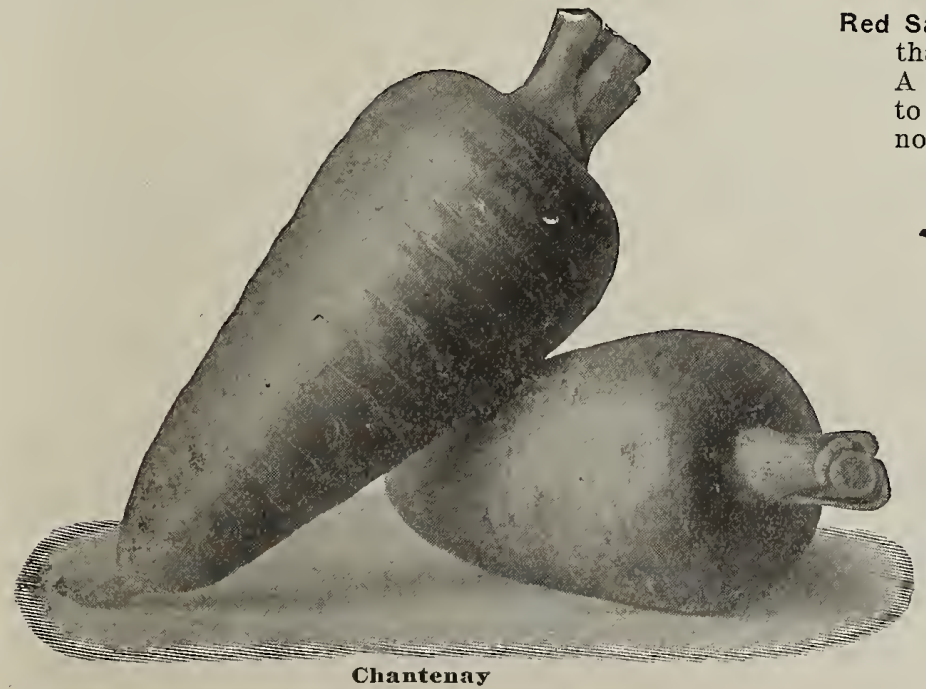

Large White Vosges. A medium-sized variety with tapering and pointed root. A good white variety for heavy soil.

Pkt. $5 c$; oz. $10 c ; 1 / 4$ Ib. $20 c$; Ib. $60 c$

Large White Belgian. The best known and one of the oldest white varieties-is a long-pointed root, and should only be planted on light soils where roots are fairly easy to dig. The variety we offer does not grow above ground with a green shoulder as do some strains.

Pkt. $5 c ; 0 z .10 c ; 1 / 4$ Ib. $20 c ;$ Ib. $50 c$

Red Saint Valery, or New Intermediate. A little longer than Danver's, tapering abruptly, with pointed root. A very desirable, long variety, and rather preferable to Long Orange, being thicker at the shoulder and not so long. Color bright orange-scarlet.

Pkt. $5 c$; oz. $10 c ; 1 / 4$ Ib. 25 c; lb. $80 c$

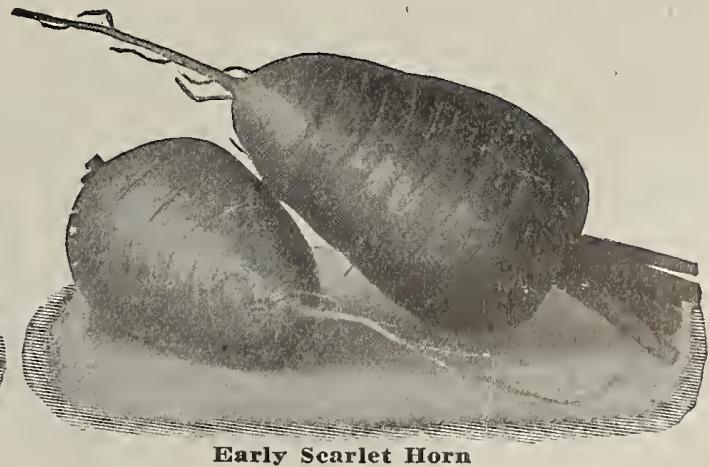




\section{CARROTS-Continued}

* LONG ORANGE. The best long variety, and a good, heavy cropper for light soils where roots can be easily dug. The strain we offer is a bright orangescarlet, and fairly thick, and grows entirely under ground, having no green shoulder. Has the brightest color of all the red carrots.

Pkt. $5 \mathrm{c}$; oz. $10 \mathrm{c} ; 1 / 4$ Ib. $25 \mathrm{c}$; Ib. $75 \mathrm{c}$

*OXHEART, OR GUERANDE. One of the most popular and best croppers among the short carrots. The shape is particularly desirable for heavy soils. The true type is about $4 \frac{1}{2}$ inches long and $3 \frac{1}{2}$ inches thick at the shoulder. It tapers slightly to the bottom, and is very stump-rooted.

Pkt. 5c; oz. 10c; 1/4 lb. 25c; lb. $85 \mathrm{c}$

Scarlet Horn, or Early Short Horn. A good, short variety for table use. The full grown type is about three inches long and $2 \frac{1}{2}$ inches thick at the shoulder; tapers only slightly and is very stump-rooted. It is very early and forms an edible root a short time after planting. Pkt. $5 \mathrm{c}$; oz. $10 \mathrm{c} ; \mathrm{V} / 4 \mathrm{lb} .25 \mathrm{c}$; Ib. $85 \mathrm{c}$

\section{Cauliflower}

\section{Coliflor}

\section{Choufleur}

\section{Cavoloflore}

culture of cauliflower is much the same as that of cabbage. It does not make a good summer crop, however, as it will not head up well in hot weather. It is especially popular as a fall and winter crop, and with market gardeners proves a profitable crop, owing to the scarcity of good market vegetables when caulifiower is at its best. It is easy to grow in the garden, providing the soil is made rich and porous. Plant the seed in beds in June lor fall crop, and transplant to the garden or field in August. For spring crop, plant the seed in protected beds early in January, and the plants will be ready to transplant probably early in March. The young plants should be thinned, since they become very spindly if allowed to grow too thick.

Algiers. One of the best late varieties, forming good, large white heads, late in the fall.

Pkt. 10 c; 1/4 oz. 25c; oz. 75 c; 1/4 Ib. $\$ 2.00$

Burpee's Dry Weather. A strain of the Early Snowball type, which is especially adapted to California. It is a Danish variety (the best Cauliflower comes from Denmark) and is destined to become very popular in our climate.

Pkt. 20 c; $1 / 4$ oz. 75 c; oz. $\$ 2.50 ; 1 / 4$ Ib. $\$ 8.00$

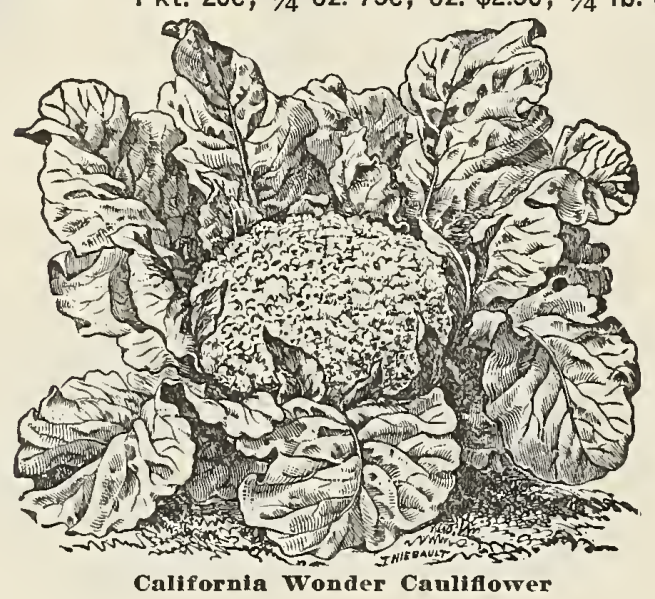

*CALIFORNIA WONDER. A late variety, forming good, large, solid heads during the winter. This variety has given great satisfaction in California wherever tried.

Pkt. 10 c; $1 / 4$ oz. 25 c; oz. 75 c; $1 / 4$ Ib. $\$ 2.25 ;$ Ib. $\$ 6.50$

Early Favorite. An early, hard-heading variety. It is quite hardy and a good market variety.

Pkt. 5c; 1/4 oz. $35 c ;$ oz. $\$ 1.00 ; 1 / 4$ Ib. $\$ 2.50$

*EARLY SNOWBALL. The best and most popular early variety grown. There is a vast difference in the strains of this variety offered, but what we offer is the best imported stock. Those who have had trouble with cauliflower should try this Snowball. It will make uniformly fine heads, even under adverse conditions.

Pkt. $25 c ; 1 / 4$ oz. $75 c ;$ oz. $\$ 2.50 ; 1 / 4$ lb. $\$ 9.00$

Extra Early Dwarf Erfurt. An early variety, forming good, solid white heads. Is very early and almost as good as the best quality of Snowball.

Pkt. 20 c; $1 / 4$ oz. 65 c; oz. $\$ 2.25 ; 1 / 4$ Ib. $\$ 8.00$

Extra Early Paris. A hardy variety quite easy to grow, and forming good heads.

P.kt. $10 c ; 1 / 4$ oz. $25 c ;$ oz. $75 c ; 1 / 4$ lb. $\$ 2.50$

Veitch's Autumn Giant. A large, late variety, very hardy, but especially desirable for the South. The heads are well protected by the foliage, enabling it to resist unfavorable climatic conditions to a greater degree than other varieties.

Pkt. $5 c ; 1 / 4$ oz. $15 c ;$ oz. 50 c; $1 / 4$ Ib. $\$ 1.50$

\section{Celery}

Celeri

Sellerie

Celery is essentially a market crop, and is not usually

thag erated, and the value of having delicious, fresh care required in growing it.

Celery requires water, and lots of it, from the time the seed is sown in boxes in March, until it is pulled in the autumn or winter. The seed is slow to germinate, and the soil where it is planted needs to be kept very wet. As soon as the young plants are about one and one-half inches high they should be transplanted to get good, sturdy plants before they are finally set in the garden or field. When the plants begin to grow vigorously, the soil needs plants before they are finally set in the garden or feld. When the plants begin to grow vigorously, the soll needs earth getting between the stems. As fast as the plants grow above the soil, the earth wants to be hilled around them earth getting between the stems. As fast as the plants grow above the soil, the earth wants to be hilled around them districts. Use one ounce of seed to 15,000 plants, or two ounces per acre.

Boston Market. As the name indicates, this is a popular variety around Boston. A thick, medium-tall variety, which blanches very white and crisp.

Pkt. 5 c; oz. 15 c; $1 / 4$ Ib. $45 c$; Ib. $\$ 1.50$

Crawford's Half-Dwarf. An old favorite for winter use. Medium tall, very hardy, blanches white.

Pkt. $5 c$; oz. $15 c ; 1 / 4$ lb. $45 c$; lb. $\$ 1.50$
Dwarf Golden Heart. The most popular of the old green winter varieties. Rather tall, forming a large bunch, and blanching white and crisp. Is hardy and a good shipper.

Pkt. $5 \mathrm{c}$; oz. $15 \mathrm{c} ; \mathrm{I} / 4$ Ib. $45 \mathrm{c}$; Ib. $\$ 1.50$

Evan's Triumph. A good, green, winter variety, very popular in the North. Forms a large bunch, blanches well, and is very hardy.

Pkt. $5 c ;$ oz. $15 c ; 1 / 4$ lb. $45 c ;$ Ib. $\$ 1.50$ 
Glant Pascal. The most popular of the newer green winter varieties. Rather tall with stems nearly round, and when blanched is white, brittle, and especially good flavor.

Pkt. $5 c$; oz. $15 \mathrm{c} ; 1 / 4$ Ib. $45 c$; lb. $\$ 1.50$

Kalamazoo. A medium short dark-green variety; very hardy; blanches easily, and ships well.

Pkt. $5 \mathrm{c}$; oz. $15 \mathrm{c} ; \mathrm{I} / \mathrm{/}$ Ib. $45 \mathrm{c} ;$ Ib. $\$ 1.50$

*GOLDEN SELF-BLANCHING OR PARIS GOLDEN. The most popular market variety in use, especially for early crop. The plant is naturally golden-yellow (both stem and leaves), but needs to be blanched to make it brittle and fit for table use. Forms a rather small bunch.

Imported-Pkt. $10 \mathrm{c}$; oz. $45 \mathrm{c} ; \mathrm{I} / 4$ Ib. $\$ 1.25$; Ib. $\$ 4.50$

New Rose. The best of the red celeries. The flavor is rather strong in red varieties, but we think is unappreciated by those who like winter varieties. It is tall, forms a large bunch, and blanches to a lightrose pink. Pkt. $5 \mathrm{c}$; oz. $15 \mathrm{c} ; \mathrm{l} / 4 \mathrm{lb} .45 \mathrm{c} ; \mathrm{lb} . \$ 1.50$

Perfection Heartwell. A good, green winter variety, rather tall, forming a large bunch.

Pkt. $5 c$; oz. $15 c ; 1 / 4$ Ib. $45 c ;$ lb. $\$ 1.50$

*WHITE PLUME. One of the most popular of the varieties now in use. Used mostly for a very early crop. A comparatively easy variety to grow, as it is fairly hardy, and being naturally white is easy to blanch. The leaves are also white, tinted with green at tips. forms a medium-sized bunch and is fairly tall. Pkt. 5c; oz. 25c; 1/4 lb. 60c; lb. $\$ 2.00$

*WINTER QUEEN. One of the best winter varieties, and we recommend it especially to market gardeners. It is tall and forms a large bunch. The leaves are light green. Pkt. $5 \mathrm{c}$; oz. $20 \mathrm{c} ; 1 / 4 \mathrm{lb} .60 \mathrm{c} ; \mathrm{Ib} . \$ 2.00$ Celery Seed for Flavoring. (Soup Celery.)

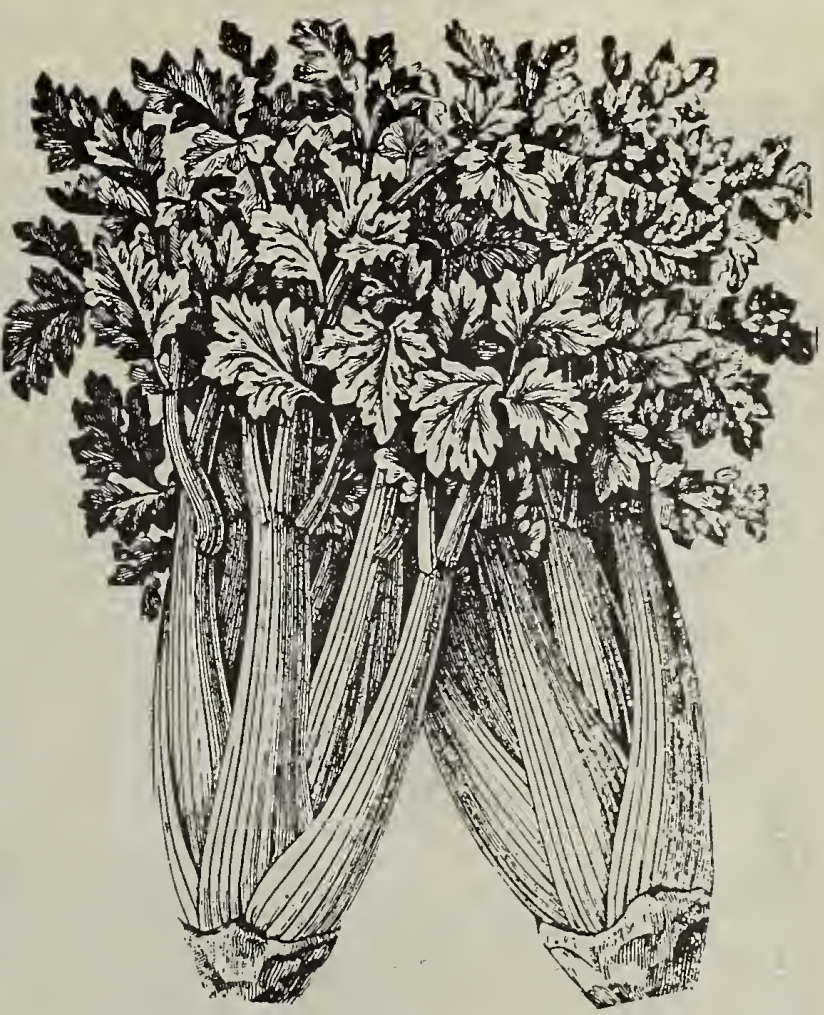

Golden Self-BIanching Celery

\section{Celeriac \\ Knoll-Sellerie}

Celeri-rave Apio-nabo Sedano-rapa

This plant resembles celery in flavor, but the stems are very strong, and only the root is palatable. It should be treated much as celery, so far as planting the seed is concerned. The plant requires only a little hilling, however, root.

Giant Smooth Prague. The best variety. Forms a good, thick root as much as four inches in diameter and nearly globular. Pkt. 5 c; oz. 20c; 1/4 lb. 50c; Ib. $\$ 1.75$

\section{Chervil \\ Cerfeuil \\ Bensenlauch \\ Perifollo \\ Cerfoglio}

Can be planted any time in the early spring. The leaves should be kept cut, and if not allowed to run to seed, will keep green for a long time. Is more finely curled and handsome than parsley, and makes an excellent plant
for garnishing.

Curled. Very finely curled, somewhat resembling parsley and used in same manner.

Pkt. $5 c$; oz. $10 c ; 1 / 4$ lb. $30 c ;$ lb. $\$ 1.00$

\section{Chicory}

\section{Chicoree sauvage \\ Cichorienwurzel \\ Achicoria \\ Cicoria selvatica}

Used as a substitute for coffee when the roots are dried and ground. The roots are also used for cooking and are very palatable. Sow early in the spring, thin the young plants to six inches, and keep well hoed. The plant spreads from the root and is perennial

Large Rooted, or Coffee. The largest rooted and best variety.

Pkt. $5 \mathrm{c} ;$ oz. $10 \mathrm{c} ; \mathrm{I} / 4$ lb. $25 \mathrm{c} ;$ lb. $75 \mathrm{c}$

\section{Corn-Sweet or Table Varieties}

Mais

Welshkorn
Maiz
Mais

As corn is very sensitive to frost, it cannot be planted with any degree of safety until about the middle of April, except in sections that are notably free from late frost. Moist, rich soil is best for corn, and frequent hoeing or cultivating improves it. The small but rich mountain valleys seem especially favorable for good table corn.

In cutting corn for the table it is important that it be picked at just the right time, especially when not too old. Frequent small plantings of the several varieties in succession will keep a good supply available for the table all summer.

Express or freight charges are not prepaid. If large quantities are wanted, write us for special quotations.

Black Mexican. One of the best medium early varieties. Although when ripe the seed is dark bluish or black, when ready for table use it is white. It is of especially fine, sweet flavor and very tender.
It seems to do well in most parts of California Pkt. 10c; lb. 20c, postpaid; by express or freight, Ib. $10 \mathrm{c} ; 10$ lbs. $80 \mathrm{c}$; 100 lbs. $\$ 7.00$. 


\section{CorN-Continued}

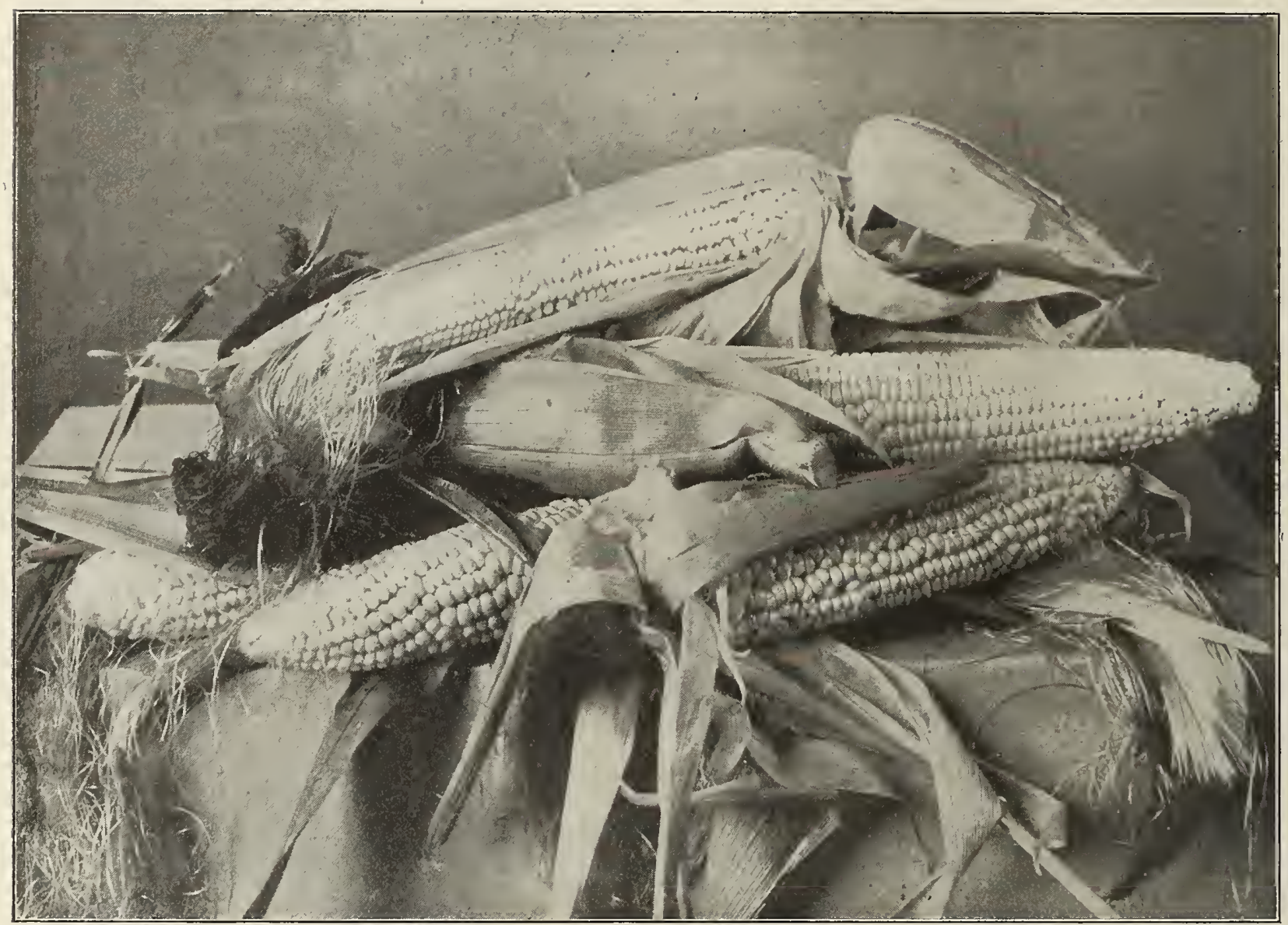

Stowell's Evergreen Sweet Corn.

A main crop standard variety-one of the very best.

Burpee's Golden Bantam. A very early variety. The ears are but medium size, but are thickly set with delicious yellow kernels. The quality of this variety is superb, and it has become a general favorite early sweet corn with all who have tried it. Pkt. $10 \mathrm{c}$; Ib. $25 \mathrm{c}$, postpaid; by express or freight, Ib. 10c; 10 lbs. $80 \mathrm{c} ; 100$ lbs. $\$ 7.00$.

Crosby's Early. A fine, early variety, growing about 4 feet in height. Is twelve-rowed, and very popular. Pkt. $10 \mathrm{c}$; Ib. $20 \mathrm{c}$, postpaid; by express or freight, lb. $10 \mathrm{c} ; 10 \mathrm{lbs} .80 \mathrm{c} ; 100 \mathrm{lbs} . \$ 7.00$.

Country Gentleman. One of the best of the late varieties. Has a long, white cob, closely filled with long "shoe peg" kernels. Is remarkably fine flavored and sweet, and is frequently used by canners. Pkt. 10c; lb. 25c, postpaid; by express or freight, lb. $15 \mathrm{c} ; 10$ lbs. $\$ 1.25 ; 100$ lbs. $\$ 9.00$.

Early Red Cob Cory. One of the best extra early varieties. Ears are about six inches long, and eightrowed. Pkt. 10c; Ib. 20c, postpaid; by express or freight, Ib. 10c; 10 lbs. $80 \mathrm{c} ; 100$ lbs. $\$ 7.00$.

Early Minnesota. The best early variety for marliet and private gardens. Between Crosby's and Cory's in earliness. Stalks about five feet high; ears long, and eight-rowed. Pkt. 10c; lb. 20c, postpaid; by express or freight, Ib. 10c; 10 lbs. $80 \mathrm{c} ; 100 \mathrm{lbs}$. $\$ 7.00$.
Early White Cob Cory. An extra early variety with remarkably white grains, especially when cooked. Ears are six to seven inches long. Of good quality. Pkt. 10c; lb. 20c, postpaid; by express or freight, lb. $10 \mathrm{c} ; 10$ lbs. $80 \mathrm{c} ; 100$ lbs. $\$ 7.00$.

*EARLY MAMMOTH, OR ALAMEDA. The best variety for California and the one most generally used here. Forms very large ears, which are quite sweet and of fair quality. It withstands our dry summers well, and is usually quite free from worms, and the ears fill well. Pkt. 10c; Ib. 20c, postpaid; by express or freight, Ib. $10 \mathrm{c} ; .10$ lbs. $80 \mathrm{c} ; 100$ Ibs. $\$ 7.00$.

Late Mammoth. A mammoth variety, with very long, thick ears, which are covered with very wide, thick kernels. Has the largest ears of any variety. Is very late. Pkt. 10c; Ib. 20c, postpaid; by express or freight, Ib. $10 \mathrm{c} ; 10$ lbs. $80 \mathrm{c} ; 100$ lbs. $\$ 7.00$.

Moore's Early Concord. A medium early variety. Ears are rather short and well filled with 14 to 16 rows of kernels. A good variety for private garden or for canning. Pkt, 10c; lb. 20, postpaid; by express or freight, Ib. $10 \mathrm{c} ; 10$ lbs. $80 \mathrm{c} ; 100$ lbs. $\$ 7.00$.

Old Colony. A good late variety of rich, sweet flavor. Ears bear 16 to 20 rows of liernels, and are very heavy and solid. Pkt. 10c; Ib. 20c, postpaid; by express or freight, Ib. 10c; 10 lbs. $80 \mathrm{c} ; 100$ lbs. $\$ 7.00$. 
Perry's Hybrid. A good second early variety. Usually produces two good-sized ears, set low on the stalk. Of fine quality, sweet, and tender. Pkt. 10c; Ib. 20c, postpaid; by express or freight, lb. $10 \mathrm{c}$; 10 Ibs. $80 \mathrm{c}$; 100 ibs. $\$ 7.00$.

*STOWELL'S EVERGREEN. The most popular and best main crop variety. Of good, strong growth, about 6 feet high. Ears keep in condition for boiling for a remarkably long time. The quality is excellent. Pkt. 10c; lb. 20c, postpaid; by express or freight, Ib. 10c; 10 ibs. $80 \mathrm{c} ; 100$ Ibs. $\$ 7.00$.

White Evergreen. Like Stowell's Evergreen, it is a good main crop variety, but has the remarkable quality

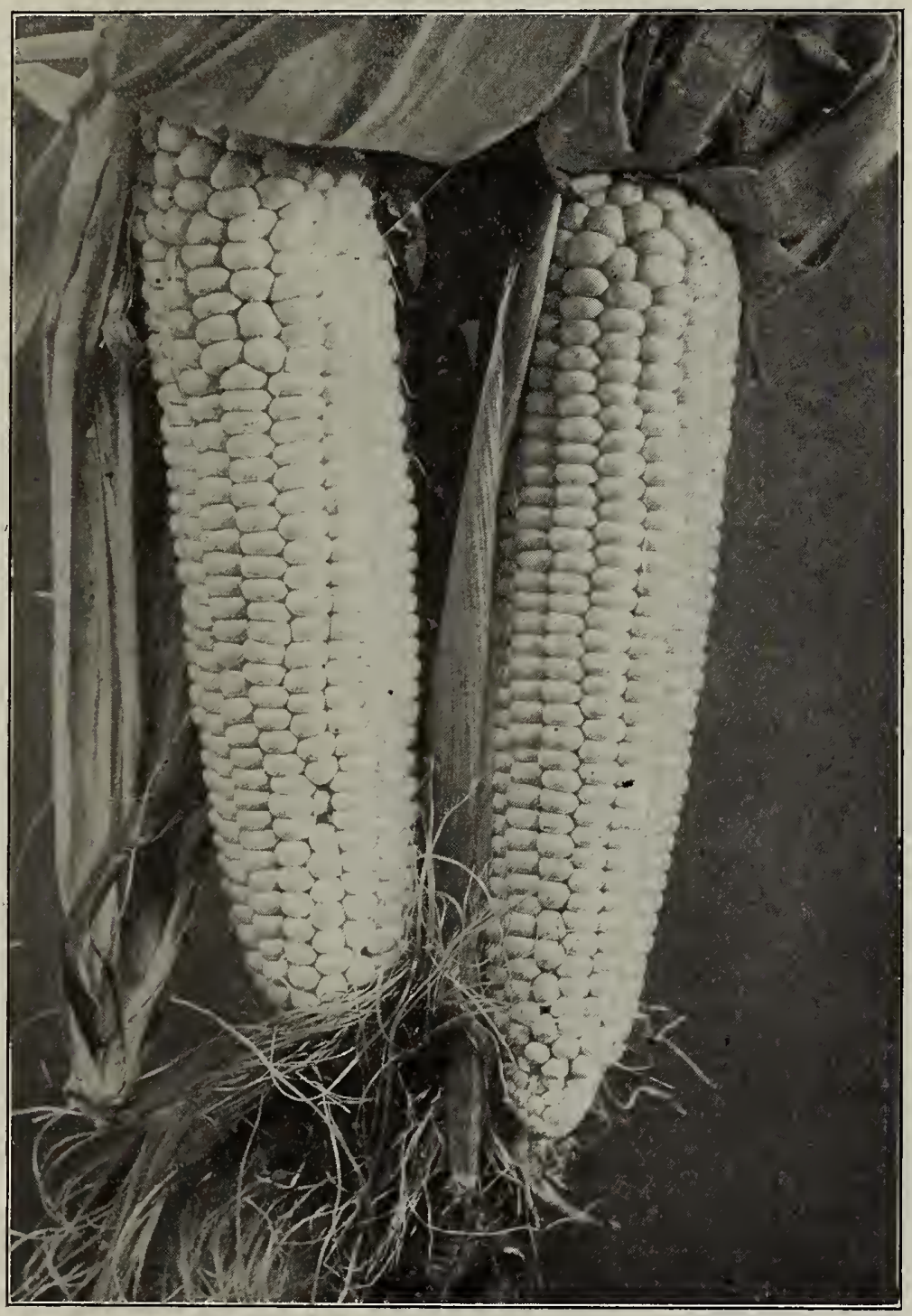

Early Mammoth, or Alameda Sweet

The best adapted to our California Climate.

of being snow-white. It is invaluable for canners,' market gardeners, and all whó desire a good evergreen corn. Pkt. 10c; lb. 25c, postpaid; by express or freight, Ib. $15 \mathrm{c} ; 10$ lbs. $\$ 1.25 ; 100$ lbs. $\$ 10.00$.

Extra Early Adams. The earliest of all corn and the first to make ears. Plant dwarf and stocky and grains of fair quality. Pkt. 10c; lb. 20c, postpaid; by express or freight, Ib. 10c; 10 lbs. $80 c$; 100 Ibs. $\$ 7.00$.
Early Eight-Rowed Canada, also known as the Yellow Flint. A rapid growing, early variety, and for this reason largely used for replanting. Very valuable where the seasons are short. Per Ib. 20c, postpaid; by express or freight, lb. $10 \mathrm{c}$; 10 lbs. $60 \mathrm{c}$; $100 \mathrm{lbs}$. $\$ 5.00$.

Early Adams. Although not a sweet corn, can often be used as such on account of its fine, white kernels, which are quite sweet and tender. Is very hardy and can be planted earlier than the early varieties of sweet corn. Pkt. $10 \mathrm{c}$; Ib. 20c, postpaid; by express or freight, Ib. 10c; 10 lbs. 65 c; 100 lbs. 6.00 .

King Phillip. An old New England favorite. The ears are long, and the variety is very early. Grains, coppery red. Per Ib. 20c, postpaid; by express or freight, lb. $10 c ; 10$ lbs. $60 c$; 100 Ibs. $\$ 5.00$.

Early Golden Dent, or Pride of the North. A very early dent variety, and especially valuable on account of its extreme earliness. Ears 8 to 10 inches long, with 10 to 16 rows of slender, deep yellow grains. Per lb. 20c, postpaid; by express or freight, Ib. 10c; 10 lbs. $60 \mathrm{c} ; 100$ lbs. $\$ 5.00$.

*LEAMING. A very popular, tallgrowing variety. Is early; stalks are leafy, making excellent fodder. Kernels are long and deep golden yellow. It is the very best yellow corn on the market. Per Ib. 20c, postpaid; by express or freight, lb. $10 \mathrm{c} ; 10$ Ibs. $60 \mathrm{c} ; 100$ lbs. $\$ 5.00$.

White Cap Yellow Dent. An early and hardy variety, growing 6 to 7 feet in height. Ears are 8 to 10 inches in length. Cob small and 16 to 18 rowed. The outer end of the grain is white, while the inner portion is clear yellow. Per Ib. 20c, postpaid; by express or freight, Ib. $10 \mathrm{c} ; 10$ Ibs. 60c; 100 Ibs. $\$ 5.00$.

*SANFORD WHITE FLINT. An early, tall variety, bearing large ears which are well filled with long, pure white kernels. The very best white corn on the market. Per lb. 20c, postpaid; by express or freight, lb. $10 \mathrm{c} ; 10$ lbs. $60 \mathrm{c} ; 100$ Ibs. $\$ 5.00$.

Wisconsin White Dent. A tall-growing variety; large eared; 16 to 18 rowed; grains large and white. Per Ib. $20 \mathrm{c}$, postpaid; by express or freight, lb. $10 \mathrm{c} ; 10$ Ibs. 60 c; 100 lbs. $\$ 5.00$.

sweet Corn for Fodder. As this corn is always wanted in large quantities, write us for special quotations.

Pop Corn, White Rice. The most popular variety; very prolific; ears short; kernels long, resembling rice in shape; color white. Per lb. 20c, postpaid; by express or freight, Ib. $10 \mathrm{c} ; 10$ lbs. $75 \mathrm{c} ; 100$ lbs. $\$ 6.00$.

Kaffir Corn
Egyptian Corn. See Field Seeds. 


\section{Collards}

Chou Cabu

Blatter-Kohl

Cabu

A plant bearing a large mass of leaves on the top of a stout stalk. It is a species of cabbage, and the flavor is the same. It bears leaves all through the winter, and is used especially in the South for cabbage greens. Young plants may be started in boxes in early spring, and the young plants transplanted, allowing plenty of room for each plant.

North Carolina Short Stem. A dwarf or short-stemmed variety. Forms medium large, loose heads of lightgreen leaves.

*TRUE GEORGIA. The well-known very large variety. Grows from four to five fot high, large, loose head. Leaves are tinged with purple.

Pkt. $5 c$; oz. $10 c ; 1 / 4$ Ib. $30 c ;$ lb. $\$ 1.00$

\section{Corn Salad or Fetticus}

Mache

Stecksalat

Macha Valerianilla

Valeriana

A salad plant used as a substitute for lettuce-1n salads, or may be cooked like spinach for greens. It does well in winter and spring. On rich soil the leaves grow quickly and are exceedingly tender.

Large Leaved. Very tender leaves, which grow out rapidly after being cut. Pkt. $5 \mathrm{c} ; \mathrm{oz} .10 \mathrm{c} ; \mathrm{l} / 4 \mathrm{lb} .20 \mathrm{c} ; \mathrm{lb} .60 \mathrm{c}$

\section{Cucumbers}

Concombre

Gurke

Pepino

Cetriolo

Are sensitive to frost, and cannot be planted until the last of April. They require a great deal of water, and unless planted on very wet soll, will require frequent irrigation throughout the summer. Plant in hills four feet each way, and leave two or three plants to each hill. The soil should be made very rich with well-rotted stable manure, well spaded in.

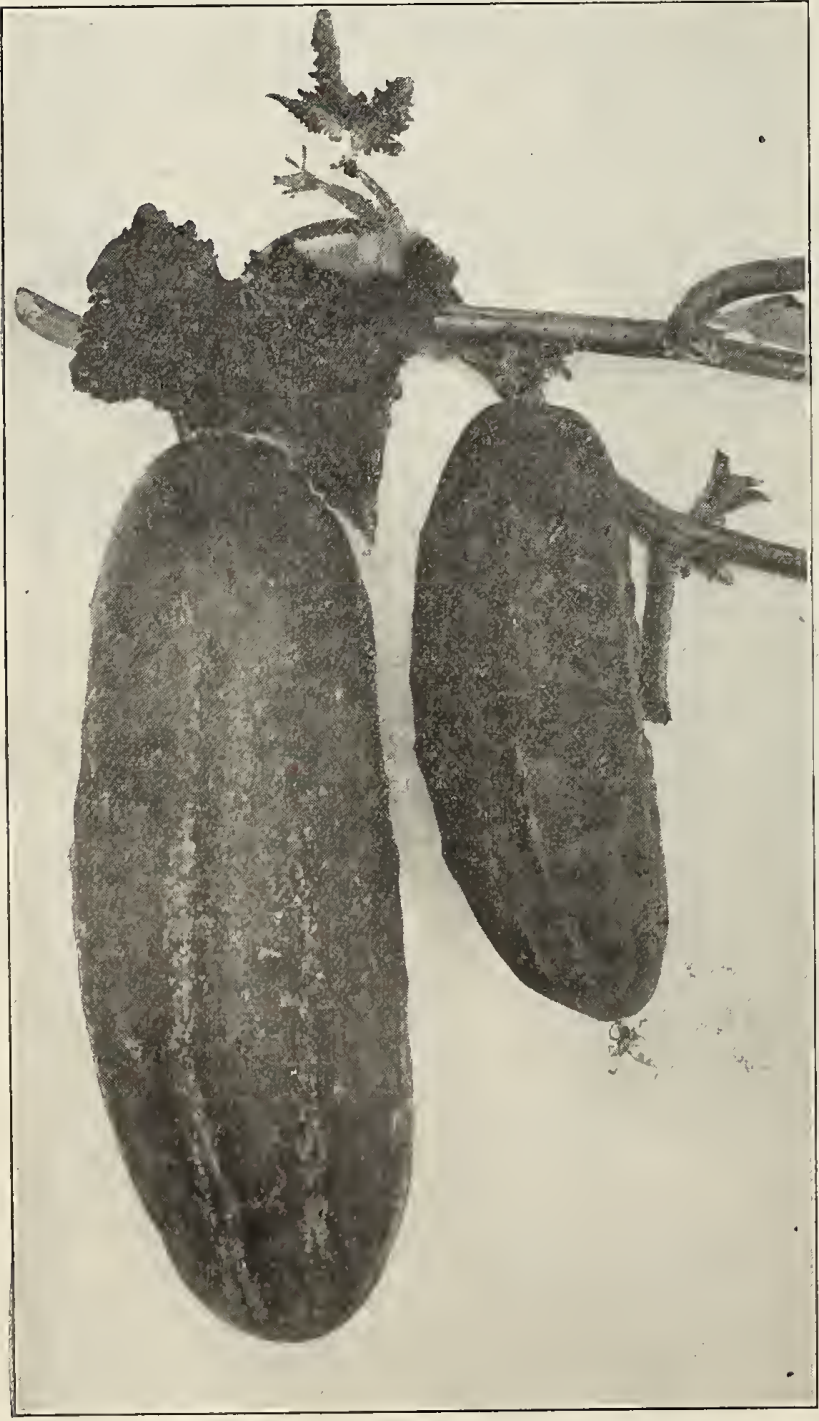

Cueumber- "Arlington White Spine"

The best variety for our California soll and climate.
Cucumbers are very easy to grow, and. a few hills will produce an abundance for an average family.

*ARLINGTON WHITE SPINE. A rich, dark-green variety, turning white when ripened. The fruit is about 7 inches long when in marketable condition and very straight and even in shape. Is early, and good for forcing and out-of-door culture.

Pkt. $5 \mathrm{c}$; oz. $10 \mathrm{c} ; 1 / 4$ Ib. $25 \mathrm{c}$; Ib. $80 \mathrm{c}$

Chicago Pickling. A medium long deep-green variety, turning yellow at maturity. The fruit is finely shaped, being slightly blunt at both ends. It is the popular pickle variety in use about Chicago.

Pkt. $5 c$; oz. 10 c; 1/4 Ib. 25c; lb. 80 c

Cool and Crisp. A fine garden variety, deep green and crisp, and is of the White Spine type, and pure white when ripe.

Pkt. 5c; oz. $10 \mathrm{c} ; 1 / 4$ Ib. $25 \mathrm{c}$; Ib. $80 \mathrm{c}$

Cumberland Pickling. This variety is the result of a cross between Paris Pickling and White Spine, and retains the characteristics of the former in being thickly covered with small white spines. The vine is sturdy and very prolific. The mature fruits are from 9 to 10 inches in length.

Pkt. $5 c ;$ oz. $10 c ; 1 / 4$ lb. $30 c ;$ lb. $\$ 1.00$

Early Cluster. A very productive variety, bearing its fruit in clusters of two or three. The fruit is short asd very dark green; a trifle paler at the blossom end.

Pkt. $5 \mathrm{c} ;$ oz. $10 \mathrm{c} ; 1 / 4$ lb. $25 \mathrm{c} ;$ lb. $80 \mathrm{c}$

Early Short Green, or Early Frame. A very desirable variety for either pickling or table use. Fruit straight; small at each end; bright green.

Pkt. $5 c$; oz. $10 \mathrm{c} ; 1 / 4$ lb. $30 \mathrm{c} ; \mathrm{Ib} . \$ 1.00$

Everbearing. Very early and very prolific. Fruits 4 to 6 inches long; quite thick and blunt at the end and of a rich, dark-green color.

Pkt. 5c; oz. $10 c ; 1 / 4$ lb. $30 c$; Ib. $\$ 1.00$

Extra Early Green Prolific, or Boston Pickling. A very prolific variety, used principally for pickles. Fruit medium sized, bright green, very even and symmetrical. Pkt. 5c; oz. 10c; $1 / 4$ lb. $30 \mathrm{c} ; \mathrm{lb} . \$ 1.00$

Extra Long White Spine, or Evergreen White Spine. A popular variety having long, rich dark-green fruits with very tender, white, and crisp flesh.

Pkt. $5 c$; oz. 10c; 1/4 Ib. $30 c$; lb. $\$ 1.00$

Fordhook Famous. A long White Spine variety, growing from 10 to 12 inches. Fully as long as Long Green and of equally good quality.

Pkt. $5 \mathrm{c}$; oz. $10 \mathrm{c} ; \mathrm{I} / 4$ Ib. $40 \mathrm{c}$; Ib. $\$ 1.25$ 
Gherkin, or West India Gherkin. An extremely small fruited variety, grown exclusively for pickles. It has no value for slicing; is very prickly, but tender and crisp if picked when young. Seed germinates slowly. $\quad$ Pkt. 5c; 0z. 10c; 1/4 lb. 30c; Ib. 1.00

Japanese Climbing. A good variety for training to a trellis. Forms long fruit of rich, dark-green color. The flesh is white, crisp, and of good flavor.

Pkt. $5 c ; 0 z, 10 c ; 1 / 4$ Ib. $30 c ;$ ib. $\$ 1.00$
*LONG GREEN. The best known and the most popular variety for general use. Is vigorous and productive, and forms fruit fit for use almost as early as the shorter varieties. The mature fruit is almost 12 inches long. The skin is of a deep green, and the flesh is solid, crisp, and of fine quality. We have the very best strains of this variety, and recommend it as much the best cucumber of all, and the variety every one should plant.

Pkt. $5 c$; oz. $10 \mathrm{c} ; 1 / 4$ Ib. $30 \mathrm{c} ; \mathrm{Ib} .90 \mathrm{c}$

\section{Cress}

There are two species of cress, as noted below. The first named should be sown in drills about sixteen inches apart in rich ground, early in the spring. Several sowings should be made at intervals to secure a succession. Watereress should be sowed along the banks of running water where there is good soil, and after the seed is up it needs no further cultivation, since the plants spread over the water and make a mass of fine, edible leaves.

Fine Curled (Pepper Grass.) Leaves finely cut or curled like parsley. The leaves are pungent, and are used to mix with lettuce.

Pkt. $5 c$; oz. $10 c ; 1 / 4$ Ib. 20c; lb. $50 c$
True Water. Forms a plant, the leaves of which are used for salad or for garnishing. Thrives only when the roots and stems are submerged in water. Pkt. $10 \mathrm{c} ;$ oz. $35 \mathrm{c} ; 1 / 4$ lb. $\$ 1.00 ;$ Ib. $\$ 3.50$

\section{Dandelion}

\section{Pissenlit}

Barbeblum

Amargon

Dente di leone

An easily grown plant, now much esteemed for greens, which are cooked like mustard and spinach. Sow the seed in May or June on good, rich soil, and thoroughly cultivate, when the leaves will be ready to cut the following spring. An ounce will sow 200 feet of row.

Improved Large Leaved. The largest leaved and best cutting variety.

Pkt. $10 \mathrm{c} ;$ oz. $50 \mathrm{c} ; \mathrm{1} / 4$ lb. $\$ 1.50 ;$ lb. $\$ 5.00$

\section{$\mathrm{Eg} g=$ Plant}

Aubergine

Le:engena

Eierpflanze

The seed germinates slowly, and should be started under glass, with moderately high temperature, about March 1st. When about an inch high transplant carefully to the garden or field, but not until all danger of frost is over. Egg-plant does not do so well where cool nights prevail, as in places where the nights are warm. It needs a warm climate to insure quick and uninterrupted growth.

Black Beauty. A very early variety; rich púrple black in color and a remarkable market variety. Pkt. $10 \mathrm{c} ;$ oz. $45 \mathrm{c} ; 1 / 4$ lb. $\$ 1.25$; l. $\$ 4.50$

Early Long Purple. An early variety and also a very profitable one. The fruit is long and of a rich dark purple.

Pkt. $5 c$; oz. $15 c ; 1 / 4$ lb. $50 c ;$ lb. $\$ 1.75$

*NEW YORK IMPROVED LARGE PURPLE. The principal market variety; plants are large and spreading; fruit large and of deep rich purple.

Pkt. $10 \mathrm{c} ;$ oz. $30 \mathrm{c} ; \mathrm{l} / 4$ lb. $\$ 1.00 ;$ Ib. $\$ 3.00$

Black Pekin. An early, prolífic variety, and valuable for market gardener's' use. Fruit is nearly round; skin smooth and black.

Pkt. $10 \mathrm{c} ;$ oz. $30 \mathrm{c} ; \mathrm{l} / 4$ lb. $\$ 1.00 ; \mathrm{lb} . \$ 3.50$ (t)

White Pearl. A smooth-leaved variety with large, egg-shaped, pure white fruit.

Pkt. $10 \mathrm{c} ;$ oz. $30 \mathrm{c} ; 1 / 4$ Ib. $\$ 1.00 ;$ Ib. $\$ 3.50$

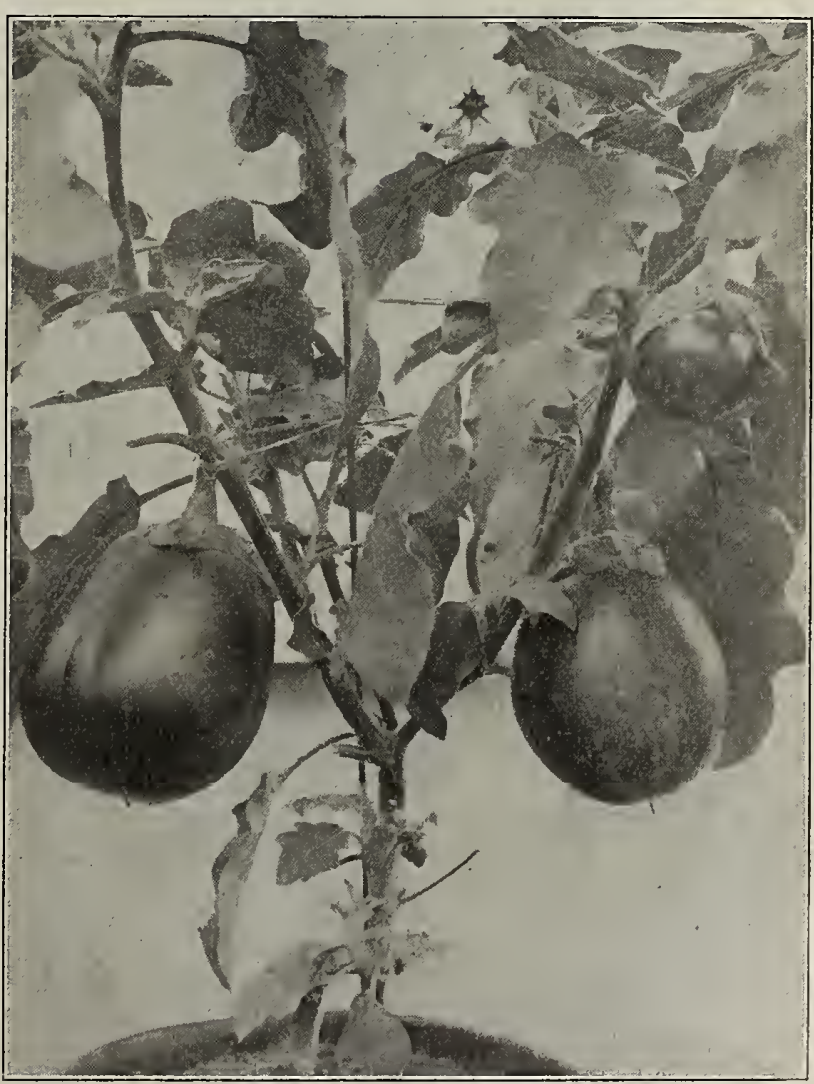

New York Improved Large Purple Egg Plant The best variety for all purposes. 


\section{Endive}

Endive

Endivie

Endivia

Indivia

A salad vegetable which is becoming very valuable for winter use. The seed should be sown in June or July in rows, and thinned to about six inches apart. When quite well grown, the outer leaves should be tied, thus blanching the inner leaves and the heart. It is hardly palatable until after frost, being rather bitter if used in summer.

*BROAD-LEAVED BATAVIAN, or ESCAROLLE. A variety having wide, thick leaves, straight at the edges and curved toward the center. Color, dull green. Pkt. 5c; oz. 10c; 1/4 Ib. 30c; Ib. $\$ 1.00$

*GREEN CURLED. A very curly variety, the mid rib being wide and whitish and the outer edges very much indented and curled. A very attractive plant,

and one of the very best varieties.

Pkt. $5 c$; 0z. $10 c ; 1 / 4$ lb. 30 c; lb. $\$ 1.00$

Staghorn. A curly type, the lobes and divisions of the leaves being wider than in the curled varieties. Is a popular garden sort in San Francisco.

Pkt. 5c; 0z. 15c; 1/4 Ib. 30c; Ib. $\$ 1.00$

White Curled. A light yellowish-green variety; very curly and quite ornamental. A good variety for general use. Pkt. 5c; oz. 15c; 1/4 Ib. 50c; Ib. $\$ 1.50$

\section{Kale or Borecole}

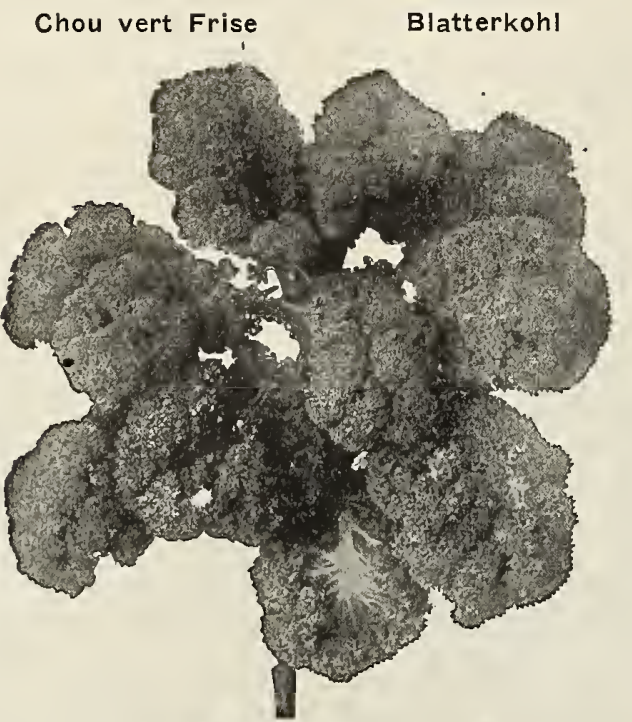

Col

Cavola Verde

A species of cabbage, forming a mass of leaves, some varieties being very beautiful and curly. The leaves are cooked as greens. The seed should be planted in September, and the plants will be ready to use in the winter. It is hardy and will withstand frost and snow.

*DWARF CURLED SCOTCH. The most popular sort for general use. The leaves are very curly and very tender. Color bright green.

Pkt. $5 c$; oz. $10 c$; 1/4 Ib. 25c; Ib. $75 c$

Green Curled Scotch, Tall. A very hardy variety, growing about $2 \frac{1 / 4}{4}$ feet high. Is very curly and makes a beautiful plant. Stands the winter well.

Pkt. 5c; oz. 10c; I/4 Ib. 25c; Ib. $75 \mathrm{c}$

Dwarf Purple German. Similar to Dwarf Curled Scotch, excepting the leaves are purple.

Pkt. $5 c$; oz. $10 c ; 1 / 4$ Ib. $30 c$; Ib. $\$ 1.00$

Jersey Kale. See Farm Seeds.

Siberian. A plain-leaved variety, having very little curl to the large, green leaves, although the edges are cut and curled slightly.

Pkt. $5 c ;$ oz. $10 c ; 1 / 4$ Ib. $25 c ;$ Ib. $75 c$

\section{Kohl Rabi}

\section{Chou Rave}

Kohlrabi

A plant forming a firm bulb above the ground and bearing short leaves. The bulb is the edible part, and when cooked tastes very much like turnip. If the seed is sown early, the young bulbs will be ready to use in spring, and a planting in July will secure good vegetables for fall use. The seed should be planted in the open garden, and the young plants thinned to four or six inches. It does not transplant well, unless when very small.

*EARLY WHITE VIENNA. The most desirable variety for general use. Is very early and has small tops. Color, light silvery green.

Pkt. 5c; oz. 20 c; $1 / 4$ lb. 60 c; Ib. $\$ 2.00$

Early Purple Vienna. An early variety with a ibright purple bulb. The leaf and stems being green and tinged with purple.

Pkt. $5 c$; oz. 20 c; $1 / 4$ Ib. 60 c; lb. $\$ 2.00$

Large Green. A popular table variety, having light green bulb. Pkt. $5 c$; oz. $15 \mathrm{c} ; \mathrm{V} / 4 \mathrm{Ib} .45 \mathrm{c} ; \mathrm{Ib} . \$ 1.50$

\section{Colinabo}

Cavolo rapa

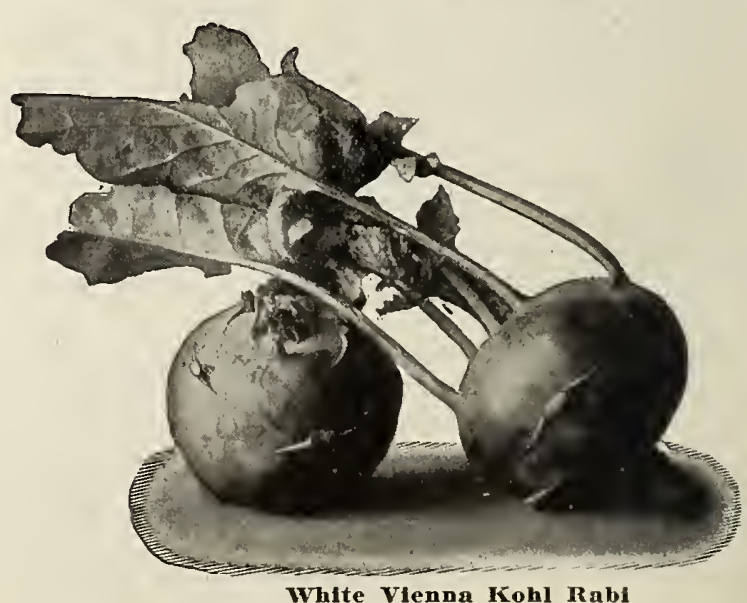




\section{Leek}

Poireau

Poireau Lauch

\section{Porro}

A species of onion which does not form a bulb, but is used for its mild and delicious root, stem, or neck. It can a planted in rows, and the young plants thinned to about four inches. When well grown, hill up with earth to get unusual merit, and is not half appreciated by the American people, while it is regarded as a great favorite by many of our foreign residents.

American Flag. A very goód, strong-growing variety, forming large stems of good flavor.

Pkt. $5 \mathrm{c} ;$ oz. 10c; 1/4 Ib. 30c; Ib. $\$ 1.00$

Carentan. The largest variety, though the stems are not so long as some other varieties. Leaves are very broad. Pkt. 5c; oz. $15 \mathrm{c} ; 1 / 4$ lb. 40 c; lb. $\$ 1.50$ *GIANT MUSSELBURGH. The best variety, having good, thick stems, which are also long. Very vigorous and of sweet, mild flavor.

Pkt. $5 c$; oz. 15 c; 1/4 Ib. 40 c; lb. $\$ 1.25$

\section{Lettuce}

\section{Laitue}

Laitue Lattich, Kopsalat

\section{Lattich, Kopsalat}

type; the curly and thin-leaved tiont-head classes or types-by the thick-leaved, smooth-edged eabbage-heading and the Cos or celery type. There are early, medium early, and late varieties of bunehing or non-heading type, especially adapted for greenhouse, hotbed, winter, spring, summer, and autumn uses. There is so great a difference in localities in regard to the value of lettuce, that a uniform rule for culture cannot be adopted. For the ordinary house garden it is desirable to use one variety of each type, and several plantings should be made to secure a succession. The seed should be planted in rows eighteen inches apart, as early as possible, and the young plants of cabbage varieties should be thinned to four inches apart. Varieties that do not head may be left quite thick, and when fairly well grown, those thinned out may be used.

Big Boston. A popular market variety, used largely in the South to grow winter lettuce for Northern markets. A light-green cabbage variety, slightly tinged with brown in the head. Has a particularly fine golden buttery head.

Pkt. 5 c; oz. $15 c$; 1/4 lb. 40 c; lb. $\$ 1.25$

Black Seeded Simpson. A bunching variety, forming no definite head. It has a large mass of fine, brittle leaves of a lightgreen attractive color. $\quad$ Pkt. $5 \mathrm{c} ;$ oz. $15 \mathrm{c} ; \mathrm{I} / 4 \mathrm{Ib}$. $40 \mathrm{c}$; Ib. $\$ 1.25$

Black Seeded Tennisball. An old, well-known variety. Very desirable for hotbed culture in winter and for withstanding heat in summer. A light-green cabbage sort, forming hard heads.

Pkt. $5 c$; oz. $15 c ; 1 / 4$ lb. $40 c$; lb. $\$ 1.25$

Boston Market. The well-known and popular hothouse variety of New England. Needs to be quickly grown to be of good flavor. Light-green cabbage variety, slightly tinged with brown on the head. Forms a compact, buttery head.

Pkt. 5 c; oz. 15 c; $1 / 4$ Ib. 40 c; Ib. $\$ 1.25$

* CALIFORNIA CREAM BUTTER. A very popular variety for autumn and winter use. Forms a very large head, which is very buttery, and of a rich golden-yellow inside. The leaves are thick and of bright green, slightly tinged with brown on top of head, and the outer leaves are slightly spotted with inconspicuous brown spots. Easy to grow and a good shipping variety.

Pkt. $5 \mathrm{c} ;$ oz. $15 \mathrm{c} ; \mathrm{I} / 4$ Ib. $40 \mathrm{c}$; Ib. $\$ 1.25$

Deacon. A large cabbage variety having thick, bright green leaves; forms a large, buttery head; very bright golden-yellow inside.

Pkt. $5 c ;$ oz. $15 c ; 1 / 4$ Ib. $40 c ;$ lb. $\$ 1.25$

Denver Market. A handsome variety, forming tight, conical heads. The leaves are very deeply savoyed, and even the outside leaves are tender and clisp. Color is light green.

Pkt. $5 c$; oz. $15 \mathrm{c} ; 1 / 4$ lb. $45 \mathrm{c} ; \mathrm{lb} . \$ 1.50$

Drumhead or Malta. Sometimes called "Chinese" lettuce. A very large, tight-heading variety. Leaves are rather coarse, but very brittle and tender. Is dark green and slightly curled.

Pkt. $5 \mathrm{c} ;$ oz, $15 \mathrm{c} ; \mathrm{1} / 4 \mathrm{lb} .40 \mathrm{c} ; \mathrm{lb} . \$ 1.25$

Early Curled Simpson. A loose-bunching sort, forming no definite head. Is crisp and tender; light green in color. Is very hardy and easy to grow.

Pkt. $5 c ;$ oz, $15 \mathrm{c} ; 1 / 4$ lb. $40 \mathrm{c}$; lb. $\$ 1.25$

Grand Rapids. The well-known forcing variety for the middle West, where butter-headed or cabbage varieties do not grow well under glass. Is a loose-bunching variety, forming no definite head. Is extremely curly, and its light yellowish-green color makes it very attractive.

Pkt. 5 c; oz. 15 c; 1/4 Ib. 40 c; lb. $\$ 1.25$
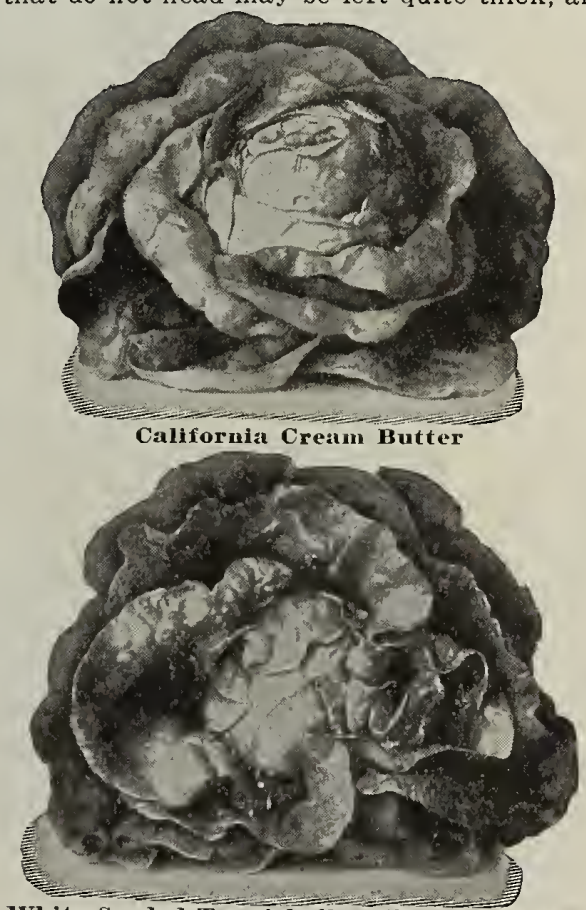

White Sceded Tenuísball or Boston Market

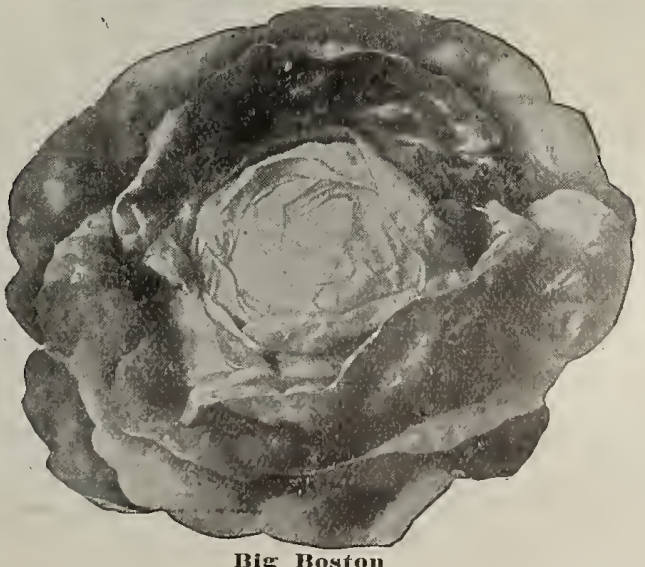


LETTUCE-Continued

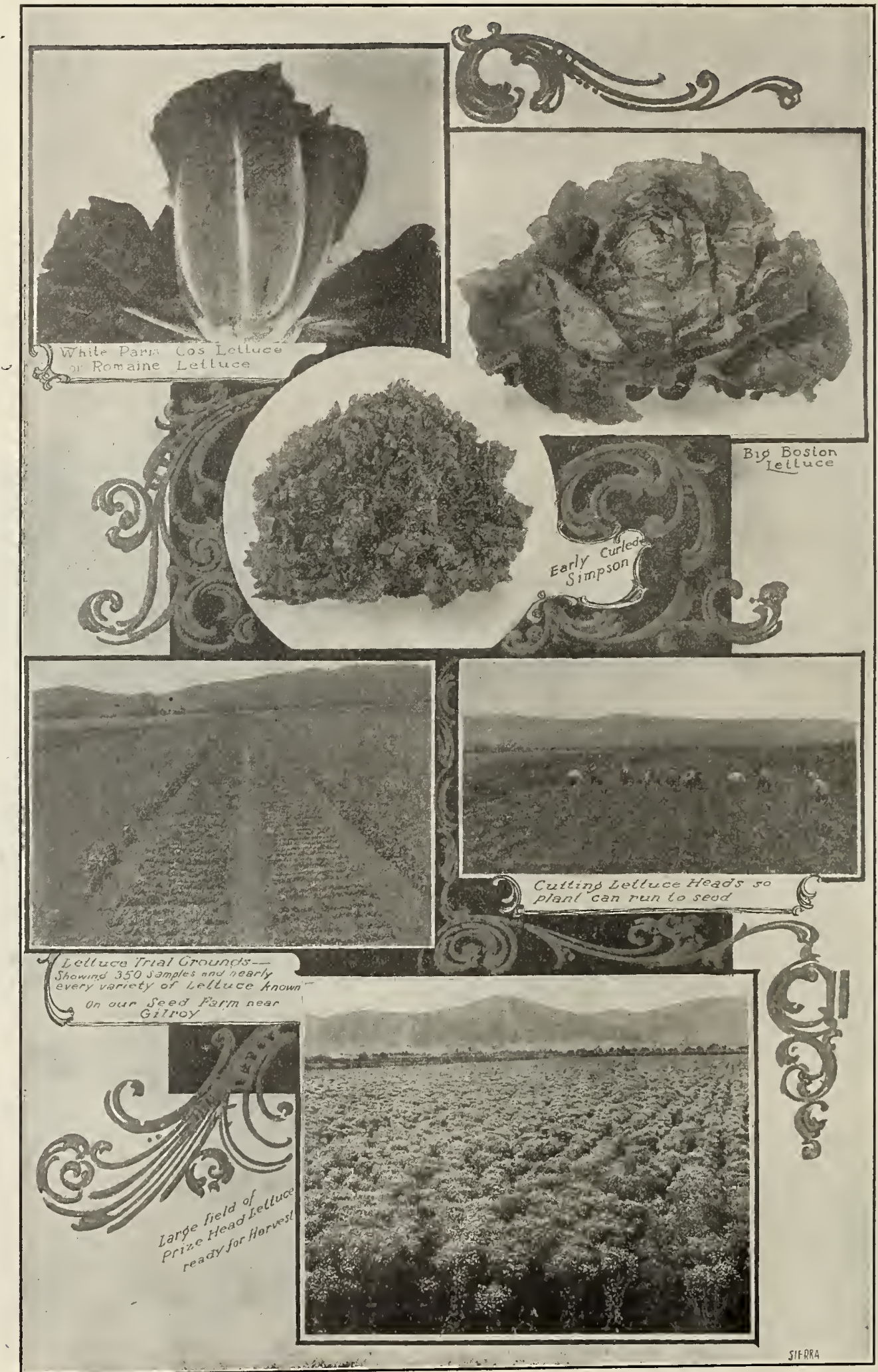

A Page of Lettuce

Illustrating three distinet types al... ... owing some views from our seed farm. 
Mammoth Black Seeded Butter. A very large, green cabbage-heading variety similar to Salamander, but a third larger. Pkt. $5 \mathrm{c} ;$ oz. $15 \mathrm{c} ; \mathrm{1} / 4 \mathrm{Ib} .45 \mathrm{c} ; \mathrm{Ib} . \$ 1.50$

*HANSON. A fine, large-heading variety. Leaves curled on the edges; light yellowish-green in color. The head is crisp and brittle, and flavor excellent. Is the very best house garden variety in existence, and much the flnest variety of its class.

Pkt. 5c; oz. 15c; I/4 Ib. 45c; Ib. $\$ 1.50$

Hubbard's Market. A large cabbage variety, forming a solid head, buttery, and yellow inside and of very fine flavor. Color light green. Is a favorite in some markets. Pkt. 5c; oz. 15c; $1 / 4$ Ib. 40c; lb. $\$ 1.25$ best and truest stock of this variety that can be obtained. It is especially recommended as a garden lettuce for our climate. It heads well, and bears shipping remarkably well, since it revives nicely after wilting. Pkt. $5 \mathrm{c}$; oz. $15 \mathrm{c} ; \mathrm{l} / 4 \mathrm{lb} .45 \mathrm{c}$; Ib. $\$ 1.50$

Royal Summer Cabbage. Same as California Cream Butter, which see for description.

Salamander. One of the most popular varieties for withstanding heat. Medium size, light green, and forms a hard, buttery head of fine quality.

Pkt. $5 \mathrm{c}$; oz. $15 \mathrm{c} ; \mathrm{I} / 4 \mathrm{Ib} .40 \mathrm{c}$; Ib. $\$ 1.25$

Strawberry. Our last season's novelty. A mediumsized variety with hard, compact heads. Brownish-

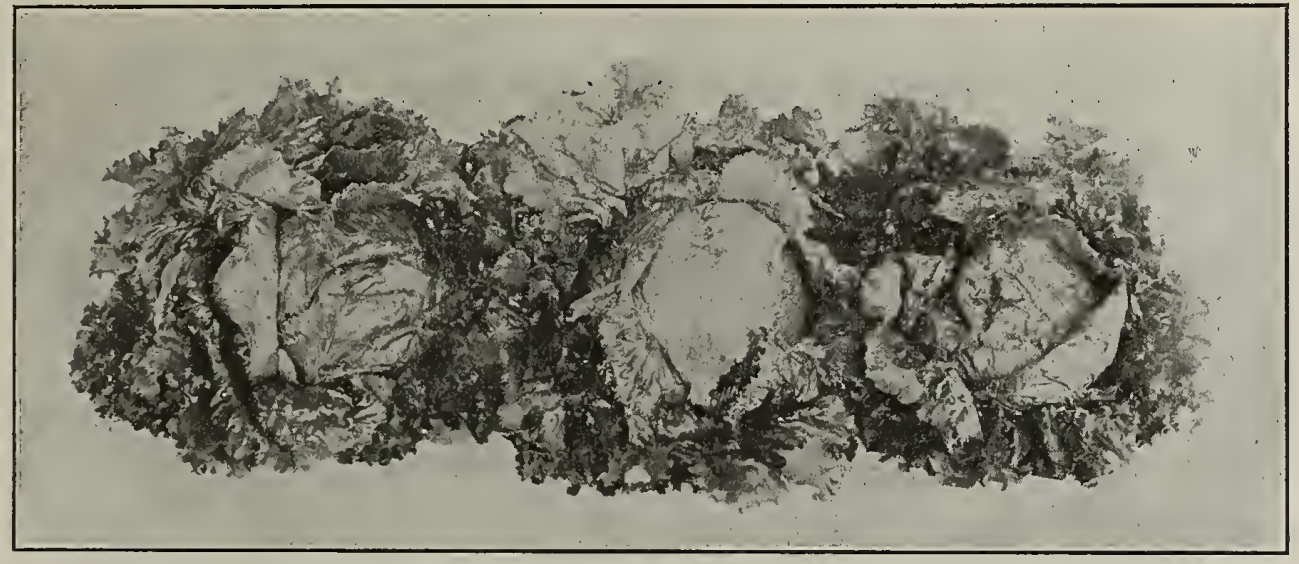

Three average heads of "Hanson"

Iceberg. A large-heading variety; crisp and brittle, and color bright green, lightly tinged with brown on top of the head; leaves curled on the edges.

Pkt. $5 \mathrm{c} ;$ oz. $15 \mathrm{c} ; \mathrm{I} / 4$ Ib. $40 \mathrm{c}$; Ib. $\$ 1.25$

Immensity. A very large heading variety-one of the largest of the cabbage sorts and almost a third larger than California Cream Butter, which it resembles in color and shape.

Pkt. $5 c$; oz. $15 c ; 1 / 4$ Ib. $40 c$; Ib. $\$ 1.25$

May King. A very early new variety, forming fine hard heads within a few weeks after planting. It is medium sized, light green, with buttery but crisp heads. There is just a faint tint of brown on the head. Pkt. 5c; oz. 15c; 1/4 lb. 40c; lb. $\$ 1.50$

New York, or Wonderful. A large, crisp, tight-heading variety. Dark green, curly leaves; head large and of fine quality. Pkt. $5 \mathrm{c}$; oz. $15 \mathrm{c} ; 1 / 4$ lb. $40 \mathrm{c}$; Ib. $\$ 1.25$

*PRIZE HEAD. One of the very best loose-bunching or non-heading varieties. Leaves brown, very curly, and of remarkable fine flavor. Grows quickly and all except the outer row of leaves are very brittle. It is probably the most easily grown lettuce in cultivation. Pkt. $5 \mathrm{c} ;$ oz. $15 \mathrm{c} ; \mathrm{I} / 4 \mathrm{Ib} .40 \mathrm{c} ; \mathrm{Ib} . \$ 1.25$
*PASSION. The most popular variety among California and New Orleans market gardeners. A mediumsized cabbage, butter-heading sort. We have the red on the surface and having pink colored heart.

Pkt. 5c; oz, 20c

The Morse. A large, loose-bunching or non-heading variety, forming a large bunch of leaves, which are very crisp and of fine flavor. In color it is a light green and very attractive.

Pkt. 5c; oz. 15c; 1/4 lb. 40 c; lb. $\$ 1.25$

White Seeded Tennis Ball. This variety is the same as Boston Market, which see for description.

Pkt. 5c; oz. 15c; 1/4 lb. 40 c; lb. $\$ 1.25$

White Summer Cabbaige. The oldest and best known cabbage-heading variety. Forms a medium-sized, hard head of fine quality.

Pkt. $5 c$; oz. $15 \mathrm{c} ; 1 / 4$ Ib. 40 c; Ib. $\$ 1.25$

*WHITE PARIS cos. The best of the Cos or celery varieties. Forms a large, light-green plant, with the head well folded and quite solid. Cos lettuce is also called Romaine, and is very popular with our foreign population, for it is highly prized in England and France, while little known to our own people.

Pkt. 5c; oz. 15c; I/4 Ib. 40 c; lb. $\$ 1.25$

\section{Martynia, or Unicorn Plant}

The young pods are much esteemed for pickles, but must be picked young, since they become very hard and ninty with age. Sow in hills after all danger of frost is over. The plant grows to about five or six feet in diameter, and is very ornamental.

Proboscidea. The common variety. Flowers creamy white with dark-purple throat.

Pkt. $10 \mathrm{c} ;$ oz. $30 \mathrm{c} ; \mathrm{I} / 4$ lb. $85 \mathrm{c} ; \mathrm{Ib}, \$ 3.00$ 


\section{Muskmelon or Cantaloupe}

Melon Muscade

Cantalupen

Muscate

Popone

Plant in hills in rich, moist land, using one ounce to 100 hills, or two or three pounds per acre. Sow the seed after all danger of frost is over, and do not cover deeply. Muskmelons require plenty of water, and if conditions are favorable, will make a strong, vigorous growth, and most varieties bear heavily. It is best to pick off the early runners to make the plant more stocky and thick. Wherever possible, melons should be grown in the home garden, for the charm of a good melon is in getting it fresh from the garden and direct to the table.

Acme, or Early Baltimore. One of the best all-round melons in cultivation, and recommended for its uniform shape and size and fine quality. Is slightly pointed at stem end; somewhat ribbed and coarsely netted. The flesh is thick, green, and very sweet.

Pkt. $5 \mathrm{c}$; oz. $10 \mathrm{c} ; \mathrm{l} / 4$ lb. 30 ; Ib. $\$ 1.00$

Bay View. A standard variety. Fruit large, oblong, heavily ribbed and netted. Flesh light green and of good flavor. $\quad$ Pkt. $5 \mathrm{c}$; oz. $10 \mathrm{c} ; \mathrm{l} / 4 \mathrm{lb} .30 \mathrm{c} ; \mathrm{Ib} . \$ 1.00$

Hackensack, or Turk's Cap. An excellent green-flesh variety, with flattened ends, thick, irregular ribs, and coarse netting. The flavor is sweet and delicious.

Pkt. 5c; oz. 10c; 1/4 Ib. 30c; lb. $\$ 1.00$

Hoodoo. See page 2.

Jenny Lind. Very early and very prolific. Fruit is small, somewhat flattened, deeply ribbed and netted. Flesh green and very sweet.

Pkt. $5 \mathrm{c} ;$ oz. $10 \mathrm{c} ; \mathrm{I} / 4$ Ib. $35 \mathrm{c} ; \mathrm{Ib} . \$ 1.00$

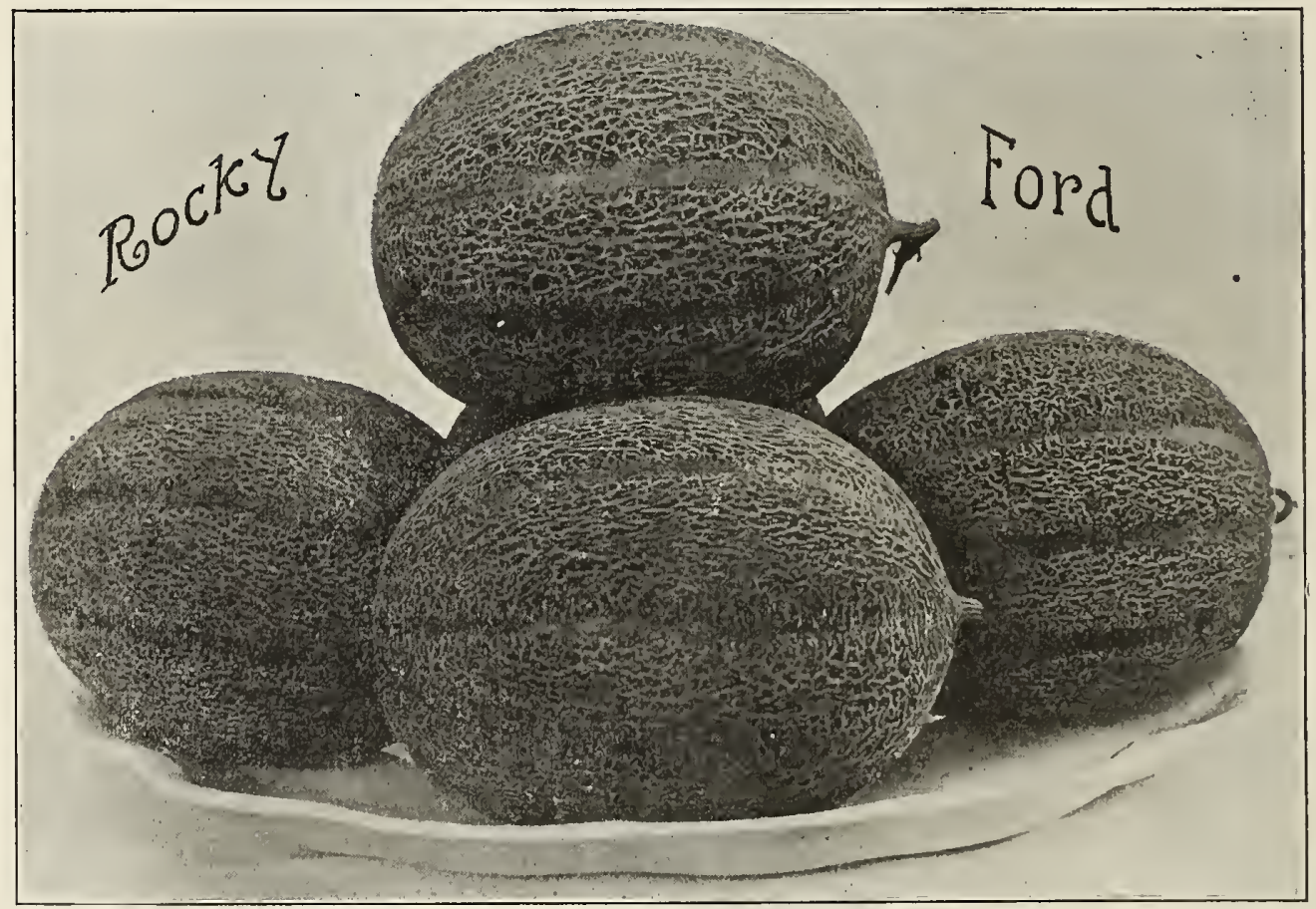

The most largely grown Muskmelon.

Casaba, or the winter melon. This is the sensational novelty of Southern California. See bottom page 10. Pkt. 10c; oz. 25c; 1/4 lb. $75 \mathrm{c}$; lb. $\$ 2.50$

Extra Early Citron. A very early, medium-sized variety. Fruit ball-shaped, skin green, and flesh light green. Very productive; fragrant and of remarkably fine flavor. $\quad$ Pkt. $5 \mathrm{c} ;$ oz. $10 \mathrm{c} ; \mathrm{I} / 4 \mathrm{lb} .40 \mathrm{c} ; \mathrm{Ib} . \$ 1.25$

Emerald Gem. A salmon-fleshed variety of remarkably fine flavor and fine quality. Fruit medium sized, globular, slightly flattened at the ends; skin only slightly netted; very thick, and well ripened close to the rind. Pkt. $5 \mathrm{c} ;$ oz. $10 \mathrm{c} ; \mathrm{I} / 4 \mathrm{lb} .40 \mathrm{c} ; \mathrm{lb} . \$ 1.50$

Extra Early Hackensack. An early variety with almost globular fruit, which is heavily ribbed and heavily netted. Flesh thick, and light green.

Pkt. $5 \mathrm{c} ;$ oz. $10 \mathrm{c} ; 1 / 4$ lb. $35 \mathrm{c} ; 1 \mathrm{lb} . \$ 1.25$
Large Yellow Cantaloupe. Although there are several varieties frequently substituted for this sort, we have a distinct type, and find it very popular with all who have tried it. The fruit is large, oblong, slightly ribbed and coarsely netted. The flesh is light yellowish-green, very sweet, crisp and delicious. $\quad$ Pkt. $5 \mathrm{c}$; oz. $10 \mathrm{c} ; 1 / 4 \mathrm{Ib} .25 \mathrm{c}$; Ib. $90 \mathrm{c}$

Melrose. A fine shipping variety owing to the rather tough skin. Fruit is slightly oval, very much netted but not ribbed. Flesh light green, shading to salmon at seed center, and of very fine flavor.

Pkt. $5 c$; oz. $10 c ; 1 / 4$ lb. 35 c; lb. $\$ 1.00$

Montreal Market. A large-fruited variety, nearly globular with flattened ends. Skin dark green; heavily netted. Flesh light green.

Pkt. 5c; oz. $10 c ; 1 / 4$ lb. $40 c ;$ lb. $\$ 1.50$

Osage, or Miller's Cream. A salmon-flesh variety, larger than "Emerald Gem." Skin dark green, slightly 
netted and ribbed. A favorite variety for the later markets. Pkt. $5 \mathrm{c}$; oz. $15 \mathrm{c} ; \mathrm{I} / 4 \mathrm{lb}$ lb $40 \mathrm{c} ; \mathrm{lb} . \$ 1.25$

Petoskey, or Paul Rose. Excellent market variety with thick, firm, orange-colored flesh. Rather larger than Netted Gem; is slightly oval, ribbed, and heavily netted. Skin light green, changing to a faint golden hue when fully ripe.

Pkt. $5 c$; oz. 10 c; $1 / 4$ lb. 30 c; lb. $\$ 1.00$

*ROCKY FORD, OR NETTED GEM. The most largely cultivated variety in use. Grown in great quantities in Colorado and shipped East in trainloads. Fruit is slightly oval, finely netted, and slightly ribbed. Flesh thick, green, very sweet, and of fine quality.

Pkt. $5 c$; oz. $10 \mathrm{c} ; 1 / 4$ Ib. $30 \mathrm{c} ; \mathrm{Ib} . \$ 1.00$

Small Green Nutmeg. A medium-sized variety with globular fruit. Skin dark green, heavily netted, and slightly ribbed. Flesh thick, green and rather coarse. A desirable variety for hotel and restaurant use. $\quad$ Pkt. $5 \mathrm{c} ;$ oz. $15 \mathrm{c} ; \mathrm{l} / 4 \mathrm{Ib} .40 \mathrm{c} ; \mathrm{Ib} . \$ 1.25$

\section{Watermelon}

\section{Melon d'Eau}

Wassermelon

\section{Zandia}

\section{Melone d'Aqua}

Light, sandy, or gravelly soil is necessary for the best watermelons. They seldom do well on heavy adobe or clay soils, and these lands should be avoided for watermelons as a farm crop. In the garden the soil can be made suitable by spading in each hill some well-rotted manure and sand or loam.

Plant the seed about the first of May, in hills about five feet apart. Use five or six seeds to a hill, and thin out to two plants as soon as the second or third leaf shows. Use about four ounces of seed to 100 hills, or as a farm crop, two to four pounds per acre.

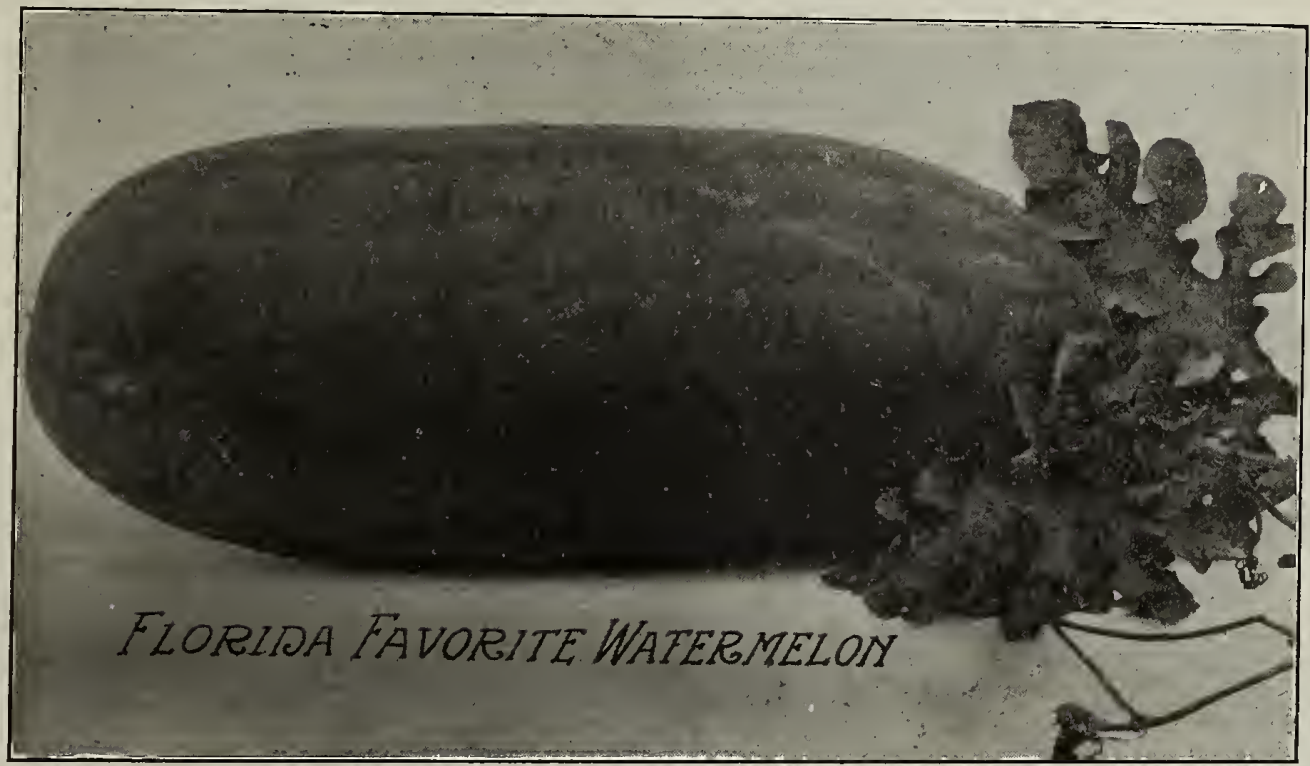

Black Boulder, or Black Diamond. A round, very darkgreen melon with bright-red flesh and black seeds. It is similar to old Black Spanish, but supersedes it in every way.

Pkt. 5c; oz. 10c; 1/4 lb. 20c; lb. 60c

Chilian. A very brittle, thin-skinned variety, of the highest quality, and especially valuable for home garden. It is slightly oblong; the skin is deep rich green, mottled and striped with a still deeper green; the flesh is bright red and the flavor is remarkably fine and sweet. Pkt. 5c; oz. 10c; 1/4 Ib. 30c; Ib. $\$ 1.00$

Citron. A small, globular variety, striped and marbled with light green. Flesh white and solid; seeds red. Used exclusively for pickles and preserves.

Pkt. $5 c ;$ oz. $10 c ; 1 / 4$ lb. $25 c ;$ Ib. $75 c$

Cole's Early. A great favorite for a large area of different climates. Fruit medium sized, oblong, striped and mottled. Flesh bright red, solid, and of fine, sweet flavor. Pkt. $5 c$; oz. $10 c ; 1 / 4$ Ib. 25c; lb. $75 c$

Cuban Queen. An excellent shipping variety of medium to large size, and globular to oval shape. Rind quite thin, flesh bright red and firm. Skin striped with light and dark green.

Pkt. $5 c$; oz. $10 c ; 1 / 4$ lb. $25 c$; lb. $75 c$
Dark Icing. Fruit large, nearly globular. Skin darkgreen, sort of mottled indistinctly with lighter green. Flesh deep pink and of fine flavor.

Pkt. $5 c$; oz. 10 c; $1 / 4$ lb. 25 c; lb. $75 c$

Dixie. A good market variety with large, oblong fruit. Skin striped light and dark green. Rind thin but tough. Flesh bright red.

Pkt. $5 c$; oz. $10 \mathrm{c} ; 1 / 4$ Ib. $25 \mathrm{c} ; \mathrm{Ib} .75 \mathrm{c}$

Fordhook Early. The earliest of all melons and of the finest quality. Fruit almost globular; color deep green with occasional faint stripes of lighter green; flesh bright red and crisp; rind tough, which makes it a good shipping variety.

Pkt. 5c; oz. 10c; 1/4 Ib. 25c; Ib. $75 c$

*FLORIDA FAVORITE. A very large variety with large, oblong fruit and dark-green skin, mottled with a deeper shade. Rind thin, flesh deep red and of fine quality.

Pkt. $5 c$; oz. $10 \mathrm{c} ; \mathrm{I} / 4 \mathrm{Ib} .25 \mathrm{c}$; Ib. $75 \mathrm{c}$

*GEORGIA RATTLESNAKE, OR GYPSY. A large oblong variety, with decided stripes of light and deep green. Rind tough, and it is one of the best shipping melons. Flesh bright red and of good quality.
Pkt. $5 c$; oz. 10c; $1 / 4$ Ib. 25 c; Ib. $75 c$ 
WATERMELONS-Continued

Halbert Honey. A large, oblong variety of the best quality. Is especially sweet in flavor, crisp and brittle, and well ripened to a very thin rind.

Pkt. 5c; oz. 10c; 1/4 lb. 30c; lb. $\$ 1.00$

Ice Cream. A popular home-market variety. The fruit is oblong, with dark green skin. Flesh deep pink.

Pkt. $5 \mathrm{c} ;$ oz. $10 \mathrm{c} ; \mathrm{1} / 4 \mathrm{lb}$. 25c; lb. $75 \mathrm{c}$

lceberg. In general appearance this variety resembles Kolb's Gem, but the skin, which is dark green with markings of a lighter shade, is darker in Iceberg, and shows a spot of bright yellow where the fruit rests on the ground. The rind is thin and the flesh deep red. It is the best dark-colored shipping variety in use. Pkt. 5c; oz. 10c; $1 / 4 \mathrm{Ib} .25 \mathrm{c}$; Ib. $75 \mathrm{c}$

*KLECKLEY SWEETS, OR MONTE CRISTO. A VEry desirable variety for the home garden or near-by markets. Will not stand shipping, as the rind is thin and brittle. Fruit medium sized, oval, and skin dark green; flesh bright red and very sweet. It is the very sweet, honey-like flavor that makes it especially distinct from all other varieties.

Pkt. 5c; oz. $10 \mathrm{c} ; 1 / 4$ lb. $25 \mathrm{c}$; lb. $75 \mathrm{c}$

Mclver's Sugar. One of the best shipping melons, similar to Georgia Rattlesnake, being conspicuously striped and a good shipper. Flesh is of fine quality, rich and sweet in flavor.

Pkt. $5 \mathrm{c} ;$ oz. $10 \mathrm{c} ; 1 / 4$ lb. $25 \mathrm{c} ; \mathrm{lb} .75 \mathrm{c}$

Kolb's Gem. The well-known shipping variety. The fruit is large, thick, and oval, with flattened ends. Skin striped with light and dark green. Flesh bright red. $\quad$ Pkt, 5c; oz, 10c; 1/4 lb. 25c; Ib. $75 \mathrm{c}$

Mountain Sweet. A good home-garden variety and an old favorite. Fruit large and oval; skin green, and uesh bright red. Pkt. 5c; oz. 10c; 1/4 lb. 25c; lb. 75c

Sweet Heart. A very productive and fine shipping variety. Fruit large, oval, with thin but firm rind. Flesh bright red, solid, and sweet. Skin light mottled green. Pkt. 5c; oz. 10c; 1/4 lb. 25c; lb. 75c

The Lodi, or San Joaquin. Well-known and popular California variety, grown on an immense scale in San Joaquin Valley and shipped to all parts of the Pacific Coast. Fruit large and oblong; skin green and slightly mottled; rind thin but tough; flesh bright red and sweet; seeds white.

Pkt. 5c; oz. 10c; 1/4 Ib. 25c; Ib. 75 c

\section{Mushroom Spawn \\ Seta}

Blanc de Champignon

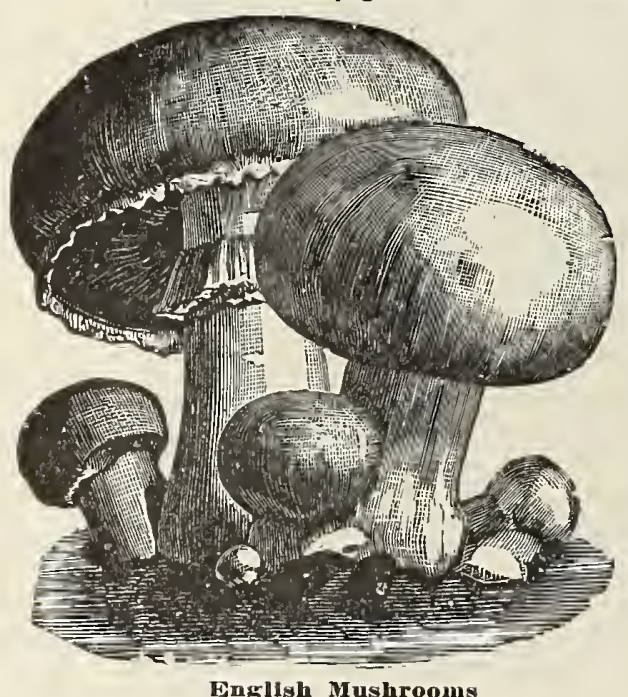

Fungo Pratajolo

\section{Cultural Directions}

Ten pounds will spawn about ten feet square. Mushrooms can be grown in any dark room or cellar where the temperature can be kept at from 50 to 70 degrees. From some old pasture procure good rich soil, and to every bushel of this soil add two bushels of fresh horse manure. Of this well-mixed compound prepare a bed, say four feet wide. Put down a thin layer and pound it down hard, and go on until you have a bed twelve or eighteen inches thick. As soon as the temperature of the bed falls from 75 to 50 degrees, the spawn may be inserted in pieces about the size of a walnut about two inches deep and six inches apart. Cover with loamy soil about two inches deep and beat it down evenly and firmly. Finish off with a covering of clean hay, about a foot thick, and the work is done. If the temperature is right, in six or eight weeks you may expect mushrooms. The beds will continue bearing from twenty to thirty days. After the first crop is gathered spread over the bed an inch of fresh soil, moisten with warm water, and cover with hay as before. The main conditions in mushroom-growing are proper and uniform temperature and very rich soil.

English Mushroom Spawn. It comes in pressed bricks weighing about twenty ounces. Per brick, 35c, postpaid; by express, per brick 20c; 10 lbs. $\$ 1.50$.

\section{Mustard}

\section{Moutarde}

Mostaza

The leaves of these varieties of mustard, as here listed, make excellent greens of sharp, pungent flavor, and are cooked the same as spinach or beet leaves. Sow the seed in drills early in the spring and at frequent intervals throughout the summer to secure a constant supply of fresh greens. Mustard is hardy and is easily grown. One ounce will sow fifty feet of row.

Chinese. A very hardy, broad-leaved variety. Leaves are thick and deeply savoyed, with broad white midrib. $\quad$ Pkt. 5c; oz. 10c; 1/4 lb. 15c; Ib. 40c

Fordhook Fancy. A very handsome variety with dark green foliage. Leaves very finely curled on the edges. Plant medium sized.

Pkt. 5c; oz. 15c; 1/4 Ib. 25c; Ib. 90c
*GIANT SOUTHERN CURLED. A large variety, form. ing a great mass of beautiful leaves, which are ruffled and finely curled on the edges. Hardy and vigorous, and very highly recommended.

Pkt. 5c; oz. 10c; 1/4 Ib. $15 c$; Ib. $50 c$

White English. A light-green variety with tender leaves. Seed light yellow.
Per oz. $5 \mathrm{c} ; 1 / 4 \mathrm{lb} .10 \mathrm{c} ; \mathrm{lb} .30 \mathrm{c}$

\section{Nasturtium}

The green seed of nasturtium has a sharp, pungent flavor, and when pickled makes an excellent condiment It is also valuable as a flower and serves a double purpose in the garden. It is very sensitive to frost and should not be planted before April 15th. The tall or climbing variety requires a fence or trellis to climb on, and the seed may be planted in a row, using two ounces to 100 feet.

Tall Mixed. The most prolific and easily glown variety.

Pkt. $5 c$; oz. $10 \mathrm{c} ; 1 / 4$ lb. $25 \mathrm{c}$; lb. $75 \mathrm{c}$ 


\section{Okra, or Gumbo}

Gombaud

Safran

Quimbombo

Ocra

The long, tender pods of okra are very delicious when sliced and cooked in soups. While this is its chief use, It is also boiled and served like other classes of vegetables. The tall sorts should be planted in hills about a foot apart, using about one ounce to 100 hills. The dwarf sorts may be planted in hills or in rows about three feet apart. Plant in any good soil about April 1st. The pods should be gathered when very young, as they are then vers tender.

DWARF GREEN. An early, dwarf, and prolific variety with thick, green pods.

Pkt. 5c; oz. 10c; 1/4 Ib. 20c; Ib. 60c

slender, deep green, and of fine quality.

Pkt. $5 c$; oz. $10 c ; 1 / 4$ Ib. $20 c$; Ib. $60 c$

'PERKINS' MAMMOTH LONG POD. A dwarf-growing very early and prolific variety. Pods are long,

White Velvet. A medium-sized variety, bearing long, smooth, white pods, which are very tender.

Pkt. 5c; oz. 10c; 1/4 Ib. 20c; Ib. $60 c$

\section{Onions}

Oignon

Zwiebein

Cebolla

Cipollo

The best onions are grown on low, sandy, or mucky lands, with natural moisture, and plenty of it. Higher lands can be used if irrigated, providing the land is rich and very well worked before planting the seed. Onions do not follow a hay or grain crop to good advantage, since the soll lacks nitrogen and humus. $A$ piece of land contemplated for onions should be planted to beans, peas, or some other vegetable crop one or two years.

On high lands the seed should be sown in December or early in January, while on low lands any time from February 1st to March 10th will do, depending on the condition of the weather. Sow in rows from twelve to sixteen inches a part, using four to five pounds of seed. In irrigating onions, it is important that the land never be allowed to get dry, for a check in the growth will either force the plant to run to seed or will make stiff necks. In the house garden plant early in drills, using one ounce to 250 feet of row.

The onion seed crop this year is very short, owing to the loss of a large area of onions growing for seed, by the floods last winter.

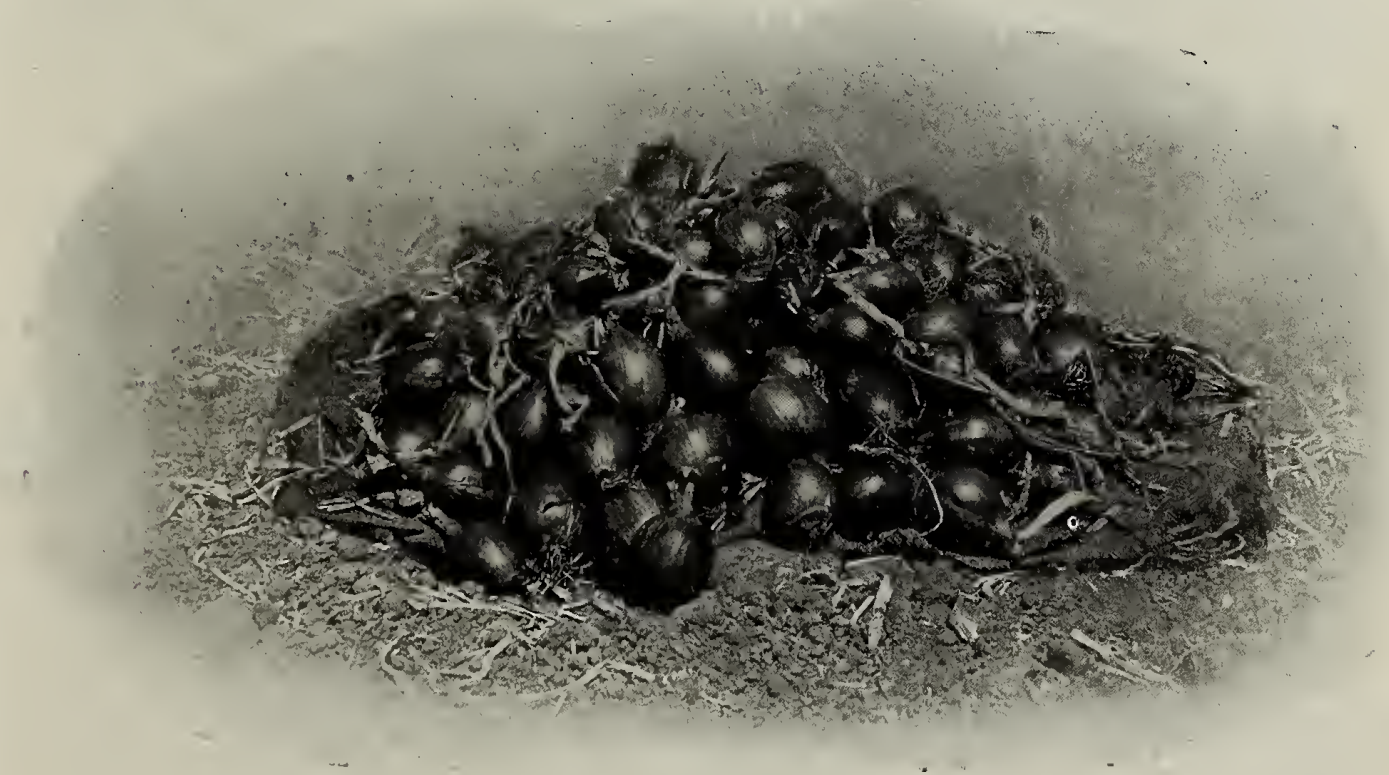

"Ohio Yellow Globe" Onions

Australian Brown. An early and very hardy variety which does especially well in the South. Should be planted early, on low, wet grounds to get large bulbs. The skin is thick and the color is a rich brown. Is especially noted as a long keeper, as it keeps well into spring, and much longer than other varieties.

$$
\text { Pkt. 5c; oz. 20c; 1/4 Ib. 60c; Ib. } \$ 2.25
$$

Californla Early Red. A variety much used for very early onions. If the seed is sown in beds in August and set in the fleld in November or December, good market onions can be had in May. It is not a goodkeeping variety, but is of very mild flavor and of fine quality. Is very much esteemed as a green onion before the bulb is formed.

Pkt. $5 c$; 0z. 25 c; $1 / 4$ lb. 65 c; lb. $\$ 2.25$

El Paso. A large white globe Italian variety. The grain is rather coarse and the flavor mild. It is not a good winter sort, but is unsurpassed as a garden variety.

Pkt. 5c; oz. 25c; 1/4 lb. 65c; lb. $\$ 2.25$
Extra Early Pearl. A very early variety with white skin, rather coarse grain and mild flavor. In shape it is flat and is unsurpassed for early sets or home-made pickles. $\quad$ Pkt. $5 \mathrm{c} ;$ oz. $25 \mathrm{c} ; 1 / 4$ lb. $65 \mathrm{c} ; \mathrm{lb} . \$ 2.25$

Extra Early Barletta. Extremely early variety. Seed planted in February will form ripe onions the last of July. Is a white onion, forming small bulbs about one inch in diameter. Valuable for home-made pickles. $\quad$ Pkt. $5 \mathrm{c} ;$ oz. 25c; $1 / 4 \mathrm{lb} .65 \mathrm{c}$; Ib. $\$ 2.25$

Extra Early Golden Globe, or Australian Extra Early Yellow Globe. A handsome and valuable yellow globe-shaped variety. It is very early and extremely hard and firm, and almost as good in long-keeping qualities as Australian Brown. It runs very uniform in shape, is of good average size, and perfectly globular. The skin is rich orange yellow and the flesh is quite strong and fine grained.

Pkt. $5 c ; 0 z .20 c ; 1 / 4$ Ib. 60 c; Ib. $\$ 2.00$ 
oxroxs-Continued

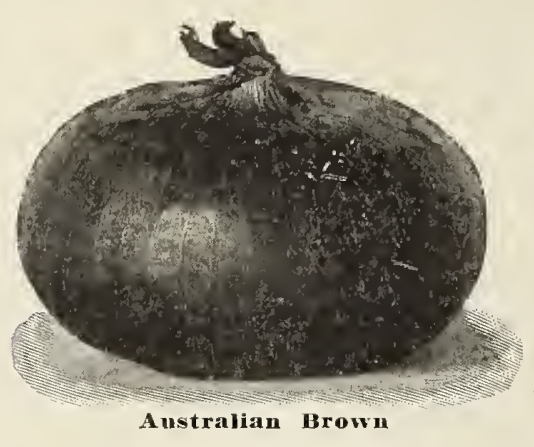

Extra Early Red Flat. A very early, flat variety with dark purplish-red skin. Forms a hard bulb with good keeping qualities.

Pkt. 5 c; oz. 20 c; $1 / 4$ Ib. 60 c; Ib. $\$ 2.00$

Mammoth Silver King. An early, large, white, flat variety. Is not a keeping sort nor a good shipping variety, but is valuable for home use and near-by markets. Is very mild and of fine flavor.

Pkt. $5 c$; oz. 25 c; $1 / 4$ Ib. $65 c$; lb. $\$ 2.25$

Morse Brown Globe. A fine, large, globe-shaped sort, of a rich, seal-brown color. It ripens uniformly and nearly every plant makes a solid, hard bulb. It has all the long-keeping characteristics of Australian Brown, and is one of the very best varieties for market. $\quad$ Pkt. $5 \mathrm{c}$; oz. $25 \mathrm{c} ; 1 / 4 \mathrm{lb} .75 \mathrm{c}$; Ib. $\$ 2.50$

*OHIO YELLOW GLOBE. The best of the yellow-globe varieties. The skin is bright, glossy, orange-yellow; and the flesh is white, and fine grained. The bulbs are remarkably uniform in size and shape, and being firm and hard possess fine keeping and shipping qualities .

Pkt. $5 c$; oz. $25 c ; 1 / 4$ !b. $75 c ;$ Ib. $\$ 2.50$

Prizetaker. A very large globe-shaped variety with lightyellow skin and white flesh of mild flavor. It is a heavy cropper and a fairly good keeping onion, and is very popular as a market variety. Individual bulbs sometimes weigh four pounds and very often two or three pounds.

Pkt. $5 c ;$ oz. $25 \mathrm{c} ; \mathrm{l} / 4$ lb. $75 \mathrm{c}$; Ib. $\$ 2.50$

Southport Yellow Globe. A fine, orange-yellow, globeshaped variety. Is a heavy cropper, and forms a long-keeping, hard bulb.

Pkt. $5 \mathrm{c} ;$ oz. $20 \mathrm{c} ; 1 / 4 \mathrm{Ib} .75 \mathrm{c}$; Ib. $\$ 2.50$

*RED WETHERSFIELD. The best-known and most widely-used red variety. In shape it is flattish, but thick, with very firm flesh. Is hard, and an excellent keeper, as well as a heavy cropper. The color is a bright purplish-red.

Pkt. 5c; oz. 20 c; 1/4 Ib. 60 c; Ib. $\$ 2.25$

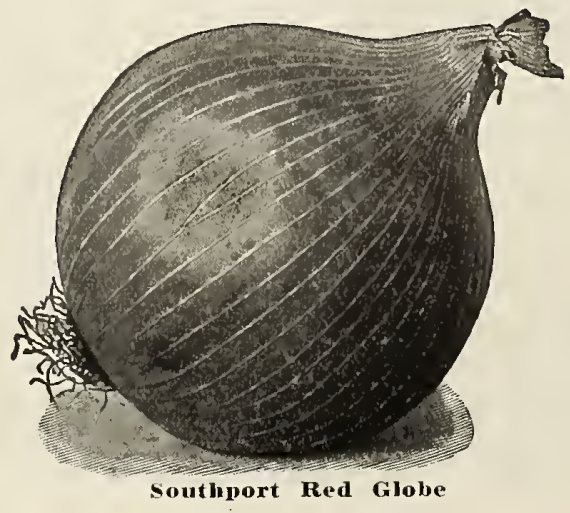

Red Bermuda. A very early, flat variety, used largely in the South for planting in the fall and marketing in the spring. Is of mild flavor and a good shipper, but not a winter-keeping variety. The color is a pale red. The best stock is imported from Teneriffe, Canary Islands, and we offer only this stock.

Pkt. 5c; oz. 25 c; 1/4 Ib. 75 c; Ib. $\$ 2.50$

Southport White Globe. A pure white globe-shaped variety. Forms handsome hard onions with wax-like, pearl-white flesh. Is used a great deal for green onions owing to the clear, white stem.

Pkt. $5 \mathrm{c} ;$ oz. $35 \mathrm{c} ; \mathrm{I} / 4$ Ib. $\$ 1.00 ; \mathrm{Ib} . \$ 3.50$

Southport Red Globe. A large, globe-shaped, bright purplish-red variety. Is a late sort and an excellent keeper. A very handsome variety and of fine quality.

Pkt. 5 c; oz. 20 c; $1 / 4$ lb. 60 c; Ib. $\$ 2.25$

*YELLOW DANVERS FLAT. The best-known and most generally used flat, yellow onion. Is the most hardy of all varieties for California and yields the surest and largest crops. Color bright orange-yellow; flesh white and firm. A good keeper, fairly early, and of good size. $\quad$ Pkt. 5c; oz. 20c; 1/4 Ib. 60c; lb. $\$ 2.25$

Yellow Dutch, or Strasburg. The most popular and best variety for set purposes. Is similar to the Yellow Danvers Flat in shape, color and size, but as a set onion it has the quality of ripening down earlier and more uniformly. Pkt. 5c; oz. 20c; 1/4 Ib. 60c; lb. $\$ 2.25$

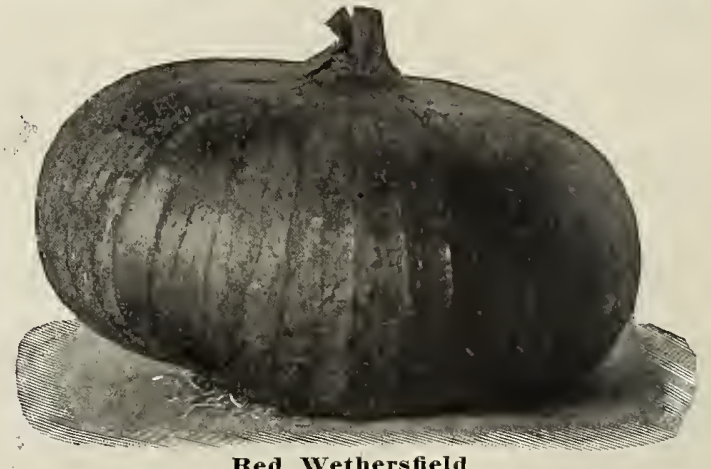

Red Wethersfield

Yellow Globe Danvers. The popular yellow globe onion for market and shipping purposes. Is almost ballshaped, but a trifle flattened at both ends. It is a heavy cropper, and a good, firm, hard-fleshed variety.

Pkt. $5 c ;$ oz. $25 \mathrm{c} ; 1 / 4$ lb. $75 \mathrm{c} ;$ Ib. $\$ 2.50$

White Bermuda. A very early variety, used largely in the south as an early market onion, when the seed is sown in the fall and the onions harvested in the spring. It is mild and of particularly fine flavor. The color is a pinkish-straw color, and the shape is flat. The seed we offer is grown in Teneriffe, Canary Islands, and is a fine pure strain.

Pkt. $5 c$; oz. 25 c; $1 / 4$ Ib. $75 c$; Ib. $\$ 2.50$

*WHITE PORTUGAL, OR SILVERSKIN. The bestknown and most largely used white onion. Is flat on the bottom and thick toward the top. Very hard and firm and an excellent keeper. Is largely used for white onion sets as well as for market onions and pickles. Pkt. $5 \mathrm{c}$; 0z. $30 \mathrm{c} ; \mathrm{I} / 4 \mathrm{lb}$. 75c; Ib. $\$ 3.00$

White Italian Tripoli, A large, globe-shaped variety, with clear, white skin and pearl-white flesh. Of mild, sweet flavor. Not a good keeping onion, but much esteemed as a garden variety.

Pkt. 5c; oz. 25c; 1/4 lb. 65c; lb. $\$ 2.25$

White Queen. A very early white onion. Rather small and does not keep well. Is of fine, mild flavor, and largely used for home-made pickles.

Pkt. $5 c ;$ oz. $25 c ; 1 / 4$ lb. 65 c; Ib. $\$ 2.25$ 


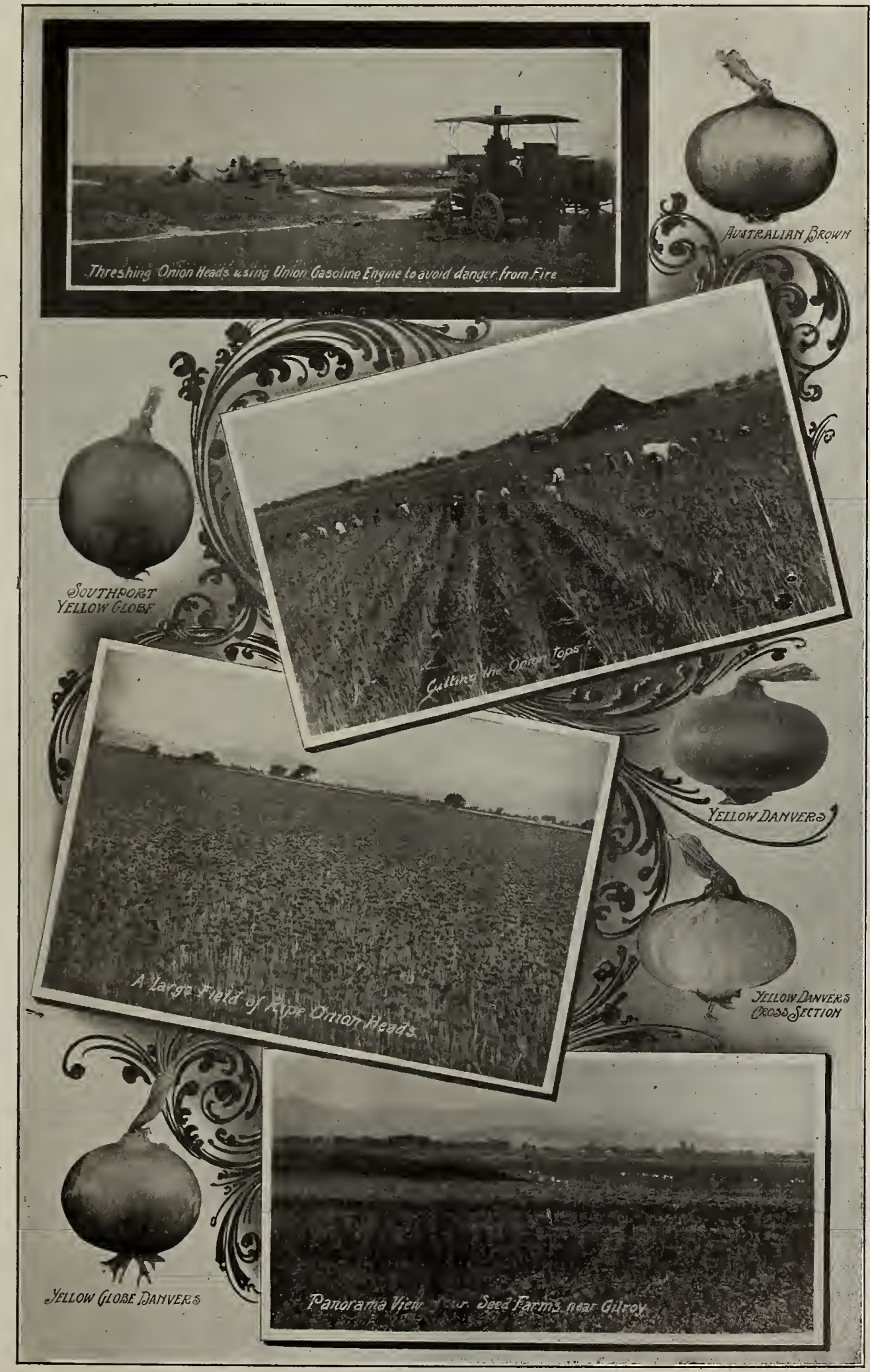

A Page of onions

Illustrating some of the leading varieties; also some field views of our seed farms near Gilroy.

We do not exaggerate in the least when we make the statement that we are the largest orowers of onion seed in the world. 


\section{ONIONS-Continued}

\section{Onion Sets}

Onion Sets are miniature onion bulbs grown from seed and are so formed by sowing 50 to 75 pounds of seed per acre. Good sets are those of very small size and well ripened.

Plant near the surface, in drills 12 inches apart and 4 inches between the sets. When raised from sets, the onions can be used in the green state or may be ripened off for large onions, in which case they are fully six

weeks earlier than when raised from seed. Prices are subject to market fluctuations as the season advances.
Postage on Onion Sets is 10 cents per pound additional.

Brown or Yellow Onion Sets. Per Ib. 20c. White Onion Sets. Per Ib. 25c.

Large quantities are furnished at prevailing market prices. Please write for quotations.

Garlic. Per Ib. 25c.

\section{Parsley}

Perejil

Persil

Petersilie

Used for garnishing dishes of meat or cooked in sou plants in for garnishing dishes of meat, or cooked in soups. A few plants in the garden will yield sufficient for a family, providing the in drills early in spring, using one-fourth of an ounce to $100 \mathrm{feet}$.

Champion Moss Curled. A very finely curled, bright-green and very ornamental variety.

Pkt. $5 c$; oz. $10 \mathrm{c} ; 1 / 4$ lb. 20c; lb. $60 \mathrm{c}$

Hamburg, or Turnip Rooted. A plain-leaved variety, forming a long, thick, edible root. $\quad$ Pkt. $5 \mathrm{c} ;$ oz. $10 \mathrm{c} ; \mathrm{V} / 4 \mathrm{lb} .20 \mathrm{c} ; \mathrm{lb} .50 \mathrm{c}$

Plain or single. A very hardy variety, resembling a wild plant. The leaves are flat and not curled.

Pkt. $5 \mathrm{c}$; oz. $10 \mathrm{c} ; \mathrm{1} / 4$ lb. $20 \mathrm{c}$; Ib. $50 \mathrm{c}$

*DOUBLE CURLED. A curled variety, very hardy and easy to grow. Deep, rich green, and by many preferred to the extremely curly varieties.

Pkt. $5 \mathrm{c}$; oz. $10 \mathrm{c} ; 1 / 4$ lb. $20 \mathrm{c} ; \mathrm{lb} .60 \mathrm{c}$

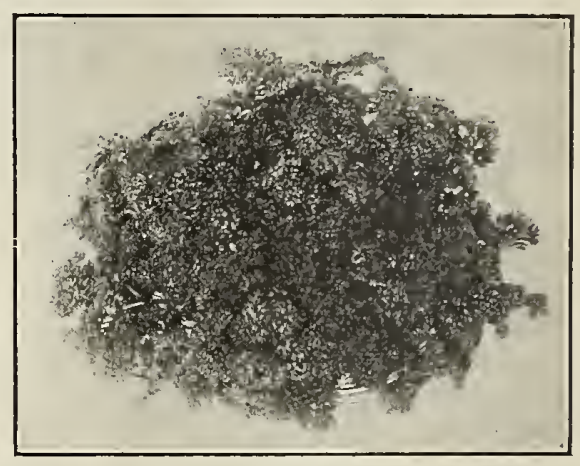

Moss Curled Parsley

*EXTRA TRIPLE CURLED. Very finely curled variety of dark-green color. One of the best varieties for all purposes.

\section{Parsnips}

\section{Panais}

A well-known vegetable for table use. It is also a very good stock food and quite as nutritious as carrots, not grow. A sandy soil is preferred, since the roots Sow the seed in the spring in drills, using one-fourth ounce to Early Short Round French. A flat, turnip-shaped variety. of rather coarse grain, and not as good quality as the long varieties, but early and easy to dig in stiff, hard soil. Pkt. 5c; oz. 10c; 1/4 lb. 20c; Ib. 50c

*HOLLOW CROWN. A variety with a hollow or cupshaped top, where the leaf stem begins. The most popular and best variety for all purposes. Skin smooth and white, and flesh tender, while the root grows eighteen to twenty inches long. The best part of it is contained in the first eight inches from the top.

Pkt. $5 c$; oz. $10 c ; 1 / 4$ Ib. 20c; Ib. 50c

Long Smooth. A very long variety with full crown. Very smooth, white skin.

Pkt. $5 \mathrm{c} ;$ oz. $10 \mathrm{c} ; \mathrm{I} / 4$ Ib. $20 \mathrm{c}$; Ib. $50 \mathrm{c}$

\section{Peas}

\section{Pois \\ Erbsen \\ Chicaroso Guisantes \\ Pisello}

Peas are quite hardy, and for very early market can be planted in the fall in protected places, and ripe pea. can be had in February. They require

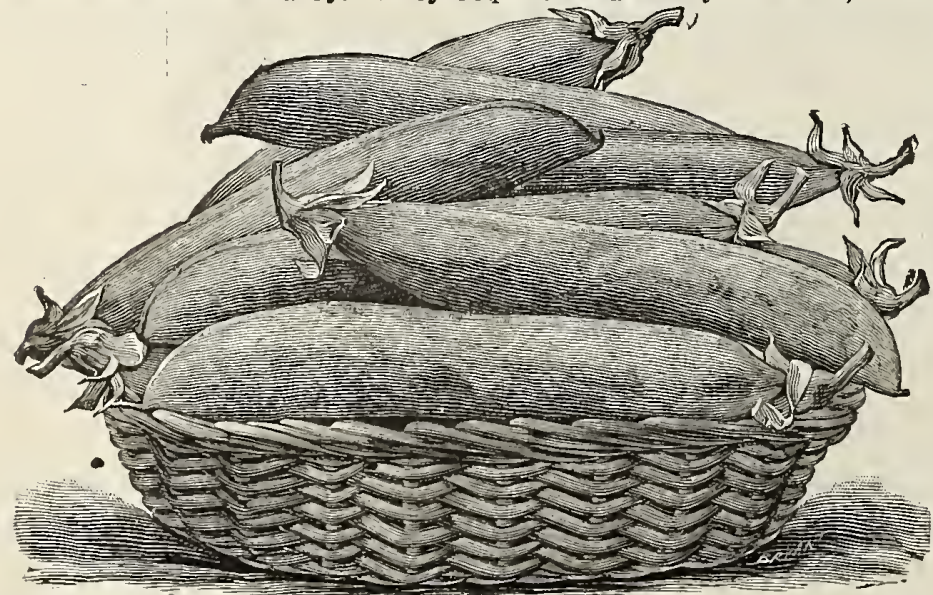

A Basket Full of "Strategem" Peas much to vine, and do not bear heavily. The seed needs to be planted thick, using from 150 to 200 pounds per acre for seed or vegetable crop, or one pound for sixty feet of row.

The dwarf varieties can be planted in rows twelve to eighteen inches apart, and the tall ones three feet. By using the various classes of peas and by making several sowings of each, good peas can be had for a long season. In the garden the pods should be kept picked, as the plants will then continue to bear longer.

Express or freight charges are not prepaid. Write us for special quotations on large quantities.

\section{Peas-Extra Early Varieties}

*ALASKA, OR EARLIEST OF ALL. A very early, tall variety, with smooth, small peas of good quality, and short, well-filled pods. Its fruit ripens practically all at one time, and is very popular with canners, who always desire to make but one cutting. Pkt. 10c; lb. 25c, postpaid. By express or frelght, lb. $15 \mathrm{c} ; 10$ lbs. $\$ 1.00 ; 100$ lbs. $\$ 7.50$. 
*american wonder. A dwarf or short-vine variety, bearing short, thick, well-filled pods which are a rich dark green. It bears well, is easily grown, and very early. The peas are of especially fine flavor, and it is the best dwarf variety for all purposes. The dried peas are wrinkled. Pkt. 10c; Ib. 25c, postpaid. By express or freight, Ib. $15 \mathrm{c} ; 10 \mathrm{lbs} . \$ 1.25 ; 100 \mathrm{lbs}$. $\$ 10.00$.

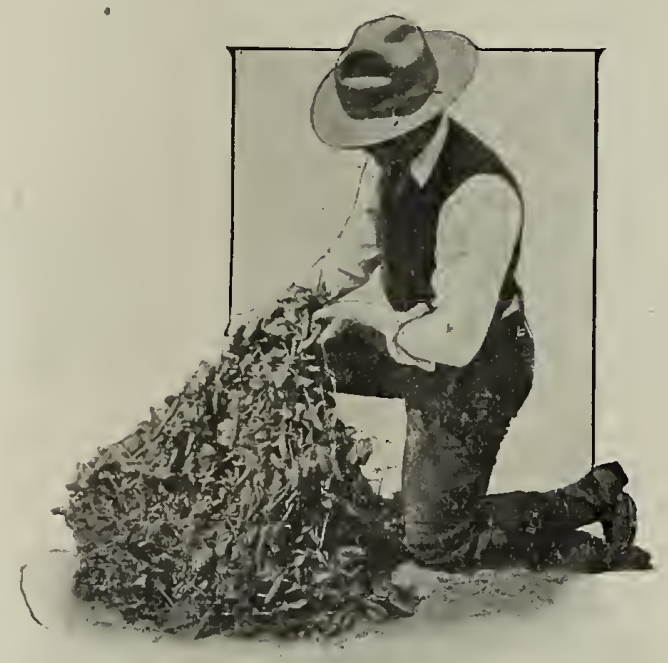

A plant of "American Wonder" Peas

First and Best. One of the earliest tall varieties, with smooth, round peas, which ripen almost at one time. Pods straight, short, and well filled. Of fair quality. Pkt. $10 \mathrm{c}$; Ib. $25 \mathrm{c}$, postpaid. By express or freight, lb. $15 \mathrm{c} ; 10$ lbs. $\$ 1.00 ; 100$ lbs. $\$ 7.00$.

Gradus, or Prosperity. One of the very best early varieties. Is a tall variety, growing about three feet high and bears very long pods, which are pointed, and well filled with large, sweet, and very fine wrinkled peas. The foliage and pods are light green, and the plant is not very hardy. Pkt. 10c; lb. 30c, postpaid. By express or freight, Ib. 25c; $10 \mathrm{lbs}$. $\$ 2.00 ; 100$ lbs. $\$ 15.00$.

Burpee's Best Extra Early. We offer the introducer's prize strain. This is very much the best early pea of the smooth-seed varieties, is very much sweeter than Alaska and also earlier. The vines make a very quick growth, about eighteen to twenty inches in length, and the pods ripen practically all at one time. Pkt. 10c; lb. 25c, postpaid. By express or freight, lb. $15 \mathrm{c} ; 10$ lbs. $\$ 1.00 ; 100$ lbs. $\$ 8.00$.

McLean's Little Gem. A good, dwarf, wrinkled variety, growing about eighteen inches high. Pods about three inches long and well filled with large peas. Pkt. 10c; Ib. 25c, postpaid. By express or freight, lb. $15 \mathrm{c} ; 10$ lbs. $\$ 1.00 ; 100$ lbs. $\$ 9.00$.

Nott's Excelsior. The most popular dwarf, wrinkled variety for the home garden or market garden. The vines are larger and more productive than American Wonder and the peas are of especially flne flavor and good quality. Pkt. 10c; lb. 25c, postpaid. By express or freight, Ib. $15 \mathrm{c} ; 10$ lbs. $\$ 1.25 ; 100$ lbs. $\$ 10.00$.

*PREMIUM GEM. The best and most popular dwarf, wrinkled variety, especially with market gardeners. It grows about fifteen inches high and bears goodsized pods, which are filled with six to eight peas of especially fine, sweet flavor. Pkt. $10 \mathrm{c}$; lb. $25 \mathrm{c}$, postpaid. By express or freight, lb. $15 \mathrm{c} ; 10$ lbs. $\$ 1.00$; 100 lbs. $\$ 9.00$.
Thomas Laxton. A fine, early, tall variety similar to Gradus, but more hardy and not quite so early. Is also a little darker in color and taller, but has the same fine, large pods and fine color. Pkt. 10c; lb. $35 \mathrm{c}$, postpaid. By express or freight, lb. $25 \mathrm{c} ; 10 \mathrm{lbs}$. $\$ 1.50 ; 100$ lbs. $\$ 12.50$.

\section{Peas Second Early Varieties}

Abundance. A tall, branching variety bearing mediumsized pods with large peas of good quality. It ripens evenly, and is used largely by canners. Pkt. 10c; lb. 25c, postpaid. By express or freight, lb. 15c; 10 lbs. $\$ 1.00$; 100 lbs. $\$ 8.00$.

McLean's Advancer. A good, tall variety with wrinkled peas of very fine quality. Is especially productive and very popular with market gardeners. Pkt. 10c; lb.. 25c, postpaid. By express or freight, lb. $15 \mathrm{c} ; 10$ lbs. $\$ 1.00 ; 100$ lbs. $\$ 8.00$.

Everbearing. A tall. wrinkled variety bearing broad pods well filled with large peas of good quality. Pkt. $10 \mathrm{c}$; lb. 25c, postpaid. By express or freight, lb. $15 \mathrm{c} ; 10$ lbs. $\$ 1.00 ; 100$ lbs. $\$ 8.00$.

\section{Peas-Late Varieties}

Champion of England. One of the most popular, tall, wrinkled varieties. Is very prolific and hardy, and the peas are of especially fine, rich quality. Pkt. $10 \mathrm{c}$; Ib. $25 \mathrm{c}$, postpaid. By express or freight, lb. 15c; 10 lbs. $\$ 1.00 ; 100$ lbs. $\$ 8.00$.

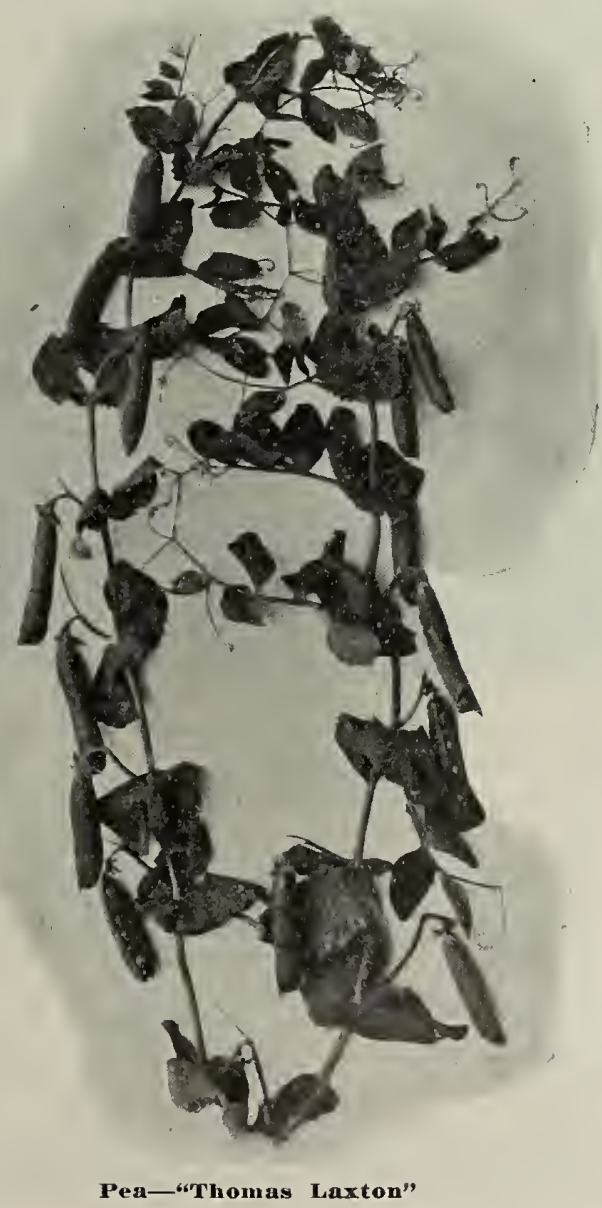




\section{PEAS-Continued}

Horsford's Market Garden. A tall variety of medium height; very prolific; peas small and wrinkled, but pods well filled. Dark green and hardy and very popular as a canning variety. Pkt. 10c; lb. 25c, postpaid. By express or freight, Ib. 15c; 10 lbs. $\$ 1.00 ; 100$ lbs. $\$ 8.00$.

*STRATAGEM. A semi-dwarf variety with large leaves and large pods. The peas are dark green, wrinkled, and of good quality. Pkt. 10c; lb. 25c, postpaid. By express or freight, Ib. $15 \mathrm{c} ; 10$ lbs. $\$ 1.25 ; 100$ lbs. $\$ 11.00$.

Black-Eyed Marrowfat. The best of the marrowfat varieties. Tall, hardy, and productive. Pkt. 10c; Ib. 20c, postpaid. By express or freight, lb. 10c; $10 \mathrm{lbs}$. $80 \mathrm{c} ; 100$ lbs. $\$ 7.00$.

Large White Marrowfat. A very tall hardy variety. Very productive, but of inferior quality. Pkt. 10c; Ib. 20c, postpaid. By express or freight, Ib. 10c; 10 lbs. 80 c; 100 lbs. $\$ 7.00$.
Melting Sugar. A tall variety, bearing long, flat, brittle pods, which are cut or broken and cooked like string beans. Is a delicious vegetable, and should be better known and more generally used. Pkt. 10c; lb. $35 \mathrm{c}$, postpaid. By express or freight, lb. $25 \mathrm{c} ; 10 \mathrm{lbs}$. $\$ 1.50$.

*TELEPHONE. One of the latest varieties. Is tall and vigorous, with enormous pods, bearing large, wrinkled peas of remarkably fine quality. A popular home-garden and market variety. Pkt. 10c; lb. $25 \mathrm{c}$, postpaid. By express or freight, Ib. $15 \mathrm{c} ; 10 \mathrm{lbs}$. $\$ 1.25 ; 100$ lbs. $\$ 10.00$.

*YORKSHIRE HERO, or ALAMEDA SWEETS. A very hardy and prolific, semi-dwarfed, wrinkled variety. The peas are large and of fine quality and the pods, which are broad and medium sized, remain in condition for a long time. It bears immense crops, both of pods and dried peas, and is the variety most largely planted by gardeners. Pkt. $10 \mathrm{c}$; lb. 20c, postpaid. By express or freight, lb. $10 \mathrm{c}$; $10 \mathrm{lbs} .80 \mathrm{c}$; 100 lbs. $\$ 6.50$

\section{Piment}

\section{Peperone}

There are varied uses for pepper's, and while they are more popular in the South among the Spanish and Mexican people, they are used very largely by all who like strong, hot condiments. The several varieties are used for stuffing when green, for pickles, for pulverizing when dry, and for soups, etc. Our selection of varieties includes all of the very best.

Peppers do best in hot climates, but can be grown quite successfully in most places. They require very rich soil. The seed germinates slowly and should be started in boxes, and the young plants transplanted after all danger of frost is over.

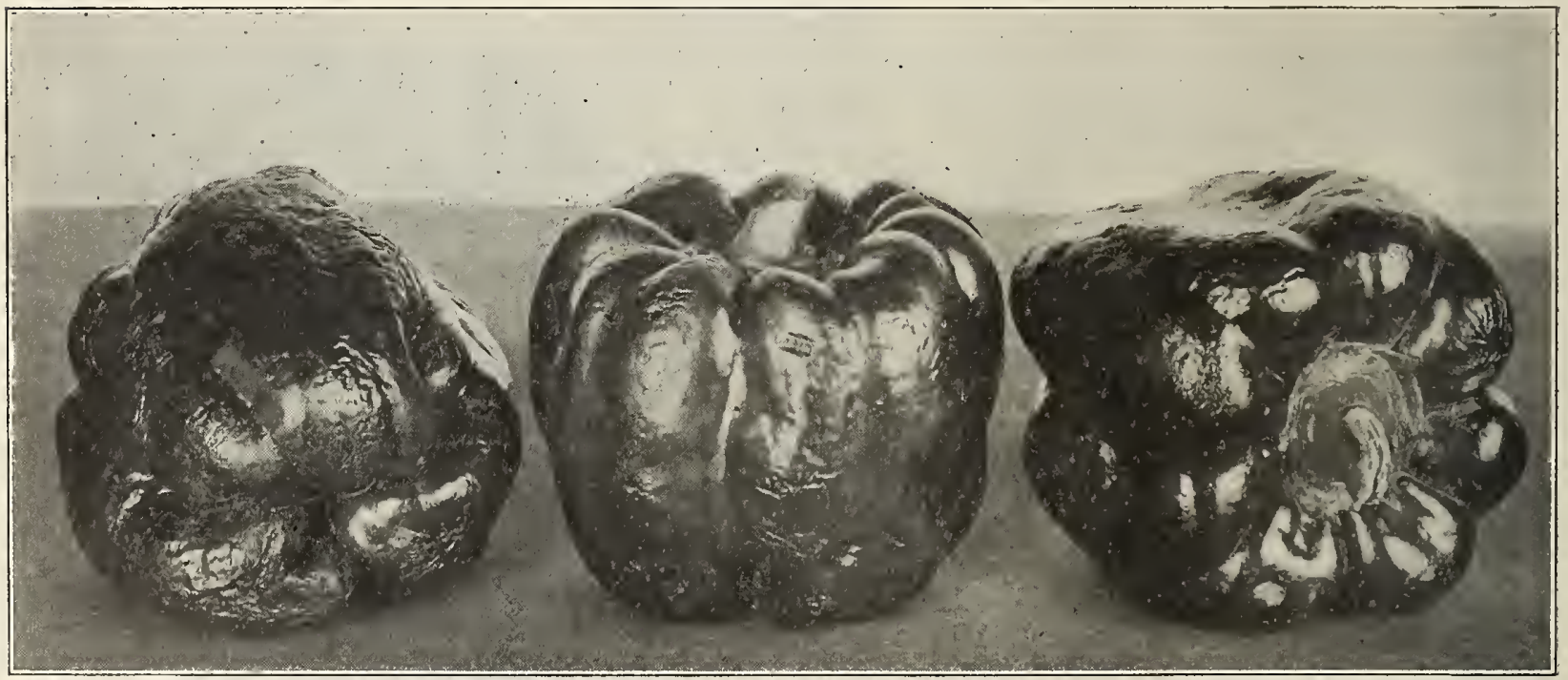

Large Bell or Bull Nose Peppers-best for stufling

*CHINESE GIANT. A very large, deep-red variety, very thick and blunt. It is fully twice as large as Large Bell, or Bull Nose, being four or five inches thick at the top and about six inches long.

Pkt. 10c; oz. 50c; 1/4 Ib. $\$ 1.60 ;$ Ib. $\$ 5.50$

Golden Dawn. A short, thick variety, similar to Large Bell, or Bull Nose, in shape, but a rich golden yellow, with a mild sweet flavor.

Pkt. $5 c$; oz. $25 \mathrm{c} ; 1 / 4$ lb. $75 \mathrm{c} ;$ Ib. $\$ 2.50$

Large Squash. An early variety, bearing large, flat, or tomato-shaped fruit, which is bright red when fully ripe.

Pkt. $5 c ;$ oz. 25 c; 1/4 lb. 75 c; Ib. $\$ 2.50$

* LARGE BELL, or BULL NOSE. The most popular variety for stuffing. Fruit large, round and blocky, and about three inches long and two inches thick. The color is deep green when fruit is young, but when fully ripened it is a rich, glossy blood-red. Plant grows about two feet high.

Pkt. $5 \mathrm{c} ;$ oz. $25 \mathrm{c} ; 1 / 4$ Ib. $75 \mathrm{c} ;$ Ib. $\$ 2.50$

*LONG RED CAYENNE. A strong, pungent variety, having long, pointed fruit, which is bright scarlet when ripe. A well-known and popular variety.

Pkt. $5 \mathrm{c}$; oz. $25 \mathrm{c} ; 1 / 4$ lb. $75 \mathrm{c} ;$ Ib. $\$ 2.50$

Red Cherry. An ornamental as well as useful variety, the plant being tall and bearing profusely, small, bright red fruit. The fruit is small, round, very hot, and is largely used for pickles.

Pkt. $5 c ; 0 z .25 c ; 1 / 4$ Ib. $75 c ;$ Ib. $\$ 2.50$ 
Red Chili. A rather small, bright-red variety about two inches long, and pointed. The pods are used in making chili sauce, and are very pungent and hot.

Pkt. $5 c ;$ oz. 25 c; $1 / 4$ lb. $75 c ;$ lb. $\$ 2.50$

Ruby King. A popular variety of the Bell, or Bull Nose type. The fruit is large, bright, glossy-red, and the flavor is mild and sweet. A desirable variety for slicing in salads and for stuffing.

Pkt. $5 c$; oz. $25 c ; 1 / 4$ Ib. $85 c$; lb. $\$ 3.00$
Sweet Mountain, or Spanish Mammoth. A very. popular variety with some market gardeners. It is a late variety, bearing large, thick fruit, which is frequently eight inches long and two or three inches in diameter. When mature, it is a deep, glossy red, and the flavor is mild and sweet.

Pkt. $5 c ;$ oz. 25 c; 1/4 Ib. $75 c ;$ Ib. $\$ 2.50$

\section{Pumpkin}

\section{Potiron}

While pumpkins are of strong growth, they. will not stand frost, and cannot be planted until about April 15th. A moderately rich soil is sufficient for good pumpkins. Plant in hills about six to eight feet apart. Three to four pounds of seed will plant an acre, and one ounce will plant 100 hills. Do not plant near squashes or melons, as they are likely to mix.

If large quantities are wanted, write us for special price.

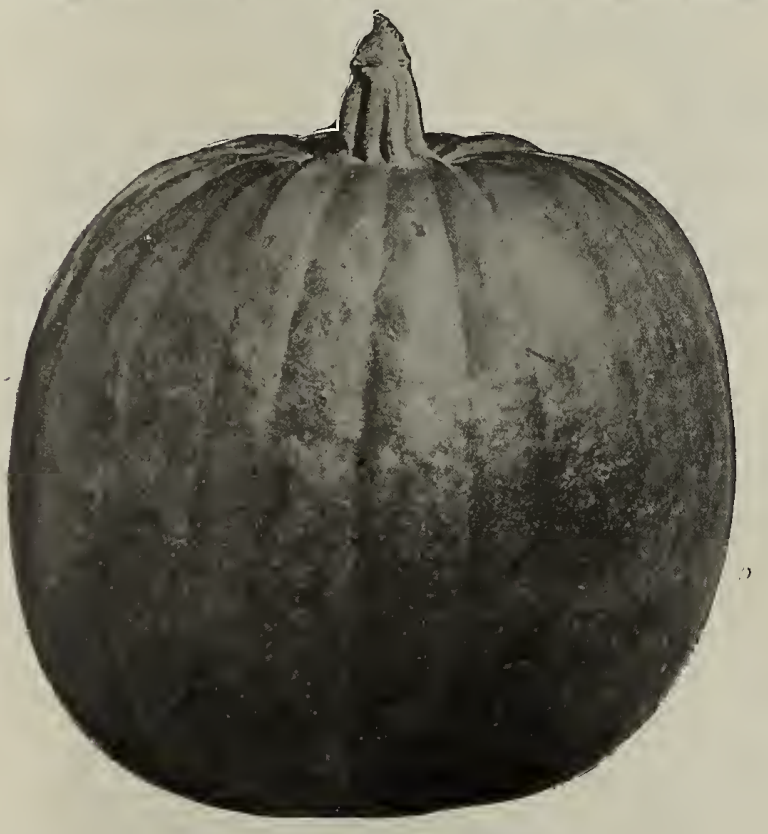

Big Tom Pumpkin
Calabaza

Zucca

*CONNECTICUT FIELD. A fine, large, orange-colored variety used for field culture and stock feeding. The skin is smooth and ribbed and the flesh is brittle and sweet.

Pkt. $5 \mathrm{c} ;$ oz. $10 \mathrm{c} ; 1 / 4$ Ib. $20 \mathrm{c} ; \mathrm{Ib} .50 \mathrm{c}$, postpaid

*COMMON FIELD. The well-known, ordinary pumpkins, largely used for stock feeding. The fruit is variously colored in yellow, drab, red, and orange, and varies also in size, but is usually very large. Is a heavy cropper and very easily grown.

Pkt. 5c; lb. 30c, postpaid. By express or freight, lb. 20 c; 10 lbs. $\$ 1.75 ; 100$ lbs. $\$ 14.00$.

Large Cheese, or Kentucky Field. A very large, flattened variety, averaging ábout two feet through. When ripened the skin is a rich cream color. Flesh yellow and of fine quality.

Pkt. 5c; oz. $10 c ; 1 / 4$ lb. 20c; lb. 50c, postpaid

Mammoth King, or Big Tom. The best large pumpkin in use. Forms immense globular melons, flattened a little at the end. Skin reddish yellow in color and flesh rich orange.

Pkt. 5c; oz. 10c; 1/4 lb. 20c; Ib. 50c

Mammoth Golden Cushaw. One of the best stock-feeding varieties. Is a solid, yellow Crooknecked sort, and is nearly all flesh, having a very small seed cavity.

Pkt. $5 c$; oz. $10 c ; 1 / 4$ lb. $30 c$; lb. $60 c$, postpaid

Pie Pumpkin. A small, round, yellow sort, with fine, pinkish netting. Flesh is thick, sweet, and of excellent quality.

Pkt. $5 c$; oz. $10 c ; 1 / 4$ Ib. $30 c$; Ib. $\$ 1.00$, postpaid

*SMALL SUGAR. A small, round variety of excellent quality. The flesh is rich yellow, very thick and sweet, and the skin is deep orange. We recommend this variety as the very best for pies.

Pkt. $5 \mathrm{c} ;$ oz. $10 \mathrm{c} ; \mathrm{l} / 4$ Ib. $30 \mathrm{c} ; \mathrm{Ib} . \$ 1.00$, postpaid

\section{Radish}

Radis

Rettig

\section{Rabanitos}

\section{Ravanello}

Being a root crop, good brittle radishes require light, well-worked soil, made very rich and mellow to insure quick growth. If permitted to grow slowly, they become tough and pithy. They are easy to grow and frequent plantings will insure a constant supply for the table. Use two-thirds ounce for 100 feet of row, and thin the very young plants somewhat to prevent crowding. Summer varieties can be sown all spring and well into summer. Winter varieties, however, require some time to mature, and the seed should be planted in August and September for good radishes in November and December.

Brightest Long Scarlet. A very showy, long variety. Is thick at the shoulder and tapering. Bright rose scarlet with distinct white tip.

Pkt. $5 \mathrm{c}$; oz. $10 \mathrm{c} ; 1 / 4$ lb. $25 \mathrm{c}$; lb. $75 \mathrm{c}$

Chartier. A very long variety and larger in diameter and general size than Long Scarlet. Keeps hard and crisp longer than most varieties, and is an excellent garden sort. Color bright rose with lighter colored tip. Pkt. $5 \mathrm{c}$; oz. $10 \mathrm{c} ; 1 / 4$ Ib. 25c; lb. $75 \mathrm{c}$

Cincinnati Market. An early and quick-growing long variety, which keeps hard and crisp for a long time. A favorite market garden variety. Color, crimson. Pkt. $5 c ;$ oz. $10 \mathrm{c} ; 1 / 4$ Ib. $25 \mathrm{c} ; \mathrm{Ib} .75 \mathrm{c}$
Chinese Rose Winter. A bright scarlet winter variety. About 4 inches long and stump-rooted. Matures two or three weeks earlier than the Chinese White Winter and like it is firm and crisp and does not grow pithy until it runs to seed.

Pkt. $5 \mathrm{c}$; oz. $10 \mathrm{c} ; 1 / 4$ lb. 25c; lb. $90 \mathrm{c}$

* CHINESE WHITE WINTER, or CELESTIAL (or Cal. Mammoth White Winter). The well-known and popular winter variety. Clear white, about 4 inches long and half stump-rooted. Keeps firm and crisp until it runs to seed. Is a good cooking variety, and when cooked the flavor resembles turnip.

Pkt. $5 c$; oz. $10 \mathrm{c} ; 1 / 4$ Ib. $25 \mathrm{c} ;$ Ib. $90 \mathrm{c}$ 
RADISHES-Continued

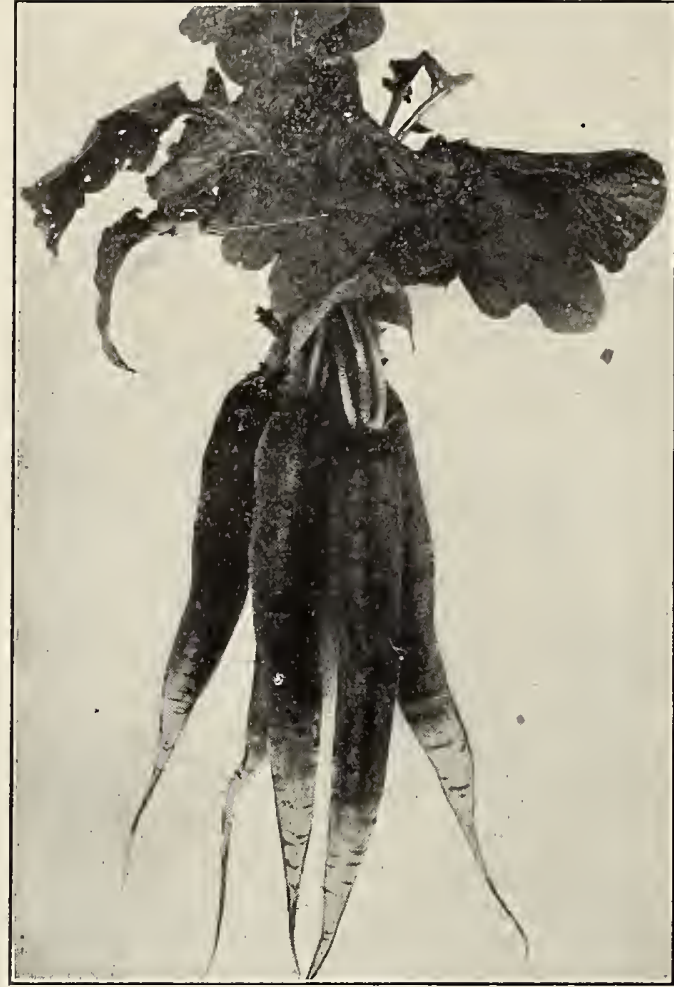

"Long Scarlet"

Crimson Giant Forcing. A new variety which will be a popular market and home garden variety, since it matures very early and remains firm and crisp much longer than other short varieties. Color, rose carmine with white tip. It is top-shaped.

Pkt. $5 c$; oz. 10 c; $1 / 4$ Ib. 25c; Ib. $75 c$

Early Round Dark Red, or Prussian Globe. A bright scarlet, turnip-shaped variety. Early, quick growing, and a handsome radish.

Pkt. $5 c$; oz. 10c; 1/4 lb. 25c; Ib. $75 c$

Early Scarlet Turnip. A valuable variety for forcing or outdoor culture. Is a small, turnip-shaped variety, and in color entirely crimson.

Pkt. 5c; oz. 10c; I/4 Ib. 25c; Ib. 75c

*EARLY SCARLET GLOBE. A popular forcing variety owing to its very quick growth and fine, bright scarlet color. Shape, a trifle oblong.

Pkt. $5 c$; oz. $10 \mathrm{c} ; \mathrm{I} / 4$ Ib. $25 \mathrm{c}$; Ib. $75 \mathrm{c}$

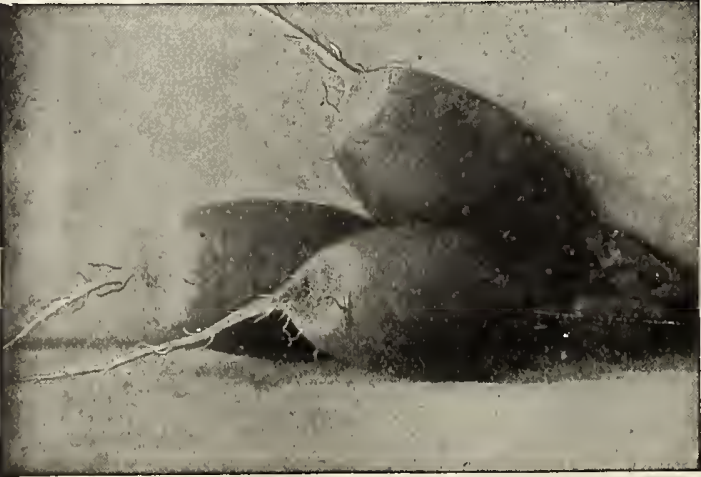

French Breakfast Radish

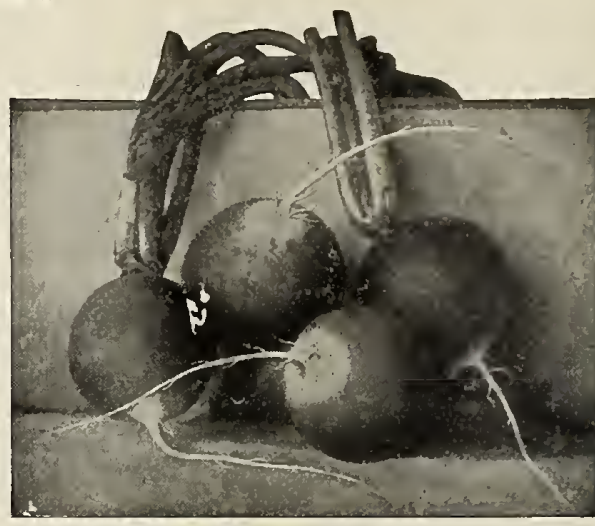

Searlet Turnip White Tipped Radish

Early White Turnip. A very quick-growing, small, turnip-shaped variety. Color, clear white; very mild flavor, and valuable for forcing.

Pkt. $5 c$; oz. 10c; 1/4 lb. 25c; Ib. $85 \mathrm{c}$

French Breakfast. A popular variety for market or forcing. It is about two inches long and decidedly stump-rooted. Color, bright rose with bottom of root and the tail pure white.

Pkt. 5c; 0z. 10c; 1/4 Ib. 25c; Ib. $75 c$

Golden Globe. Quite a large top-shaped variety with yellow skin, and solid, white flesh. Is not a quickgrowing variety, but retains its solidity a long time after maturity. Pkt. 5c; oz. 10c; 1/4 Ib. 25c; Ib. 75c

Half Long, or Olive-Shaped. The variety most largely used by gardeners in California. It is about 3 inches long with half stump-root and sloping top. Color, carmine. Quick growing and hardy.

Pkt. $5 c ;$ oz. 10 c; $1 / 4$ Ib. 20 c; lb. $60 c$

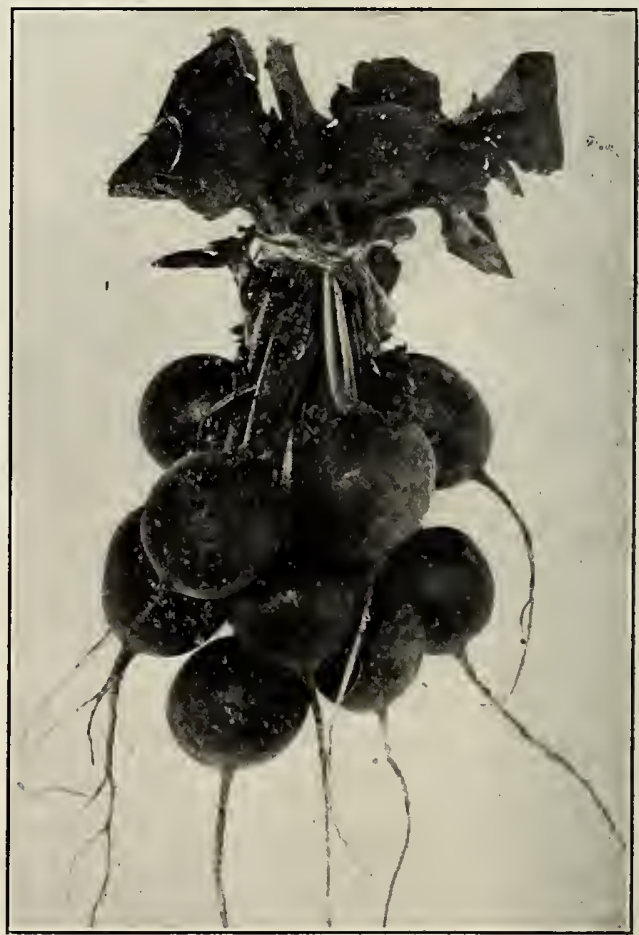

Early "Scarlet Globe" 
Half Long Deep Scarlet. A shorter, olive-shaped variety, with half stump-root and sloping top. Color, bright scarlet. Valuable for forcing.

Pkt. 5c; oz. 10c; 1/4 lb. 25c; Ib. 750

*ICICLE. A handsome white variety, about 5 inches long, with sloping top and pointed root. Quick growing, brittle, and mild in flavor.

Pkt. 5c; oz. 10c; 1/4 lb. 25c; lb. $75 c$

Long Black Spanish. A winter variety with almost black skin and white flesh. Roots about six inches long. $\quad$ Pkt. $5 \mathrm{c}$; oz. $10 \mathrm{c} ; \mathrm{l} / 4 \mathrm{lb} .25 \mathrm{c} ; \mathrm{Ib} .75 \mathrm{c}$

*LONG SCARLET (short top). The best known and most popular long variety. Color, bright carmine, and flesh brittle and firm. About 6 inches long, the top growing out of the ground about one inch.

Pkt. 5c; oz. $10 \mathrm{c} ; \mathrm{I} / 4 \mathrm{lb} .20 \mathrm{c} ; \mathrm{lb} .60 \mathrm{c}$

Long White Japanese. A winter variety, growing frequently 2 feet long and about 3 inches in diameter. Skin, white; flesh, solid and tender, and very pungent. A staple article of diet with the Japanese, who use it both green and dried.

Pkt. $5 c$; oz. 10 c; I/4 lb. $25 c$; lb. $75 c$
Round Black Spanish. A winter variety with black skin and white flesh. It is top-shaped or almost globular.

Pkt. $5 c$; oz. $10 \mathrm{c} ; 1 / 4$ lb. $25 \mathrm{c}$; lb. $75 \mathrm{c}$

*SCARLET TURNIP, WHITE TIPPED (or Rosy Gem). One of the most popular and attractive short varieties. It is globe-shaped, bright rose carmine, with bottom and tip clear white. Stems and leaves small. Very valuable for forcing as ell as for the house garden and market.

Pkt. 5c; oz. 10c; I/4 lb. 25c; lb. 90c

White Strasburg. A large, white variety for late summer use. Rather thick at the shoulder and tapering to about 5 inches in length. Keeps firm and solid a long time. Pkt. 5c; oz. 10c; 1/4 lb. 25c; lb. 75c.

White Vienna (or Lady Finger). A very fine, long, white variety, quick growing, and ready for use when very young. The flavor is mild and sweet.

Pkt. 5c; oz. 10c; 1/4 Ib. 25c; Ib. $75 c$

Wood's Early Frame. A very early, long variety, resembling Long Scarlet, but earlier and desirable for forcing. $\quad$ Pkt. $5 \mathrm{c} ;$ oz. $10 \mathrm{c} ; \mathrm{l} / 4 \mathrm{lb} .25 \mathrm{c} ; \mathrm{lb} .75 \mathrm{c}$

\section{Rhubarb}

Rhubarbe

Rhabarber

Ruibarbo

Rabarbaro

A rich, sandy soil, wet but well drained, is best for rhubarb. While it is frequently propagated from seed, only a percentage comes true, but it is cheaper to grow from seed and discard untrue plants. The popular method, however, is to use young plants propagated from the crown. Set plants three feet by six. The best stems are produced the second year, but it continues to produce for severai years. When the blossom stalk appears, it should be cut back well into the ground.

Myatt's Victoria. The variety most generally in use.

It comes fairly true from seed.

Seed-Pkt. $5 c ;$ oz. $15 c ; 1 / 4$ Ib. $40 c ;$ Ib. $\$ 1.50$

Roots-15c each, $\$ 1.50$ per dozen.

Crimson Winter. The new variety, which has become

\section{Salsify, or Vegetable 0yster \\ Haferwurzel \\ Ostra Vegetal}

Salsifis

Sassefrica

The salsify root, which grows about twelve inches long and one inch in diameter, is becoming a very popular vegetable. When cooked, it has a distinct flavor of the oyster, and may be served in a great variety of ways. A
loose, light soil, especially sandy loam, is desirable for a long, smooth root. In stiff soils the roots are usually uneven and hard to dig. Use three-fourths ounce for 100 feet of row, and thin to one or two inches to prevent crow ding.

*MAMMOTH SANDWICH ISLAND. The improved, large-rooted variety, growing about 12 inches long and being from 1 to 2 inches thick.

Pkt. $5 \mathrm{c} ;$ oz. $20 \mathrm{c} ; 1 / 4 \mathrm{lb} .65 \mathrm{c} ; \mathrm{lb} . \$ 2.25$

\section{Sorrel}

The large leaves, when cooked like spinach, make a very palatable vegetable. In California it grows Iuxuriantly, spreads rapidly from the root, and becomes an obnoxious weed unless given attention. A confined location in the garden is therefore recommended.

Large Leaved French. The variety having the largest leaves, and therefore the most desirable.

Pkt. 5c; oz. $15 c ; 1 / 4$ Ib. $40 c ;$ lb. $\$ 1.25$

\section{Spinach}

Epinard

or A
field a field crop for the market garden, use 8 pounds of seed per acre. For the home garden use one-half ounce for 100 feet of row.

*BLOOMSDALE SAVOY. The variety most generally used in the East, and especially throughout the South for shipping. Leaves large, round, and thick very much savoyed and rich deep green. One of the earliest varieties. Seed, round.

Pkt. $5 c$; oz. $10 \mathrm{c} ; 1 / 4$ lb. $15 \mathrm{c}$; lb. $35 \mathrm{c}$

Long Standing. A deep green variety with rather elongated, smooth leaves. Seed, round. Stands a long time without running to seed.

Pkt. 5c; oz. 10c; 1/4 lb. 15c; lb. $40 c$

Victoria. A long-standing variety with round, slightly savoyed leaves. Deep green and hardy. Forms good, edible leaves early and continues to produce leaves for a long period.

Pkt. $5 c ;$ oz, 10c; 1/4 lb. $15 c ;$ lb. $40 c$
New Zealand. A plant with thick, fleshy texture and soft crystalline leaves. Is not like the ordinary spinach in appearance, but it is used in the same way.

Pkt. $5 c ;$ oz. $10 \mathrm{c} ; \mathrm{l} / 4 \mathrm{lb}$. $30 \mathrm{c} ; \mathrm{lb} . \$ 1.00$

*PRICKLY. The variety commonly used for market in California. Is very hardy and easily grown; bears large, smooth leaves, which are shaped like an arrow point. Color, bright green. Seed, irregular, with 3 or 4 sharp points.

Pkt. $5 \mathrm{c}$; oz. $10 \mathrm{c} ; \mathrm{I} / 4$ lb. $15 \mathrm{c} ; \mathrm{lb} .30 \mathrm{c}$

Round, Thick Leaved. A large-leaved, bright green variety. Leaves rather smooth and rounded at the top. A good variety for late spring and summer. Seed, round. Pkt. $5 \mathrm{c}$; oz. $10 \mathrm{c} ; \mathrm{l} / 4$ lb. $15 \mathrm{c}$; Ib. $40 \mathrm{c}$ 


\section{Squash}

\section{Courge}

Kulchen-Kuerbis

Calabaza

Zucca

The summer varieties come into use early in the summer, but being sensitive to frost the seed cannot be sown until late in April. The seed should be planted in hills four feet apart, using four ounces to 100 hills. The winter varieties are also unable to resist frost, and should be planted at the same time The fruit does not mature until late in the fall, and, having a very firm, hard shell, keeps well, and with a little care squashes can be had all winter and until late in the spring. In gathering winter squashes, it is important to protect the stems, since, if broken off, the fruit will not keep so well. Plant in hills six to eight feet apart, using two or three seeds to the hill. Use eight ounces to 100 hills, or two pounds to an acre. Moderately rich soil will grow good squashes.

\section{SUMIMER VARIETIES}

*EARLY WHITE BUSH SCALLOP. A very early variety, with flat, creamy white, scalloped squashes 4 to 6 inches in diameter. The vine is bush in habit and rather dwarf. This variety is the common patty-pan squash.

Pkt. $5 c$; oz, 10c; 1/4 lb. 25c; Ib. $75 c$

Mammoth Summer Crookneck. A large, golden-yellow variety, thickly warted; is eighteen inches long, brittle, and tender. Plants are bush and very prolific. This is an improved strain of the old variety and considerably larger.

Pkt. $5 c ;$ oz. $10 \mathrm{c} ; 1 / 4$ Ib. 25c; Ib. $80 \mathrm{c}$

Mammoth White Bush Scallop. A fine, large variety with round, scalloped fruit from twelve to fourteen inches in diameter. Color, white, clear and wax-like.

Pkt. $5 c$; oz. $10 \mathrm{c} ; 1 / 4$ Ib. $25 \mathrm{c}$; Ib. $85 \mathrm{c}$

Vegetable Marrow. A large, oblong variety, producing fruit which is dark green at first, becoming marbled and striped with yellow and lighter green as they mature. Pkt. 5c; oz. 10c; 1/4 lb. 30c; lb. $\$ 1.00$

White Summer Crookneck. Long, crooknecked variety, similar to Summer Crookneck in size and shape, but it is pure white. Is of especially fine quality.

Pkt. 5c: oz, 10c; 1/4 lb. 25c; lb. $75 c$

Yellow Bush Scallop, or Custard. An early variety with flat, round, scalloped fruit. Skin, deep yellow; flesh, pale yellow.

Pkt. 5c; oz. 10c; 1/4 lb. 25c; lb. $75 c$

*YELLOW SUMMER CROOKNECK. The well-known summer variety. Fruit long, skin very much warted, and of a bright golden yellow.

Pkt. $5 c$; oz. $10 c$; $1 / 4$ lb. $25 c$; lb. $75 c$

\section{WINTER VARIETIES}

Boston Marrow. A popular variety, with large, oval fruit. Skin bright orange, with light cream netting. Flesh, orange. Fine grained, and of excellent quality.

Pkt. $5 c$; oz. $10 c$; $1 / 4$ lb. 20c; lb. 60c

Delicious. A dark green variety, with thick, orangecolored flesh of the very best quality.

Pkt. $5 c ;$ oz, $15 c ; 1 / 4$ lb. $45 c ;$ Ib. $\$ 1.50$

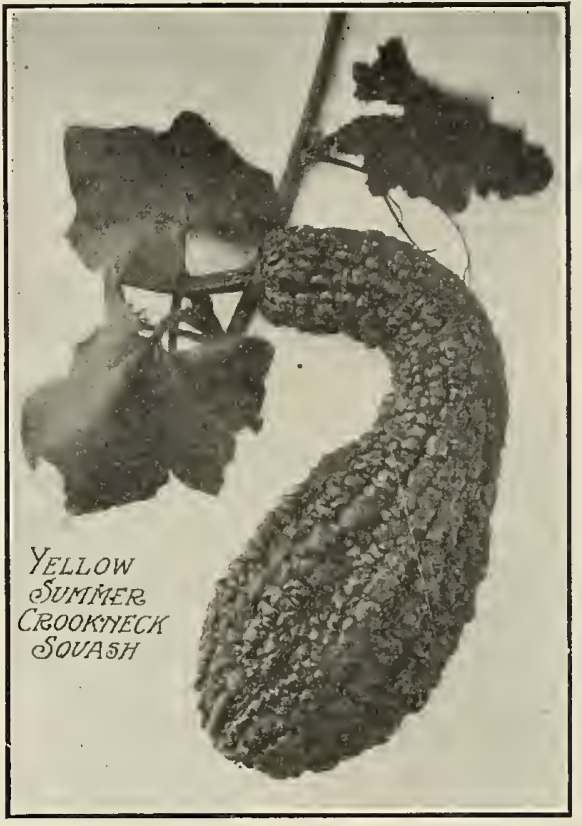

Essex Hybrid, or Hard Shell Turban. An early, quickgrowing variety, with very hard shell. Is broad, with large neck or "Turk's Cap" at blossom end.

Pkt. $5 c$; oz. $10 c ; 1 / 4$ lb. 20 c; lb. $65 c$

Fordhook. A good variety for early winter or even summer use. The fruit is oblong, slightly ridged; is creamy yellow outside and the flesh is thick, and when cooked is of most delicious flavor. Is solid and hard and a splendid keeper.

Pkt. 5c; oz. 10c; 1/4 lb. 25c; lb. 90c

Golden Hubbard. An exceptionally attractive variety of the true Hubbard type. At maturity the color is red, and the flesh bright orange. The vine is pro-

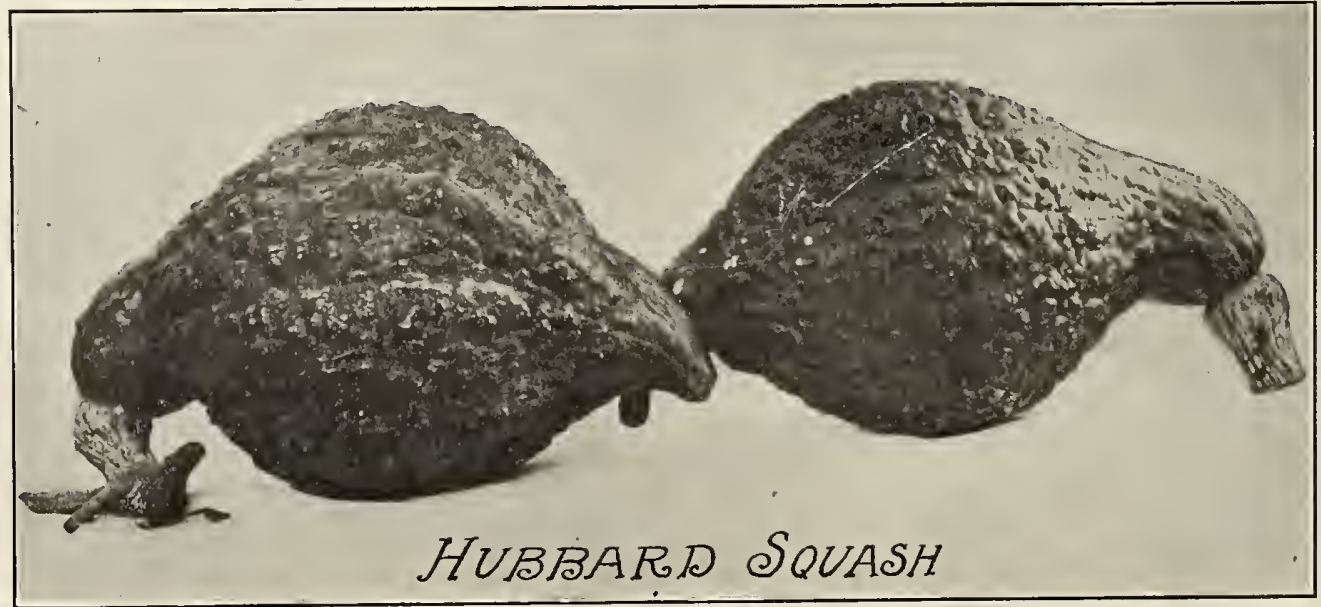


ductive and the fruit is fit for use earlier than the Hubbard. Pkt. 5c; oz. 10c; 1/4 lb. 25c; lb. $75 \mathrm{c}$

*HUBBARD. The most popular and widely used of the winter squashes. Fruit is oblong and pointed, heavily warted, dark green in color, with orangecolored flesh. Is remarkable for its keeping qualities. $\quad$ Pkt. $5 c$; oz. 10c; $1 / 4$ Ib. 25c; Ib. $75 c$

Perfect Gem or Cream. Long-keeping, summer squash, 4 to 6 inches in diameter; apple shaped; distinctly ribbed with smooth, cream-colored skin. It is solid and rather hard, but bakes to a delicious soft consistency on the inside.

Pkt. $5 c$; oz. $10 c ; 1 / 4$ lb. $25 c$; Ib. $75 c$

Mammoth Chili. A .very large variety, with smooth, oblong fruit, flattened at both ends. Skin, rich orange yellow; flesh, orange, fine grained, and sweet.

Pkt. 5 c; oz. $15 c ; 1 / 4$ Ib. 45 c; lb. $\$ 1.50$

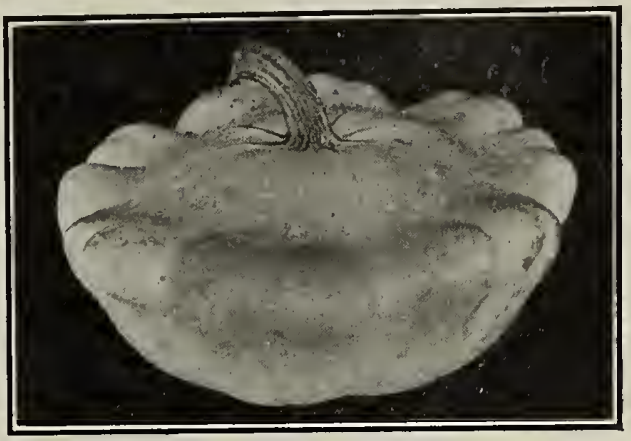

Early "White Bush Scallop"

\section{Tobacco}

Cannot be planted until all danger of frost is over. Tobacco seed should be planted in a seed-bed, and when the plants are about six inches high should be transplanted to rows four or five feet apart, and about four feet apart in the row. About two ounces of seed are sufficient for an acre.

* CONNECTICUT SEED LEAF. The best known and most widely used variety throughout the middle and northern States and Canada. Is the hardiest variety in cultivation. Pkt. $5 \mathrm{c}$; oz. $20 \mathrm{c} ; \mathrm{V} / 4 \mathrm{lb} .60 \mathrm{c} ; \mathrm{Ib} . \$ 2.00$

Havanna (Domestic). An imported variety with very thin leaf and delicate flavor. Especially used for cigar wrappers. Pkt. 10c; oz. 25c; 1/4 lb. 75c; lb. $\$ 2.50$

Vuelta de Abajo (Imported Havanna). The true Havanna tobacco as grown on the island of Cuba.

Pkt. 15c; oz. 50c
White Burley. A popular variety, used extensively for plug tobacco. Pkt. $5 c$; oz. 30 c; $1 / 4$ lb. $\$ 1.00$; lb. $\$ 3.00$

Yellow Pryor. A good general purpose tobacco; makes a fine wrapper, filler, or smoker.

Pkt. 10 c; oz. 25 c; $1 / 4$ Ib. 75 c; Ib. $\$ 2.50$

Kentucky Yellow. A very fine, large, broad-leaved tobacco, suitable for dark wrappers and fillers.

Pkt. $10 \mathrm{c} ;$ oz. $25 \mathrm{c} ; \mathrm{l} / 4$ lb. $75 \mathrm{c} ;$ Ib. $\$ 2.50$

\section{Tomato}

Tomate

Liebesapfel

Tomate

Pomo d'Oro

As tomatoes are very sensitive to frost, they cannot be set in the open field until about May 1st. The seed must be sown in well-protected hotbeds, sowing same about March 1st. A hardy and stocky plant is had by transplanting the small plants in the bed a few weeks before transplanting to the field. Or when about four inches high, the top may be pinched off and the plant grows stockier.

Sow the seed broadcast, using one ounce to about three square feet of area, which will yield plants enough to set an acre. In the field set tall varieties six feet apart and dwarf varieties three feet apart. A slight trellis is advisable in the garden. Good soil produces the best fruit, but it is not necessary that it be excessively rich. Too frequent watering, especially spraying the plant, is injurious to tomatoes in the home garden, but a moderate amount of water should be applied at the roots at regular intervals.

Acme. A tall variety, medium early, bearing flattish, globe fruit of a purplish-carmine color, and medium size. The fruit is smooth and uniform.

Pkt. $5 c$; oz. 25 c; 1/4 Ib. $75 c$; Ib. $\$ 2.25$

Beauty. A rather early, tall variety; very prolific, with good-sized, smooth fruit of a purplish-carmine color.

Pkt. $5 \mathrm{c} ;$ oz. $25 \mathrm{c} ; \mathrm{l} / 4$ Ib. $75 \mathrm{c} ;$ Ib. $\$ 2.25$

*CHALK'S EARLY JEWEL. A wonderful new variety, in that it is early and bears continuously throughout the season. The fruit is large, smooth, uniform, and well ripened clear to the stem, and the flavor and quality are especially fine. Color, bright scarlet.

Pkt. 10c; oz. 25c; V/4 lb. 75 c; Ib. $\$ 2.75$

Crimson Cushion. A tall variety, bearing very large fruit of a bright scarlet color. Fruit rather uneven in size and shape, but is firm and of fine flavor, though rather coarse.

Pkt. $5 c$; oz. 30 c; $1 / 4$ Ib. $\$ 1.00 ;$ lb. $\$ 3.00$

Dwarf Stone. A variety similar in habit to Dwarf Champion. The fruit is larger and of a bright scarlet color. $\quad$ Pkt. $5 c$; oz. 25c; $1 / 4$ Ib. $75 c$; lb. $\$ 2.75$

Dwarf Champion. A dwarf variety, sometimes called the tree tomato on account of its upright growth and its ability to stand alone without trellising. Fruit, medium sized, smooth, uniform, and of a purplish-carmine color.

Pkt. $5 c ;$ oz. 25 c; 1/4 Ib. $75 c ;$ lb. $\$ 2.50$
Earliana (Sparks). The earliest tall variety, forming ripe fruit much earlier than any other variety. The fruit is large, smooth, of a bright scarlet color, and of fine quality. Very valuable for early market use. Pkt. $10 \mathrm{c} ;$ oz. $25 \mathrm{c} ; \mathrm{I} / 4$ Ib. $75 \mathrm{c}$; Ib. $\$ 2.75$

Favorite. A tall variety, bearing globe-shaped, scarlet fruit. The fruit is smooth, and uniform, and well ripened to the stem.

Pkt. 5c; oz. 25c; 1/4 Ib. 75 c; lb. $\$ 2.25$

Golden Queen. A large-fruited, tall variety, bearing smooth, bright yellow fruit of fine quality.

Pkt. $5 c$; oz. 25c; 1/4 lb. $75 c$; lb. $\$ 2.50$

Husk Tomato, or Ground Cherry. A variety that is covered by a loose covering or husk. The true edible variety is yellow and is used for preserves.

Pkt. $5 \mathrm{c} ;$ oz. $25 \mathrm{c} ; \mathrm{1} / 4$ Ib. $75 \mathrm{c} ; \mathrm{Ib} . \$ 3.00$

June Pink. A grand new extra early variety. One of the very earliest sorts we have-a little earlier than Earliana. The fruit is smooth and ripened to the stem and the plant bears well.

Pkt. 10c; oz. $30 \mathrm{c} ; 1 / 4$ Ib. 90c; Ib. $\$ 3.00$

Matchless. A tall-growing, prolific variety with large fruit, which is rather flattened, smooth and uniform. Color, bright scarlet.

Pkt. $5 c$; oz. 25c; I/4 Ib. 75 c; Ib. $\$ 2.50$

Perfection. A tall variety, with medium-sized, globular, uniform fruit, which is smooth and well ripened to the stem. Color, bright scarlet.

Pkt. $5 c$; oz. $25 \mathrm{c} ; \mathrm{I} / 4$ Ib. $75 \mathrm{c} ;$ Ib. $\$ 2.25$ 


\section{TOMATO-Continued}

Ponderosa. An extremely large, irregular-fruited variety. Vine tall, and fruit very solid and purplishcarmine in color. Rather coarse and of fair quality only. Pkt. 10c; oz. 40c; $1 / 4$ lb. $\$ 1.00 ; \mathrm{lb} . \$ 3.50$

Red Cherry. The fruit is small and globe shaped, about 1 to 2 inches in diameter. It is bright scarlet in color, and besides being ornamental, is very valuable for preserving.

Pkt. $5 c ;$ oz. 25 c; 1/4 lb. $75 c$; Ib. $\$ 2.50$

Red Pear shaped. As the name implies, the fruit is shaped like a pear-small at the stem and enlarged at the top. It is small, being about 2 or 3 inches long. It is bright scarlet; is of fine flavor, and makes delicious preserves or salads.

Pkt. $5 c ;$ oz. $25 c ; 1 / 4$ lb. $75 c$; lb. $\$ 2.50$

*STONE. The best main-crop variety for all purposes, and largely used for canning. Vine, tall and prolific. Fruit, smooth, large, and uniform, and well ripened to the stem. Color, bright scarlet.

Pkt. $5 c$; oz. 25 c; 1/4 Ib. 75 c; lb. $\$ 2.25$

Trophy. An old favorite and much esteemed for its productiveness and hardiness. The fruit is some-

what irregular, but of fine quality, and is valuable for canning. The true stock is scarlet in color, and the fruit shows a distinct navel at the blossom end.

Pkt. $5 c$; oz. 20c; 1/4 lb. 60c; lb. $\$ 2.00$

Yellow Cherry. A small-fruited, bright, golden-yellow variety; very attractive for salads or preserves. In all respects like the Red Cherry, except for its golden-yellow color.

Pkt. 5 c; oz. 25 c; 1/4 Ib. 75 c; lb. $\$ 2.50$

Yellow Pear shaped. A small-fruited variety, resembling the Red Pear Shaped, except in color, which is golden yellow. It is very useful for salads when the fruit is simply cut in two lengthwise. It is also useful for preserves.

Pkt. 5c; oz. 25c; 1/4 lb. 75 c; lb. $\$ 2.50$

White's Majestic. A new variety from England and grown by us for the past two seasons. It proves to be a most excellent variety-a prolific bearer and having large, smooth, solid fruit of bright scarlet. It is very meaty, with few seeds, ripens uniformly and well up to the stem. We urge all our customers to try it.

Pkt. 10c; oz. 40c; 1/4 lb. $\$ 1.25$

\section{Turnips}

Navet

Nuben

Nabo

Navosse

While turnips are a favorite fall and winter vegetable, they may also be had in spring by proper sowings They are of easy culture, but need well-worked, rich soil to insure a quick, uninterrupted growth, when they will be tender and free from woodiness.

For fall and winter use sow the seed in August, using one ounce to 250 feet of row, thinning the plants when very young to three or four inches apart. For spring use sow in January.

For field culture sow in rows about two feet apart, using one to three pounds of seed per acre.

Amber, or Yellow Globe. One of the best yellow-fleshed varieties. Skin also clear yellow. Is of large size and fine flavor. Pkt. $5 \mathrm{c}$; oz. $10 \mathrm{c} ; \mathrm{l} / \mathrm{l} \mathrm{lb} .20 \mathrm{c} ; \mathrm{lb} .50 \mathrm{c}$

Cow Horn. A long, pure white variety, resembling a white carrot more than a turnip. The flesh is tender and sweet, and it is quite popular as a market variety on this account.

Pkt. $5 c ;$ oz. $10 c ; 1 / 4$ lb. 20c; Ib. 50c

Early Snowball. A medium globe-shaped variety of pure white. Very solid and of the best quality.

Pkt. $5 c ; 0 z .10 c ; 1 / 4$ lb. $20 c ;$ lb. $60 c$

Extra Early White Milan. A very early variety, medium sized, flat, and clear white. A fine home-garden variety.

Pkt. 5c; oz. 10c; 1/4 Ib. 25c; lb. $75 c$

Extra Early Purple Top Milan. A very early variety, medium sized, very flat, and white with purple top.

Pkt. $5 c ; 0 z .10 c ; 1 / 4$ lb. $25 c ;$ lb. $75 c$

Orange Jelly, or Golden Globe. A globe-shaped, yellow variety with firm and crisp yellow flesh. A very fine table variety. Pkt. $5 \mathrm{c}$; oz. $10 \mathrm{c} ; 1 / 4 \mathrm{lb} .20 \mathrm{c} ; \mathrm{lb} .50 \mathrm{c}$

*PURPLE TOP FLAT DUTCH (Strap Leaf). An early, flat variety. White, with purple top. Probably the most popular and generally used garden variety.

Pkt. 5c; oz. $10 c ; 1 / 4$ lb. 20 c; Ib. $50 c$

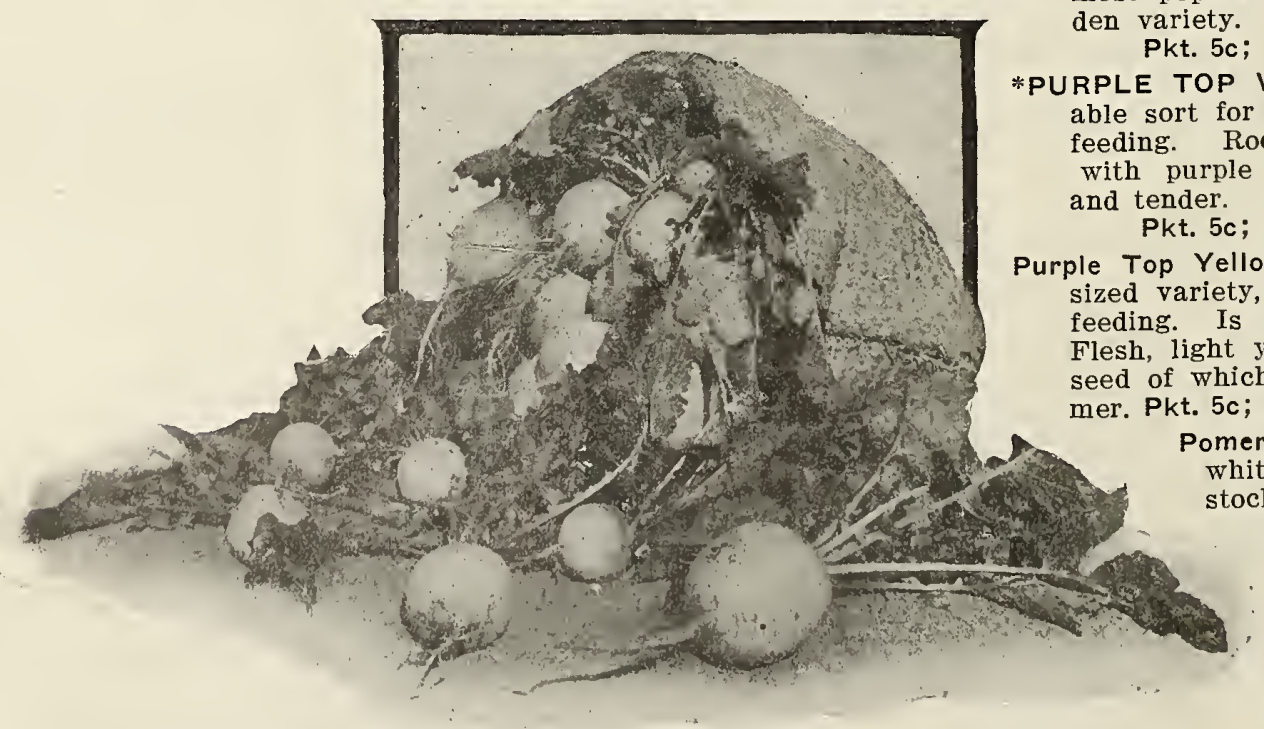
able sort for either table use or stock feeding. Roots, globe-shaped, white, with purple top. Flesh, white, firm, and tender.

Pkt. 5c; oz. $10 c$; 1/4 lb. 20c; lb. 50c Yellow Aberdeen. A medium-

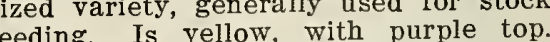
Flesh, light yellow. A winter variety, seed of which should be sown in summer. Pkt. $5 c$; oz. $10 c ; 1 / 4$ lb. 20c; lb. 50c

Pomeranean White Globe. Large white variety, used largely tor stock feeding. Is globe-shaped, large leaves. Hardy. Pkt. $5 c ;$ oz. $10 \mathrm{c} ; 1 / 4 \mathrm{lb}$. $20 \mathrm{c} ; \mathrm{lb} .50 \mathrm{c}$.

Seven Top (for greens). Cultivated for its leaves; cooked same as spinacl and mustard. The root is small and not used.

Purple Top "White Globe" Turnip

Pkt. $5 \mathrm{c}$; oz. $10 \mathrm{c} ; 1 / 4$ lb. $20 \mathrm{c}$; lb. $50 \mathrm{c}$

*EARLY WHITE FLAT DUTCH, STRAP LEAVED. A medium-sized, flat variety; clear white, early, and of fine flavor. A fine table variety.

Pkt. $5 c$; oz. $10 c ; 1 / 4$ lb. 20 c; lb. $50 c$

White Egg. A small, oval-shaped variety with pure, white skin and white, fine-grained flesh. A handsome variety and very early.

Pkt. $5 c ; 0 z .10 c ; 1 / 4$ lb. $20 c ;$ lb. $60 c$ 


\section{Ruta Bagas, or Swedes}

These are grown very extensively for stock feeding, and make an excellent and valuable crop. Treatment same as for winter turnips, but require a longer season to grow, and the seed should be planted early in July. The rows should be at least two and one-half feet apart, and the plants thinned to eight or twelve inches. The roots frequently grow to an enormous size.

*AMERICAN PURPLE TOP, or LONG ISLAND. One of the best and most popular varieties, with yellow flesh. It is yellow below ground, with purple top above, and the leaves are small. A good stockfeeding or table variety.

Pkt. 5c; oz. $10 \mathrm{c} ; 1 / 4$ Ib. $20 \mathrm{c}$; Ib. $50 \mathrm{c}$

Laing's Purple Top. A globe-shaped variety of good quality. Flesh, yellow; skin, yellow below ground and purple above.

Pkt. 5 c; oz. $10 c ; 1 / 4$ Ib. $20 c ;$ Ib. $60 c$

* LARGE WHITE, or SWEET GERMAN. A very large variety, with white skin and white flesh, which is tender and sweet. Pkt. 5c; oz. 10c; I/4 Ib. 20c; Ib. 50c

Monarch, or Tankard. Roots ovoid in shape and very large. Flesh, yellow; skin, yellow below ground and purple above. Pkt. $5 \mathrm{c} ;$ oz. $10 \mathrm{c} ; \mathrm{l} / 4$ Ib. $20 \mathrm{c} ; \mathrm{Ib} .50 \mathrm{c}$

Purple Top YeHow. One of the hardiest and best varieties for all purposes. Skin is bright yellow under ground and purple above ground. Flesh, yellow and of fine flavor. Roots are slightly oblong in shape. $\quad$ Pkt. 5c; oz. 10c; I/4 Ib. 20c; Ib. 50c

Yellow Purple Top Swede. The well-known and most commonly used variety. Roots, globular; skin, yellow under ground and purple above. Flesh of fine flavor. Valuable for either table use or stock feeding. $\quad$ Pkt. $5 \mathrm{c} ;$ oz. $10 \mathrm{c} ; \mathrm{I} / 4 \mathrm{Ib} .20 \mathrm{c} ; \mathrm{Ib} .50 \mathrm{c}$

\section{Aromatic, Medicinal and Pot Herbs}

Anise. A hardy annual. The seed especially being used for seasoning food, also for flavoring liquors and for medicinal purposes. Grows about two feet tall. Sow the seed where the plants are to stand. Pkt. $5 c$; oz. $10 \mathrm{c} ; 1 / 4$ Ib. $30 \mathrm{c} ; \mathrm{Ib} . \$ 1.00$

Balm. A perennial herb used for seasoning, especially in liquors. Has a lemon-like flavor. Thrives in any warm location, and is easy to grow. Plant grows 1 to 2 feet high.

Pkt. $5 c$; oz. $25 c ; 1 / 4$ lb. $75 c$; lb. $\$ 2.50$

Basil, Sweet. A hardy annual, the leaves of which have a clove-like flavor. Used for seasoning soups, meats, and salads. Of the easiest culture; seed can be sown as early as the weather permits.

Pkt. $5 c$; oz. $15 c$; $1 / 4$ Ib. $40 c$; lb. $\$ 1.50$

Borage. The leaves are used for flavoring and the flowers furnish bee pasture.

Pkt. $5 c$; oz. $10 c ; 1 / 4$ lb. $30 c$; Ib. $\$ 1.00$

Caraway. A biennial herb, grown for its seeds, which are used for flavoring breads, cakes and cheese; also occasionally for the young shoots and leaves, which are eaten. Grows two feet high. Is easy of culture. Sow the seed in the spring for seed crop the following year.

Pkt. 5c; oz. 10c; 1/4 Ib. 25c; lb. $75 c$

Catnip. Practically a wild plant. Is a hardy perennial, the leaves of which are used for medicinal purposes.

Pkt. $5 c$; oz. $40 c ; 1 / 4$ lb. $\$ 1.25 ;$ lb. $\$ 4.00$

Coriander. An eaśily grown herb, the seeds of which are used for flavoring pastry, confectionery and liquors. Grows two to three feet high.

Pkt. $5 c ; 1 / 4$ Ib. $15 c ;$ lb. $30 c$

Dill. An annual herb, the seeds of which are used for seasoning. The foliage is also used for flavoring as well as for medicinal purposes. Grows two to three feet high. Its largest use is pickling cucumbers in what is known as "Dill Pickles."

Pkt. 5c; oz. 10c; 1/4 lb. 20c; Ib. 60c

Fennel, sweet. A hardy perennial, the leaves of which are used in soups, garnishes, and salads. The seed should be sown early and plants thinned to six or eight plants to foot of row.

Pkt. $5 c ; 0 z .10 c ; 1 / 4$ lb. $30 c$; lb. $\$ 1.00$

Horehound. 'A hardy perennial shrub, one to three feet high, with whitish, hairy leaves, which are used in confectionery, and in medicines for coughs and colds.

Pkt. 5c; oz. 20c; 1/4 lb. 60c; lb. $\$ 2.00$

Hyssop. A hardy perennial shrub, growing eighteen inches high. Used for medicinal purposes, both green and dried. Pkt. 5c; oz. 20c; 1/4 lb. 60c; lb. $\$ 2.00$

Lavender. A hardy perennial, growing two feet high and forming a bush about four feet in diameter.

Used as a garden plant on account of its fragrant blossoms and foliage. Its long, fragrant stems are frequently used for fancy work when dried.

Pkt. $5 c$; oz. $15 c ; 1 / 4$ Ib. 40 c Ib. $\$ 1.25$

Sweet Marjoram. A half-hardy perennial, the leaves of which are used both green and dried for flavoring or seasoning. Pkt. $5 \mathrm{c}$; oz. $15 \mathrm{c} ; \mathrm{l} / 4 \mathrm{lb} .40 \mathrm{c}$; lb. $\$ 1.25$

Rosemary. A hardy perennial shrub, the leaves of which are used for seasoning and medicinal purposes. Oil of rosemary is distilled from the leaves.

Pkt. $5 c$; oz. 35 c; $1 / 4$ Ib. $\$ 1.00$; Ib. $\$ 3.50$

Rue. A hardy perennial, thriving on poor soil. Has a peculiar smell; leaves are bitter. Is used as a stimulant, but should be used with caution, since its use sometimes results in injury.

Pkt. $5 c$; oz. $15 \mathrm{c} ; 1 / 4$ lb. 40 c; lb. $\$ 1.25$

Sage. A hardy perennial shrub, with whitish-green, oval, and very much wrinkled leaves, which have a pleasant smell and which are used for seasoning. It is easily grown and the seed can be sown almost any time. Its fragrant, purplish flowers are especially attractive to bees, and the finest white honey has its source in sage blossoms.

Pkt. 5 c; oz. 25 c; $1 / 4$ Ib. 40 c; lb. $\$ 1.25$

Summer Savory. A hardy annual, the stems and leaves of which are used for flavoring dressings and soups.

Pkt. $5 c$; oz. $10 \mathrm{c} ; 1 / 4$ lb. $30 \mathrm{c}$; Ib. $\$ 1.00$

Winter Savory. A hardy perennial, the leaves of which are used for seasoning.

Pkt. $5 c$; oz. 20 c; 1/4 Ib. 60 c; Ib. $\$ 2.00$

Tansy. A very easily grown perennial plant, growing about three feet high. Its leaves are used for medicinal purposes, especially for dropsy and kindred disorders.

Pkt. $5 c ;$ oz. 30 c; $1 / 4$ Ib. $\$ 1.00 ;$ Ib. $\$ 3.00$

Tarragon. The leaves are used for seasoning. The plants continue to bear leaves for a long period.

Pkt. 10c

Thyme. A low-growing, half-shrubby perennial, with fragrant leaves, having a mint-like odor, which are used for seasoning.

Pkt. $5 c$; oz. 25 c; 1/4 Ib. 75 c; lb. $\$ 2.50$

Wormwood. A hardy perennial, growing about four feet high. The leaves, which are greatly divided, have a strong, bitter flavor. They are gathered in the summer and dried, and are largely used in medicines for tonics and applications. Also used in liquors, especially absinthe.

Pkt. $5 c ;$ oz. 20 c; $1 / 4$ Ib. 60 c; Ib. $\$ 1.75$ 
We are Headquarters for Grasses for Lawns and for Lawn Mixtures

\section{A Word About Your Lawn}

$\mathrm{T}$

MAKE A GOOD TAWN: The ground should be thoroughly drained and well prepared. The soil ought not to be too rich, as a rapid growth is not wanted in the grasses of a lawn; but the surface should be as much alike in quality as possible. After the ground is prepared, have it thoroughly watered and wait two or three weeks for weeds to start, after which hoe the surface-not too deep, for the soil does not want to be too soft. It would be well to repeat this operation twice if you have time, for you will save a great deal of time in weeding after the lawn is up.

After sowing, the ground should be rolled in order to press the seed firmly into the soil. The proper time to sow grass seed depends, of course, upon the latitude. On this coast it may be sown any time from October to March. The sowing should be done when the ground is moist, or before an expected rain. If the ground can be irrigated, grass seed can be profitably sown during any month of the year.

All turf-forming grasses are improved, both in vigor and root-growth and in fineness of texture, by frequent mowings. It is impossible to say just how often the grass should be mown, as that depends upon the rate at which it grows. Too close cutting should be guarded against, however, especially during the hot summer months, when the roots require some top-growth to protect them from the burning sun. A good top-growth is also necessary to protect the roots from winter frosts.

The custom of sowing Kentucky Blue Grass or Perennial Rye Grass alone has until quite recently been very generally followed in California, but the result in no way compares with the infinitely superior lawns seen in both public and private grounds throughout the Eastern States. We have for some time been experimenting with a view to obtain such a mixture suitable for conditions existing on the Pacific Coast, and have named this formula:

\section{MORSE'S CALIFORNIA LAWN SEED.}

This seed is composed entirely of the choicest recleaned seed, and we can guarante it to contain many times the number of good germinating seeds than can be found in the cheap chaff mixtures so generally offered at low prices. This mixture is absoluteiy the best that experience can suggest or that money can buy, and the lowest price at which it can be sold is:

Lb. $45 \mathrm{c}$, postpaid; or by express or freight, lb. $35 \mathrm{c} ; 100$ Ibs. $\$ 30.00$

\section{OUR GOLDEN GATE PARK LAWN MIXTURE.}

We especially recommend this mixture for those requiring a quick-growing, thick, sturdy lawn which remains green all winter as well as other seasons of the year. This variety contains a small proportion of white clover, just enough to make it a thick mat.

Lb. 45 c, postpaid; or by express or freight, Ib. 35c; 100 Ibs. $\$ 30.00$

\section{MORSE'S VELVET LAWN MIXTURE.}

A combination of soft, deep green grasses, which form a thick mat, especially in the summer. Is easy to cut and easy to grow in good, moist, rich soil. Lb. $45 \mathrm{c}$, postpaid; or by express or freight, Ib. $35 \mathrm{c}$; $100 \mathrm{Ibs}$. $\$ 30.00$

One pound of grass seed is required to seed 250 square feet of lawn. Use half that quantity for renovating old or worn-out lawns.

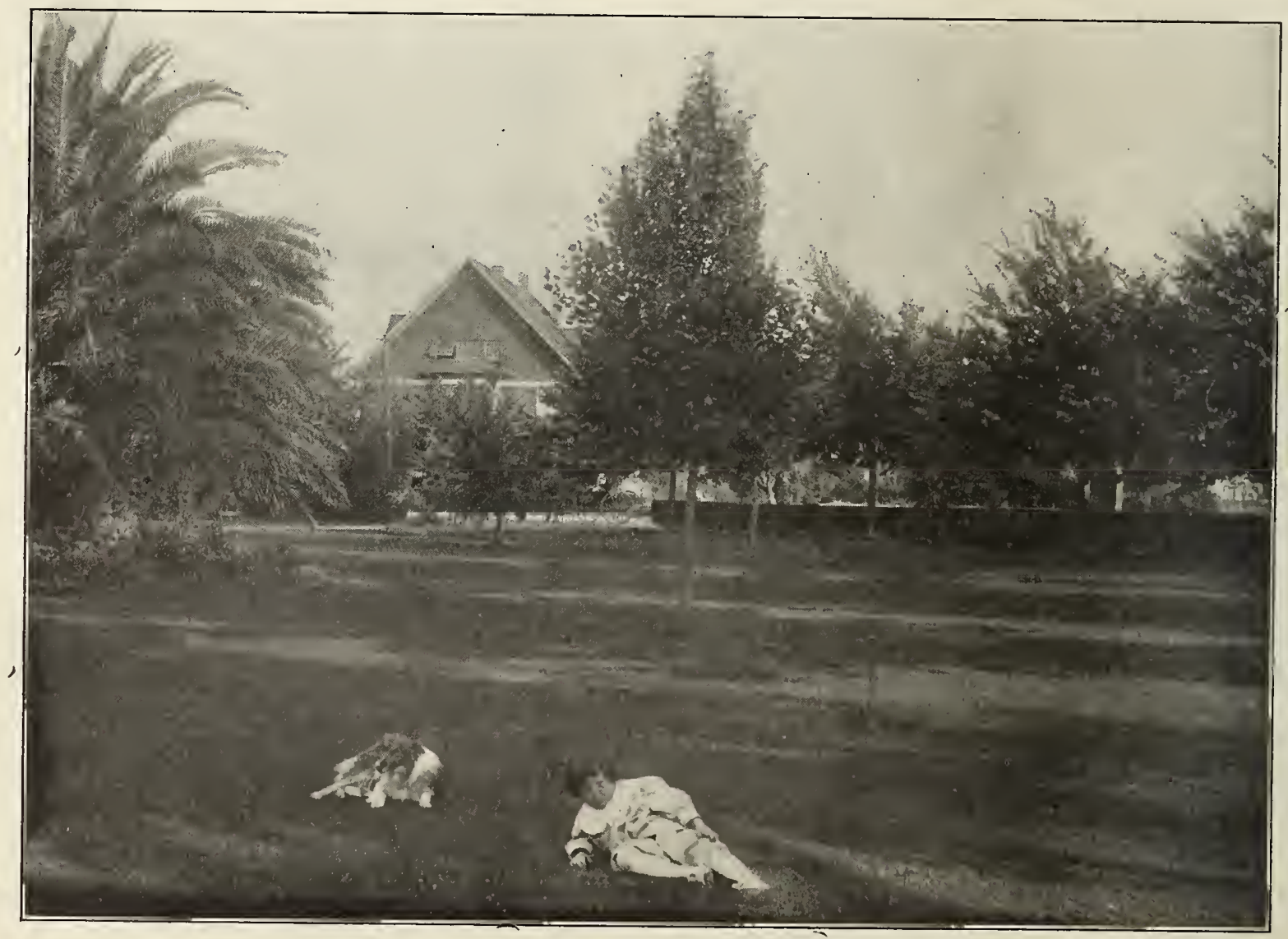




\section{New Crop Grass and Clover Seeds \\ RELIABLE-RECLEANED}

The prices of some varietics of clover seeds may change as the season advances. Prices now given are those prevailing when this entalog was published. It wil be to advantage of intending purchasers to write for samples and special prices before ordering in large qunntities.

If ordered by mail, 10e per pound must be added for postage.

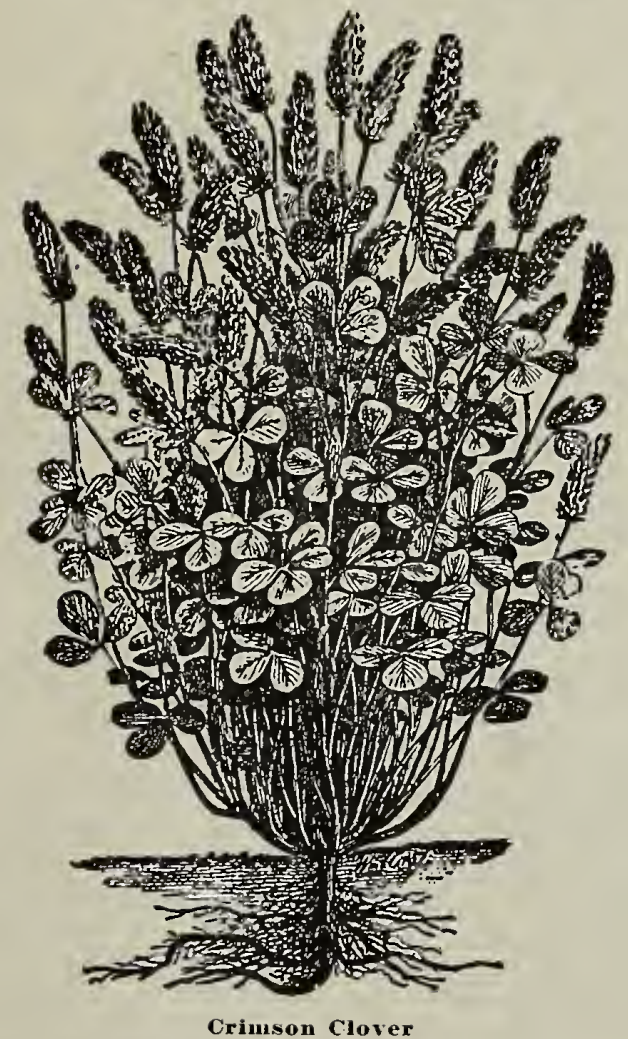

Alfalfa (Medicago Sativa), also known as Lucerne and Chili Clover. One of the most valuable forage or pasture grasses, being very nutritious, both as a a green feed and as hay. It requires very moist land or frequent irrigation, and often bears from five to six crops of hay a year. It does well in almost any climate, and improves any soil that is sown with it. A good stand of it will choke out and practically kill wild morning-glory. Prepare the land by deep plowing and thorough harrowing, and sow 25 to 30 pounds per acre broadcast and harrow in. It is best to sow in the fall after the first rains, but it can also be sown in the spring. The best grade of seed is that grown in Utah, which we offer here. Other grades will be quoted if asked for. Per Ib. 25c; larger quantities at market prices.

Turkestan Alfalfa. This variety comes from Asia Minor and is claimed to be superior to our domestic variety for high lands. Per Ib. 25c; 100 lbs. $\$ 20.00$

Alsike, or Swedish Clover (Trifolium Hybridum). A perennial variety, sometimes preferred to Red Clover, as it is generally finer and makes better hay for horses. The blossoms are also valuable for bees. When used alone, sow 8 to $10 \mathrm{lbs}$. per acre.

Per Ib. 25c; 100 lbs. $\$ 18.00$

Bokhara, or Sweet Clover. Grows 3 to 5 feet high, cov. ered with small, white flowers of great fragrance. Very valuable for bee pasture. Sow 10 pounds to the acre. $\quad$ Per lb. 30c; 100 lbs. $\$ 18.00$

Crimson, or Italian (Trifolium Incarnatum). An annual variety, growing 20 to 30 inches high, and having long, crimson blossoms. Excellent for both pasture and hay. Sow from 12 to 15 pounds per acre, and cut for hay when in full bloom.

Per lb. 25c; 100 lbs. $\$ 20.00$

Burr Clover (Medicago Denticulata). The native forage plant of California. Of the easiest culture, growing all winter and well into summer. We offer only "Hulled seed," which is much easier to sow than in the burr. Sow from August to October, using 15 to 20 pounds of hulled seed per acre. Per Ib. $15 \mathrm{c} ; 100$ lbs. $\$ 10.00$.

Japan Clover. Thrives in any soil and in the dryest seasons; it makes fair hay and stock eat it readily when green. Sow in the spring, $15 \mathrm{lbs}$. per acre.

Per lb. $35 \mathrm{c} ; 100$ lbs. $\$ 30.00$

Mammoth Red or Sapling (Trifolium pratense). Similar to Red Clover, but coarser, taller, and more hardy. Sow from 12 to 15 pounds per acre.

Per Ib. 25c, postpaid; 100 lbs. $\$ 20.00$

Red Clover (Trifolium pratense). Standard clover for all purposes. It yields the heaviest crop of any variety except alfalfa, and makes superior hay, especially if mixed with Timothy. Sow from 12 to 15 pounds per acre. Per Ib. $25 \mathrm{c} ; 100$ lbs. $\$ 20.00$

White Dutch (Trifolium Repens). Spreading, vine-like variety, with white blossoms; used largely for bee pasture. Is also an excellent pasture plant for either sheep or cattle; also makes a beautiful lawn. Per lb. 25c; 100 lbs. $\$ 22.00$; extra fine quality for lawns, $30 \mathrm{c}$ per Ib.; 100 lbs. $\$ 25.00$.

\section{Grasses}

Awnless Brome Grass (Bromus Inermis)-Will stand droughts and produce

Weight Quantity
per bush. per Acre. Per Ib. 100 lbs. heavy crops in dry sections and on poor soils where other grasses perish. It is one of the hardiest grasses and succeeds in a wide range of tem.

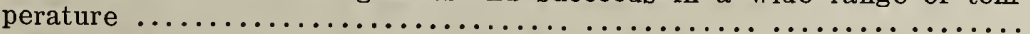

Bermuda Grass (Cynodon Dactylon)-Of great value in the southern part of

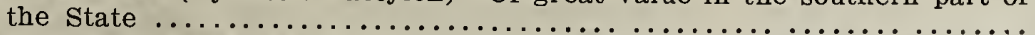

Creeping Bent Grass (Agrostis Stolonifera) - Excellent for lawns; succeeds

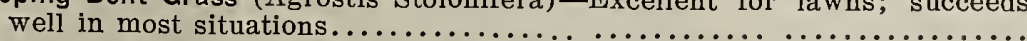

Crested Dog's Tail (Cynosurus Cristatus) - Should enter in moderate quan-

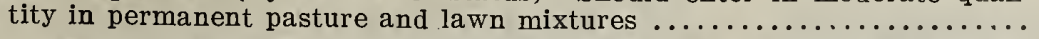

Hard Fescue (Festuca Duriuscula)-A dwarf-growing grass, forming a dense, fibrous mat, succeeding well in dry situations

40 lbs. $\$ 0 \quad 20 \quad \$ 1500$

35 lbs. $\quad 10$ lbs. $\quad 60 \quad 5000$

20 lbs. $\quad 40$ lbs. $\quad 35 \quad 2800$

$21 \mathrm{lbs} . \quad 30 \mathrm{lbs} . \quad 65 \quad 6000$

$16 \mathrm{lbs} . \quad 30 \mathrm{lbs} . \quad 25 \quad 2000$


GRASSES-Continued

Hungarian Grass (Panicum Germanicum) - Is a valuable annual forage plant Italian Rye Grass (Lolium Italicum) - Thrives in almost any soil and yields early and abundant crops. Sown in the fall, will produce an excellent hay crop the following season, but lasts only one year.............

Kentucky Blue Grass (Poa Pratensis) -Fancy or double extra clean. Though offered at the standard weight of $14 \mathrm{lbs}$. per bushel, the natural weight

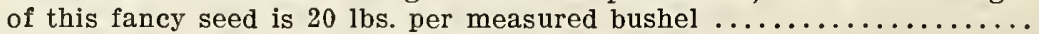

Meadow Fescue, or English Blue Grass (Festuca Pratensis)-Of great value

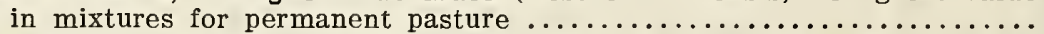

Meadow Foxtail (Alopecurus Pratensis)-One of the best grasses for permanent pasture, early and of rapid growth $\ldots \ldots \ldots \ldots \ldots \ldots \ldots \ldots \ldots$.

Mesquite (Holcus lanatus) - Valuable on the cleared redwood and pine lands of California and Oregon, giving large crops of hay and good pasture.....

Millet German (Panicum Germanicum; Var.) - Will grow on any good land and yields heavily when artificially watered; yields from 40 to 60 bushels of seed per acre, which is excellent food for stock or poultry.........

Pearl Millet (Pencillaria)-A perennial plant for fodder. Grows tall and yields an enormous amount of corn-like leaves. Sow in drills or broad-

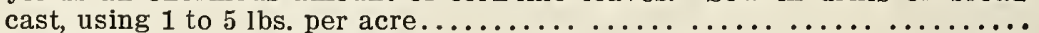

Orchard Grass (Dactylis Glomerata)-One of the most valuable of all pasture grasses; produces an immense quantity. of forage, and well adapted for

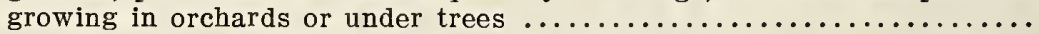

Perennial Rye Grass (Lolium Perenne)-It grows rapidly and makes a good

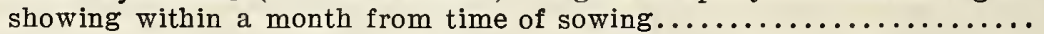

Australian Rye Grass-Specially selected and recleaned, for lawns........

Red Fescue (Festuca Rubra) - Forms a close, rich sod and is valuable in

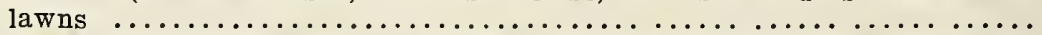

Red Top (Agrostis Vulgaris) - Valuable either for hay or permanent pasture; reaches highest perfection on moist, rich soils. In chaff............

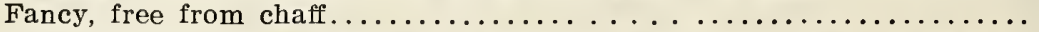

Rhode Island Bent Grass (Agrostis Canina)-A very fine variety for lawns..

Rough-Stalk Meadow Grass (Poa Trivialis)-Excellent for pastures and mea-

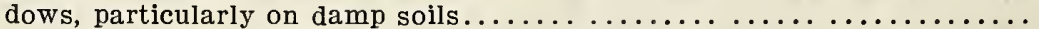

Sheep's Fescue (Festuca Ovina)-Short and dense in growth, excellent for

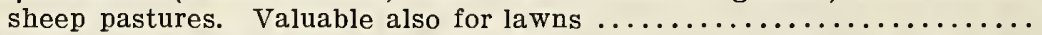

Sweet Vernal, True Perennial (Anthoxanthum Odoratum)-Emits an agree-

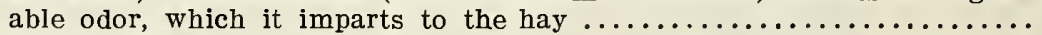

Tall Meadow Fescue (Festuca Elatior)-Early, nutritive and productive in

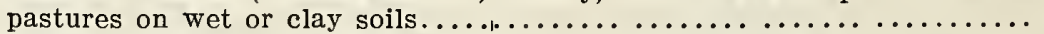

Tall Meadow Oat Grass (Avena Elatior) - Of rapid, luxuriant growth, recom-

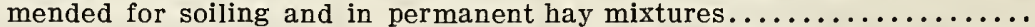

Timothy (Phleum Pratense)-The grade we offer is particularly "choice," free from weed seeds and of high germinating power................

Wood Meadow Grass (Poa Nemoralis) - Of early growth and thriving well

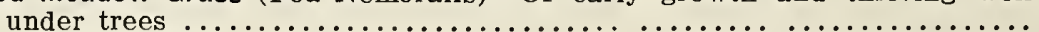

Weight
per bush.

48 lbs.

$20 \mathrm{lbs}$

14 lbs.

27 Ibs.

$7 \mathrm{Ibs}$

7 lbs

$48 \mathrm{lbs}$

Quantity

60 Ibs.

Per 1

Per

s. \$0 $10 \quad 600$

50 lbs.

10

800

$60 \mathrm{lbs}$.

30

2500

35 lbs.

15

1200

4 lbs.

35

In mixtures.

35 lbs.

10

$30 \quad 00$

(

30 lbs.

10

500

5 Ibs.

15

1200

$14 \mathrm{lbs}$

25 lbs.

25

1800

$24 \mathrm{lbs}$.

$50 \mathrm{lbs}$

15

900

......

......

15

1000

14 Ibs.

30 lbs.

25

2200

14 lbs.

30 lbs.

25 lbs.

$50 \mathrm{lbs}$.

$2 \mathrm{lbs}$.

$15 \mathrm{lbs}$.

14 lbs.

20 lbs.

1800

2800

$16 \mathrm{lbs}$.

35 Ibs.

45

4000

$10 \mathrm{lbs}$.

$3 \mathrm{lbs}$ In mixtures.

25

2000

20 lbs.

40 lbs.

75

45

$40 \quad 00$

12 lbs.

40 lbs.

25

2000

45 lbs.

15 lbs.

10

900

19 lbs.

30 lbs.

60

5500

\section{Field Seeds}

Australian Salt Bush (Atriplex semi-bacata). A valuable plant for poor soils, especially those containing alkali. Sow seed in the fall to get the benefit of early rains, using 1 to 2 pounds per acre. After the plant gets a good start, it will grow with very little moisture. Oz. $10 c ; 1 / 4$ lb. 30c; Ib. $\$ 1.25$, all postpaid.

Broom Corn (Improved Evergreen). Used for making brooms, and extensively used on account of its green color and long brush. It grows about 7 feet high.

Per Ib. $15 \mathrm{c}$, postpaid; 100 lbs. $\$ 8.00$

Buckwheat (Japanese). The best and most profitable variety. It is earlier than Silver Hulled, and usually more productive. Is also excellent for bee pasture.

Per Ib. 20c, postpaid; 100 Ibs. $\$ 5.00$

Buckwheat (Silver Hulled). A very good and popular variety. Grain is of a light color, rounder than the common variety; has a much thinner husk, earlier, and yields more. Per lb. 15c, postpaid; $100 \mathrm{Ibs} . \$ 5.00$
Canary. The seed is used for bird food. Is valuable also as an ornamental grass and has considerable merit as hay for feeding cattle.

Per lb. 20c, postpaid; 100 lbs. $\$ 8.00$

Canada Field Peas. Used principally for green manure. Is a strong, vigorous grower, making long vines and good roots. Sow broadcast, using 80 to 100 pounds of seed per acre.

Per lb. 20c, postpaid; 100 lbs. $\$ 5.00$. Larger quantities on application.

Peas, Niles. A local variety, answering the same purpose as the above. Write for quotations.

Cow Peas (Black Eye). Used largely for green manure. It is also valuable if allowed to mature the seed, when the dry vines can be plowed under and the seed used to grind as feed for stock. If for green manure, sow broadcast, using 80 pounds per acre. If for seed or fodder, sow in rows 3 feet apart, using 40 pounds per acre.

Per Ib. 20c, postpaid; 100 lbs. $\$ 7.00$ 
Flax Seed. Should be sown in the spring on moist land, using 30 pounds of seed per acre if grown for a seed crop, or twice that quantity if intended for a crop of fiber.

Per Ib. 20c, postpaid; 100 lbs. $\$ 4.50$

Hairy Vetch (Vicia Villosa). A pea-like plant growing about 4 feet high and doing well on dry, sandy soils for forage. Also a valuable green manure plant for sowing in the fall. Sow broadcast, 60 to 100 pounds per acre.

Per Ib. 20c; 100 Ibs. $\$ 12.00$

Hemp (Kentucky Hemp). A staple crop for manufacturing, sown broadcast, using 25 pounds of seed per acre. For a seed crop, should be sown in hills 4 feet apart. Grows 12 to 14 feet high, with deep cut, dark green leaves, which are rather fragrant. Makes a stately row along a walk, and is an interesting garden annual. The seed is used in birdseed mixtures. $\quad$ Per Ib. $25 \mathrm{c}$, postpaid; $100 \mathrm{lbs}$. $\$ 7.50$

Jersey or Cow Kale. A tall-growing variety having a large bunch of cabbage-like leaves on the top of a stout stem. $\quad$ Pkt. $5 \mathrm{c} ; 0 \mathrm{z} .10 \mathrm{c} ; \mathrm{1} / 4 \mathrm{lb} .20 \mathrm{c} ; \mathrm{Ib} .60 \mathrm{c}$

Jerusalem Corn, or Dhoura. Belongs to non-saccharine sorghums. It is considered a good grain for dry sections and seasons. It produces several small heads on side shoots, often as many as 8 heads on a stalk. The seed is small and makes excellent chicken food. Plant $3 \mathrm{lbs}$. per acre.

Per Ib. 20c, postpaid; 100 lbs. $\$ 6.00$

Kaffir Corn. Grows from 6 to 10 feet high and thrives in hot, dry climates. Makes good fodder for cattle, and the seed is used for stock and chicken food. Sow in rows 3 feet apart, using 5 pounds per acre.

Per lb. 20c, postpaid; 100 lbs. $\$ 6.00$

Paspalum Dilitatum. A new grass for hot; dry climates. A hardy perennial from Australia, growing 5 feet high, without getting tough, and seems to be particularly adapted for grazing dairy cattle. It stands drought remarkably well, and shoots rapidly again with the first shower of rain, and is a splendid winter grass. Although it will stand a considerable degree of frost and even snow without harm, still it requires hot summer weather to grow it to perfection. The seed requires about 3 weeks of moist, genial weather to germinate it, but once established, it seems to stand anything. Per oz. 10c; lb. 75c

Rape (Dwarf Essex). A biennial crop, used principally for sheep pasture. Is usually sown broadcast on ranges, using 2 to 5 pounds per acre.

Per lb. 25c, postpaid; 100 lbs. $\$ 8.00$

Soja Bean. Valuable as a forage crop or green manure. Also as a green fodder and silo plant. Sow 30 pounds per acre.

Per Ib. 25c, postpaid; 100 lbs. $\$ 15.00$

Spring Vetches, or Tares (Vicia Sativa). A plant resembling pea vines, and valuable for forage or green manure. It is usually sown with oats or wheat to hold them up. Sow 60 pounds per acre with grain, or 80 to 100 pounds if sown alone.

Per lb. 20c, postpaid. Larger quantities on application.

\section{Horticultural Tools and Requisites}

BELLOWS AND SPRAYERS.

Adapted for distributing poison, powders and liquids for the destruction of insects in gardens, greenhouses, orchards, poultry yards, etc.

The Houchin Powder Bellows. Jumbo Powder Gun.

Price, $75 \mathrm{c}$ each

RUBBER PLANT SPRINKLERS.

(Postage extra. 10c each.)

Straightneck, $\$ 1.00 ;$ Angleneck, $\$ 1.00$.
Sugar Cane (Sorghum), Early Amber. A good fodder if cut when 2 feet high. Is nutritious and yields a heavy crop. Sow late in April, using 10 pounds seed per acre in drills, or 25 pounds broadcast.

Per Ib. 20c, postpaid; 100 Ibs. $\$ 4.00$

Early Orange. A strong, productive variety, either for fodder or for syrup.

Per Ib. 25c, postpaid; 100 lbs. $\$ 7.50$

Sunflower (Large Russian). A variety bearing large heads, frequently 12 to 20 inches in diameter and sometimes yielding 1,000 pounds of seed per acre. The seed is used for feeding chickens and parrots. Sow in the open field as soon as danger from frost is over, using 3 pounds of seed per acre, sowing in rows 5 feet apart and thinning to 1 foot.

Per lb. 20c, postpaid; 10 lbs. 70 c; 100 lbs. $\$ 6.00$

Speltz, or Emmer. A valuable grain from Russia. Grown in the United States for several years. It is adapted to a wide range of soil and climate, and is of superior feeding value, yielding much more heavily than oats and barley. This grain grows tall, like rye, and matures as early as barley, and yields from 40 to 80 bushels to the acre, and from 4 to 6 tons of straw hay. Tough and hardy, it stands the drought better than any other grain, making it a sure crop. Prepare your land as you would for wheat or oats, and sow at the rate of 75 or 100 pounds per acre. Sow very early in the spring or fall and do not let it stand until it gets too ripe before cutting, as any grain that yields well shells easily. In the green state it makes an excellent pasture. Per lb. 15c, postpaid; express or freight, 100 lbs. $\$ 4.00$.

Teosinte (Reana Luxurians). This plant grows quickly and produces a large quantity of forage in warm locations. It makes splendid dry fodder, yielding enormously, and being more nutritious and better relished by all stock than corn fodder. The seed should not be sown until all danger of frost is past. If cut for green forage, which can be done at any stage during growth, two or more joints should be left at the base of the stalk. These will sprout out quickly into fresh growth, making an even larger crop than at first cutting. Sow in drills 4 feet apart, using 4 pounds of seed to an acre. Oz. 10c; lb. $75 \mathrm{c}$

Velvet Bean. Used largely as a green-manure plant and also for forage. Grows taller and larger than any other soil plant, being sometimes 30 feet in length. Sow same as cow peas, in rows 5 feet apart and in hills 4 feet apart in the row.

Per lb. 25c, postpaid; 100 lbs. $\$ 10.00$

Whipporwill Peas. This variety is a great favorite in the West and South as a green manure and fodder pea. Is early and grows close to the ground.

Per Ib. 20c postpaid; 100 Ibs. $\$ 7.00$

Wild Rice (Zizania Aquatica). A native plant, growing in shallow water with mud bottom. The seed is difficult to germinate, and should be kept moist several days before sowing. The plant makes an excellent shelter for wild fowl, and is much esteemed on game preserves. Per lb. 30c, postpaid. Larger quantities on application.

Bellows, Double Cone................. Each $\$ 3.50$

Bellows, Large Single Cone, with spreader... “ 1.25

Bellows, Smali Single Cone............. “ 1.25

Liquid Atomizer, large................ “ " 2.50

Liquid Atomizer, small................ “ 1.50 


\section{HORTICULTURAL TOOLS AND REQUISITES-Continued}

THE "COOPER" BRASS HOSE MENDER. Made of thin brass tubing; will not rust or wear out; scarcely decreases the flow of water. Easily applied by any one; simply cut out your bad piece of hose and force the ends of the good hose over the mender until they meet in the center. No other fastening is required; the barbs will hold it firm, and no matter what strain is put on the hose it will be as good as new at the point mended, and it will not leak.

Price, 10c each; $\$ 1.00$ per dozen. Postage, $15 \mathrm{c}$ per dozen.

WATERING POT. Galvanized iron, with brass fittings and two brass roses, one fine and one coarse, with each pot. f-quart, $\$ 2.50 ; 8$-quart, $\$ 2.75 ; 10$-quart, $\$ 3.25$.

GRAFTING WAX, $1 / 4$ Ib. $10 \mathrm{c} ; 1 / 2$ lb. $15 \mathrm{c} ; \mathrm{lb} .25 \mathrm{c}$.

GARDEN STAKES. Heavy, round, painted green, pointed.

5 feet, $\$ 1.35$ per doz.; 4 feet, $\$ 1.25$ per doz; 3 feet, 90 c per doz.

\section{GOPHER AND MOLE TRAPS,}

Macabee Gopher Trap. Without doubt the best trap made; never fails to catch them.

$30 \mathrm{c}$ each

Mole Trap. Best English make.

35 c each

KNIVES, BUDDING. Ivory handles, finest quality English steel, straight blade, long handle, $\$ 1.50$. Round point blade, curved handle, \$1.25. Special knife for propagating, round blade, ebony handle, ivory wedge, $\$ 1.25$.
KNIVES, PRUNING. Ebony handles, finest quality. Medium size, single blade, $\$ 1.00$; large size, single blade, $\$ 1.25$.

LABELS, WOODEN. For trees, pots, and gardens.

\section{Tree Labels}

\section{Per 100. Per 1000} Unpainted.

$31 / 2$-inch iron wire........\$0.20

$31 / 2$-inch copper wire........ .30

4 -inch Pot Labels.......... .15

5 -inch Pot Labels......... . .20

6 -inch Pot Labels.......... .20

8 -inch Pot Labels............. 50

10 -inch Garden Labels....... .60

$\begin{array}{rr}\$ 1.25 & \text { Painted. } \\ 1.75 & 2.50 \\ .75 & 1.00 \\ 1.00 & 1.35 \\ 1.20 & 1.65 \\ 4.00 & 4.50 \\ 6.25 & 7.00 \\ 100 & \text { lbs. } \$ 4.00\end{array}$

SYRINGES, SOLID BRASS.

The Morse Garden Syringe. Polished brass, $18 \times 1 \frac{1}{2}$ inches, fitted with adjustable plunger; one coarse rose, one fine rose, and one jet spray. \$5.00 each

Ladies' Garden Syringe. Polished brass, $16 \times 11 / 4$ inches, coarse and fine spray and jet.

$\$ 4.00$ each

RAFFIA. Largely used by nurserymen and others and considered the best and cheapest material for tying known. Is not affected by moisture or change of temperature, so that cutting or injuring the most delicate branches need not be feared, and does not break or ravel when folded or knotted.

Per Ib. 20c; in 10-Ibs. lots, $15 \mathrm{c}$ per lb.

TROWELS. Solid shank, cast steel.

$50 \mathrm{c}$ each

\section{Planet Jr. Tools}

THE BEST GARDEN IMPLEMENTS ON THE MARKET

We offer the following, which can be recommended for all who desire good tools:

\section{Packed} Weight.

No. 4.

No. 4.

No. 25.

No. 6.

No. 6.

No. 36 .

No. 3.

Hill and Drill seeder and Single

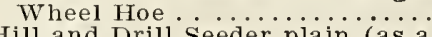

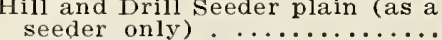
$38 \mathrm{lbs}$. Hill and Hill and Drill Seeder and single Wheel Hoe ................ $58 \mathrm{lbs}$

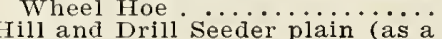
seeder only) ............. $50 \mathrm{lbs}$

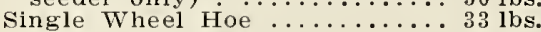
Hill and Drill Seeder ........... 46 1bs.
Price. $\$ 1150$

$\begin{array}{rr}9 & 50 \\ 14 & 00\end{array}$

1400

1150

$\begin{array}{rr}11 & 50\end{array}$

1100

\section{Insect Destroyers}

When ordered by mail-Powders and soaps quoted by the pound can be sent by mail if 150 per pound is added to the priees to pay postage. Fluids and powders in original packages of more than four pounds weiglt are not mailable and can only be sent by express.

Bordeaux Mixture. The best and most generally used spray for blight, mildew, etc. All prepared and ready for use; makes 50 gallons.

1-quart cans, $65 \mathrm{c} ; 1$-gallon cans, $\$ 1.50$

Grape Dust. A non-poisonous powder for the remedy and control of mildew and rot on grapes, roses, etc.

5-Ib. package, $50 \mathrm{c}$

"Rose-Leaf" Extract of Tobacco. Most effectual for the destruction of insects on plants. Dilute with from 30 to 150 parts of water.

1 pint, $55 \mathrm{c} ; 1$ quart, $75 \mathrm{c} ; 1$ gallon, $\$ 2.50$

Slug-Shot. Destroys all insects injurious to house and garden plants, vegetables, and fruits of all kinds, also poultry lice; as effective as Paris green without the danger from poison. 1-lb. cartons with perforated top for applying, 20c each; if by mail, 20c extra; 5-Ib. package, 40c; 10-lb. package, 75c. Tin Dusters for applying Slug-Shot, $40 \mathrm{c}$ each.

Tobacco Dust. The most economical form to use tobacco as an insecticide; fatal to green and black fly and similar garden pests, by simply dusting over the plants.
Kerosene Emulsion. Ready to use; will kill San Jose scale and other tree pests; malies 25 gallons of spray. 1-quart cans, $65 \mathrm{c} ; 1$-gallon cans, $\$ 1.50$

California Wash. Lime, sulphur, and salt. The excellent spray for scale, etc.; makes 30 to 40 gallons of spray. 1 -quart cans, $65 \mathrm{c} ; 1$-gallon cans, $\$ 1.50$

Paris Green, in cans; pure. $\quad 1 / 2 \mathrm{lb} .30 \mathrm{c} ; 1 \mathrm{lb} .50 \mathrm{c}$

Powdered Hellebore. For killing caterpillars and other pests of this nature. Is a poison and very deadly to insects but not to people.

I/2-lb. package, 20c; 1-Ib. package, $35 \mathrm{c}$.

Sulpho-Tobacco Soap. A wonderful insect and bug exterminator. Gives best results in quiclily exterminating all insect life on plants and flowers, in and out of doors. For domestic purposes it rids the house of cockroaches, and is a superior wash for dogs and all animals. A trial will give highly gratifying results. $3-0 z$. cake (makes $11 / 2$ gallons prepared solution), 10c; mailed postpaid, 13c;8-oz. cake (makes 4 gals. prepared solution), 20c; mailed postpaid, $28 \mathrm{c}$.

Whale Oil Soap. Dissolved in water makes an excellent spray for scale on palms, etc $1 / 2-1 b$. package, $15 c ; 1-1 b$. package, $25 c$ 


\section{California Tree and Shrub Seeds}

The vitality of tree and shrub seeds cannot be tested before the sale, but only such seeds are sent out as we believe will give complete satisfaction. No guarantee of genuineness or germination can be given, and we presume that parties ordering have read the above and agree to the conditions.

Price per Packet, 10 cents, except where noted.

Abies Douglasii (Douglas Spruce). A very large and important timber tree 200 to 300 feet high; of pyramid shape. Found throughout the Rocky Mountains, from Oregon to Mexico. Very hardy.

Per oz. 30 c; Ib. $\$ 3.00$

Cupressus Goveniana (Goven's Cypress). 30 to 40 feet high; very ornamental; found in the Coast Ranges of Monterey.

Per oz. $40 \mathrm{c}$; Ib. $\$ 4.00$

"Lawsoniana (Lawson's Cypress). A handsome tree, with white fragrant wood, free from knots; easily worked and very durable. Per oz. 40c; lb. $\$ 4.00$

“ Macrocarpa (Monterey Cypress). A tree 40 to 60 feet high, rough bark; spreading, horizontal branches, rich green foliage; very ornamental for lawns or parks; also used extensively for hedges.

Per oz. $15 \mathrm{c}$; Ib. $\$ 1.00$

Libocedrus Decurrens (Thuya Craigiana). A fine, hardy timber tree; known as White Cedar of California.

Per oz. 40 c; Ib. $\$ 4.00$

Madrone. A beautiful native tree of California. The foliage is a deep green and leathery; it attains a considerable size; flowers white.

Pkt. 25c

Manzanita. A low-growing tree or shrub, bearing attractive white blossoms and beautiful red berries.

Pkt. 25c

Picea Grandis (Western Balsam Fir). Grows 200 to 300 feet high, 4 to 6 feet in diameter; grows rapidly in rich, moist soil; valuable timber tree.

Per oz. 40 c; Ib. $\$ 4.00$
Picea Magnifica. The Red Fir of the Sierras, found at an altitude of 7000 feet; very hardy.

Per oz. 50c; lb. $\$ 5.00$

Date Palm (Phoenix Canariensis). A beautiful- longleaved variety growing to an immense height.

1000 seeds for $\$ 1.50$

Pinus Insignis (Monterey Pine). A very ornamental tree for parks and lawns; grows from 60 to 70 feet high; of rapid growth; has beautiful green foliage.

Per oz, 30c; lb. $\$ 3.00$

"Jeffreyi. A magnificent tree, usually found at an elevation of 5000 feet; very hardy.

Per oz. $35 c$; Ib. $\$ 3.50$

"Lambertiana (Sugar Pine). A hardy tree of gigantic dimensions; found on both slopes of the Sierras. The finest pine timber tree. Per oz. 30c; lb. $\$ 3.00$

"Ponderosa (Yellow Pine). One of the largest pines known. Found in Coast Range on the highest points. Very hardy. The most valuable timber variety.

Per oz. 30c; lb. $\$ 3.00$

"Sabiniana (Nut Pine). Abundant over the dry and hot hills of the Coast Range. Very hardy.

Per oz. 20c; Ib. $\$ 2.00$

Sequoia Gigantea (Wellingtonia Gigantea). The mammoth tree of California. This is the largest tree known to exist on the American continent.

Per oz. 70c; Ib. $\$ 7.00$

" Sempervirens. Usually known as California Redwood. The most valuable timber of the California forests.

Per. oz. 40 c; Ib. $\$ 4.00$

Wild Cherry. A native California hedge plant resembling holly.

\section{Australian Tree and Shrub Seeds}

SUITABLE FOR CULTURE ON THE PACIFIC COAST

Price per Packet, 10 cents, except where noted.

Acacia Baileyana. A handsome tree, with glaucous foliage; in great demand for street planting. One of the most beautiful of the Acacias.

Per oz. 40 c; Ib. $\$ 4.00$

"Decurrens (The Black Wattle of Australia). In California it has gnown over 50 feet in eight years.

Per oz. $40 \mathrm{c}$; Ib. $\$ 4.00$

“ Melanoxylon. In irrigated glens of deep soil this tree will attain the height of 80 feet with $\dot{a}$ stem several feet in diameter.

Per oz. 40 c; Ib. $\$ 4.00$

Mollissima. A fine, erect, rapid-growing tree, with glaucous green, feathery foliage; flowers yellow, and borne in racemes.

Per oz. $40 \mathrm{c}$; Ib. $\$ 4.00$

Eucalyptus Amygdalina (Giant Gum Tree). Is one of the best for subduing malarial effluvia in fever regions, although it does not grow with quite the same ease as the Eucalyptus globulus.

Pkt. 25 c; oz. $75 c$; lb. $\$ 7.50$

"Citriodora. The well-known lemon-scented gum; a popular favorite.

Pkt. $50 \mathrm{c}$; oz. $\$ 2.00$

Ficifolia. Very ornamental for lawn or avenue planting; has beautiful crimson flowers.

50 c per packet of 25 seeds

Globulus (Blue Gum). A very rapid-growing tree, making valuable timber. The common varietythe one most generally planted. Per oz. 50c; Ib. $\$ 5.00$

Leucoxylon (Ironbark Tree). The culture of this variety is desirable on poor, stony land, where other Eucalypti would be unsatisfactory.

Pkt. 15c; oz. $\$ 1.00$

"Marginata (Jarrah of Western Australia). A very excellent timber. Resists teredo, on which account it is largely used for piles.

Per oz. $75 c$

Eucalyptus Robusta (Swamp Mahogany). Thrives best on low grounds, especially near the sea coast.

Pkt. 25c; oz. $\$ 1.00$

"Rostrata (Red Gum), A rapid-growing tree; stands heat and considerable cold without injury. Imported, oz. $75 \mathrm{c}$; Ib. $\$ 7.50$. Domestic, oz. $50 \mathrm{c}$; Ib. $\$ 4.00$.

Stuartiana (Apple-Scented Gum Tree). Seems to do equally well on rather dry and sandy as on humid soils. The wood is of a handsome dark color and takes a good polish.

Pkt. $15 \mathrm{c} ;$ oz. $\$ 1.00$ Viminalis. In poor soil it grows to a moderate height; in rich soil it attains gigantic dimensions.

Per oz, $75 \mathrm{c} ; \mathrm{lb}, \$ 7.50$

We import seed of the following desirable varieties of Eucalypti, and offer at the uniform price of $15 \mathrm{c}$ per packet, $75 \mathrm{c}$ per ounce.

E. Cambagei. E. Gunnii.

E. Corynocalyx, E. Melliodora. E. rudis.

E. Crebra. E. obliqua. $\quad$ E. piperita.

\section{E. siderophloia.}

E. saligna.

E. tereticornis.

See under the head of Eucalpti-in our nursery department-for varieties we can furnish in plants.

Grevillea Robusta (Silk Oak of East Australia). Beautiful fern-like foliage; of rapid growth, flowering when about 20 feet in height; covered with bright orangescarlet flowers.

Pkt. $10 \mathrm{c}$; oz. $60 \mathrm{c} ;$ Ib. $\$ 6.00$

Pepper Tree (Schinus molle). Well known handsome shade tree. 


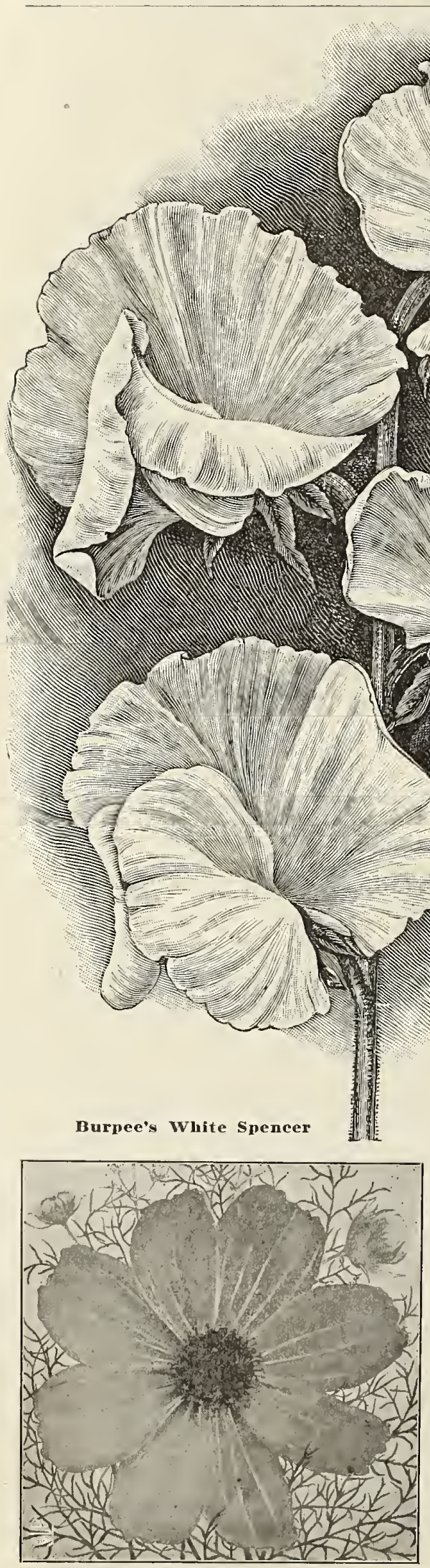

Cosmos-“Lady Lenox"
A:Grand New White Sweet Pea

\section{Burpee's White Spencer}

Although this Sweet Pea did not originate with us, it has our unqualified endorsement.

It is unquestionably the finest White Sweet Pea in existence today.

It is beautiful and graceful with large fluted and wavy petals, long stout stems, bearing uniformly four well-poised dignified blossoms of delightful fragrance.

The seed is in short supply this year and we can offer it only direct from the introducer at 25c per packet of 10 seeds.

\section{Burpee's Primrose Spencer}

Almost as large as the White Spencer and a fitting companion to it

It has the size and form of the improved Spencer type-rery large potals which are wavy and fluted at the edges, giving the blossom a very graceful and pleasing appearance.

The color is a clear distinct primrose color without the least trace of pink. This shade is very much desired and is the nearest approach to clear yellow we have. This variety is the best primrose Sweet Pea in existenee to date.

Pkt. of 10 seeds $25 \mathrm{c}$

\section{New Dwarf Nasturtium "GOLDEN MIDNIGHT"}

The foliage is a light yellowish green, while the flowers are of such a dark maroon as to seem almost black. The artistic effect rendered by this contrast between leaves and blossoms is unique and at the same time beautiful. In sealed packets only $15 \mathrm{c}$

Cosmos

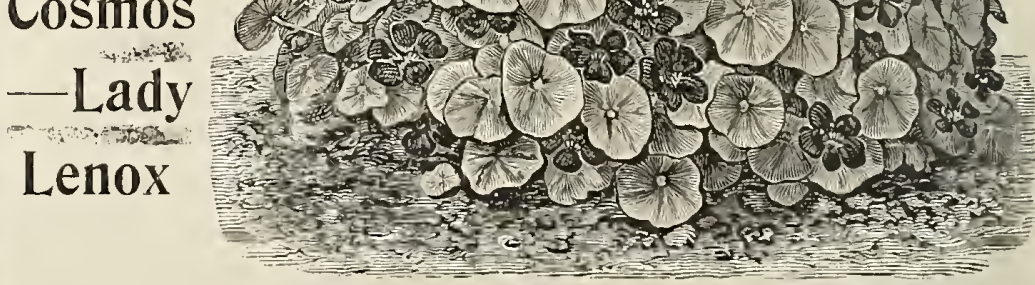

New Dwarf Nasturtium- "Golden Midnight"

A new variety which we have grown for a large New York seedman on our own farms. It is without question the finest Cosmos in existence. The plants are rather low growing (about $2 \frac{1}{2}$ feet high) and it bears profusely, the whole plant being a mass of bloom when in full flower. The blossoms are a bright rose pink and the petals are very large and wid 3 , completely overlapping each other. It comes into its full perfection of bloom about October 1 to 15 . 


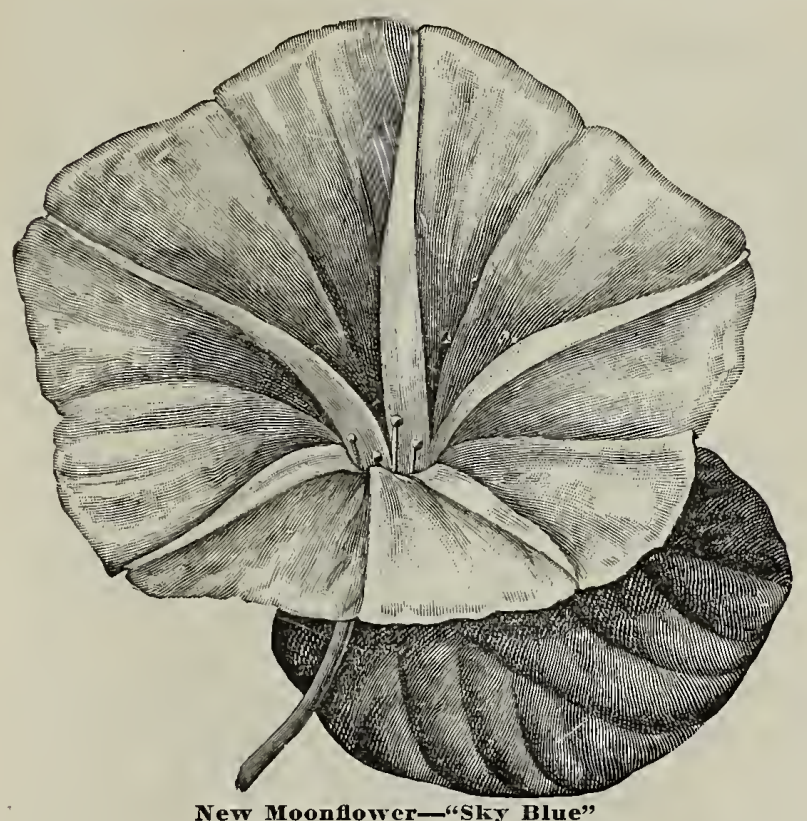

New Scarlet Sage

DARK BLOOD RED

Salvia Splendens Atrosanguinea

This new strain of Salvia Splendens or Scarlet Sage is of the same general type of growth as the original variety, but the large flower spikes are much darker and richer, and it is indeed an extra dark strain.

The plants are of strong vigorous growth and while beginning to bloom quite early in the season, will attain a height and breadth of from 3 to $3 \frac{1}{2}$ feet when in full flower.

Nothing richer or more dazzling in color than this new Salvia has ever been offered.

Per pkt. $10 c ; 1 / 8$ oz. $35 c ; 1 / 4$ oz. $60 c$

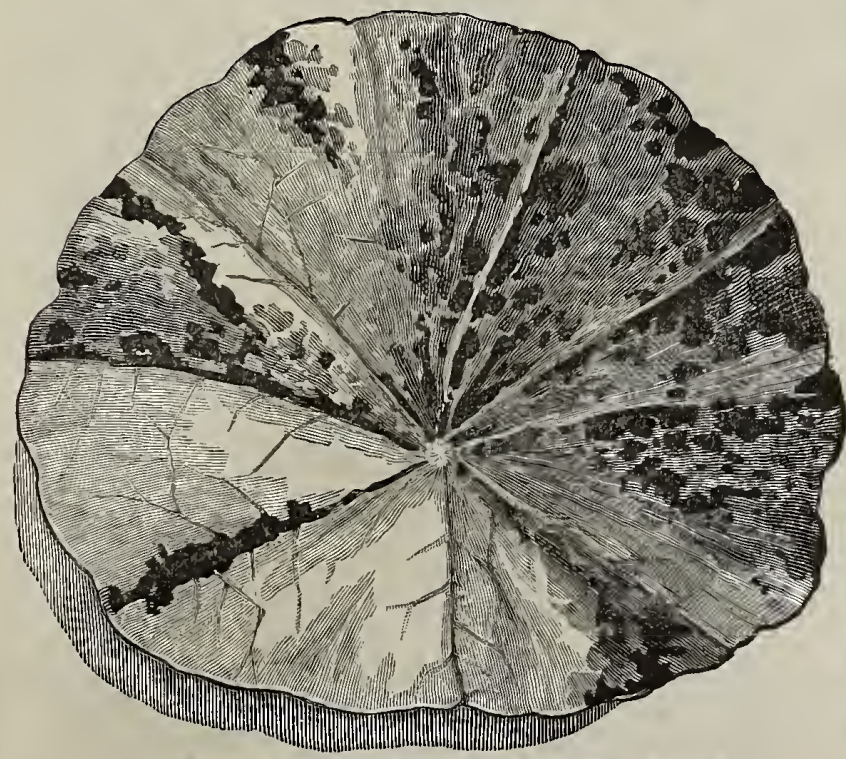

A Leal of New Variegated Queen Nasturtium

\section{New Moon Flower}

\section{SKY BLUE}

Of strong, vigorous growth, the plants quickly attain a height of 12 to 15 feet. A dense mass of large, heartshaped leaves forms a most appropriate setting for the large sky-blue flowers, which come in September in great profusion. The flowers measure nearly four inches across, and are surpassingly beautiful-of the softest coerulean blue, shading to white at the throat.

Plant two or three seeds in a flower pot (about four inches in diameter) during the fall or winter, and the dwarfed plants will produce these enormous flowers when only six to eight inches high, and continue to bloom freely for a long time. As easily grown as a Geranium in an ordinary room, these dwarf pot plants, covered with immense sky-blue flowers, are extremely attractive.

Per pkt. $10 \mathrm{c}$

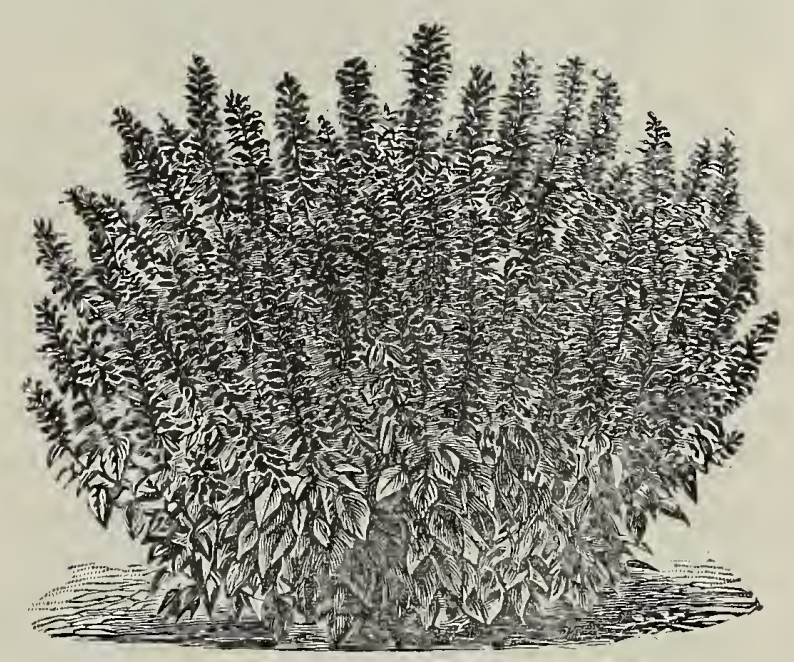

New Scarlet Sage Dark Blood Red.

\section{Nasturtium, Variegated Queen}

\section{A Tall or Climbing Variety}

While the leaves are not as tall as those of the common Fall Nasturtium the plants are just as tall and equally vigorous in growth. Every leaf is variegated with yellow, white and green. Some of the leaves are one-half to two-thirds white and yellow while others are mostly green, but beautifully striped and blotched.

The flowers are rich scarlet maroon, deepest in color at base of petals. It comes entirely true from seed.

Pkt, 10c; oz, 35e 


\section{Flower Seeds}

There are no more satisfactory flowers in the garden than those grown from sced, especially the easily grown and brilliant flowered annuals. The beautiful shrubs and lilies, of course, have their place, but are far more expensive than a paper of seed which will furnish a large number of plants with usually enough for one's garden and some to spare.

It is important to study the garden before selecting the flowers that are suitable for it, and the choice of flowers should comprehend the height of the plant, the time of blooming, and the annual or perennial class of the fower. Usualiy the tall plants go next to the house or the wall, with the shorter kinds in front and the lowgrowing varieties for the border.

While the old-fashioned flowers are still popular, new and improved varieties have been developed, with larger and finer blossoms.

The seed of a large part of our list, which we catalogue here, is raised by ourselves on our own farms, and is of strong growth, and will produce the best of flowers.

It is usually best to sow the seed of annuals early in the year, and the seed should be on hand in January or earlier.

Many flowers can be planted in the fall for early blossoms in the spring. This is peculiarly so with Sweet following sum or September,

It is best in practically all instances to start the seed in boxes, preferably a box about $18 x 24$ inches and 4 inches deep, using very sandy soil that will not bake, and provide for drainage by boring some holes in the bottom of the box. It is best not to put any fertilizer in the seed-box, since it is only necessary to bring the plants to the third or fourth leaf, when they should be pricked out and reset in another box, in which the soil should be loam mixed with leaf-mold. It is important that the plant be of good size, strong and sturdy, when finally transplanted in the garden.

If the seed be sown directly in the garden, it should be sown in the spring after the soil is well worked and fertilized. A slight depression should be made with a stick, the seed sown, and then covered with sharp sand about twice the depth of the diameter of the seed. The sand will prevent the crusting over of the soil after watering When up, the plants must be thinned from two to twelve inches, depending on the variety, otherwise they will be weak and spindly. It is a common mistake in the garden to leave the plants altogether too thick. Always keep the weeds out.

On account of the long, dry summers in California, it is necessary to apply water very often. Most of our gardens suffer for want of sufficient water. Where possible, it should be applied to the roots only, and after four o'clock in the afternoon.

With a little study of the garden and the colors and habits of the flowers, a beautiful garden can be had from the use of flower seeds at very little cost.

Annuals.-Bloom first year from seed and plant dies after one season.

Biennials.-Bloom second year from seed and plant dies after second year.

Perennials.-Bloom second year from seed and plant lives and blooms for several years.

Tender.-Means plant will not stand the least frost.

Half Hardy.-Means plant will stand a little frost and needs protection.

Hardy.-Means plants will stand considerable frost, or practically all we have on the Pacific Coast.

\section{Select List}

ABRONIA (Sand Verbena). A hardy annual, trailing in labit, about nine inches high, bearing verbena-like clusters of flowers, which are very fragrant. A native of. California Thrives in dry situations, and is valuable for rock-work or hanging baskets.

Umbellata. Rosy lilac.

Pkt. 5e

ABUTLLON (Flowering Maple, or Chinese Bell-flower). A tender perennial shrub, used generally in greenhouses, but growing into small trees in California. The flowers are beautifully bell-shaped and appear in white, yellow, rose and orange. Mlxed colors, pkt. Ioe

ACROCLINIUM. Very pretty annual, producing white and rose-colored daisy-like flowers in August and September. These are the "Immortelles," so desirable for wreathes and winter bouquets. One foot.

Double wixed, pkt. Se; Single mixed, pkt. 5e

ADLUNIA CIRRHOSA (Monntain Fringe, or Alleglemy Vine). An attractive and beautiful hardy climber, fowering the first season; clusters of small rosy-lilac fowering the first season; clusters of small rosy-lilac flowers and pale green feathery foliagc. Grows fifteen
feet tall.
pkt. 10c

ADonis (filos Adonis, or Phensant's-tye). A hardy annual of casy culture, growing about one foot high. Leaves fine-cut and feathery: flowers crimson. Seed should be sown in the autumn.

AGERATUM (Floss Flower). A hardy annual of easy culture, especially valuable for bedding, as it is literally covered with blossoms all summer. Sow the seed early in the spring, either in boxes to transplant, or out of doors, and thin to four or six inclies.

Blue Perfection. Deep blue, one foot high. Pkt. Sc Mexleanum, Imperial Dwarf Blue. Eight inches high, flowers blue. Pkt. Se

Iexlcanum, Iuncrlal wwarf whlte. Eight inches high, flowers white.

Pkt, 5e

Little Dorrit. A perfect mass of blue flowcr's; plant is six inches high and a foot through.

"Little mlue Star." A very dwarf variety, densely covered with small, light-blue flowers, which are purplish-red at the center.
AGROSTEMA (Rose of Henven). A hardy perennial, blooming the first season if seed is sown in the autumn. Plant grows one to two feet high; flowers resemble Dianthus in bright colors; and are borne on long, slender stems. Mixed colors, pkt. 5e

ALISSUM (Maritimum). A fragrant, hardy annual, having the odor of honey, and bearing spikes of small white flowers in white flowers in great profusion throughout the summer and autumn. Useful for borders or
fowers. Sow the seed early in spring.

Common Sveet Alyssum. One foot high.

Pkt. 5e; oz. 25e

"Carpet of Snow." Pure white, very dwarf, and sweet scented.

Pkt. 5e

LIttle Gell. Three to four inches high; fine for borders. Pkt. 5e; oz, 50e

saxatle. A yellowish perennial variety.

Pkt. 5e; oz. 50e

AMA IRATHUS. Hardy annuals, grown especially for their brilliant foliage.

Caudatus (Love Lies Bleeding). Light yellowishoreen foliage: long, drooping, crimson flower spikes. Plant three to four feet high.

Pkt. Je

Crucntus. Tall spikes of red flowers. Three feet.

sallcifolius (Fountain Plant). Long undulated foliage, beautifully variegated. Three feet. Pkt. Sc Trleolor (Joseph's Coat). Plant three feet high, with brilliant leaves in variegated, red, yellow, green, etc.

ANGEL's TRUMPIT. See Datura.

ANTIR RHINUM. See Snapdragon.

AQU1LEGIA. See Colmmbine.

ARA BIS-ALPINA. Grows about six inches high, very fragrant, blooms early in the spring. Valuable for rock work.

Pkt, 10e

ArCTOTIS GRANDIS (The Afrienn Lilae Dalsy). A remarkably handsome annual from Africa, forming branched bushes two to two and a half feet in lieight and breadth; are pure white on the upper surface, reverse of petals pale lilac.
Plit. 10c 
Argediona grandfloka (Prickly Poppy). Large, pure yellow, poppy-like flowers, of easiest culture in
any soll. Two feet.

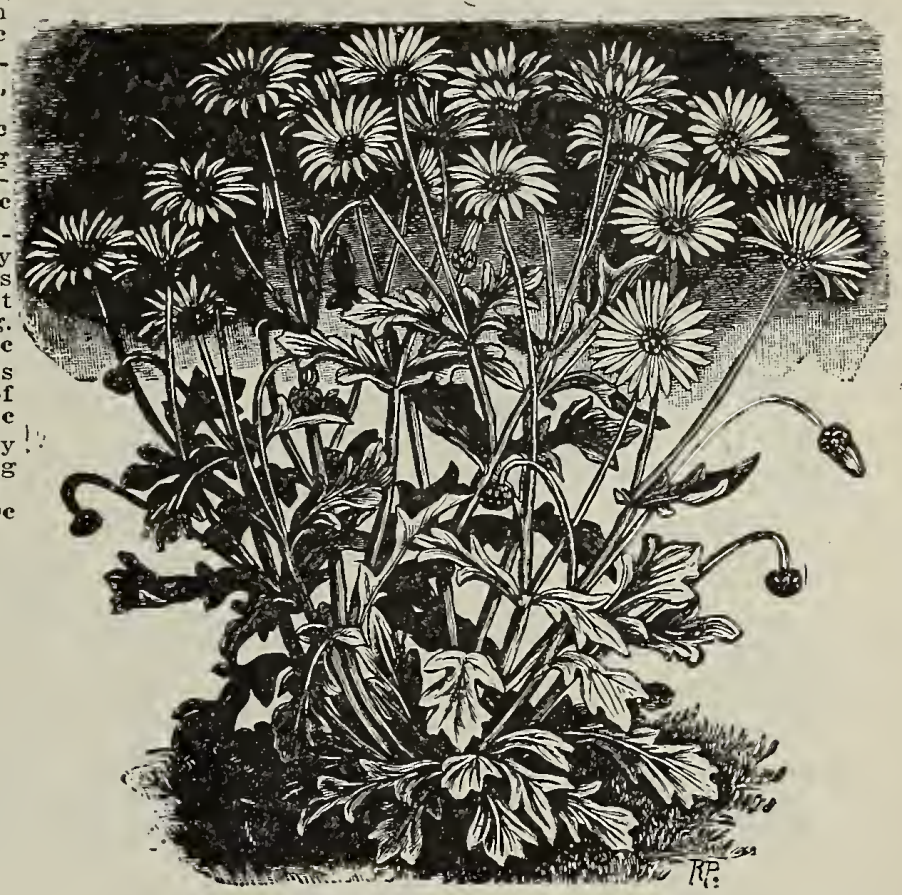

STOLOCHIA SIPHo (Dutelimnn's Pipe) . Strong-grow-
ing, hardy climber, with large, thick, shining foliage, and curious, yellowish brown, pipe-shaped flowers.

Pkt. 100

ARMEIR MARITIMA (Thrift, Sea Pink). Pretty edging plant, bearing tufts of rosy-pink flowers; hardy perennial. One foot.

A PPARAGUS PLUMIOSUS. A tender perennial for greenhouse or potted plant use, with long, fine feathery foliage. The sprays, when cut, retain their freshness in slowly, and should be soaked in water before sowing. Pkt. 10c; 100 seeds $75 \mathrm{c}$ PLUUosus NANUS. A dwarf variety and sometimes preferred on account of its beautiful, dense sprays of feathery green.

Pkt. 10e; 100 seeds 75

- SPRENGERI (Emerald Feather). An early, easily grown, feathery-leaved variety, with drooping branches. The best variety for hanging baskets.

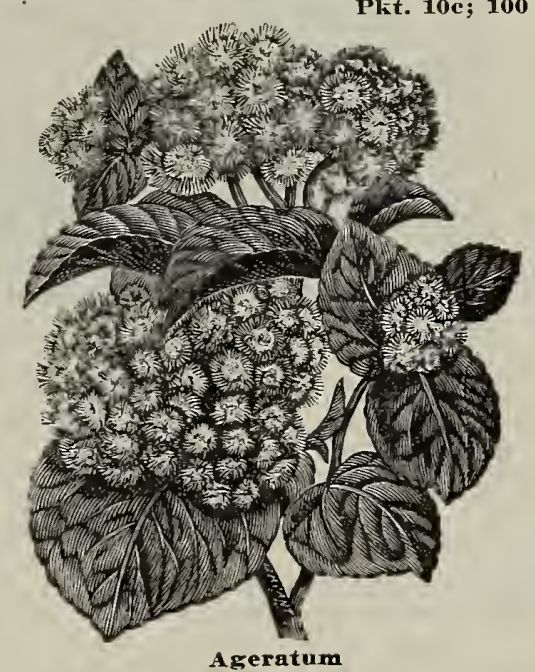

Aretotis Grandis (The Afriean Daisy)

A UR ICUL (Primula auricula) A dwarf-growing plant bearing umbels of fragrant flowers of many rich and beautiful colors. A great favorite in England, where flower shows are held of this plant alone. Extra choice mixed, from a prize collection. Pkt. I5c

AUSTRALIAN PEA VINE (Dolichos Lignosus.) A rapidgrowing, climbing annual, flowering freely in large clusters of rose flowers. For covering arbors, trellises, etc., they have no superior. Pkt. Se

AUSTRALIAN STAR FLOWER. A very attractive, everlasting or straw-flower; introduced into America by Luther Burbank. It is a hardy annual, easily grown, and produces beautiful clusters of small, light-pink, star-shaped flowers. The dwarf plant is literally covered with these flowers and is most attractive but the stems of the flower when dried are even more beautiful, and really bear out Mr. Burbank's description of them as a "fadeless flower." new-mown hay, and are used for putting among clothes, etc. U'sed in Germany to flavor the "Maitrank," or May wine. Best grown in semi-shade positions. Flowers white.

\section{Asters}

A popular half hardy annual produced in a great variety of classes and an almost endless number of colors. The tallest varieties grow about two feet high, and some varieties of dwarfs are not over three inches high. The best method of culture is to sow the seed in boxes about January lst, and thinning them from six to twelve inches apart. can be sown, however, in

BOLTZE'S DWARF BoUQUET. An excedingly dwarf variety, growing only three to four inches high, and containing a great variety of colors

Pkt. 15c; oz. \$150

COCADEU, or CROWv. A tall variety, growing 14 to 16 inches high. Of upright habit, with medium-sized 16 issom is usually white with a bright-colored outer rim.

Iixed, pkt. 10c

COyET, A good bedding variety, with large blossoms the petals of which are long, narrow, and curled backward. These colors are the best: Pink, light blue pure lilac, carmine, white. Pkt. 10c. Hixture of all colors, pkt. 10e.

GIANT COMET. A taller growing variety of the Comet type, with branching stems, which make it valuable for cutting. Best colors: Crimson, dark riolet, light blue, rose, white, The Bride (White changing to light rose) Pkt. 10c. Mixture of all colors, pkt. 10c.

DWARF CHRYSANTHEMUM FLOWERED. A semidwarf variety, with large flowers and bright colors. Plants 8 to 10 inches high. HOHENzoLLERN. A new variety of the Comet type, with blossoms fully twice as large as the old va- riety. The petals are very long and curved like a flat chrysanthemum. Plant of branching habit, and about 16 inches high.

JAPANESE, OR TASSEL (Quilled). A large-flowered variety. The petals are long and needle-shaped, and the blossom is very attractive. In various soft and
bright colors.

JEWEL, OR BALL. Upright-growing plant, similar in habit to Truffaut's Perfection. The blossoms are medium sized, and the petals curved in toward the center, making a ball-shaped flower. Mixed, pkt. 10c

TRUFF UT'S PAEONY FLOWERED PERFECTION, This variety has the most brilliant and showy assortment of colors. Flowers medium sized and almost globular. Plant, about 16 inches high, of upright growth, and flowers all borne on top. Best colors: Dark purple, fiery scarlet, white. Pkt. 10e; oz. \$1.50. Mixture of ull colors, pkt. 10e; oz. \$1.25.

VICTORIA. One of the best bedding varieties, with medium-sized blossoms, which are borne in great prufusion from the bottom to the top of the plant. Grows 12 to 14 inches high. Best colors: ROSE, colors, pkt. 10c; oz. $\$ 1.25$. 


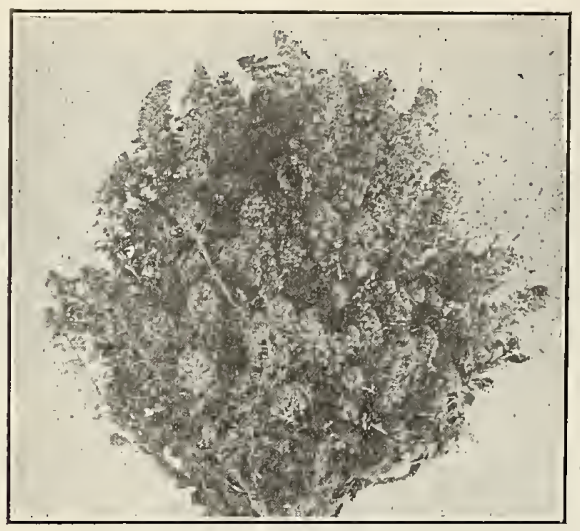

Mignonette-Pure Machet

Compact, thick-set, flowering spikes -very fragrant.

ASTERS-Continued

SEMPLES OR BRANCHING. The tallest and best florist's variety, and we heartily recommend it as the very best type of very best type or plant grows 18 inches high and about 18 inches in diameter and the blossoms, which are large and full-petaled, are borne on long stems or branches. The most satisfact. The most satisfactory type of all asters, since it is not ding flower, but owing to its long stems and large blossoms, is valuable for bouquets. Comes into flower late in the autumn. Best colors: Carmine, crimson, lavender, light biue, pink or rose, purple, white, Mary Semple (very Violet King, pkt. 10e; oz. \$1.50. Mixture of above colors, pkt. 10e STRICH PLUME. A medium tall variety of the Comet type. The petals are long, narrow, and curly, and the effect of both individual blossoms and bunches is beautiful.

Mixture of ail colors, pkt. 10c

QUEEN OF THE MARIET. One of the earliest blooming varieties, blossoming frequently in July. Of spreading habit, 8 to 10 inches, high. Blossoms medium sized, and the petals curve outward. Mixed, pkt. 10e; oz. \$1.00. Pure whlte, pkt. 10e; oz. \$1.50

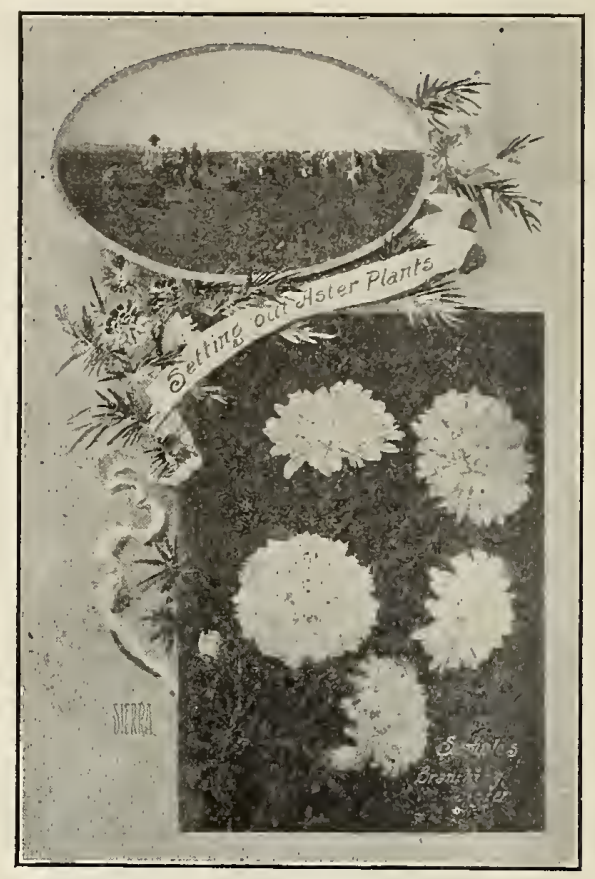

The Long-stemmed Branching Asters
BACHELOR'S BUTTON. See Centaurea Cyanus.

BALLOON VINE, OR LOVE-IN-A-PUFF. Climbing annual, with small inferior flowers. The seed pods are curiously swelled or puffed, and are quite attractive.

Pkt. 5e

BALSAM, OR LADY'S SLIPPER. A tender annual, with brittle stems and foliage. Grows about 12 inches high. Flowers both single and double, in bright colors and variations; are wax-like and very attractive The individual blossoms floating in a dish of water exhibit their beauty to the best advantage.

Camelia Flowered. Mlxed; the largest double variety.

Pkt. 5e; oz. 750

Camelia Flowered. Whlte.

Pkt. 10c

Dark Blood Red. Double.

Peach Biossom. Double; shell pink.

Red and Whlte spotted. Double.

Pkt. $10 \mathrm{c}$

Pkt. 10e

Snowball. Double; clear pearl white Pkt. 10c Mlxed Tall Doubies. Twelve inches high.

Dwarf Double. Mixed.

Pkt. 5e; oz. 60e

Pkt. 5e

Bartonta AUREA (Golden Bartonla). A hardy annual, growing about two feet high and bearing goldenyellow flowers, which have a metallic luster when the sun shines on them. Is a native of California. Sow the seed where the plants are to remain since it does not transplant easily.

BEAN. Butterfy Runner. A tall or climbing bean with beautiful red and white blossoms. Searict Runner. The popular climber. $\quad$ Pkt. 10c

Bellis PERENNIS (Doubie Daisy). A hardy perennial, blossoming freely all spring and summer. Plant is about four inches high and valuable for borders.

Extra Double White, or Snowball. A clear white variety.

Pkt. 10c

Extra Double. Mixed.

Pkt. 10e

German Dowble. Mixed; all colors mixed. Pkt. Longfellow. Double dark rose.

Pkt. 10 e

BEGONIA. Tender perennial, usually grown in the greenhouse. Some varieties are especially attractive on account of their foliage, but most varieties have exquisitely beautiful wax-like flowers, both single and double. The seed is very small and rather diff cult to germinate. It is also very expensive, some strains being worth far more than their weight in gold.
BEGONIA. FIBROUS-ROOTED VARIETIES. For outdoor culture, having beautiful leaves and bearing clusters of small, waxy flowers.

Rex. A beautifully marked, large-leaved variety.

Rex Drademn. A grand new variety. Pkt. 35c

Vernon. Deep-red flowers and dark-purple foliage. Pkt. 10e

TUBEROUS-ROOTED VARIETIES. For greenhouse and pot culture, having large, waxy flowers in brilliant colors.

Double Varletles. Mixed. Pkt. 25e International Prize. The finest large-flowered single mixture.

Single Varletles. Mixed.

Pkt. 35e

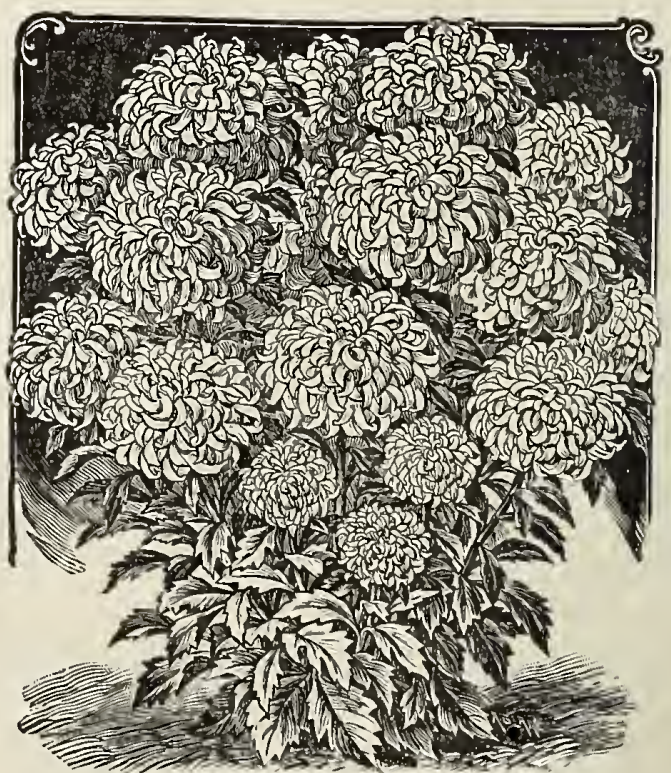

Comet Astery 
BIGNONIA (Trumpet Vine). Magnificent, hardy perennial climber, with brilliant scarlet flowers; a most ornaclimber, with brilliant scarlet for walls, houses, etc mental and effective covering for walls, houses, etc.
30 feet.

BRACHYCOME (Swan River Daisy). A hardy annual, growing from 6 to 10 inches high and producing an abundance of pretty blue and white flowers. Pkt. 5c

BROWWLLIA. A half hardy annual, making a fine bedding plant. Blooms profusely. The flowers are bright ultramarine blue, and also sky blue with white center. Will bloom freely all winter if seed is sown in
August.

BRYONOPSIS. A beautiful annual summer climber with palmate leaves; the yellow flowers are followed by pretty, cherry-like, green fruits, which change to CALIA (Tassel Flower). A beautiful and profuse flowering plant, with tassel-shaped orange and scarlet flowers; fine for mixed borders; hardy annual. Pkt. 5c

CALA IPELIS (Bugle Vine). A well known beautiful annual climber; trained to a trellis or south wall, it is an ornamental object throughout the summer, its bright orange tubular flowers contrasting effectively with the delicate green of the foliage. Pkt. 10c

CALCEOLARIA. A tender perennial, used largely in greenhouses and conservatories. Is not of easy cultreenhouses and conservatories. Is not a eargy proture, but a very desirable flower. Bears a large profusion of small, pocket-shaped fowers, many of a great variety of shades and colors in various markings.

Grandiflora. Large-flowered, self-colored, profuse flowers.

Tigered and Spotted. Mixed.

Pkt. 25c

Mixed. Grandiflora and spotted.

Pkt. 25c

Rugosa Hybrid. A shrubby, profuse bloomer, and best for outdoor culture. Pkt. 25e

CALENDULA (Pot Marigold). Very hardy annual, one foot high, blooming freely practically the whole year round. Is of the easiest culture and is desirable for rather inferior sols, where less sturdy flowers do not thrive. A medicinal extract resembling arnica is not thrive, A medicinal
made from the flowers.

Double Mixed. A good mixture of 8 or 10 different shades of yellow, some clear colors and some shaded and striped. $\quad$ Pkt. 5c; oz. 15c

Lemon King. Pkt. 5e

Meteor. Large double yellow flowers, striped with orange.

Pongei. Large double white flowers. Pkt. 5c

Pluvalis (Cape Marigold). A white single variety; the under side of the petals, lilac.

CALIFORNIA POPPY. See Eschscholtzia.

CALLIOPSIS. A half hardy annual, growing about three feet high, and valuable for bright bedding effects or for cutting. Leaves are narrow and stems slender. Blossoms single and about 2 to 4 inches in diameter.

Golden Wave. The largest-flowering variety. Clear yellow.

Pkt. 5e; oz. $25 \mathrm{c}$

Drummondi.. Mixed. A gorgeous mixture of golden yellow, brown, maroon, and other shades.

Bicolor Hybrida Semiplena.

Pkt. 5e; oz. 25c

Lanceolata. See Coreopsis.

CANARY BIRD FLOWER (TTopaeolum Ganariense). A tender, climbing annual of the Nasturtium family. Blossoms have curiously winged petals and are light yellow.

Pkt. 5c

CANDYTUFT (Iberis). A hardy annual, growing about 6 to 18 inches high, according to the variety. The blossoms are borne on variously long spikes, and the newer varieties are quite large flowering and very fragrant. Of easy culture and valuable for bedding or massing.

Common Sweet Scented. Small white flowers. Pkt. 5c; oz. 15c. Crimson, pkt. 5c. Purple, pkt. 5c.

Dwarf, or Tom Thumb. White. Plant very dwarf.

Dwarf, or Tom Thumb. Hixed. Pkt. 10c

White Rocket. Long spikes and large flowers.

Pkt. 5e; oz. 20c

Giant Hyacinth Flowered, or Improved Empress. Very large heads and long spikes of white flowers. An improved strain of Giant Empress and the best sort
for cut flowers.
Pkt. 10c; 1/4 oz. 25c; oz. 75e Mixture of all colors.

Perennial Lilac (Gibraltariea).

Perennial White (Sempervirens).

CANNA. Mixture of the popular varieties.

Pkt. 5e

Pkt. 10c

Pkt. 10c

Crozy's Varieties. Mixed.
CANTERBURY BelLS (Campanula). A hardy biennial, blooming the second year from seed. Of easy culture, blooming the second year from seed. Of easy culture, feet high, and bears double and single varieties of blue, white, purple, and red flowers. Single Mixed, pkt. 5c; Single White, pkt. 5c; Single Pink, 5c; Single Blue, pkt. 5e; Double Mixed, pkt. 5c.

Carpatica. Blue and white. Mixed.

Pkt. 5e

CUP AND SAUCER TYPE. In this variety the outer petal forms a brim like a saucer. Mixed. Pkt. 10c

$\begin{array}{ll}\text { Pure White. } & \\ \text { Persicifolia. Mixed, blue and white. } & \text { Pkt. 10e }\end{array}$ Pyramidalis. Blue and white.

Pkt. 10c

CARNATION, A half hardy perennial, used generally for greenhouse florist's trade in winter and for a garden favorite in summer. There are a large number of varieties and colors, but the early flowering mixtures are recommended for out-of-door culture. Sow the seed early in the year and transplant in March or April.

Chabaud's Everblooming. In mixed colors. Pkt. 15c Choice Double Mixture. A fine mixture of various colors and types.

Pkt. 10c

German Extra Fine Double Mixed. A splendid strain.

Marguerite. Mixed. The earliest, coming into bloom twelve weeks from seed.

Pkt. 10c

Picotee. Extra fine double mixed. White, edged with colors, or striped and splashed. Pkt. 25e

Vienna Double Dwarf Mixed.

Choice Double Perpetual. Mixed Colors. Pkt. 15c Double White.

Pkt. 10c

CASTOR OIL BEAN (Rieinus). A tender annual, growing from 6 to 15 feet high and bearing large, green, deep purple, and brown leaves and bright orange and scarlet flowers. The seed pods resemble a prickly fruit. Of the easiest culture. Individual plants, with plenty of room, look best.

Gibson's, dark red.

Pkt. 5c; oz. $15 \mathrm{c}$

Sanguineus. Tricolor. Has blood-red stocks and green leaves, with red veins. $\quad$ Pkt. 5c; oz. 15c

Zanzibarensis. Mixed. A large-leaved variety, deep green and bronze, growing 10 to 15 feet high.

Mixture of all varieties.

Pkt. 5e; oz. 15c

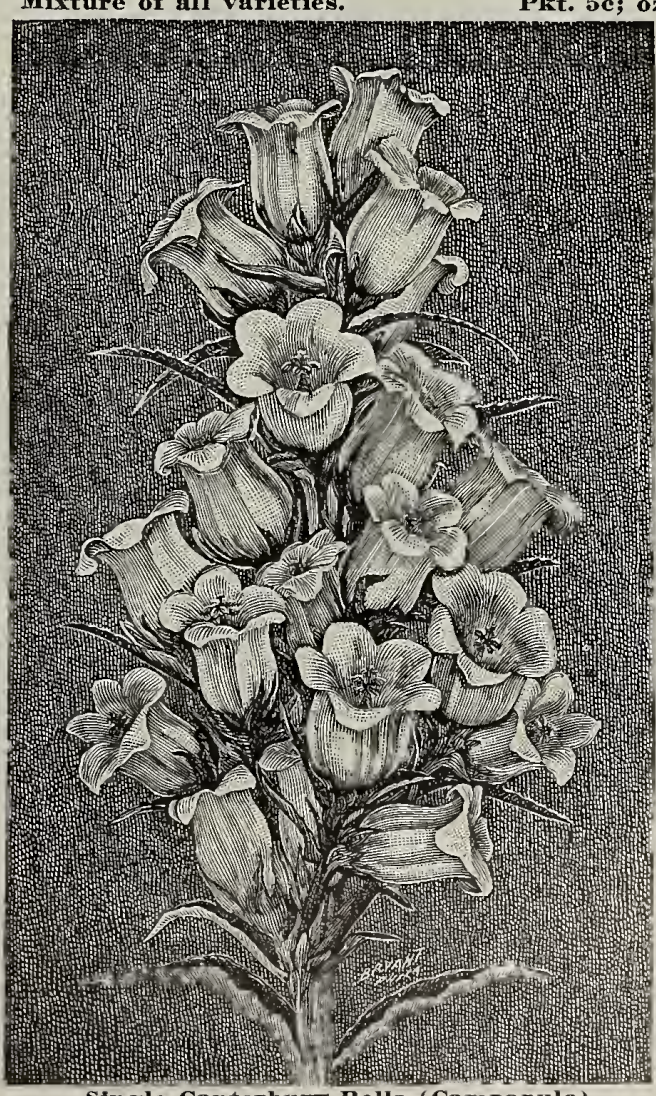

Single Canterbury Bells (Campanula) 
CELOSIA CRISTATA, or Cocksconb. A half hardy annual, growing 6 to 8 inches high, bearing a wide, wavy blossom that resembles a cock's comb. In brilliant colors, and fine for massing or border work. Dwarf Mixed. Several shades of red and yellow mixed.

Pkt. 15e

Dovarf New Giant Empress. A rich, crimson variety, with dark foliage and very wide combs. Pkt. 10c

Glasgow Prize. One of the best strains. Pkt. 10c

pLumosis, or Feathered Cockscomb. This species grows two or three feet high, and bears long, feathery plumes in brilliant colors.

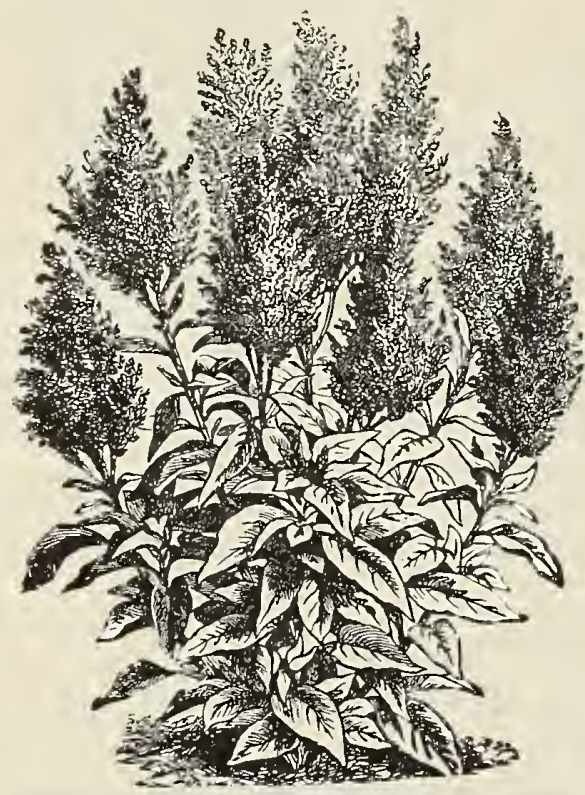

Celosia plumosis, or Feathered Cockscomb

Magnificent (Thompson's). A new variety, superior to the older sorts.

Pkt. 10e

spicata. Ostrich plumes of pink shading to silver at tips.

CGNTAUEA. A hardy annual, embracing a number of species, some being grown only for their foliage. All varieties grow from $1 \frac{1 / 2}{2}$ to 2 feet high. Sow the seed early and transplant in March.

Cyanus (Bachelor's Button, or Bluebottle, or Corn Cyanus thachelor's seed where it is to remain easy culture. Mixed. Pkt. 5e; oz. 2ac

Fint. 10e; oz. 50e. Enperor William (Large bl
Pink, pkt. je. White, pkt. 5e.

Imperialis. A beautiful, large-flowered type, resembling Sweet Sultan, but with a large-petaled margin around the blossom. In white, lavender, and pkt. 10e; oz. T5e.

Marguerite. A large, white variety of the Imperialis class. Fragrant and pretty.

mperialis

Hosell-known type. In white, yellow, lavender, and purple. Blossoms very fragrant.

Pkt. 5e; oz. 35e Pkt. 10e

Suavalens. Yellow.

Pkt. 5e

Gymnocarpa.

Candidissima, White Leaved, or Dusty Miller. Grown for its silvery, fine-cut leaves. Pkt. 10c Depressa Rosea. Rosc.

Depressa. The Queen.

Iontana. Large blue.

Pkt. 5e

Pkt. je

Pkt. 5e

CATCHELY. See stene.

CENTIANTIUS. The flowers are small, pink, salmon colored, or white, borne in clusters on light-green, almost transparent stems. Easy to raise from secd in

CENTROSEMA, or Butterfy Pea. A hardy perennial vine of rare beauty, which blosoms in July from seed shaped flower's, ranging in color from a rosy violet to a reddish-purple, with a feathery white marking through the center.

Pkt. 10e
CHRYSANTHEMUM. There are many widely different classes of this flower represented in the hardy annual or garden varieties, both single and double, and the perennial varieties, chief of which is double or florist's varieties, so highly prized in the autumn and winter.

ANNUAL VARIETIES. Growing $1 \frac{1}{2}$ to 3 feet high. Seeds should be planted early and the plants set out in April. Single varieties sometimes called "Painted Daisies." Very attractive. Mixed, pkt. 5e; oz. 30c

Coronariuu, Double. Hixed. Pkt, 10e; oz. s0e White. Beautiful for cut flowers. Pkt. 10c Yellow. Also fine for cut flowers. Pkt. 10e Eelipse. Pure golden, with a bright purplish scarlet ring, dark brown, disc; very striking.

Tricolor Burridgeanum. Single Mixed.

White.

Pkt. 5c

\section{Luteun, Carinatum.}

Carinatum (Northern Star).

Inoriorum (Bridal Robe).

Pkt. 10e

Pkt. 10e

Pkt. 15c

Pkt. 15e

Pkt. $15 \mathrm{c}$

PERENNIAL VARIETIES. Growing $2 \frac{1}{2}$ to 3 feet high. Hardy and of easy culture. Fruteseens, or "Marguerite"; also called "Paris White Daisy." White petals radiating from a golden-yellow center. Pkt. 10e

Japanese Hrbrids. A mixture of the large-flowering florist's varieties. These varieties are the large, au tumn flowers used in exhibitions and by florists. They are usually grown from cuttings, and do not come absolutely true from seed. Pkt. 25e

CIVERAIRA. A tender perennial, grown principally in the greenhouse, but can be grown safely in the carden in summer. Seed should be sown in summer and the greenhouse requires only moderate heat. Plants grow from 1 to 2 feet high and bear clusters of large, single flowers of bright colors.

Hybrida Mixed. The best variety, having large flowers and brilliant colors.

Grandiflora Dwarf. Mixed. Pkt. 25̃

Grandifiora Stella. Pkt. 250

Maritima Candidissima. Silvery foliage. Pkt. 5e

CLARKIA. A hardy annual, of easy culture, growing about 18 inches high and bearing bright rose, white, or purple flowers in great profusion. Native of California. Seed sown in the fall will give early blossoms in spring. Seed can be sown almost any time. Double Mixed, pkt. 5e; oz. 25e; Single Mixed, pkt. 5e.

Pulchella. Mixed. Matis. A popular hardy perennial climber. An old climbers that give more satisfaction.

Large Flowered Mixed.

Pkt. 10e

Virginiana (Virgin's Bower).

Pkt. $10 \mathrm{e}$

Paniculata, Beautiful, small-flowered variety.

Jackmanii. Large blue.

Pkt. 5e

Flaumula. Feathery white.

Pkt. 15e

Coecinea. Scarlet.

Pkt. 10e

Pkt. 10e

CLEONE PUNGENS, OR GIANT SPIDER PLANT. A hardy annual, growing 4 to 5 feet high and bearing in profusion rose-purple blossoms that are shaped something like a spider.

Pkt. 5c

CLANTHUS DIAMPIERI (Glory Pea of Australia). One of the most gorgeous flowers in existence; the flowers are pea-shaped, of a brilliant scarlet color with intense are pea-shaped, of a brillants a dry, warm soil and little black center; requires a dry, warm soil and little
water.

COBAEA SCANDENS. A half hardy, climbing annual, with large leaves and large trumpet-shaped flowers. The blossom is green until nearly grown, when it turns bright-purplish blue. Grows about 30 feet long, turns bright-purplish blue. Grows about 30 feet long, and is very desirable for covering a large lattice. A
native of Mexico.

COLEUS. A tender perennial, growing about 10 to 18 inches high, and grown for its beautiful, brightcolored, velvety leaves. Valuable for window garden or pots, and can also be grown out of doors if taken up in winter.

Extra Large Leaved Mixed.

Pkt. 15e Ornatns. The kest large-leaved variety. Pkt. 15c Morse's Exhibition. A beautiful and gorgeous strain. Pkt. 25e

Colussi. A free-flowering and easily grown annual, growing from 1 to 2 feet; flowers white, crimson, purple, etc.

Mixed, pkt. 5e

COLUMBIVE (Aquilepia). A hardy perennial, growing about 2 feet high and bearing an immense variety of colors on long, smooth stems.

Double Hixed. All colors.

Pkt. 5e 
COLUMBINE. Long Spurred or Single Mixed. A large, single variety, with long spurs or back. A very showy and attractivive type.

Chrysantha. Golden-yellow, single.

Pkt. $10 \mathrm{c}$

ConvolvuLUs. See Morning Glory.

COREOPSIS. A perennial with light, graceful foliage and beautiful golden and brown and gold flowers. Lanceolata.

Grandiflora Eldorado.

Pkt. 10e Pkt. 10e
DATURA. Chlorantha F. Pl. Double golden-yellow blossoms.

Pkt. 5e

Cornucopia. Blossoms single, white inside, shading to purple.

Pkt. 5e

DELPHIN I M. See Larkspur.

DIANTHUS, BARBATUS. See Sweet William.

DLANTHUS, CARY OPHYLLUS. See Carnatlon.

Cosmos. A tender annual, with fine-cut, feathery foliage and large, show y blossoms in rose, crimson, pink, and white. The late flowering or giant type grows 5 to 6 feet high and its blossoms are larger than the early varieties, or about 4 to 5 inches in or about 4 to 5 inches in diameter. They bloom late in the fall or about November 1st, and rarely blosearly varieties bloom in July. Sow about March Ist and transplant in May.

Farly Flowering Dawn. White, slightly tinted with pink. Pkt. 10e; oz. \$1.00

Early Flowering Hixed. The usual Cosmos colors in mixtures. Pkt. 10e; oz. 75 e

Giants of California. Pink, pkt. 10e; oz. 75e, White, pkt. 10e; oz. 75e Crimson, pkt. 10e; oz. 75e. Mixed, pkt. 10c; oz. 50e.

Klondyke. A late blooming variety, with bright yellow blossoms.

Pkt. 10e; oz. $\$ 1.00$
CoCKs ComB. See Celosia Cristata.

CYCLAMEN. A tender, bulbous perennial, used in greenhouses and windowgardens. Is easily grown from seed. Sow in the fall or early spring.

Perslewm Giganteum. Mixed. Very large flowers and very free blooming.

Albuin. Pure white.

hite.

Rubrum. Red. Pkt. 25e Crimson King. A new
variety.

Papilio. Butterfly type.

CYPRESS VINE (Ipomoea Quamoclit). A tender climbing annual, with soft fern-like foliage and small, star-like flowers, in red, star-like flowers, in red,
pink, or white. Scarlet, pink, or white. Searlet, pkt. 5e; oz. 25e. White, of several colors, Mixt ure oz. $20 \mathrm{e}$.

DAHLIA. A well-known and popular late summer and atumn flowering plant. Is grown from seed or propagated from the bulbous roots. The seed may be planted early in the hotbed and the plants set out in May after all danout in May after all danger of frost is over. By
sowing the seed early the plants may be made to bloom the first year.

Cactus. Mixed. Double, with pointed petals.

Pkt. 10e

Double. Mixed. Pkt. 10e

Single. Mixed. The most easily grown and also the most satisfactory from seed.

DAISY, DoUBLE. See Bellis Perennis.

Pkt. 10c

DAISY, SHASTA DAISY. A fine perennial plant bearing large white single blossoms.

Alaska. One of Burbank's new selections. Pkt. 15e DATURA ('Trumpet Flower, or Horn of Plenty). A tender annual, growing three feet high. Flowers large and trumpet-shaped.

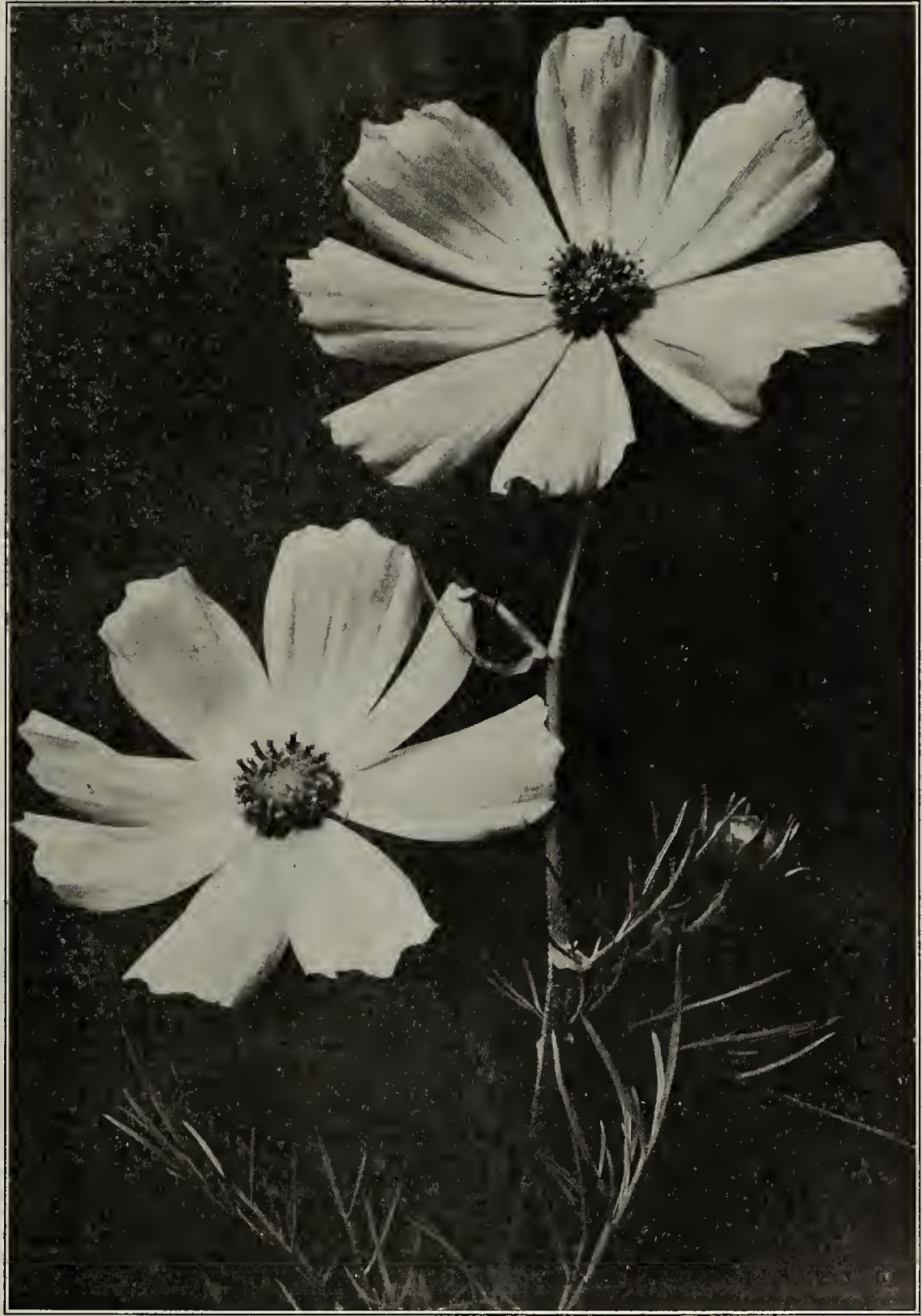

Cosmos-Giant of California

DIANTHUS, OR PINIS. Hardy annuals, about one foot high, and bearing beautifully colored, single and double blossoms in profusion all sum early in boxes and transplant, or

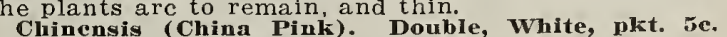
Chinensis (China Pi

Double Mixed, pkt. 5e. Diadematis FI. Pl. (Double Diadem Pink). Large,
Pkt. 5e 


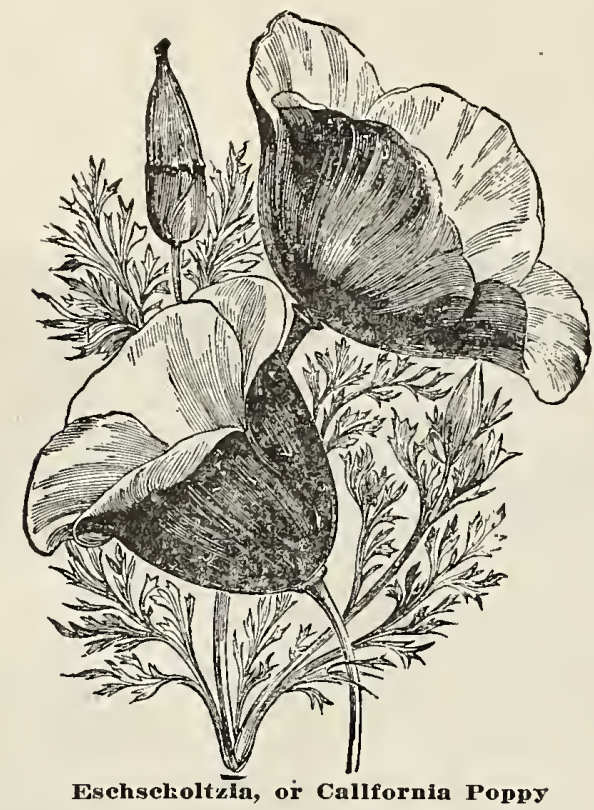

DiANTHUS. Heddewlgl (Japanese Pink). Finest single, mixed, pkt. 5c. Finest double, mixed, pkt, 5e.

Mourning Pink. Laciniatus. Single, fringed varieties. Pkt. 5c Pkt. 5e; oz. 50c Plumarius, perennial. Double whlte, pkt. 10e. Double mixed, pkt. 10c.

DIGITALIS, OR FOXGLOVE. A hardy perennial, blooming the second year from seed. Grows usually about $3 \frac{1}{2}$ feet, although in very rich soil sometimes 6 feet. The bell-shaped flowers are borne on long spikes, and come in shades of purple, lavender, rose and best in cool, shady locations.

Fine mixed, pkt. 5e; oz. 50c

DOLICHOS; OR HYACINTH BEAN. A tender, climbing; annual. Grows rapidly and is valuable for covering a trellis. Flowers in purple or white; are borne on long stems, the individual blossoms resembling the bean flower, and the ornamental pods resemble bean pods. Sow seed in open ground late in April.

Dayllgint. The best white.

Darkness. The best purple.

Labiab. Mixed.

Pkt. 10e

ECHINOCYSTIS (WIld Cucumber Vine). One of the quickest-growing vines we know of, attaining a height of 30 feet in a season; white, fragrant flowers, borne in great profusion, followed by an abundance of ornamental prickly seed pods; foliage very dense, on which account it is most desirable where much shade is desired.

Pkt. 5e

ESCHSCHOLTZIA, OR CALIFORNIA POPPY. A hardy annual, with fine-cut, feathery foliage and beautiful velvety cup-shaped flowers. Grows from 1 to $1 \frac{1 / 2}{2}$ feet high, and blooms profusely. Seed may be sown in the fall and any time thereafter till April, and blossoms may be had from early in January till late in summer. Of the easiest culture. Any soil will do, but the better the soil, the larger the plants and blossoms. It is best to sow the seed in the garden, where the plants are to remain, as they do not transwhere the plant easily.

Caifornicus. The bright, orange-yellow common variety. $\quad$ Pkt. 5e; oz. 15e; lb. \$2.00 nurbank's Crlmson Flowering. Pkt. 10e Crocen. Petals rose pink outside, white inside.

$$
\text { Crocen. Petals rose pink outside, white inside. }
$$

Double Rose. A semi-double blossom, rose colored outside and white inside the petal. Pkt. 5e; oz. 25e Ereeta Mandarin. Brownish gold, erect growing plant. Pkt. 5e Golden West. Very large, orange-colored blossoms, shading to canary yellow at the edges. Pkt. 5e; oz. 15e Mandarin. Blossoms are copper colored outside and bright-yellow inside the petals. Pkt. 5e; oz. 25e Striata. Golden yellow, striped lightly with cream. $\begin{array}{ll}\text { white. Large, ivory white. } & \text { Pkt. 5e; oz. 25e } \\ \text { Pkt. 5e; oz. 25e }\end{array}$
Mixed Yellows. A mixture of the popular orange and yellow varieties. Pkt. 5c; oz. 20c; Ib. $\$ 2.00$ Hunnemanaia.

HORBIA. A hardy annual, growing four to six feet high, and esteemed for its beautiful foliage. The blossoms are inconspicuous.

Heterophylla. Called Mexlean Fire Plant or Annual Poinsettia. Smooth, glossy leaves, turning scarlet late in the summer.

Variegata. Called Snow on the Mountain. Leaves veined and margined with white. Pkt. 10e

EVERLASTING FLoWERS. See Helichrysunu, Gomphrena, Australlan Star Flower, Xeranthenum, Acroclinium, Rhodathe.

EVENING PRIMROSE. See Oenothera.

EVERLASTING PHA. See Lathyrus Latifoiius.

FLAX. See Linium.

FEVERFEW. Matricaria Capensls. Called Double Feverfew. A plant growing 8 to 10 inches high and bear ing profusely pure white, very double flowers. Pkt 5c See also Pyrethrum.

FLOWERING MAPLE. See Abution.

FLOWIRING SAGE. See Saivia.

FORGET-ME-NOT (Myosotis). A hardy perennial, growing 6 to 12 inches high. Small star-like flowers are borne in clusters on long stems. The plant is of easy culture and blooms the first year if seed is sown early. Thrives best in a cool, moist, location.

Alpestris. Blue. White. Victoria.

Plt. Je; oz. 750 I'kt. 5e Pkt. 10c

Pkt. 10c

DIssitifiora Perfectlon.

Perenniai semperforens.

Four o'chock. A hardy annual, about two feet hio of the easiest culture Seed should be sown in the open and thinned to one foot. Is free flowering the blossoms in great variety of colors and stripes.

MIxture of ali colors. variegated and striped eol, mixed colors.

Pkt. 5e

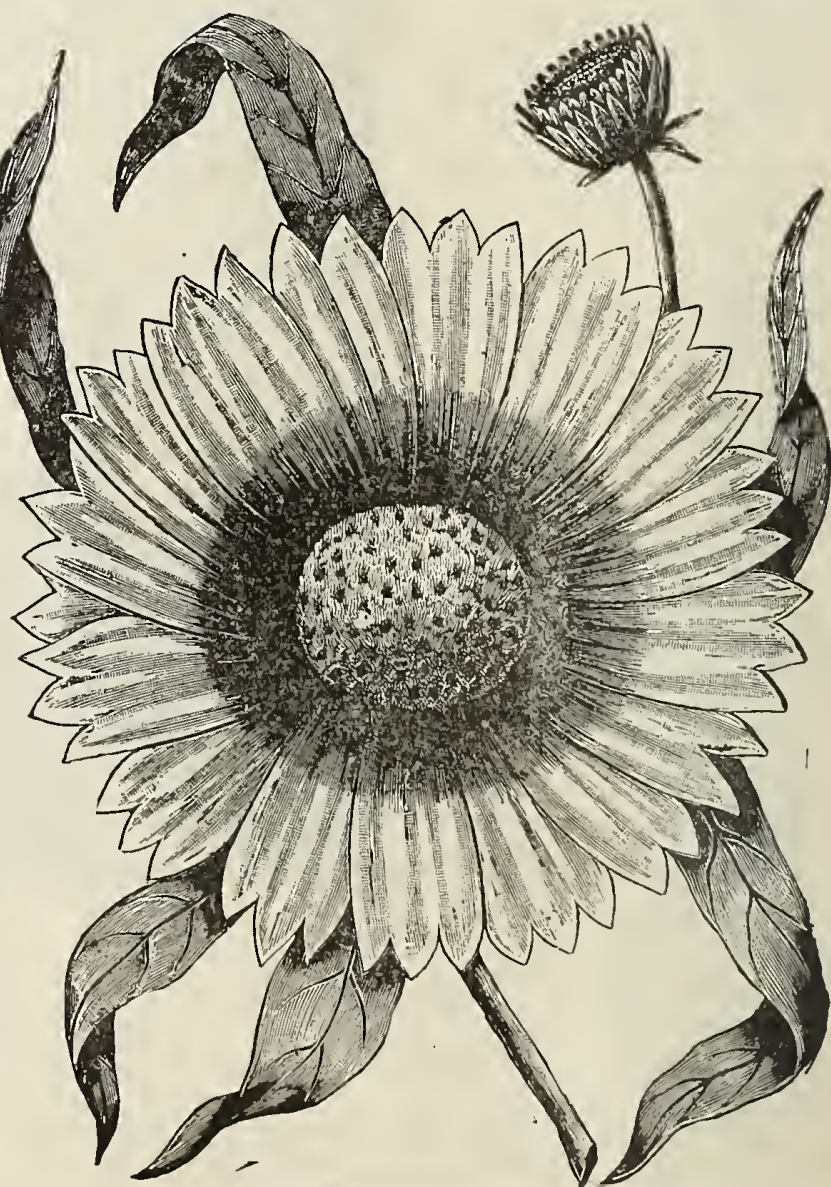

Large-Flowering Gaillardia-Singie 
FOXGLOVE. See Digitails.

FUCHSIA (Lady's Eardrop). A well known plant of easy culture in pots for the conservatory, parlor decoration, or the open ground. Very easily grown from seed. Doubie mixed, pkt. 25c. Single mixed, pkt. 25c

GAILLARDIA. A very showy garden plant, with brilliant flowers in scarlet and yellow, blended and shaded. Blooms freely from early summer till autumn. Grows one and one-half to two feet high, and the blossoms are borne on long, slender stems. Both single and double varieties are hardy. Fine Single Mixed, Pkt. 5c. Large Doubie Mixed, Pkt. 5e. Picta Lorenzianna, Plkt. se.

GERANIUM. A half hardy perennial, flowering the flrst year from seed if sown early. A popular flower in brilliant colors and variously fragrant and ornamental foliage. Grows easily from seed.

Apple Scented. Very fragrant leaves. Pkt. 25e Fancy Show, or Lady Washington. One of the most beautiful flowers we have; in rich, soft colors, with beautiful markings. Fancy mixed. Pkt. 25c Zonale. Beautiful scarlet.

Pkt. 10e

GILIA. A hardy annual growing one foot high, with white, lilac, or rose-colored flowers. A native of California. Valuable for rock-work or borders. Sow seed in the fall. Mixed.

GILLIFLO WER. See Ten Weeks' Stocks.

GLADIOLUS. Well-known magnificent plants, with sword-like leaves and long spikes of flowers of every conceivable color and shade. Many new and rare varieties are produced from seed.

Pkt. 10c

GLACUM LUTEUM (Horn Poppy). A showy plant, with long silvery leaves, gracefully recurved and deeply cut and curled; flowers bell-shaped, orange yellow.

GLOXINIA. Beautiful hot-house plants, with large, bellshaped blossoms, which come in rich, velvety-deep, and bright colors, some of which are beautifully marked.
GODETIA. A hardy annual, growing from six inches to ten inches high of compact growth, with a profusion of satiny cup-shaped flowers in deep red, pink, and white, shaded and blended. Valuable for bedding or massing. Sow seed early in the year. A small-flowered, deep-red variety; grows wild in California.

Tail Sorts. Fine Mixed.

Thumb, or Dwarf Varieties. Mixed.

Duchess of Albany. White.

Pkt. 10e

Sunset. Beautiful crimson.

Pkt. 10c

GOLDEN-ROD (Solidago Canadensis). Well-known golden-yellow hardy perennial. Three feet. Pkt. 5e

GOMPHRENA, OR GLOBE AMARANTH. A low-growing hardy annual, everlasting, or straw flower, about eight inches high, with globe-shaped flowers, in red or white. The plant makes a good border, and the flowers are very pretty, and are attractive, either while growing or dried. Mixed, Pkt. 5c. White, Pkt. 5c. Crimson, Pkt. 5c.

GOURDS. Some varieties, besides being odd, are very ornamental.

Mixed ornamental varieties.

Pkt. 5e Chinese Bottie. A very useful variety. Pkt. 5c

Dish Cioth, or Luffa. The inside lining resembles a sponge, very useful. Dipper or Siphon. Can readily be made into a dipper.

Nest Ese. These resemble a hen's ege and are quently used for nest eggs. Sugar Trough. Useful for baskets or buckets, holding from two to ten gallons each. Pkt. 5c

GXPSOPHILA (Baby's Breath). A' hardy annual of easy culture. Grows two to three feet high, and bears a profusion of small star-shaped white and pink flowers.

Iuraiis. An excellent border plant; pink flowers. Pkt. 5e

Panicuiata. Fine for bouquets; white flowers.

Pkt. 5e

\section{Ornamental Grasses}

Ornamental grasses serve the double purpose of rendering the mixed flower-bed or border attractive during the summer, and for the use of the spikes or panicles in a dried state in winter bouquets. For large beds or groups on lawns nothing gives a finer effect.

AGROSTIS NEBULOSA. A very graceful and pretty grass, charming for borders. Annual. One and onehalf feet. Plet. 5e

AVENA STERILIS (Animated oats). Drooping, very graceful. Annual. Two feet. Pkt. 5c

BRIzA AUSTRALIS. Lately discovered in Western Australia, much larger than the other brizas. The black spotted shoulders make it unusually ornamental. Per seaied packet, 25c

BRIzA MAXIMA (Quaking Grass). Very pretty. Annual. One and one-half feet.

Pkt. 5e

BRIZA GRACILIS (Smail Quaking Grass). Very delicate and graceful. Annual. One foot.
BROMUS BRIZAEFORMIS. An elegant Briza-like grass.

COIX LACRYMA (Job's Tears). Two feet. Pkt. 5o ERAGROSTIS ELEGANS (Love Grass). Very graceful and beautiful. Annual. One foot. Pkt. 5e

EULALIA JAPONICA. One of the most beautiful of the tall-growing grasses. Five feet. Pkt. 10c

GYNERIUM ARGENTEUM (Pampas Grass). The finest ornamental grass in cultivation. Half-hardy perennial. Ten feet.

Pkt. 10e

STIPA PENNATA (Feather Grass). One of the prettiest and most interesting. Perennial. Two feet. Pkt. 100 ZEA JAPONICA (Striped Japanese Maize).
HELIANTHUS. See Sunflower.

HELICHRYSUM. (Everiasting Fiower). A free-flowering, hardy annual, growing four to five feet high and bearing beautiful, straw-like flowers in a great variety of shades and colors. The stems are long and the blossoms large. It is the best and most satisfactory of the ever-lasting flowers, and makes a very handsome dried bouquet. Mixed. Pkt. 5e; ox. 25c

HELIOTROPE. A half hardy perennial, growing four to eight feet high. Small flowers, borne in graceful eight feet high. Small fowers, borne in graceful from seed if sown early. Forms a large plant, and from seed if sown early. Forms a large plant, and a wall and made to assume the character of a climber.

King of the Biacks. Dark purple, almost black.

Queen Marguerite. Purple blue.

Pkt. 10e

White Lady. Pure white.

PKt. 10e

ue types.

HESPERIS. See Sweet Rocket.

HONESTY (Satin Flower). The silvery seed pods are used for winter decoration. Very handsome, freeflowering. Two feet.
HOLLYHOCK. A hardy perennial of upright, stately growth, five to eight feet high. The very double varieties are the most desirable, but the newer, semidouble, fringed types are also very popular. Hollyhocks make a fine row in the garden, or a fine background next to a building or high wall or fence.

DOUBLE VARIETIES. Mixed, pkt. 5e. Biack, Blood Red, Canary Yeilow, Rose Pink, Salmon, Snow White. Canary Yeilow, Rose Pink, Salmon,

Allegheny. Mixed. The semi-double, fringed vavariety. An artistic and pretty sort. Pkt. 10e; oz. $\$ 1.25$

Henderson's Everbiooming. An early-flowering gorgeous mixture of single and semi-double blossoms. Prt.

SINGLES. Mixed. The old-fashioned blossoms in al colors. Mixed.

HUMULUS, OR JAPANESE HOP. A rapid-growing hardy, climbing annual, with dense leaves. Will grow twenty to thirty feet in a season, and is very valuable for covering a trellis.

Japonicus. Bright-green foliage.

Pkt. 10c

Japonicus Variegatus, Bright, variegated yellow, white and green leaves. 
HUNNEMANNA, OR BUSH ESCHSCHOLTzIA. Known also as the Santa Barbara Poppy. An erect-growing, tender perennial, about two feet high. Foliage fine cut and feathery. Blossoms, beautifully cup-shaped, bright yellow, and about three to four inches across. Stems, long and smooth. There are few more satisfactory llowers in the garden than the Hunnemannia. Fumarlafolia.

HYACINTH BEAN. See Dolichos.

Pkt. 5c; oz. \$1.00

ICE PLANT (Mesembryanthemum Crystallinum), A lowgrowing and trailing tender annual. The thick leaves seem to be covered with crystals. Used for edging and box work.

Pkt. 10e

IMPATIENS SULTANI (Zanzibar Balsam). Much prized for window culture. The foliage is waxy green, and with the semi-transparent branches makes a plant in itself attractive. The bright rosy carmine flowers are very delicate and pretty.

Pkt. 15e

IPOMOEA. An extensive genus, including many wellknown garden flowers. Are tender climbing annuals, from five to ten feet long, and all classes are desirable. The seed of several varieties, especially the moon-flower, should have the outer shell punctured and then soaked in water for twelve hours or more to germinate it.

Bona Nox (Evening Glory, or Good Night). Large, fragrant violet blossoms, expanding in the night.

Coccinea, or stur Ipomea. Small scarlet blossoms. Pkt. 5e

Grandifiora Alba (Moon Flower). Large, white blossoms, which expand only on dull days or at night.

Pkt. 10e

Heavenly Blue. A tall climber with large light blue flowers, yellow throated and measuring four to five inches across.

Sky Blue. See page 45

Pkt. of 10 secds, 10c

Sky Blue. See page 45 . colored blossoms, three inches in diameter. Pkt. 10. Learii. Large, dark blue flowers. Pkt. 25c Lutea. Large yellow blossoms. Pkt. 10e Imperial Japanese. See list under Morning Glory. Ipomea Quamoclit. See Cypress Vine.

IPONopsis (Tree Cypress). Handsome foliage and long spikes of dazzling flowers. Blooms first season if sown early. Mixed colors.

JAPA NESE HOP. See Humulus Japonicus.

KENILWOIRTH IVY. A hardy perennial, trailing plant, especially adapted for hanging-baskets. Pkt. 10c

KOCHIA SCOPARIA. A beautiful bush plant, forming a perfect sphere. The branches are covered with slender, light-green leaves, and late in the fall the plant is covered with small, red blossoms, when it resembles a "ball of fire."

Pkt, 10e

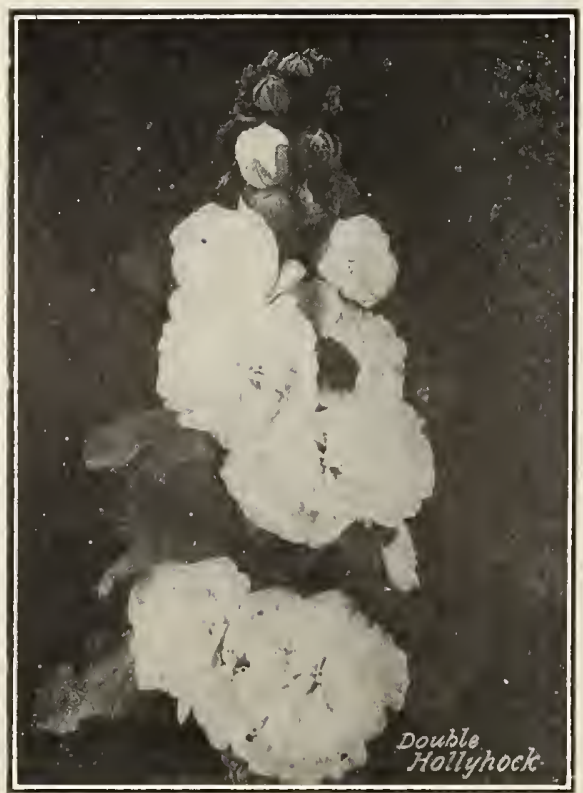

LANTANA. A tender perennial, two to three feet high, bearing verbena-like clusters of flowers, in orange. white, rose, and other colors. Blooms constantly all summer. Fiue mixed.
LARKSPUR (Delphlnium). There are two well-known types, one being the single and double annual, and the other a very tall, hardy perennial. Both are of easy culture.

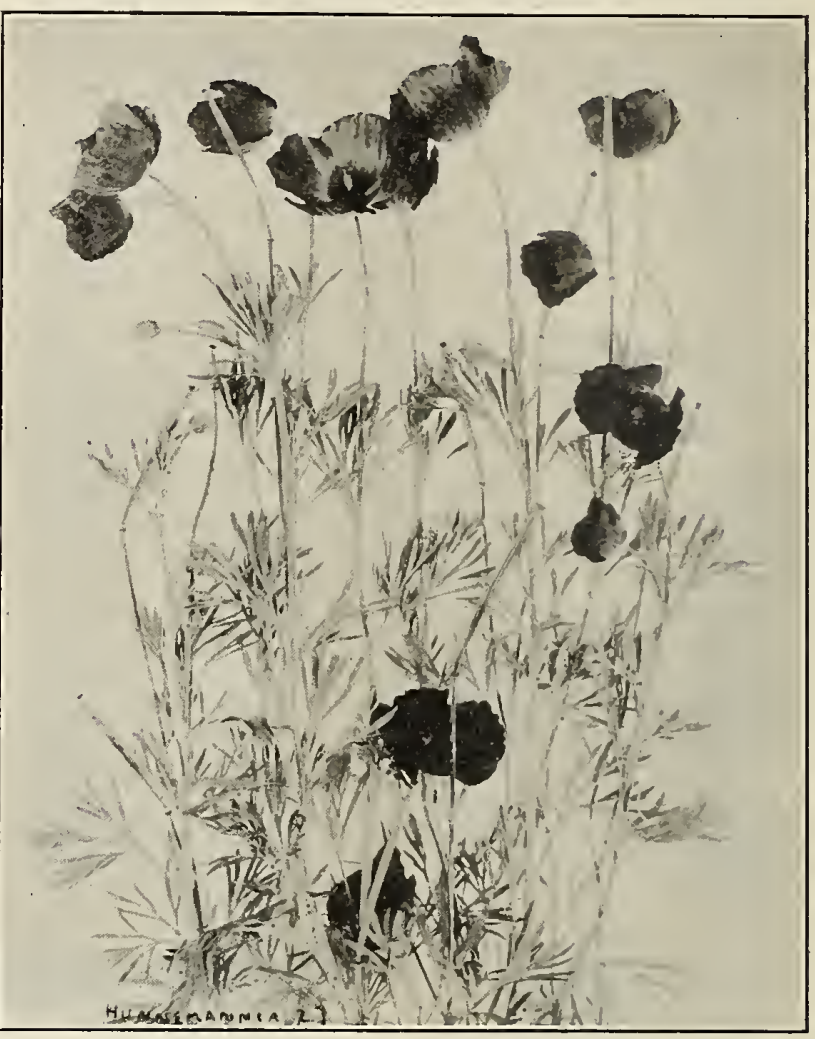

Hunnemannia, or Bush Fschscholtzia.

LARKSPUR. Hardy Annual Vurieties. Grow about one and one-half to two feet high. A great variety of colors. Dwarf Rocket. Mixed. Dwarf plant, double flowers.

Eumperor. Double Mixed. Pkt. 5e

Eumperor. Double
Single. Mixed.

Pkt. 5e

Pkt. 5e

Hardy Perennial Larkspurs. Four to five feet high, with beautiful long spikes.

Formosum. The bright-blue variety, with white center.

Pkt. 10e

Foruosum Coelestinum. The azure or very lightblue variety.

Plet. 10c

LATHYRUS LATHFOLIUS. (Ferennial or Everlasting Pea). A hardy perennial climber, fowering the first year if seed is sown in the fall. Leaves and stems smooth. Flowers resemble sweet peas, but are borne on racemes, with eight to ten blossoms to the stem. Is not fragrant, but is hardy, and thrives in any good soil.

Pink Heauty. The ground of the petals is white, edged and shaded with pink. Pkt. Ec; oz. 50e. Criulson, pkt. 5e; oz. $40 \mathrm{c}$.

white. The best variety for cutting, especially for florists' use.. Pkt, 10c; oz, 50c. Mixed, pkt, 5c; oz. 35c

splendens. Called the "Pride of Califoruia." Not as hardy as the ordinary class. Flowers bright crimson-scarlet.

LAVATERA (Annual Mallow). A showy hedge plant, growing about six feet high and covered with shrimp-pink, cup-shaped flowers. Sow in May in the open ground and thin young plants to twelve inches apart.

rkt. 5e

HrEvidr. Chiefly cultivated for the delicious and lasting fragrance of its flowers: succeeds in any common garden soil.

Pkt. 5c

LEMON VERBINA. The leaves of this fine old favorite are delightfully fragrant and refreshing. Grown
easily from seed.
Pkt. 10e

IEI'TOSINE DENSIFLORU'. Free-flowering, hardy annual, with large blue Coreopsis-like flowers on long stems; fine for cut flowers. One foot. 
LIMNANTHES DOUGLAS1I. Showy California hardy annual, of spreading habit, producing quantities of sweet-scented yellow and white flowers. Six inches.

LINUM, OR SCARLET FLAX. A hardy annual, about one and one-half feet high. Of slender and graceful appearance, with smooth stems and bright-red flowers, which are borne in great profusion. Can be sown early out of doors, and thrives well in good soil. Rubrum.

Percnnial Flax, Blue.

Pkt. 5e Pkt. כe

LIPPIA REPENS. A mossy, clover-like plant, covering the ground as closely as a lawn and having bright crimson blossoms.

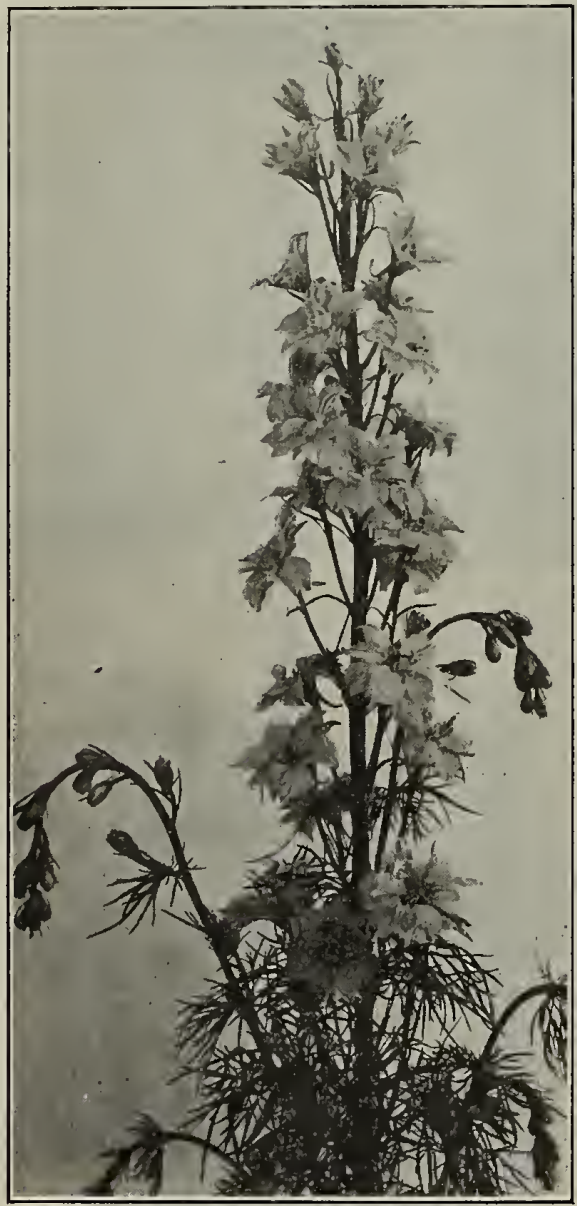

Larkspur-“Emperor"

LOBELIA. A half hardy annual and hardy perennial. The annual grows four to six inches high; is of compact growth, and literally covered with small, bright flowers. Used for ribbon work and borders or hang. ing baskets.

Crystal Palace Compacta. Bright Blue. Pkt. 10c Enperor Williám.

Golden Queen.

Pkt. 10e

Pkt. 10c

White Gem (Compacta). White flowers. Pkt. 10c Gracilis. Prima Donna. Maroon, with white eye. Speciona.

lixed annual varieties.

Pkt. 5e

Plit. 10c

Pkt. 10c

Pkt. 5e

Perennial Lobelias are hardy and three feet high. The blossoms are produced in spikes.

Cardinalis, or Cardinal Flower. Brilliant, scarlet
pkt. 10e flowers.

Hybrids. Mixed, Large flowers, resembling Cardimalis. In shades of rose, red, lilac, purple, etc.

Pkt. $10 \mathrm{c}$
LOPHOSPERMUM SCANDENS. Tender climbing perennial, growing ten to twelve feet long, with showy purplish-rose blossoms something like Foxgloves.

LOVE-IN-A-MIST. See Nigella.

LOVE LIES BLEEDiNG. See Anaranthus Caudatus.

LUPINUS, or LUPINS. Hardy annuals, in great variety, growing from one to three feet high, and bearing spikes of pea-shaped flowers. Of the easiest culture. Sow in the open ground and thin to six inches apart.

Cruikshankii. Dark blue. Long racemes of beautiful, blue flowers.

Pkt. 5e

Mixture of all colors.

Pkt. 5e

LYCHNIs. Hardy perennial, growing about three feet high and bearing bright-colored flowers in clusters. Of easy culture.

Chalcedonica. Scarlet flowers.

Pkt. 5c

Haageana. Orange, crimson, and scarlet flowers.

Pkt. 5e

MANDEVILIA SUAVEOLENS. Fine summer climber with great clusters of large, waxy, star-shaped yellow blossoms, exquisitely fragrant, resembling the single tuberose in shape.

Pkt. 15c

MARIGOLD. A hardy, annual, shrubby plant, in dwarf and tall varieties, growing from six inches to three feet high. Foliage, bright green, deeply cut, and graceful. The flowers are various shades of yellow and brown. The tall varieties are very valuable for large bedding or background work, and the dwarf varieties for borders.

Eldorado. The best tall variety, with large double blossoms. Called "The African Marigoldl" Mixed. Pkt. se; oz. $25 e$

Dwarf Freneh, Legion of Honor. Pkt. 5c

" " $"$ Striped.

Dwarf French Mixture. A mixture of dwarf double colors in yellow, orange and stripes.

Mixed. Pkt. 5e; oz. 50

Pot Marigold and Cape Marigold. See Calcndula.

MARGUERITE. See Chrysanthemum fruteseens.

IAR VEL OF PERU. See Four o'elock.

MARTYNIA. See Garden Seed List.

MATRICARIA. (Double White Feverfew). Bushy annual garden plant, bearing quantities of white double button-like flowers; useful for cutting.

Pkt. 5e

MAURANDIA (Giant-Flowering). Beautiful climber for either garden or greenhouse decoration; gemmed with Gloxinia-shaped flowers of rich purple, white, and rose, fully double the size of the older, wellknown sorts. The plants from seed sown in spring known sorts. The plants from seentinue until frost. Will begin flowering by July and continue until frost.
Mixed colors.

MLGNONETTE. A hardy annual, growing six to twelve inches high and bearing pyramidal-shaped flower spikes, made up of thickly-set flowerets, which are exceedingly fragrant. Grows easily from seed and can either be transplanted from boxes or sown out in the garden and thinned to four or six inches. Sow in the fall for early blossoms in the spring. Valuable for potting, or for bedding or for border. The flowers are not attractive except for their fragrance. Allen's Defiance. Long spikes of whitish flowers and compact growth. Pkt. 10e; oz. 50c

Golden Machet. A compact-growing variety, with medium long, thick spikes of yellow flowers.

Pkt. 5e; oz. 35 e

Parson's White. A tall variety, with long spikes with silver-white flowers. Pkt. Je; oz. 50c

Pure Machet. A compact-growing variety, with thick spikes and large flowerets of copper color.

Pkt. 5e; oz. 35 e

Ruby Machet. A dwarf, compact variety, with large, stubby spikes covered with copper-red flowerets.

Sweet Scented (Reseda Odorata). Pkt, 5e; oz. $25 e$ Mixture of the best compact varieties.

Pkt. 5e; oz. 25e

MIMULUs. A half hardy perennial, growing from six inches to one foot high. Blooms freely and exists in a large variety of colors. Useful for windowin a large variety of colors. Useful for window ghadens and pot work or for garden in a moist, early.

Moschatus, or Musk Plant. Fragrant plant, with small, yellow blossoms, spotted lightly with brown. 


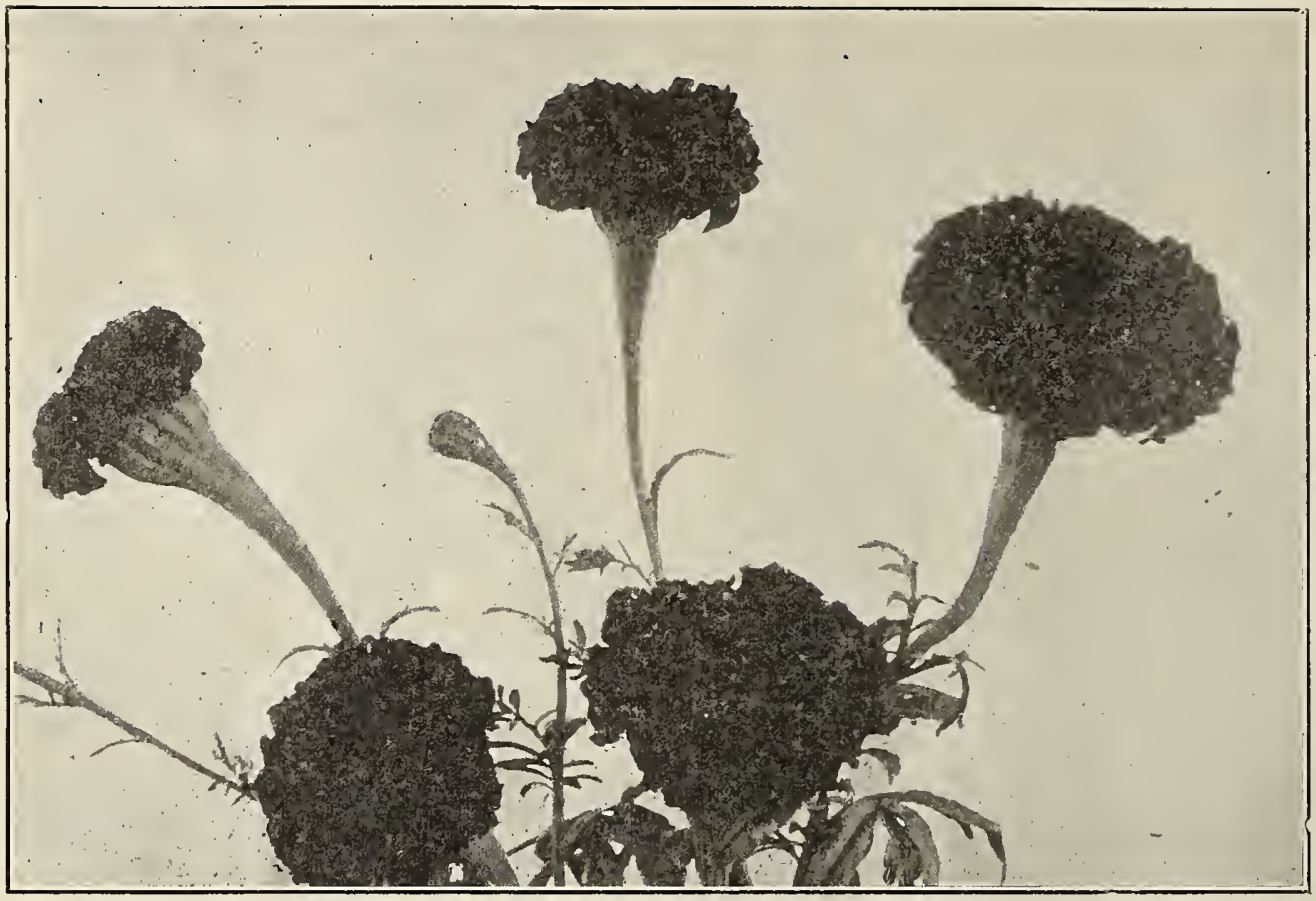

Marigold-"Eldorado," or "A frican"

MIMULUS, Tigrinus, or Monkey Flower. Large flowers of several colors, and spotted. Cardinalis.
Pkt. 10e Pkt. 10e

IIN A half-hardy, annual climber, with Arange-colored flowers, which are scarlet in the bud orange-colored flowers, which are scarlet in the bud before opening. The plant blooms freely from

to top, and grows twenty to thirty feet long.

MomornicA. Balsamina, or Balsam Apple. A climbing annual, growing about ten feet long. Has graceful annual, growing about ten feet long. Has graceful and ornamental foliage, yellow flowers, and war golden-yellow fruit, with large carmine-red seeds. Se

Charantia, or Balsam Pear. Same as the Balsam Apple, but fruit is pear-shaped.

MOONFLower. See Ipomea Grandiflora Alba.

MORNING GLORY (Convolvulus Major). A hardy climbing annual, growing about ten feet long. Flowers ing annual, growing about ten feet long. are well known and exist in a great ally expanded only in the tints, and markings. Fully expanded only in the able in every garden.

Tall, or Climbing Varieties. Mixed. Pkt. 5e; oz. 15c

Imperial Japanese. Taller, larger leaved and larger flowered, with a greater variety of blossoms than the older type.

Pkt. 10e; oz. 20e

Dwarf, or Rush Varieties (Convolvulus Miner). plants grow ten to twelve inches high, and are hardy annuals. Mixed.

MOURNING BRIDE. See Scabiosa.

MUSIK PIANT. See Mimulus Moschatus.

MYOSOTIS. See Forget-me-not.

Pkt. 5e

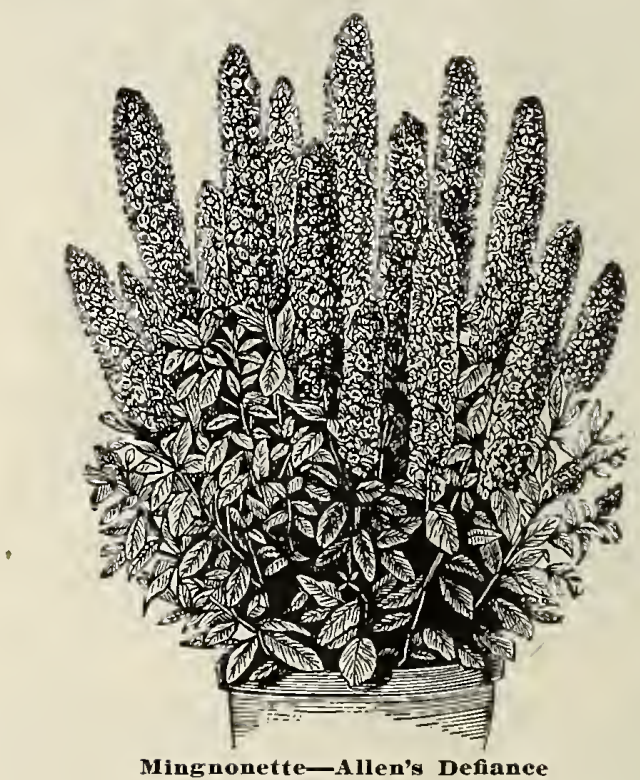

\section{Nasturtium}

Tender annual, in two distinct classes-Dwarf, and Tall or Climbing.

\section{DWARF VARIETIES}

The plant forms a small, round bush twelve to sixteen inches high. The foliage is pretty and the flowers very beautiful and contained in a great number of colors and tints. Sow the seed where it is to remain late in the spring after danger of frost is over. It is seldom necessary to thin the young plants, as they will bear standing close together.

Aurora. Yellow, veined with carmine.

Pkt. 5c; ox. 10c; 1/4 1b. 30c inconstant shades. Crimson. mixture of blotched and Pkt. 5e; oz. 20e; $1 / 4$ Ib. 60e Crystal Palace Gem. Sulphur yellow, spotted with carmine. pkt. 5e; oz. 10e; $1 / 4$ Ib. 30c
Empress of India. Intense scarlet and dark brown and green foliage.

Pkt. 5c; oz. 1Jc; $1 / 4$ Ib. $45 c$

Golden King. Rich golden yellow.

Pkt. 5e; oz. 15c; 1/4 1b. 45e

King of Tom Thumbs. Dark scarlet and dark-green leaves. 


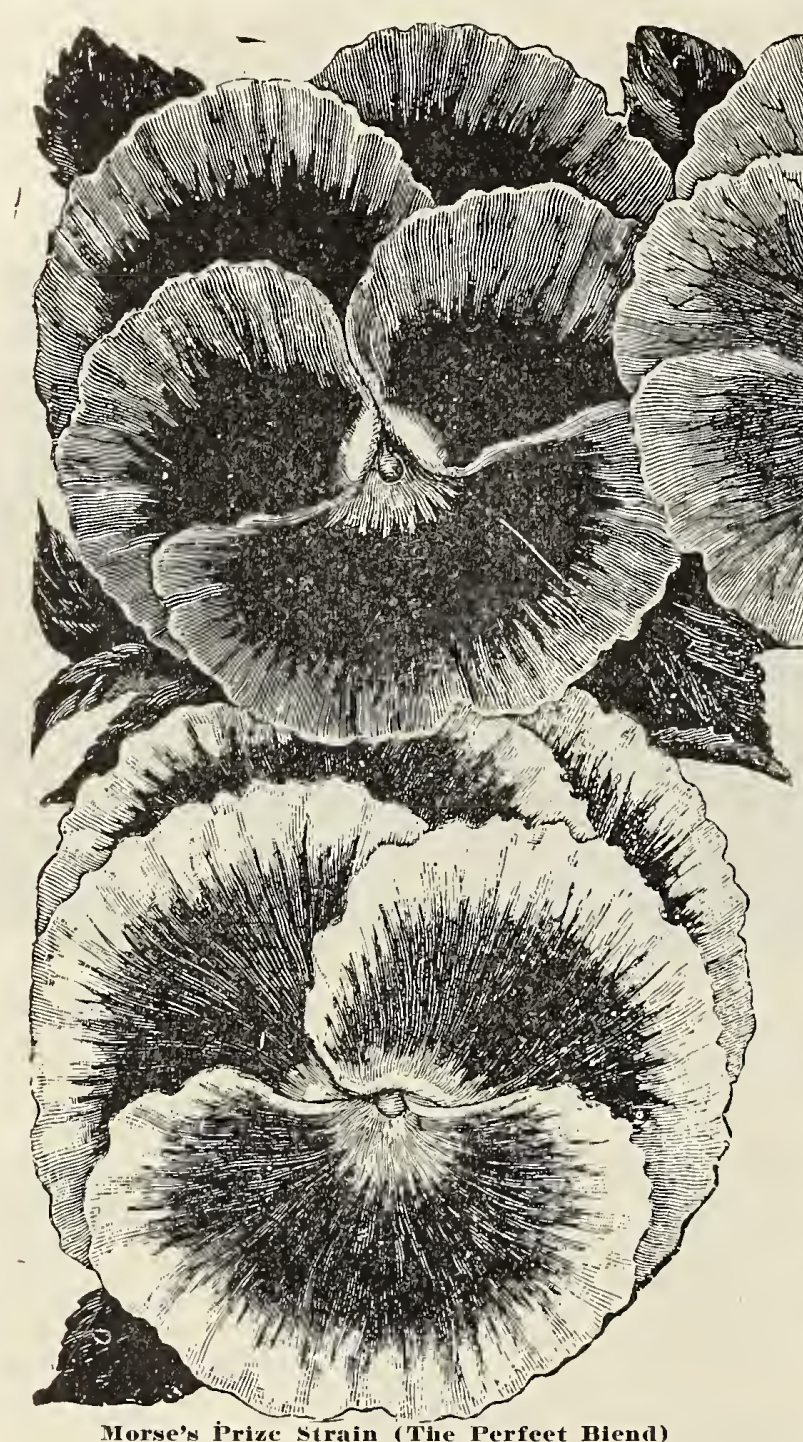

\title{
Beautiful Pansies
}

\author{
MORSE'S \\ SUPERB \\ PANSIES
}

Morse's Prize strain (Tine Perfeet Biend)

\begin{abstract}
Little praise is needed for this most popular of all flowers, as it is seen everywhere and under all conditions. It is, however, well to mention that, no matter how careful and attentive the grower may be, it is but wasted time if you have not the proper seed to begin with. All our Pansy seed is obtained from the most noted European specialists, and we claim that seed obtained from us will produce flowers of unsurpassed size and form, beauty of markings, and brilliancy and variety of colors and shades. We are pleased to say that we have many letters from customers endorsing this statement.
\end{abstract}

Culture: It thrives best in a moist, shady location and in rich, loamy soll. Seed should be sown in the autumn for early spring blossoms, or can be sown early in the year for good flowers later in the spring. The blossoms are usually larger in the spring and again in the fall, and while it blooms freely all summer, the blossoms are small during the hot months. While the plants carry over well with a little covering during the winter, it is best to plant the seed anew each year.

We offer the following extra selected strains of superior large flowers especially for pansy fanciers, all at 25e per pkt.:

Dr. Fanst, jet black; Five Spotted on White Ground; Striped Mixed; Azure Blue, white edge; Giant Faney; Light Blue; Goideise, clear yellow; Cardinal, blood red: Emperor Wiliam Purpie, violet shaded; suow White.

\section{SPLENDID IMIXTURES}

Morse's Prize Strain (The Perfect Blend). The seed of Morse's prize Strain Pansy was grown for us by a noted foreign specialist, and was saved from exhibition flowers, including alnost every shade of color, exquisitely spotted and blotched, veined, mottled, and margined, and fancy varieties. This strain is so beautiful that no description or praise can do it justice, being unsurpassed for rich and varied colors and immense size.

Plit. of 500 seeds, 50e Morse's Imperiai German Strains Mixed. A superfine mixture of the choicest German varieties in all color's. Pkt. 25e Bugnot Mixed. A circular, ruffled, and five-petaled type, with soft, blended colors and tints, veined on the margins and with a dark blotch at the base of each petal. One of the finest varieties.

Cnssler's Gisut, Mixed. A splendid mixture of various shades and markings. The blossoms are perfectly round and are blotched at the base of three to five of the petals.

Giant Trimardeau, Mixed. The largest flowering type of pansies, called the French strain The top petals are larger than the three lower ones and are beautifully marked.

Ginnt Odier, or Prize Bioteled, lixed. A large flowered type, with round blossoms. The petals are all blotched at the base and distinctly margined on the edge.

Ginnt Hasterileece These new pansies love a most beautiful combinatio wavy or ruffled petals. This wavy effect gives a graceful appearance rarely seen in pansies, and while they are really very large, they appear larger on this account.

Striped and Mottied, mixed. 1'kt. 25e THE BEST SEPARATE COLO RS OR NAMED VARIETIES

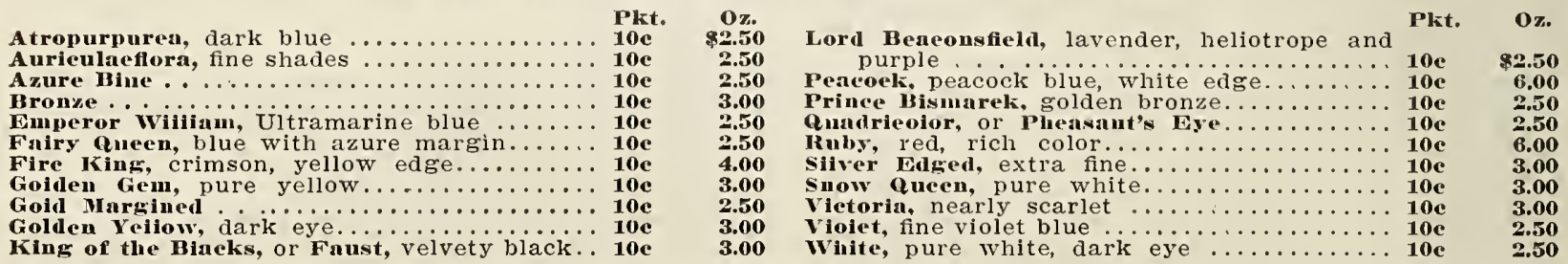
Twelve packets of any of the above $10 \mathrm{c}$ varieties for $\$ 1.00$. 
PASSION FLower (Passifiora). A hardy perennial climber, shedding its leaves in winter. Grows luxuriantly either from cuttings or seed. A very satisfactory climber for immense growth, as it will cover a porch or small cottage in one summer. Pink, Pkt. 10c; Purple, Pkt. 10c; Scarlet, Pkt. 10e; White, Pkt. 10e

PELARGONIUM. See Geranium.

PENTSTEMON. A hardy perennial, blooming first year from seed. Grows about 18 inches high, and its bright-colored and spotted blossoms are borne in spikes, somewhat like the Foxglove, but in a great variety of shades and colors. A decidedly beautiful and satisfactory flower.

Mixed. Pkt. 10c

PEREN NAL PEA. See Lathyrus Latifolius.

PERILLA NANKINENSIS. A half hardy annual, with very dark-bronze, almost black foliage. Similar to Coleus. Is of easy culture. Mixed. Pkt. 5c
POPPy. A hardy annual, three to five feet high, and bearing single and large double blossoms in bright colors. Sow seed in open ground where plants are to remain, and thin to six or tweive inches. If ieft thick the piants wili be weak and spindly and the blossoms inferior. To avoid getting the seed too thick, it can be mixed with dry sand before sowing.

\section{DOUBLE VARIETIES (POPPY).}

Cardinal. A bright scarlet, fringed, double.

Pkt. 5e; oz. 50c Straight edges. 5c

Danneborg. Pkt. 5c; oz. 50c

Fairy Blush. A large, double fringed white, with pink edges.
pin. A large, double fringed white, with
Pkt. 5c; oz. 50c Shrimp Pink. Large double, straight edges.

Pkt. 5e; oz. 50c

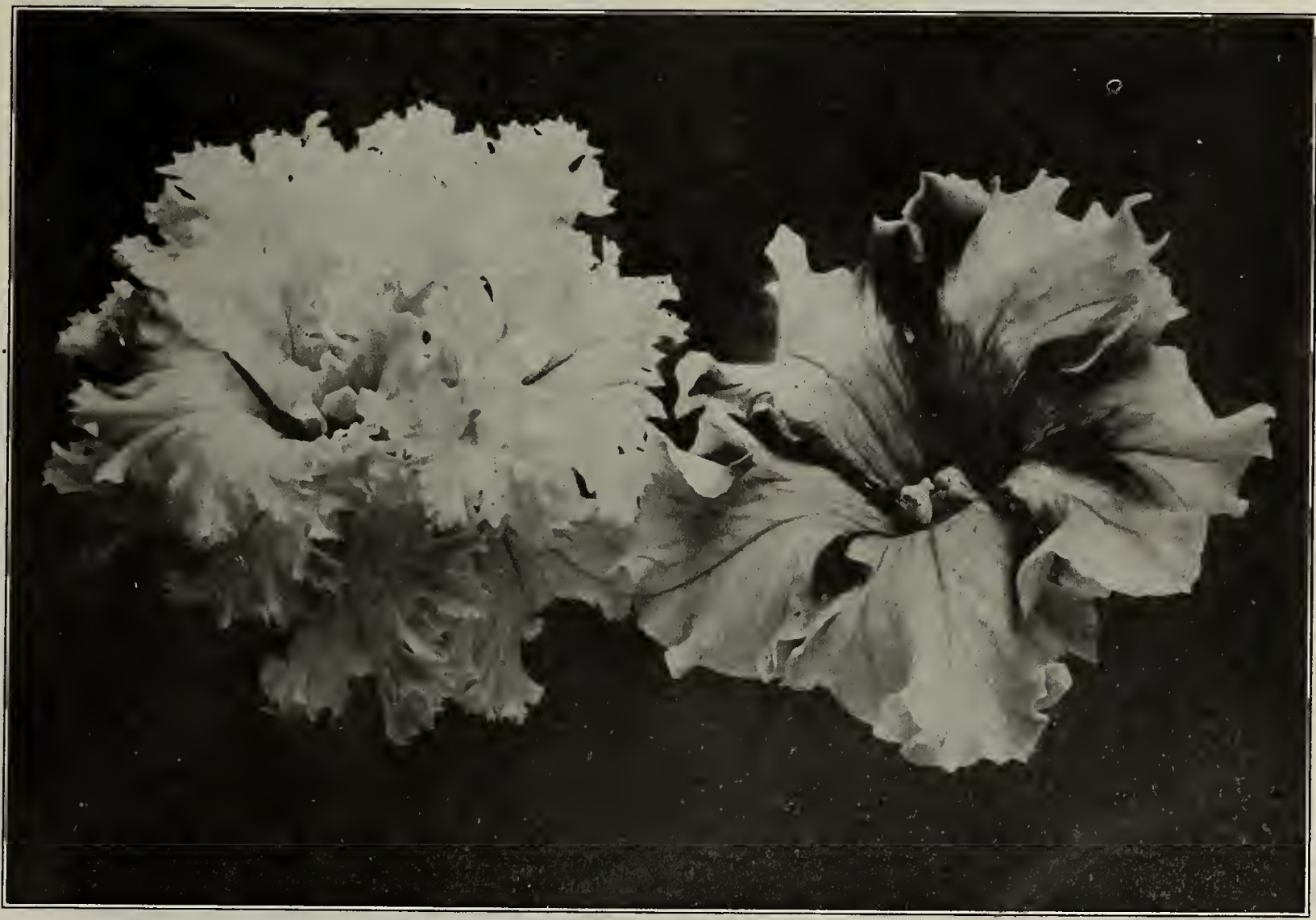

PETUNIA. A tender perennial, of several distinct types, and variously adapted for greenhouse and pot culture, and for open air. The latter grows with little attention or care, and in any soil, and blooms profusely all spring and summer. The large, double varieties do not produce seed, but the pollen from them is artificially crossed on the large, single, and fringed plants, and the seed so produced will make double blossoms. The Giant Flowered types are in large single, plain edged, or fringed edged blossoms, or in very thickly double flowers.

Giant Flowered Varieties, all fertilized by handSingle. Deep throated, brilliantly blotched, plain edge, mixed. Singie. Deep throated, brilliantly blotched, fringed, mixed. Pkt. 250 Donble. White, blotched, and brilliantly colored, mixed, plain edged. $\quad$ Pkt. 250

Double. Striped and blotched, mixed, fringed.

Pkt. 250

Small Flowered Varictics-

Dwarf Inimitable.. Mixed. A very free-blooming, dwarf plant. colors. olooming
White Fringed, or Carnation Flowered. Large, double fringed.

Pkt. Je; oz. 50e

Large Double. Mixed. All colors. Pkt. Бe; oz. 40e

\section{SINGLE VARIETIES (POPPY).}

Tulip Flowered. Intense scarlet, single blossoms. Plant about two and one-half to three feet high. The brightest colored of all poppies. Pkt, 10e; oz. 60c

Shiriey. The most beautiful type of poppies, having soft, hairy foliage, and an immense variety of single blossoms in white, pink, lavender, purple, shades of red, and scarlet. Free blooming and fine for bedding or tall border. Mixed.

Pkt. 5e; 0\%. 60

PEREN NAL POPPIES. Hardy perennial, of easy culture in bright, glowing colors. Blooms first year from seed.

Iceiand. Mixed. A graceful, delicate variety, with white, orange, and yellow single blossoms, the petals resembling crumpled tissue paper. The plant is lowgrowing, but the stems are long and slender. Sow in the fall, where plants are to remain, and thin. Pkt. Sc 
FLOWER SEEDS-Continued

POPPY. Orientale (the large Oriental Poppy). A hardy plant, bearing large, brilliant scarlet flowers, with a black blotch on each petal. Very showy and attractive.

Orientale (Queen Alexandra).

Pkt. 5e Bracteatum. Plt. 10c.

Pkt. 15c

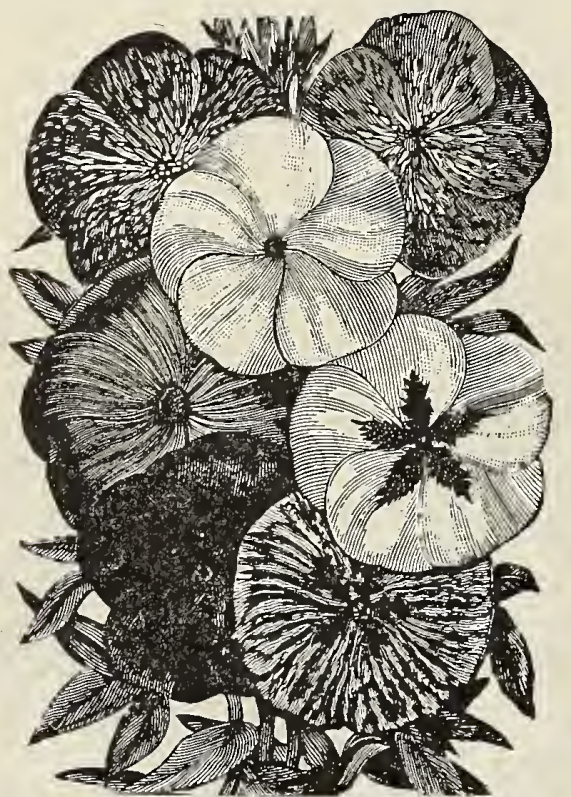

Phlox Drumuonai- "Fine Mixture."

PINKS. See Dianthus.

PHYSALIS FRANCHETTI, OR CHINESE LANTERN

PLANT. A showy annual, growing two feet high and esteemed for its seed pods, which in the fall change from brilliant yellow to scarlet and which are round and pointed and resemble a small lantern. The fruit inside the pod is sometimes made into preserves.

Pkt. 10e

PLATYCODON GRANDIFLORA, OR JAPANESE BELL. A hardy perennial, growing $11 / 2$ feet high and bearing double, deep-blue blossoms in profusion all summer. Japonicus.

Pkt. 10e

POLYanthus. See Primula.

PHLOX DRUMMONDI. A hardy annual, growing from six inches to one foot high and bearing beautiful, soft-petaled, and brilliantly colored flowers all spring and summer. Fine for bedding and massing. Sow seed in the fall for early flowers.

Carnea. Pink, with chamois-rose center.

Coceinea. Brilliant scarlet.

Terse. Bright, rosy purple and violet.

(1)

Large Blood Fed.

splendens. Bright red, with white eye.

Yellow (Isabellina). Soft primrose.

Fine vixture of all solors of the lars

rger types.

Pkt. 10c Pkt. 10c Pkt. 10c Pkt. 10c Pkt. 10e Pkt. 10c Pkt. 10e Plot 5e; ozoe Dwarf Compact. Mixed. Low-growing plants, with good-sized flowers. Star and Fringed. Mixed. A mixture of star-shaped
and pointed blossoms.

PERENNIAl hardy phlox. A beautiful and easily grown perennial about three feet high and bearing clusters of bright-colored, phlox-like blossoms. There is no more satisfactory flower for the garden, and should be in far more general use than it is now.

Mixed.

Pure White. Especially for florists.

Plkt. 10e Decussata hilxed. Pkt. 10e

PORTULACA. Low-growing or creeping, tender annual, six to eight inches high and bearing glossy, cupshaped blossoms in very brilliant and gorgeous shaped blossoms in very brilliant and gorgeous germinates slowly and should be started under glass. The plants require a sunny location, and do best on rather dry ground.

Singie. Large flowering, mixed.

Double. Large flowering, mixed.

PRIMRose, EVENING. See Oenothera.

Plat. 5e Pkt. 10e
PRimula sinensis, or ChINeSe primitose. Greenhouse or pot plants, bearing large single or double blossoms in bright colors, as well as soft tints. Sow seed in April or May for winter blooming.

\section{SINGLE FRINGED VARIETIES.}

Alba Magnifica. Pure white.

Bright Blue.

Bright Rose.

Rosy Morn. Blush pink.

Scarlet.

Single Flowers. Choice mixed.

Single Fringed Varieties. A splendid mixture.

Double Fiowers. Saved from the finest blossoms.

Ficicifolia, or Fern Leaved Varieties. Mixed.

Forbesi (Baby Primrose).

obconica Grandifiora.

Vulcaris (True Yellow Primrose)

Auricuia. Extra fine quality, mixed. ter.

Veris Polyanthus.

Pkt. 25e Pkt. 25c Pkt. 25c Pkt. 25e Pkt. 25

kt. $25 \mathrm{c}$ kt. $25 \mathrm{e}$ Pkt. 25e Pkt. 15c Pkt. 25e Pkt. 10e Pkt. 2Je Pkt. 25c Pkt. 10e

For other Primroses, see Oenothera.

PYRETHRUM. A hardy perennial, with bright foliage, much used for edging and borders. Seed can be sown in the fall or spring and transplanted.

Parthenifolium Aureum, or Golden Feather. Smallcut leaves, bright golden yellow. Pkt. 5e

Roseum, or Insect Powder Plant. A hardy perennial with red-petaled flowers radiating from a golden-yellow center. Buhach, or insect powder, is made from the dry leaves. Pkt. 5e

Grandifforum. A large-flowered type, with brightcolored and attractive blossoms for cutting. Mixed.

Seleginoides, Fern Leared. Pkt. 10e RED-HOT POKER PLANT. See Tritoma. RICINUS, See Castor Oil Bean.

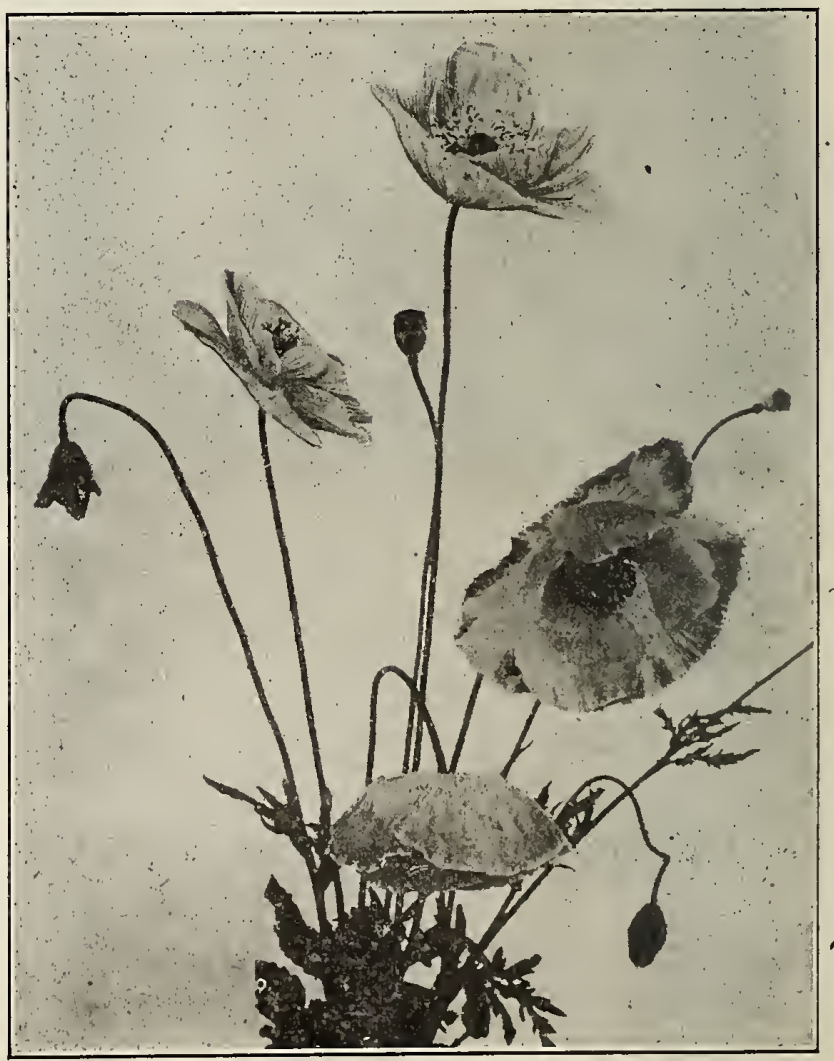


RHODANTHE (Everlasting Flower). One of the finest and most beautiful of the many varieties of everlastings; for winter bouquets, the blossoms should be gathered before fully expanded, and if dried in the shade will retain their brilliancy for years. Rose and white mixed.

ROMNEYA COULTER (California Tree Poppy). Also well known as the Matilija Poppy. This fine peren nial is of a supreme and stately beauty. It is of value as a cut flower, lasting well in water, and its delicate primrose-like perfume is most acceptable. The texture of the petals is extremely delicate, indeed, half transparent. They never lose the crumpled folds that in the case of most poppies betoken newly opened state. The flowers are large, four to five inches across, pure white, with a fine bunch of yellow stamens, resembling white, single peonies.

R UDBECKIA LACINIATA Fl. Pl. (Golden Glow). Handsome perennial, six to eight feet high, covered with very double, golden-yellow flowers.

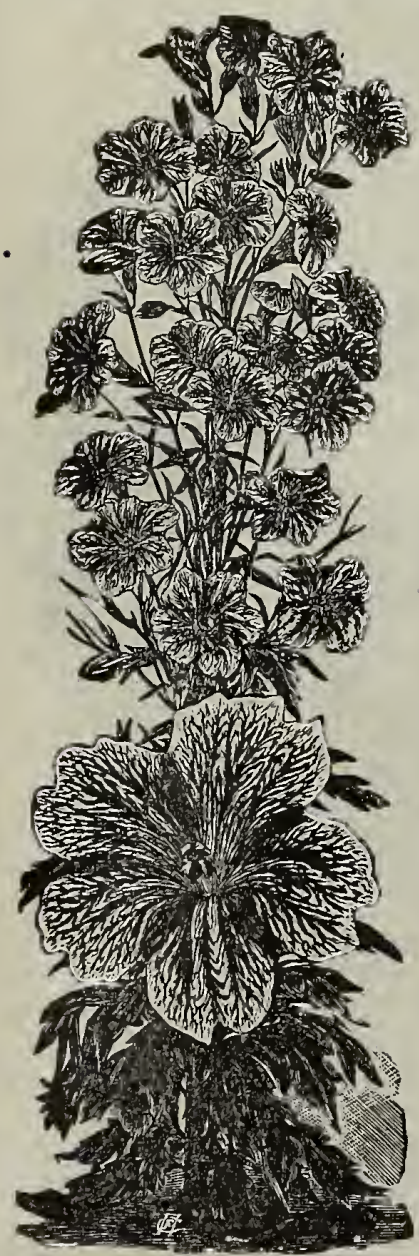

Salpiglossls.
SALPIGLOSSIS. A halfhardy annual, growing about three feet high and bearing trumpet shaped blossoms of rich shades and colors, all beautifully veined, It is valuable for bedding and massing. for bedding and massing, it excellent also for cut flowers. Sow seed early in the year and transplant, or sow the seed where it is to remain in April, and thin to six or eight inches. Extra Fine Mixed. pkt $10 \mathrm{c}$ SALVIA, OR FLOWERING SAGE. A tender perennial, blooming the first season from seed and growing two to three growing two to three are borne on long stems in racemes or spikes, and are fragrant. The plant forms a bunch and blooms profusely.

Patens. Bright blue flowers. Pkt. 15c Splendens. Bright searlet flowers. Pkt. 10c

Lord Fanntleroy. Dwart Scarlet. Pkt. $10 \mathrm{c}$ New Dark Blood Red. See page 45.

SANVITALIA. A hardy trailing annual, six inches high and bearing bright yellow blossoms resembling a miniature double Zinnia. Of the easiest culture and valuable for rockwork or borders. Procumbens Fl. borders, Procumbens Fl.
Pl.

our

CCABIOSA, OR MOURNING BRIDE. Also called Sweet Scabious, cto hardy annual, growing eight inches to two feet high and bearing heads of bright flowers on long, slender stems. The seed pods are thimble-shaped and covered with stiff

stamens. Very effective as a bedding plant or for cut stamens. While an old-fashioned flower, it is highly esteemed and very popular.

Mammoth Flowered, Double, or Maxlma. Mixed. An improved strain, with large petals and beautiful color

Dwarf Double Mlxed.

Tall Double Snowbal.

Tall Double Black Purple.

Pkt. $5 \mathrm{c}$

Tall Double Black Purple.

Pkt. 5c

Pkt. 10c

Tall Double Rose.

Pkt. 10c

Caucasia. A hardy perennial variety, with bluish
lavender blossoms and long stems. SCARLET FLAX. See LInum.

SCHIZANTHUS. Hardy annuals, growing one and onehalf to two feet high and covered with bright, showy, butterfly-like blossoms. Large flowering.
SCHIZA NTHUS WISETONENSIS. Select mixed. Blooms a long season, producing multitudes of flowers of various pleasing shades. Per wealed packet, 25e

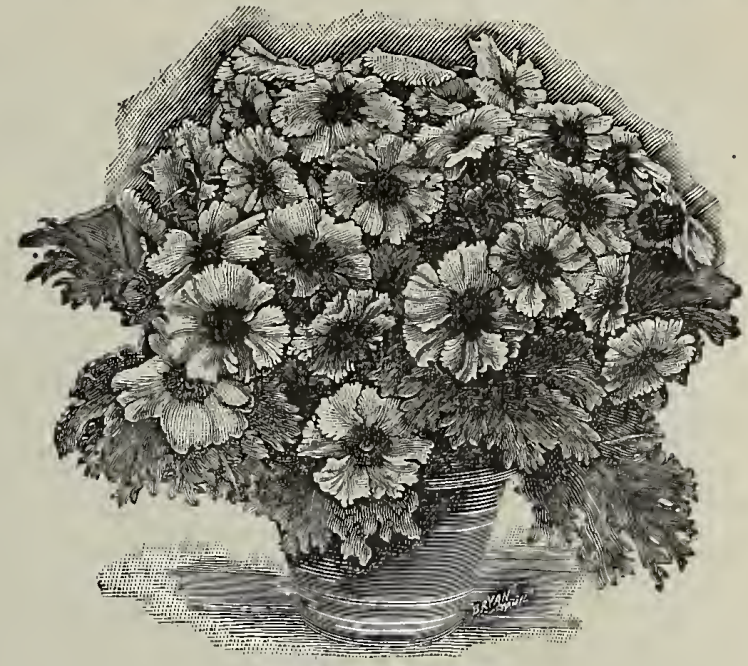

Prlmula Sinensls.

A Delicate and Beautiful Greenhouse Flower.

SEDUMI (Stonecrop). A very pretty and useful little plant, growing freely on a rock or rustic work, hangtheir brilliant star-shaped flowers in profusion. Mixed blue and yellow.

Pkt. 10c

SENECIO (Tall Double Jacobca). A perennial plant, growing tuft-like on the ground, but bearing stems about two feet high with blooms of brilliant rose purple of good size. Blooms July to October.

Elegans. Pkt. 10c

SILENE, OR CATCHFLY. Hardy annual, growing about one foot high and bearing small, attractive flowers in various colors. Of easy culture and valuable for
bedding. Mixed.

SMILAX. A climbing perennial, with beautiful, brightgreen, glossy leaves, much esteemed for its long, delicate sprays of foliage. Largely used for decorating. Start seed under glass and transplant six inches apart. It requires strings or wires to climb on when
very young.

SNAPDRAGON (Antlrxhinum). A half hardy perennial, growing from six inches to two feet tall. Flowers re oddly shaped and apparently closed but by pressing the sides together can be made to open like a dog's mouth. The newer strains are large flowered and contained in a great number of shades and colors.

Fine Mlxed.

Giant Varietles. Mixed. Tom Thumb, or Dwarf Varietles. Six inches tall. Mixed.

Queen of the North. Pure white. Pkt. 10c

Firefly. Scarlet, white throat. Pkt. 10c

Nlobe. Maroon, white throat. Pkt. 10c

Picturatum. Blotched varieties. Mixed. Pkt. 10c

Queen Victoris. New white.

Pkt. 10c

SOLANUM (Jerusalem Cherry). Very ornamental plant for house or garden culture; the flowers being followed by small brightly colored fruit or berries, which almost completely cover the plants. Flowering and fruiting the first season from seed. Plet. 10c

STATICE (Sea Lavender). A class of everlastings, of various colors, beautiful for winter bouquets. Pkt, 5c SPIDER PLant. See Cleome Pungens.

STEVIA. A tender perennial, one and one-half feet high and bearing clusters of small, white, fragrant blossoms. Suitable for summer or winter blooming, and for pot culture or open air. Serrata.

Plit, 10 e

STOCKS (Ten Weeks' Stocks, or Gilliflowers). Hardy annuals, two feet high, with spikes densely covered with beautiful, double flowerets. The flowers com in many colors and tints and are fragrant and very valuable for bedding and cut flowers. The flowerseed growers have devoted a great deal of attention and care to this flower, and have developed a large number of varieties, and have so improved the double number of varieties, will come fully eighty per cent varieties that they will come fully not come fifty double, where they formerly would not come fity per cent so. Of easy cult 
STocks, Cut and Come Again. White. Princess Alice or White Perpetual. Best for cutting. Pkt. 15e Cimperor, or Perpetual. A biennial double variety, the plants sometimes lasting many years if protected. White, for florists.
Pkt. 10e Mixed. Pkt. 10e

German Double. A very good double strain. White, pkt, 10e. Mixed, pkt. 5e.

Globe Pyramidal. One of the best large, double varieties. Pkt. 10e

Garly Large Flowering Winter.: Almond Blosson, pkt. 25e. Beauty of Nice, pkt. 15e.

Dwarf Large Flowering Ten Weeks. Mixed. Pkt. 10c Dwarf Double Blood Red.

Dwarf Double Pink.

Dwarf Double Canary Yellow.

Drvarf Double White.

Giant Perfection. Finest mixed.

Winter or Perennial Brompton.

Dresden, or Perpetual. Mixed.

Pkt. 10e

Pkt. 10c

Pkt. 10e

Pkt. 10e

Pkt. 10e

Pkt. 10e

Pkt. 10e

S'TOKESIA, or CORNFLOWER ASTER, A hardy perennial, two feet high, and bearing large blue flowers on long stems, Blooms freely all summer and fall, and is of easy culture.

STRA W FLowers. See Australian Star Flower; Gomphrena; Helichrysum; Xeranthemum.

SUNFLOWER (Helianthus). Hardy annuals, growing from three to six feet high. Of the easiest culture and suitable for a stately row or background, or even for bedding.

Chrysanthemun Flowered. Large, densely double, bright golden flowers. The plant branches and affords fine, long stout stems for cutting. This is the best variety in existence. Pkt. 5c; oz. 25e Russian. The common, large flowering variety,
with great brown centers and an edge of yellow petals. The seed is used for chicken feed.

Pkt. 5e; oz. 10e

Stella. The shorter, smooth-leaved, small-flowered variety, growing wild in many States. Pkt. 5e; oz. 25e

SWEET ALYSSUM. See Alyssum.

SWEET ROCKET (Hesperis). A hardy perennial, growing two to three feet high. An old-fashioned, fragrant flower, of the easiest culture, and bearing clusters of white and purple blossoms. Mixed. Pkt. 5e

SWEET SULTAN. See Centaurea Moschata.

SWEET WILLIAM (Dianthus Barbatus). A hardy perennial, blooming the second year from seed. Grows one to two feet high and bears its flowers in clusters at the end of a stiff stem. The individual flowerets are handsomely colored and marked. It makes a beautiful bedding plant, and is of easy culture.

Single Varieties. Mixed. More attractive than the double.

Double Varieties. Mixed.

Pkt. 5e

HUNBERGIA, OR BLACK-EYED SUSAN. A hardy annual climber, growing about four feet long, and valuable for low fences or hanging baskets. Prefers a sunny situation. Blossoms are buff orange, or a sunny situation. Blossoms are buff, orange, or
white, with dark centers.

TOREvIA. A hardy annual, with trumpet-shaped flowers, and glowing four to six inches high. Good for hanging baskets or borders.

Fommieri. Velvety blue, with three dark spots of indigo and a bright yellow throat. Aliba.
Pkt. 5e

White Wings. Dainty, white flowers, tinted with rose at throat.

VALERIAN. Showy plants for mixed borders or shrubberies, bearing large corymbs of bright flowers; bears shade and moisture well. Hardy perennial. Flowers

WRBENA. A half hardy trailing perennial of easy culture. While it grows readily from division of the root or from cuttings, it does best from seed. It is well known as a bedding or horder plant, and the improved large flowered and fragrant strains make it a handsome cut flower for low vases.

Mammoth Auricula Flowered. Various colors, with large white center. Pkt. 10e; $1 / 1$ oz. 50c; oz \$1.50 Mammoth Flowered. Mixed.

Pkt. 10e; 1/4 or. 35e; oz. \$1.25

Mayflower. Delicate white, edged with rose.

Pkt. 10e; 1/4 oz. 35e; oz. \$1.25

Pink shades. Mammoth strains of rose and pink
Pkt. 10e; $1 / 4$ or. 35e; oz. \$1.2. shades.

Pure White. Mammoth strain.

Pkt. 10e; 1/4 oz. 35e; oz. \$1.25

Purple and Blue Shades. Mammoth strains.

Pkt. 10e; $1 / 4$ oz. 35e; oz. \$1.25

Searlet Defiance. Brilliant scarlet.

Pkt. 10e; $1 / 4$ oz. 35e; oz. \$1.25
Striped Varieties. Mixed.

Fine lixed.

Pkt. 10e

Mixed.

Pkt. 15̄e

VINCA, OR PERIVINKLE. A tender perennial, with ornamental foliage, useful for bedding in summer and for the greenhouse in winter. Blooms freely the first year from seed.

Mixed. Rose, crimson, white, etc.

Pkt. 10e

VroLAs. A hardy perennial, blooming freely throughout the summer and autumn. Of easy culture, and seed may be sown out of doors, where the plants are to remain.

Mixed. All varieties.

Pkt. 10e

Cornuta Purple Queen.

Pkt. 10c

Cornuta white.

Cornuta Yellow.

Purple 10e

Pkt. 10e

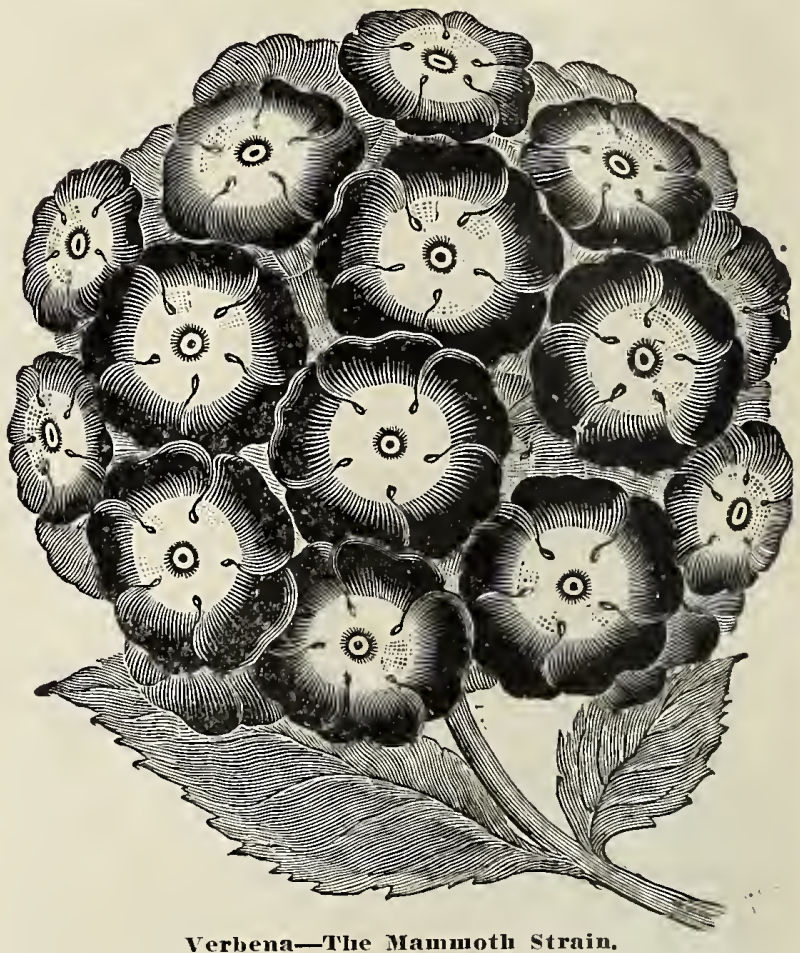

VIOLET, OR YIOLA ODORA'A. Although these flowers do best propagated from the cuttings, they grow readily from seed, and produce a small, fragrant blossom. Single, sweet-seented.

VIRGINIA sTocrs. A hardy annual, growing about nine inches high and blooming profusely. Of easy culture, and and can be had in continuous bloom by and summer. seed at frequent intervals during spring and summer.
Red and White Nixed.

Pkt. 5

VrSCARIA (Rose of Hearen). Pretty, profuse flowering plants; adapted for beds, edgings, or clumps, growing readily in any garden soil; flowers pink and white; annual.

WALLFLOWER. Half hardy perennial, blooming the first year from seed. Grows one to two feet high and bears long stems of fragrant flowers. It is best to renew the plants every two or three years by resowing the seed. An old-fashioned flower, which is always popular. Sow early in the year in boxes and transplant.

Fine German. Double. Tall. Mixed. Pkt. 10e Fine Single, Mixed. Pkt. 5e

Tow Thumb Golden. Small, compact plant, single Pkt. 10c

Dwarf German Double.

Pkt. 10e

WHITLAVIA. An easily grown, hardy annual, bearing small violet-blue, cup-shaped blossoms. Plants one foot high. Sow seed in open ground in spring and thin the young plants. 
$W_{\text {tionably }}^{\mathrm{E} \text { are } \mathrm{he}}$ largest growers of Sweet Pea seed in the world, and our immense seed farms about Gilroy in the South Santa Clara Valley are now world renowned.

This popular flower which is so easily grown anywhere, is especially adapted to California and most of the seed for the world's supply is grown here, It is of the easiest culture, its cut worms and birds, which interfere with the young seedlings. There is no practical remedy for the former although lime and Paris Green will help somewhat if sprinkled on the young sprouts.

The seed should be sown in the fall in a row, dropping two or three seeds every four inches and covering one or two inches deep. While the growth is very slow in the winter it is very rapid in the spring, and the plants are in full bloom in May, before the dry, hot summer sets in. The seed, however, can be planted any time until April 1, especially near the sea coast where the weather is is prevalent. Sweet Peas require an a bundan ce of water and an open location.

The water, if possible, should be ap. plied at the roots, and the vines should not be sprinkled. A trellis of brush or strings or sary.

The flowers should be kept gathered, since if allowed to go to seed the plants will soon stop flowering.

The Sweet Pea is a climbing annual and hardy. The early flowering varieties are generally used for forcing under glass, but they are very desirable also in the garden and will bloom in February if seed is sown in November.

There is a very long list of varieties, but as the Sweet Pea has been developed and improved a great many of the older varieties have been we offer represents all the desirable varieties, and e ver color and shade is included.

\section{S W E E T P E A S}

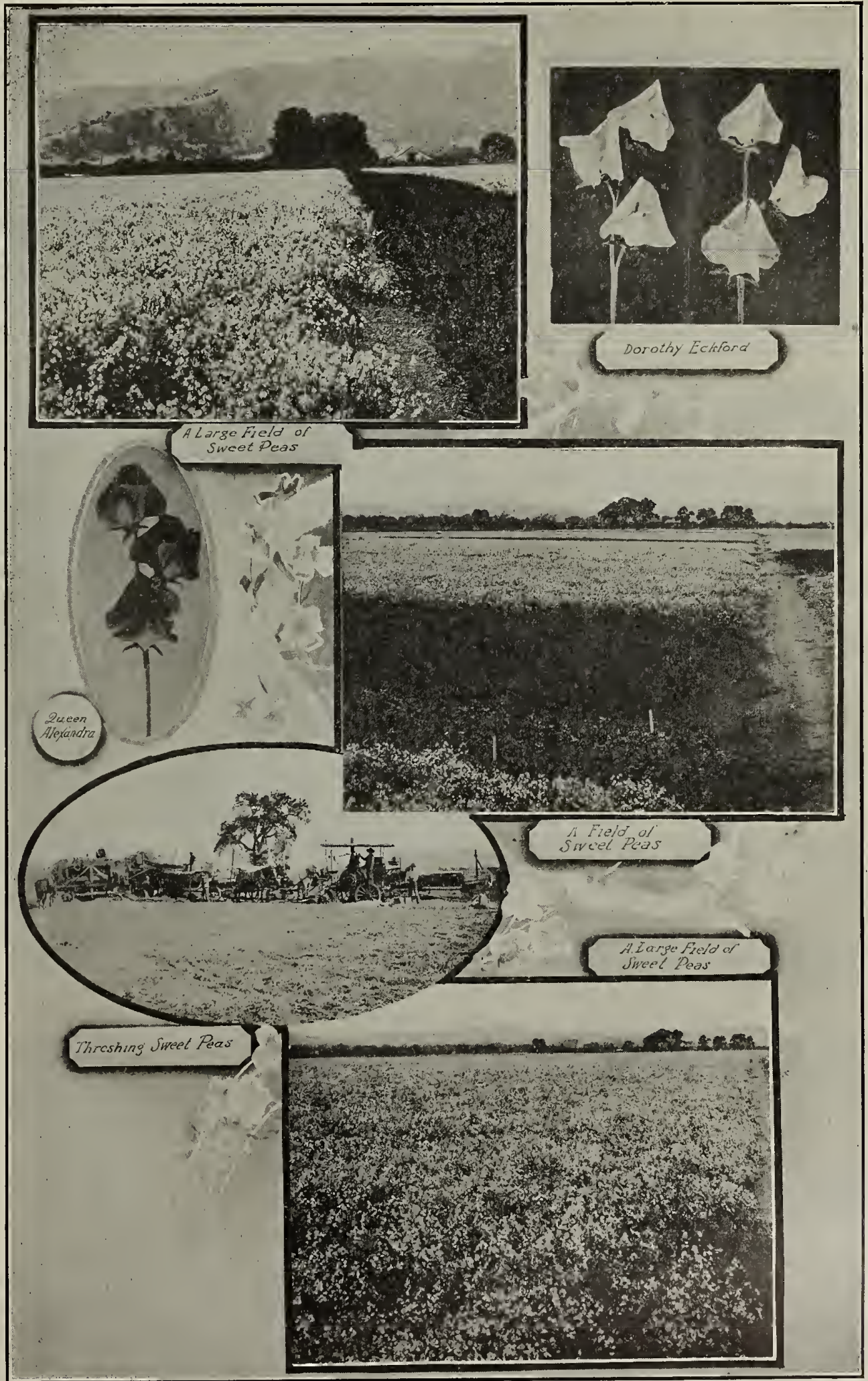

Views from Our Seed Farms. 
Note-If any of our customers are familiar with a name of a variety that does not appear here, and will write us for it, we can probably send precisely the same shade of color in an improved variety under one of the names we list here.

The star (*) indicates our choice of the best varieties in each class.

(Price per packet of each is 5e, except where noted otherwise.)
(Prite.

* BURPEE's White SPENCER. See page 44.

* BURPEe's Earliest white. One of the earliest varieties . .............pkt. 10e $\$ 0.25$

- DOROTHY ECKFORD. The new white of the largest and best type $\ldots \ldots \ldots \ldots \ldots \ldots \ldots \ldots \ldots . .10$

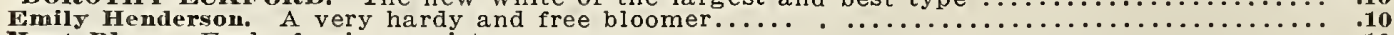

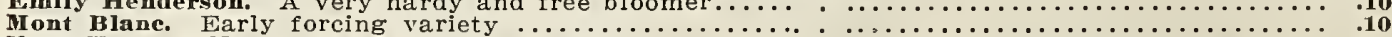

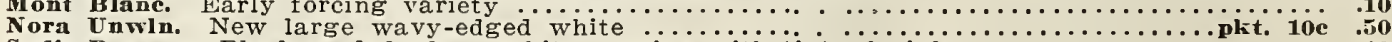

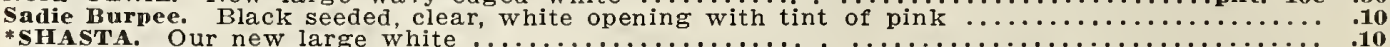

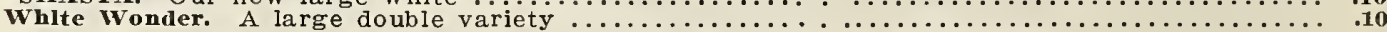

PALE YELLOW, or PRIMROSE.

* BURPEE'S PRIMROSE SPENCER. See page 44.

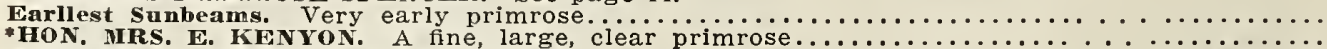

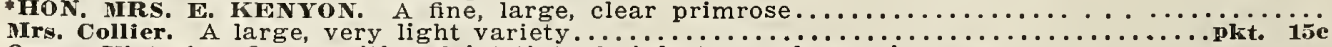

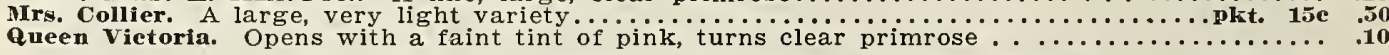

VERY LIGHT PINK, ALMOST WHITE.

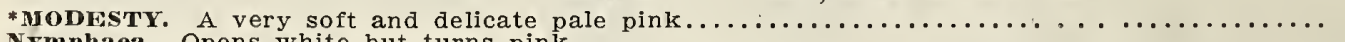

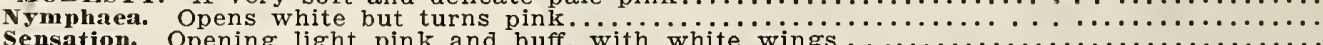

VERY LIGHT PINK AND PRIMROSE.

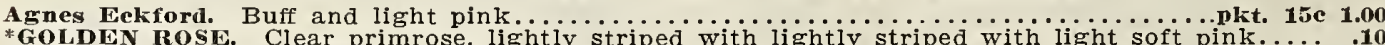

*GOLDEN ROSE. Clear primrose, lightly striped with lightly striped with light soft pink..........

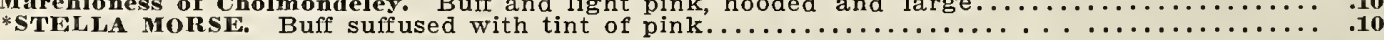

LIGHT PINK SHADES.

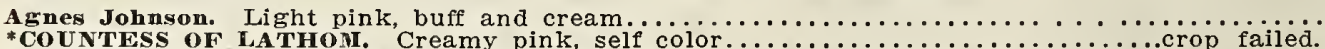

* GLADYS UNWIN. Large and wavy; a light delicate pink, a iitile deeper at the edges........

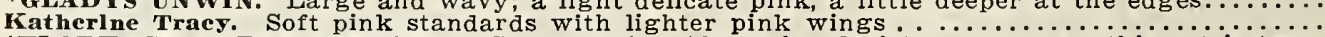

FLorENCE Morse SPENCER. See page 1. Also colored picture on cover; this cut is twothirds natural size.

Mrs. A. Watkins. Pink shading, light pink wavy......................... 10e .50

- PRIMA DONNA. The most popular and satisfactory of all the light pink varieties. A clear,

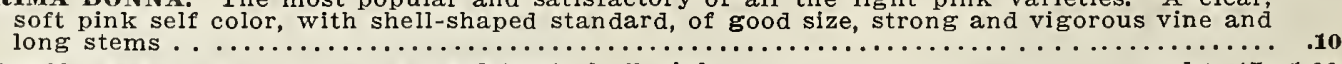

*QUEEN OF SPAIN. (The newest Eekford), buff pink $\ldots \ldots \ldots \ldots \ldots \ldots \ldots \ldots \ldots \ldots$ pkt. 15e 1.00

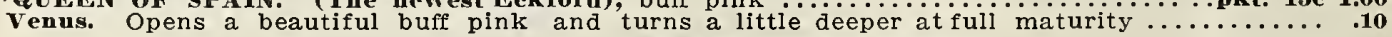
DEEPER PINK SHaDes.

* COUNTESS SPENCER. The giant flowered type with wavy edges $\ldots \ldots \ldots \ldots \ldots$ per pkt. 10e .25

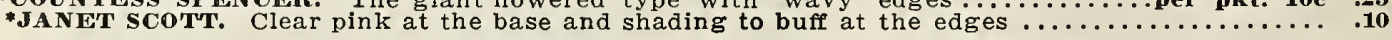
ROSE AND VERY LIGHT PINK SHADES.

Apple Blossom. Crimson-pink, shading lighter; wings white, tinted pink $\ldots \ldots \ldots \ldots \ldots \ldots \ldots$

* EARLIEST OF ALL, or EXTRA EARLY BLANCHE FERRY. The earliest variety grown.
Comes into bloom in eight or ten weeks after sowing the seed. Bright rose standard with

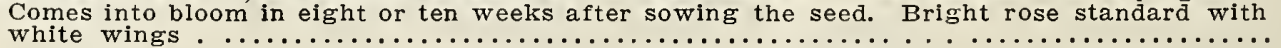

ROSE AND PINK SHADES.

*JEANNIE GORDON. Bright rose standard, showing veins of deeper rose; wings, primrose

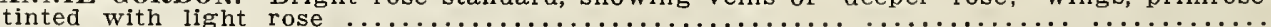

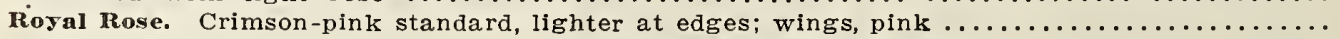
LIGHT PINK SHADED.

-DAINTY. Clear white, shaded lightly with blush pink and having distinct edgings of bright

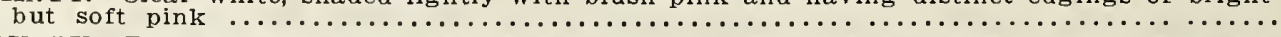

* LoVELY. Both standard and wings have a blotch of deep pink at the base, which shades a

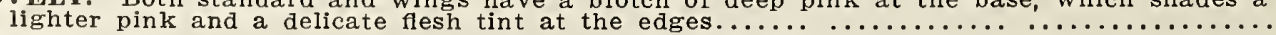

Hon. F. Bouverie. Deep pink shading, light pink, buff ground . . . . . . . . . . . . . . . ORANGE PINK SHADES.

*AURora. White, with stripes and flakes of orange-pink $\ldots \ldots \ldots \ldots \ldots \ldots \ldots \ldots \ldots \ldots$

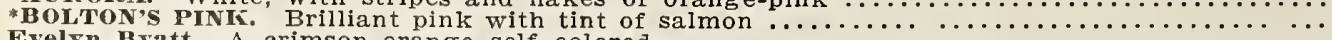

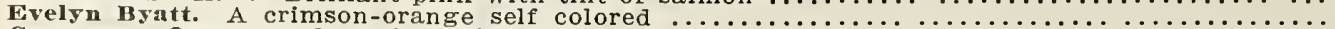

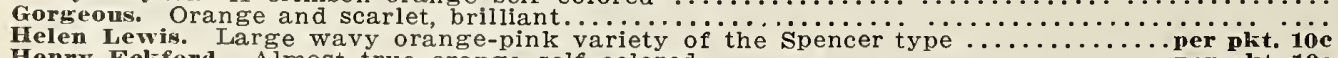

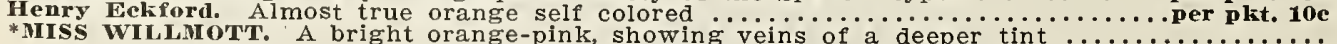
*MISS WILLMOTT. A bright orange-pink, showing veins of a deep
MRIGHT RED SHADES.

Ameriea. White, with stripes and flakes of brilliant red. The brightest striped variety ......

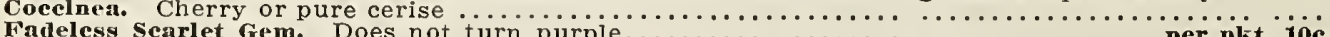

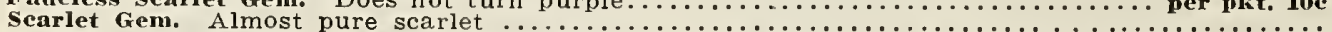
*INING EDWARD VII. (Improved Flrefly). The new red which is taking precedence over all

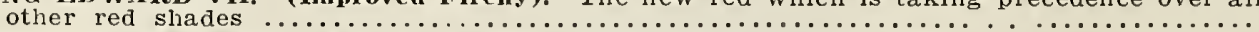

Queen Alexandra (Improved Searlet Gem). Almost a true scarlet, new ..........per pkt. 10c

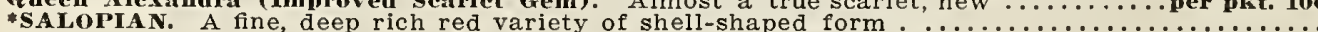
ROSE CRIMSON SHADES.

Earl Cromer. Claret magenta, a new shade ...... 15e 1.00

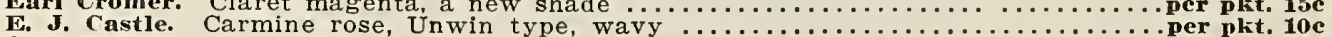

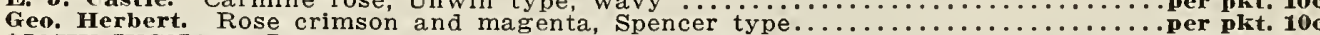

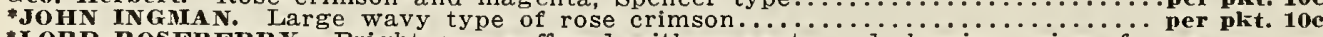

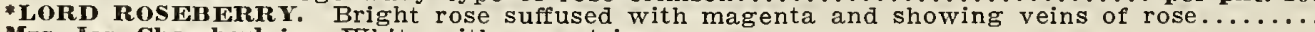

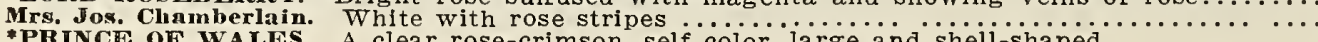


LAVENDER, MAUVE, AND PURPLE SHADES.

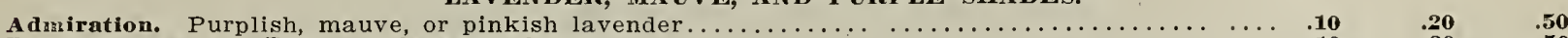

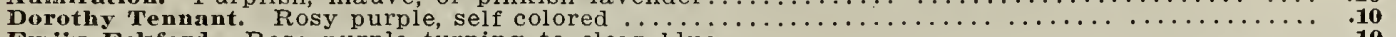

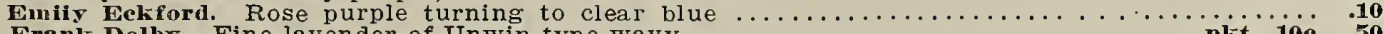

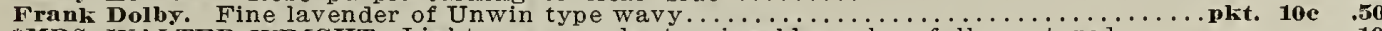

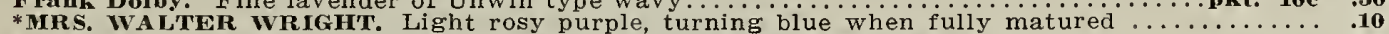

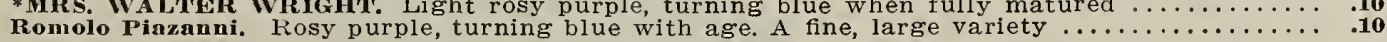
LAVENDER SHADES.

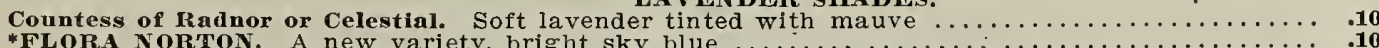

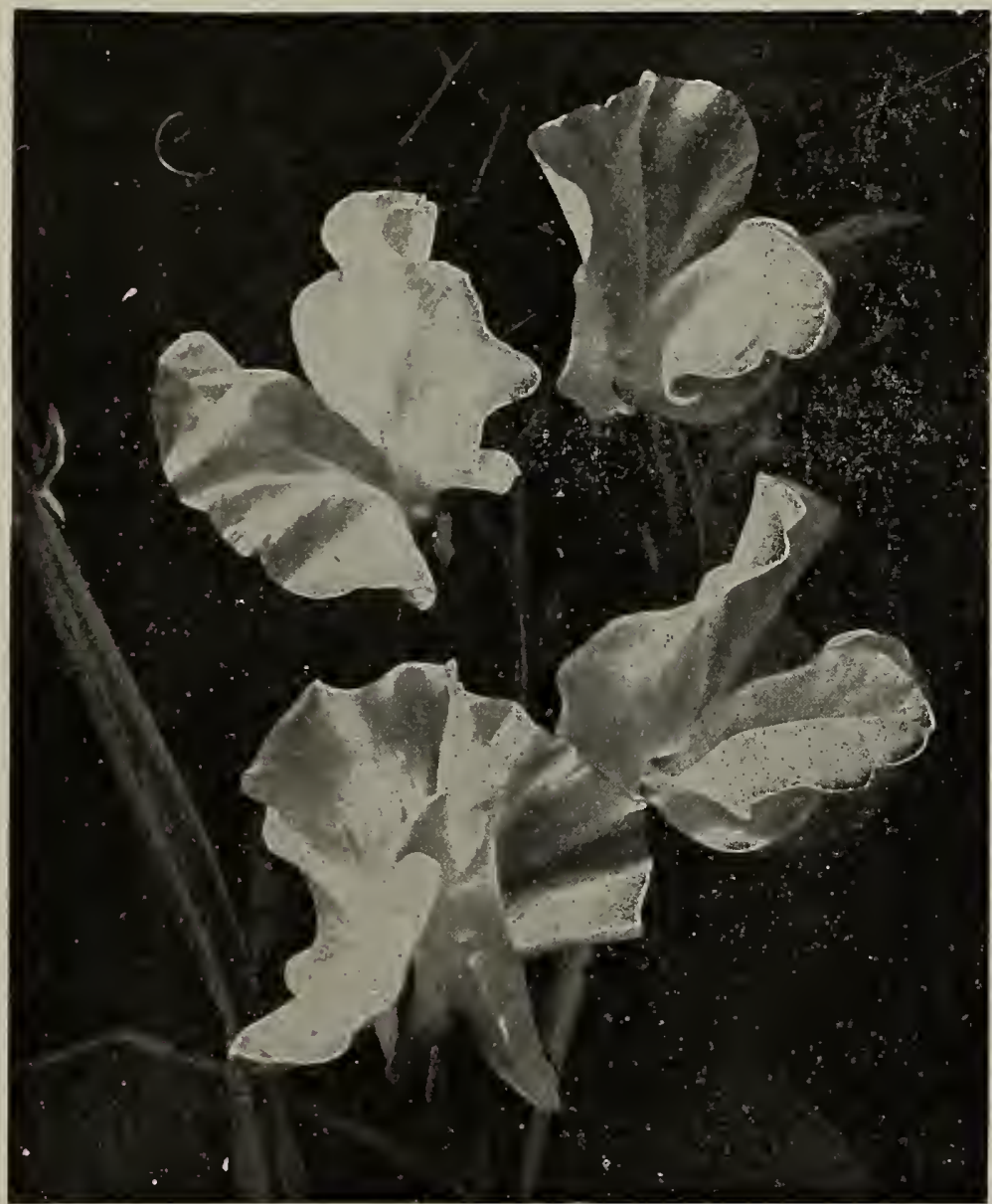

The New Giant, Wavy-Petaled Sweet Pea

Known as the Countess Spencer Type.

Can now be had in a number of new shades and colors, which we offer under the name of Morse's superb Mixture, at 25c per packet.

*HELEN PIERCE. Our o w $n$ introduction. Awarded first class certificate by National Sweet Pea Society of England. Bright blue mottled on white.

........... pkt. 10

LADY GRISEL HAMILTON. Soft lavender

* tinted with mauve SON, JR. A clear

$\begin{array}{lllll} & & \\ & .25 & .60\end{array}$

LAVENDER AND MAUVE SHADED, PICO'TEE OR EDGED.

Lottie Eckford. White, shaded with lilac, with a deeper border at the edges ........ with blue edge...... *PHEN OMENAL. Blue and lavender shaded on white; called the orchid flowering type

BLUE AND PURPLE SHADES.

Captain of the Blues. Purple and blue hooded form ..................

CONTES OF CADoGAN. Purple standards with clear blue David $R$. 'Wiliami..... Purple standard, blue wings $\ldots$ ivestrivi STER. Almost a clear purple.$\ldots \ldots$.......

senator. Pure white striped and flaked with maroon and vio let

$\begin{array}{rrr}.10 & .20 & .50 \\ .10 & .20 & .50\end{array}$

DEEP MAROON SHADES.

Black Michael. Deep wine color or light maroon .......... maroon self color...

o the 11 o. (Improved Black Knight). The best of the dark varieties, being very large and of the finest type. It is a deep maroon and particularly of rich velvet effect. $\mathbf{. 1 0} \quad \mathbf{. 2 0} \quad \mathbf{. 5 0}$

\section{DARIK MAROON AND VIOLET SHADES.}

Horace J. Wright A violet and maroon ....

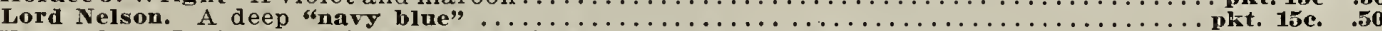

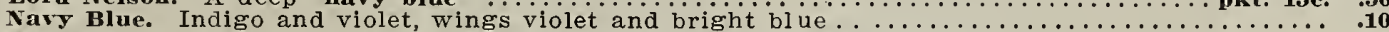

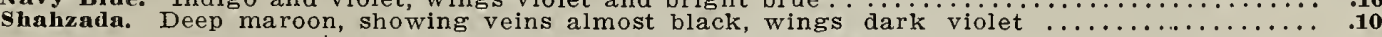
MIXTURES.

Best Large Flowering Mixture. This is the best mixture that can be made from existing varieties. The colors are well proportioned, and the amount of each is determined by a wellstudied and carefully arranged formula, which has been tried and corrected for many years.

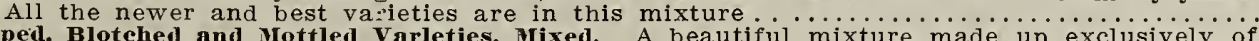

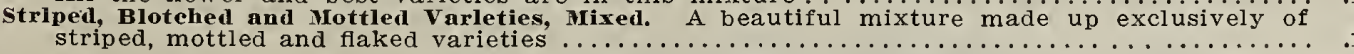

\section{CUPID SWEET PEAS}

These are low-growing or dwarf sweet peas, about one foot high and spreading to about two feet in diameter. The foliage is dark green and the stems are short, usually from three to six inches long. The blossoms, however, are larger than those of the tall varieties.

They are recommended for a border, especially along a drive or walk, and while the early buds drop off, the whole plant finally comes into bloom nicely, and is a perfect mat of bright flowers. While Cupids exist in ali the colors and shades found in the tall varieties, we have listed onl

The descriptions are the same as those of the tall varleties.

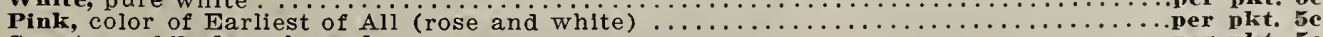

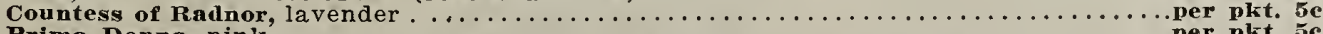

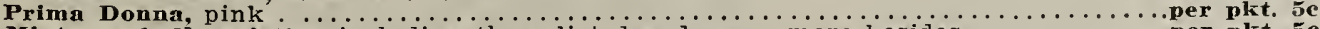
Mixture of all varieties, including those listed and many more besides............per pkt. 5e

$\begin{array}{rrr}.15 & .40 & \$ 1.00 \\ .15 & .40 & 1.00 \\ .15 & .40 & 1.00 \\ .15 & .40 & 1.00 \\ .10 & .25 & .75\end{array}$




\section{SPECIAL COLLECTIONS OF SWEET PEAS}

Our "Incomparable" 25e Collection of sweet Peas. This package contains one packet each of the following seven varieties:

King Edward VII, bright red.

Dorothy Eckford, large white.

Prima Donna, fine pink.

this

Miss Willmott, orange-pink.

Hon. Mrs. E. Kenyon, sofe primrose.

Countess Spencer, new giant pink. $10 \mathrm{c}$

Lady Grisel Hamilton, beautiful lavender.

Our "Excellent" 50c Collectlon of Sweet Peas. This package contains one packet each of the following twelve varieties:

Countess of Spencer, mammoth pink. 10c. Helen Pierce, blue mottled white. 10c.

Queen Alexandra, new brilliant scarlet. 10c. Hon. Mrs. E. Kenyon, soft primrose.

Dorothy Tekford, large white.

Lady Grisel Hamilton, soft lavender.

Miss Willmott, large orange-pink.

King Edward VII, giant bright red.

Hon. Mrs. E. Kenyon, soft primrose.

Othello, deep maroon.

Navy Blue, violet and blue.

twenty-five varieties- the newest and best- and one packet of Morse's Superb Mixture, 25c.

King Edward VII, bright red.

Dorothy Eckford, shell-shaped white.

Countess Spencer, mammoth pink. 10c.

Lady Grisel Hamilton. soft lavender.

Miss Willmott, bright orange-pink.

Hon. Mrs. E. Kenyon, large primrose.

Phenomenal, giant picotee, edged blue. 10c.

Helen Pierce, blue mottled on white. ioc.

Aurola, orange-pink striped on white.

Queen Alexandra, the new scarlet. 10c.

Helen Lewis, giant orange and salmon. $10 \mathrm{c}$.

Shasta, fine large white.

Romolo Piazanni, lilac blue.

Janet Scott, buff and brilliant pink.

othello, deep maroon.

Navy Blue, violet and blue.

Lottie Eckford, white, edged with blue.

Earliest of All, the first to bloom, pink and white.

Stella Morse, buff and blush pink.
Mrs. George Higginson, Jr., azure blue.

Mrs. George Higginson, Jr., azure blue. Countess Spencer type, not yet offered separately. 25c. Lovely, soft pink with deep throat.

Golden Rose, primrose with soft pink stripes.

Apple Blossom, pink and white.

Lord Roseberry, bright magenta rose.

XER ANTHEMUM (Everlasting Flower). A hardy annual, about one foot high, and bearing white, purple, or yellow blossoms. The leaves are hairy or covered with a silvery down. A very pretty, straw-like, ever-
lasting flower. Double Mixed.
Pkt. 5c

ZINNIA. A half hardy annual, growing from one to two feet high. Blossoms are very double, and while the stems are stiff, they make an excellent bouquet flower. The colors are in great variety and very bright. Probably no flower has such an assortment of shades, tints, and colors, and no bedding plant is more effective for a brilliant show. Sow in boxes early and transplant.

Curled and crested. A fine mixture of colors. The petals are curled and the flowers large and attractive.
Mixed. Mixed. Red, Magenta, White, Black Purple, Dark Crimson. Pkt. ioc

Double Llllput, A dwarf plant, one foot high, bearing rather small, very double flowers. Mixed. Pkt. 5e Grandifora Robusta. The largest and finest variety in existence. The blossoms are globe-shaped, very large, and in numerous colors. Mixed. Pkt. 10e Pompon Mixed. A fine mixture of globe-shaped Powers.
flow. Je Elezans. Tall, double. Mixed. Pkt. 5e Striped, or Zebra. Mixed.

\section{Summer Flowering Bulbs}

GLADIOLUS. These fine summer and fall flowering bulbs produce blooms which embrace every shade of color, and are marvels of beauty. Great improvements have been made in this flower in recent years. They are of the easiest culture and bloom the first year. As soon as the ground is warm and dry make plantings every is wanted. Take up bulbs in the fall.

Grof's Hybril Seedlings. Mixed. First size bulbs. A fine assortment of brilliant colors and gorgeous markings. 50 per dozen; $\$ 3.00$ per 100

Lemoine's Extra IFine Mixture. One of the very best strains, in splendid shades and colors.

slle per dozen; $\$ 3.50$ per 100

Fine Mixed. All colors. Mixed. 106 per dozen; $\$ 2.50$ per 100

Extrat White and very light shades. 50e per dozen; $\$ 3.50$ per 100

Fine Pink and Irose shades.

soce per dozen; \$3.50 per 100

Brilliant Searlet and Red shades. Jike per dozen; \$3.50 per 100

Extra Orange and Yellow shades.

$\$ 1.00$ per dozen: $\$ 7.00$ per 100

Striped and Variegated. 50e per dozen; \$3.50 per 100

GLADIOLUS. THE CHILDSI TYPE. Mixed. This type has mammoth petals, which are soft and wavy on the edges. It comes in light and pleasing tints as well bright colors.

TUBEROSES. One of the most delightfully fragrant and beautiful of the summer-flowering bulbs. By skillful management a succession of flowers may be obtained all the year round. For early flowers they can be started in February or March in the greenhouse or hotbed: and for a succession they can be planted at intervals as late as August. For flowering in the open border plant about the middle of May.

Excelsior Double Pearl. Extra large bulbs. 3 for 15e; 50c per dozen; $\$ 3.00$ per 100 . If wanted by mail, add loc per dozen extra.

THE YGLLOW CALLA LILY (Calla Ellottiana) is the only true yellow flowered calla in existence, and on account of its marvelous beauty has created a sensation wherever exhibited. It is a summer flowering variety, with the same habit of growth as the ing variety, with the saite Calla, with flowers of the same size and shape, but of a rich, clear, golden same size and shape, but of a rich, clear, golden
yellow. The foliage is dark green, with a number of white spots, which greatly add to the beauty of the plant-so much so that when not in flower the plant at once arrests the attention and is ever an object of enthusiastic admiration.

Fine large roots, 50e each; $\$ 5.00$ per dozen

\section{Three Splendid Japanese Lillies}

The bulbs are ready for dellvery in January and Februars, but not later.

Always very popular; either grown in pots or planted in the garden. The sorts offered below can be planted during the spring months and give excellent results during the summer. No garden is complete without a few of these charming flowers.

AURATUM. The grandest of all hardy Lilies, with large, graceful flowers of a delicate ivory white color, thickly studded with chocolate crimson spots, and a bright golden band through the center of each petal. 15e-25e ench; $\$ 1.50-\$ 2.50$ per dozen, according to slze of bulb.
SPECIOSUM ALBUM. Beautiful pure white flowers of large size. One of the handsomest and easiest grown Lilies we have.
20e each; $\$ 2.00$ per dozen

SPECIOSUM RUBRUM. White, shaded rose and spotted deep red. One of the most beautiful. Is hardy and can be grown easily out of doors. Very fine for cut
flowers.
15e each; \$1.50 per dozen 


\section{Tree and Plant Department}

"See to it that these trees are preserved. You can never replace them. Preserve and keep what nature has done."

-PREsident ROOSEVELT, at Big Trees, Feiton, California, May, 1903.

SACRAMENTO, April 19.-An appeal from President Roosevelt to the school children of the state for the observance of Arbor Day has been transmitted to State Superintendent of Public Schools Hyatt. The President says:

"We ought to celebrate this day thoughtfully, for within our life the nation's need of trees will become assured. In your full manhood and womanhood you will want what nature so bountifully supplies, and man so thoughtlessly destroys, and because of that you will reproach us, not for what we have used, but for what we have wasted. A country without trees is almost as hopeless as a people without children. The value of forestry therefore should be taught in the public schools."

OUR NURSERIES and GREENHOUSES are situated on GLEN AVENUE, off Piedmont Avenue, OAKLAND, CAL. Visitors from San Francisco can reach there by taking the new Key Route Ferry (foot of Market Street) to PIEDMONT STATION; those from Oakland, by taking the Piedmont-Avenue cars on Broadway to Glen Avenue. NURSERY TELEPHONE, PIEDMONT 30.

INTENDING PURCHASERS will do well to view our stock, as it is large, varied, and free from all sorts of scale and insect pests. Visitors are always welcome, whether they buy or not.

Customers will please remember that when our busy season commences we are rushed with orders, and it may be a day or two before their orders receive attention; but they may rest assured that there will be no unnecessary delay in shipping. Prices quoted herein are f. o. b. cars, Oakland, and cancel all previous quotations.

PACKING. Sufficient money should be added to remittance to cover cost of boxing, etc. Say 10 per cent of purchase.

GUARANTEE. We do not guarantee stock to live, nor will we replace free of cost that which dies or fails to grow; nor can we, in view of the various incidents that the stock is subject to, as the success or failure depends largely upon climatic conditions, manner of planting, after care, etc. We do guarantee, however, that our stock will be in a good, live and healthy condition upon departure from our nurseries.

CERTIFICATE OF INSPECTION will be furnished with each shipment, when desired.

SUBSTITUTION. Where particular varieties are ordered, and particular ages and sizes of trees, kinds of stock, etc., it should be stated whether and to what extent substitution will be allowed in case the order cannot be filled to the letter. Where no instructions in this respect accompany the order, we shaj1 feel at liberty to substitute other varieties as nearly similar as possible. If the selection of varieties is left entirely to us, we shall endeavor to send only such sorts as are acknowledged to give general satisfaction.

AS USUAL, 5 will be furnished at 10 rates; 50 at 100 rates; 500 at 1,000 rates.

\section{ABBREVIATIONS USED IN THE DESCRIPTION OF ROSES.}

\section{T. for Teas}

H. P. for Hybrid Perpetuals.
H. T. for Hybrid Teas.

N. for Noisette, or Champney.
P. for Polyantha, or Baby Roses.

B. for Bourbon. second page of cover.

\section{Grand New Rose-Mildred Grant}

Introduced by Dickson \& Sons, Newtonards, Ireland, and described as follows: "Ivory white, with a beautiful flush of pale peach, bordering the petals; high pointed center, with unusually large and massive petals, opening to perfectly formed flowers of enormous size and substance; a very fine variety. Awarded the Gold Medal of the English National Rose Society. This triumph alone brands it a variety of the greatest merit. Price of Strong, field grown, two-year-old plants, 50c each.

\section{Newer Roses}

Customers selecting their own roses are respectfully requested to add to their orders a few supplementary sorts, lest by previous orders the stock of any particular variety should be exhausted; this being especially necessary late in the season.

We are pleased to be able to offer in the newer roses, seven grand climbers, viz:

CLIMBING CAROLINE TESTOUT. In this beautiful new introduction we have an exact counterpart in color and shape of that old favorite bush rose, Caroline Testout. To those who may be unfamiliar with that variety, we would say that the color is a beautiful, glistening pink; the blooms are large and produced most freely for a long period; the growth is rapid, and it very quickly assumes large proportions; so that those wishing a desirable, free, quick. growing pink rose can make no mistake in ordering the Climbing Caroline Testout. Price of strong twosear-old plauts, $35 \mathrm{c}$ each or 3 for $\$ 1.00$.

CLINHING BELLE SIEBRECHT. It is with real pleasure that we introduce this lovely new climbing rose. It is identical with the older bush form; color a most rare shade of pink; the buds are long and pointed; wonderfully profuse in bloom. Priee of strong twoyear-old plants, 35e each or 3 for $\$ 1.00$. 


\section{NEWER ROSES-Continued}

CLIMBING BRIDESMAID. We have a climbing sort of the well-known favorite Bridesmaid to offer, which should be good news to those who are looking for sterling new introductions. The color is a rich shade of velvety pink; the buds are exquisite and the full blown roses equally so, being large and full; the stems are long and stiff, thus making it a valuable rose for cutting purposes. The plant is a strong climber. Price of strong field-grown plants, 35e each, or 3 for $\$ 1.00$.

CLIMEING CECILE BRUNER. It will no doubt come as a surprise, a pleasant surprise, to the lover of the rose, to learn that there is at last introduced a climbing sort of this ever popular "Baby" Rose. In known; the blooms come in clusters and bloom for a long period; color, beautiful salmon-pink, with a much deeper shade of same color in center. Habit of growth very strong and vigorous. Price of strong field-grown plants, 35e each, or 3 for $\$ 1.00$.

CLIMBIG SOUVENIR DE MALMAISON. The bush form of this variety is one of the best of its kind, and in this new climbing sort we have an exact counterpart in color and shape. A beautiful shade of flesh color, deeper towards the center of the petals. Price of strong field-grown plants, 35e each, or 3 for $\$ 1.00$.

ClIMBNG PAPA GONTIElt. The bush form of this old favorite red Tea Rose is known to all, so that a climbing sort of it will be a welcome acquisition to the list of roses. The buds are long and pointed and of deep-red color. It is a free and continuous bloomer, like its parent. Habit of growth, strong and free. Price of two-year-old plants, 50c each, or 3 for $\$ 1.25$.

GRUSS AN TEPLETY CLIMBING HERMOSA. There has always been a scarcity of good, dark, climbing everblooming, red roses, so the rose-loving public will be pleased to learn that we have one to offer in Gruss an Tepletz. The color is velvety scarlet; and it is continually in bloom. It is of fast growth and very $35 \mathrm{c}$ each, or 3 for $\$ 1.00$.

MARCHIONESS OF LONDONDERRY. Flowers of great size, measuring seven inches across, perfectly formed, and carried on stout stems Color, ivory white petals of great substance, shell-shaped and reflexed free flowering; highly perfumed; growth vigorous and foliage very handsome. Awarded the gold medal of the National Rose Society of England. A decided acquisition to the list of hardy white roses. Price of strong field-grown plants, $35 \mathrm{e}$ each, or 3 for $\$ 1.00$.

ROSE OF KILLARNEY. This grand new rose was raised by Dickson \& Co., of Belfast, Ireland, who have sent out so many sterling novelties in the rose line. The color is a glistening, soft, silvery pink, the petals being waxy in appearance; the buds are long and pointed, slightly reflexed at the ends; the rose when full blown being fairly double. In continuity of bloom the Rose of Killarney is unsurpassed. 50c each, or 3 for $\$ 1.25$.

\section{ROSES - CHOICE ASSORTIENT}

In this list will be found nothing but the very best sorts.

These roses that we offer are thrifty, well-developed two-year-old plants, and are shipped in a dormant condition from about December 15th to about April 1st.

PRICE. 25c each; $\$ 2.50$ per dozen. Extra Selected large plants, 35c each; $\$ 3.50$ per dozen.

We will not supply less than six of a kind at dozen rates; if one of a sort is ordered single rates will be charged.

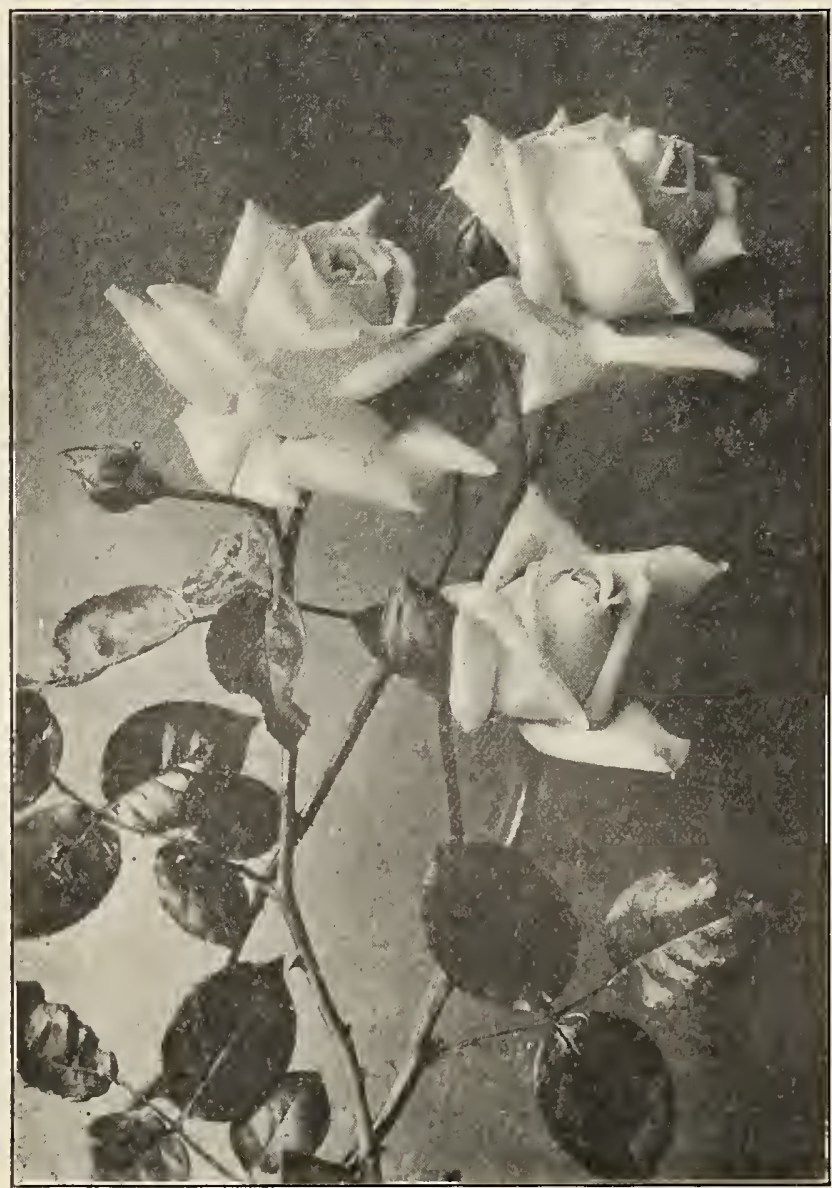

Kalserin Augusta Victoria
ABEL CARRIERE. (H. P.) Velvety crimson with fiery center; of fine form and sweetly perfumed.

AGRIPPINA. (B.) Rich velvety crimson; flowers come in clusters; very floriferous. This is the sort that is so much used for hedges.

ALFFED COLOMB. ( $H$. P.) Brilliant carmine crimson: very large, full and of fine globular form; extremely fragrant; a superb sort.

AMETICAN BEAUTY. (H. P.) Large, globular, deep pink, shaded carmine, deliclous odor; a fine variety for forcing.

A MERICAN BELLE. ( $H$, P.) A choice pink variety; full and double and sweetly scented.

A IAZONE. (T.) Yellow, reverse of petals veined with rose; long. well formed buds.

ANNA OLIVEIR. Creamy blush shaded with deep car mine, tinged and edged with silvery rose; very large, full and double; an excellent sort

ANNA DE DIESBACH. (H. P.) Brilliant crimson, shaded with maroon. Long-pointed buds and large compact flowers.

AUGUS'TINE GUINOISSEAU (White La France). ( $H$. T.) This beautiful variety with flowers of pure white shading to a center of light rose, is a great favorite on account of its great freedom of bloom, fragrance, and large flowers, A vigorous grower, producing a great number of buds and flowers.

AVocat DUVIVIER. ( $H$. P.) Crimson, large, full, well formed and fragrant; a fine rose.

BANKSIA, White and Yellow. These are the well-known thornless climbing roses, The flotvers are small, but bloom in great profusion in spring and early summer.

BARDOU JOH. The color of this beautiful rose is rich velvety crimson, with yellow stamens. A grand climber.

BA RON DE BONSTETTEN, (H, P.) Splendid large flowers; very double and full; color, a rich, dark red, passing to a velvety maroon. Highly scented and very beautiful.

BEAUTY OF GLAZENIVOOD. Variously known as San Raficl Rose, Hester Rose, Fortune's Yellow, and erroneously named Grold of ophir in Southern California. (Bankia). A combination of copper carfornia. (Bnnksia). A combination of copper, carmine, and salmon-yellow. A strong, fast climber. time and which is admired wherever seen.

BELLE SIEHRECHT (H. T.) A superb pink rose of recent introduction. The buds are long and pointed and when half-blown the petals reflex in a graceful manner. The flowers have great substance and the petals are of heavy texture. 
BEAUTE INCONSTANT. (T.) Flowers are pink, blotched white; a constant and profuse bloomer. Much admired.

BLA CK PRINCE. (H. P.) Crimson, shaded with purple; medium size. A good dark rose.

BON SILENE. (T.) Buds of beautiful form; an unusually free bloomer; color, deep rose-shaded carmine.

BRIDE. An ever-blooming pure white Tea Rose, of large size and most perfect form. The buds are pointed, and the ends of the petals are slightly recurved. It is a very free-blooming variety, and has a most deis a very free-blooming variety, and has a most
licious tea fragrance. One of the best white roses.

BRIDESMAID. In this exquisite Tea Rose we have an improved Catherine Mermet, from which it is a sport. improved Catherine Mermet, from which it is a sport. Mermet, on account of its exquisite shape, large, colid, firm buds, with long stiff stems, has long been maid at all seasons is a clear, delicate pink, in all respects a counterpart of Mermet, with large handsome; pointed buds on long stiff stems.

CAROLINE TESTOUT. See second page of cover for description.

CAMoEns. (H. T.) Bright pink, yellow center; finely pointed buds; vigorous grower and good bloomer.

CAPTAIN CHRISTY. (H. P.) Of delicate flesh color, rosy center. Flowers extra large, double, full, and sweetly scented.

CAPTAIN HAYWARD. (H. P.) Bright carmine crimson; very large; free bloomer and a vigorous grower.

CHARLES GATER. (H. P.) Deep brownish crimson, distinct in color; flowers, large and very globular.

CECILE BRUNER. (P.) A charming "Baby" variety of sweet, delicate fragrance. Color, salmon-pink, with deep salmon center.

CHEROIKEE, single. One of the finest pillar roses in cultivation; large, clear, white, single flowers, full of bright yellow stamens, which give it a most unique appearance; foliage, dark, rich green. A most vigorous grower.

CHER OKEE, Double White. A rampant climber

CHESHUNT HYBRID. ( $H$. T.) Cherry carmine; large and full flowers of strong habit; constantly in bloom; good pillar rose.

CLAIRE CARNO'T. (N.) Color, fine coppery rose, shaded with amber at base of petals; bordered with white and rosy carmine.

CLIMBING CAPTA IN CHRISTY. (H. P.) Those who know the old bush form of Captain Christy will be pleased to learn that we now have a climbing variety of this old favorite; delicate flesh color.

CLIMBING DEVONIENSIS. (T.) Large, creamy-white, shell-like petals of great substance; large, full and very fragrant.

CLIMBING KAISERIN AUGUSTA VICTORIA. (T.) Buds long and pointed; pure white, of superb substance and texture; a strong and rapid grower.

CLIMBING NIPHETOS. (T.) A splendid companion to the Climbing Perle des Jardins. Color, pure white, with pale lemon center; beautiful long pointed buds; very fragrant.

CLIMBING PERLE DES JARDINS. (T.) Habit of growth is vigorous, young plants often sending up shoots six to eight feet high in one season, with rich, glossy foliage, and bright red stems. The flowers are produced in profusion and are deep canary-yellow.

CLIMAING SAFRA No. See Reve d'or.

CLIO. ( $\mathrm{H}, \mathrm{P}$.) A really grand rose; on the order of Baroness Rothschild; recommended by expert growers as the finest rose of this type; strong, vigorous grower; handsome foliage; flowers are flesh color, shaded in the center with rosy pink; large, of fine globular form; freely produced.

CLOTH OF GOLD. (N.) Deep yellow center, with sulphur-colored edges. A good climber.

CORNELIA CoOK. (T.) Beautiful creamy white; petals of strong texture; free and continuous bloomer.

COUNTESS RIZA DU PARC. (T.) Bronzed rose; flowers medium size, moderately full; highly perfumed; very vigorous; large and full.

CRIMSON RAMBLER. (P.) Of remarkably vigorous growth, making shoots from eight to ten feet high in one season: flowers of brightest crimson, and produced in great pyramidal panicles, each having thirty duced in great pyr
to forty blooms.

CHRISTINE DE NOUE. (T.) Deep purplish-red, center lake and clear purple; very large and full; sweetly perfumed.

CRESTED MOSS, Double pink.

DUCHES d'AUERSTADT. (T.) Coppery-red, blended pink; a most lovely and unique variety.

DUCHESS DE BRABANT. (T.) Soft, rosy flesh, changing to deep rose color, edged with silver. Beautiful in bud, and highly fragrant.

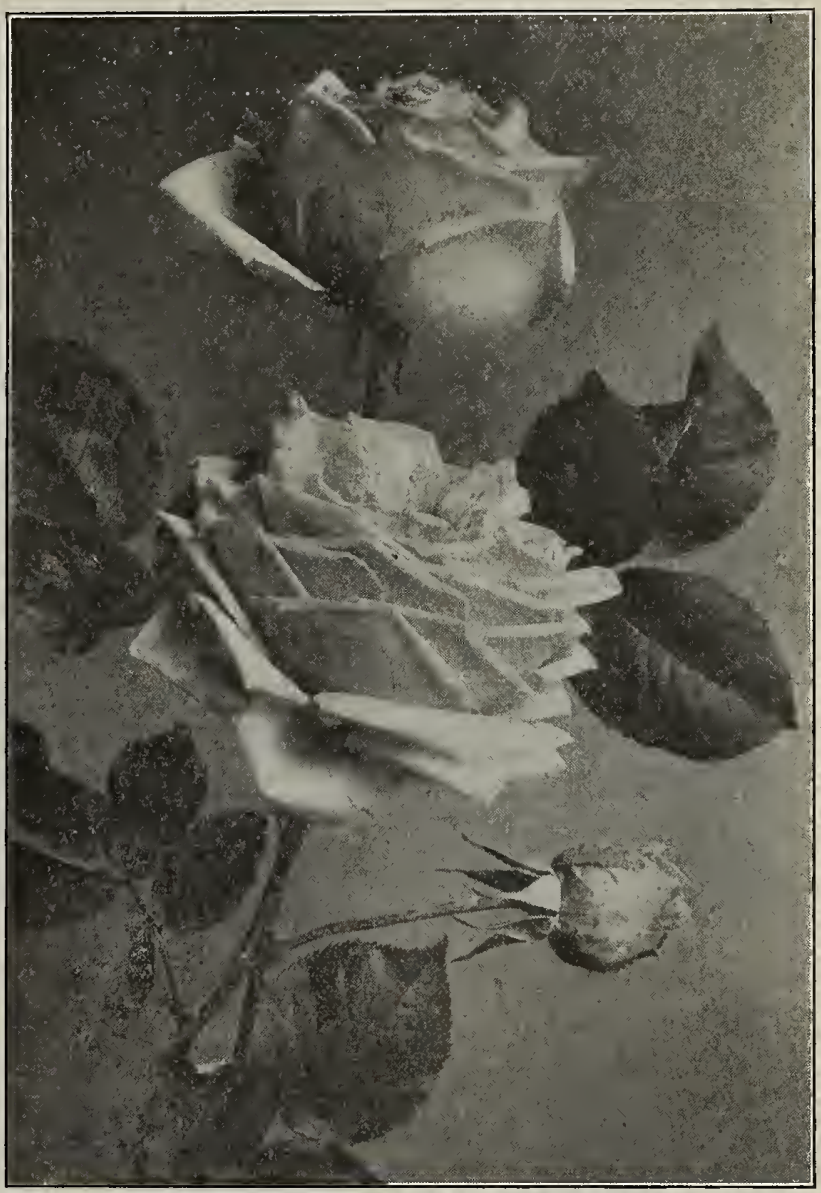

La France of ' 89

DR. GRILL. (T.) Clear buff pink, passing to a clear rose and fawn, elegantly suffused with pale canaryyellow. A most profuse and regular bloomer.

EMPEROR OF MOROCCO. (H. P.) An intensely dark rose, of velvety maroon.

EARL OF DUFFERIN. (H. P.) Rich brilliant velvety crimson, shaded with dark maroon; large, full, finely formed; delightful fragrance. A vigorous grower. formed; delightful fragrance. A vigorous grower. collection.

FRANCOIS DUBREUIL. (T.) Deep crimson; very free flowering; beautiful in bud.

FRAU KARL DRUSCHIKI. See second page of cover for description, etc.

FLORA MeIVOR (Sweet Briar). White, tinged rose.

GENERAL JACQUEMINOT. (H. P.) Rich velvety crimson, changing to scarlet crimson. A magnificent rose, beautiful in the bud or open. Is without a rival in fragrance and richness of color.

GLOIRE DE DIJON. (T.) A combination of rose, salmon and yellow; flowers very large and full. A good climber.

GLOIRE DE MARGOTTIN. (H. T.) The most beautiful of all red climbing roses. Specially adapted for planting against fences and houses. Can also be grown on a trellis. Color, a most brilliant shade of red buds large, long and pointed.

GLOIRE DE BOURG LA REINE. Vivid red, a very striking color; flowers large and double; a good bloomer.

GLORY OF Mossics. Pale rose; very large and full.

GOLDEN GATE. (T.) Canary-yellow flowers of delicate appearance; highly commendable in all respects.

GOLD OF OPHIR. (T.) Salmon yellow, shaded with bright deep rose. Climber.

HELEN KELLER. (H. P.) Brilliant rosy cerise; flowers large of most perfect form; sweetly perfumed; a vigorous strong grower. 


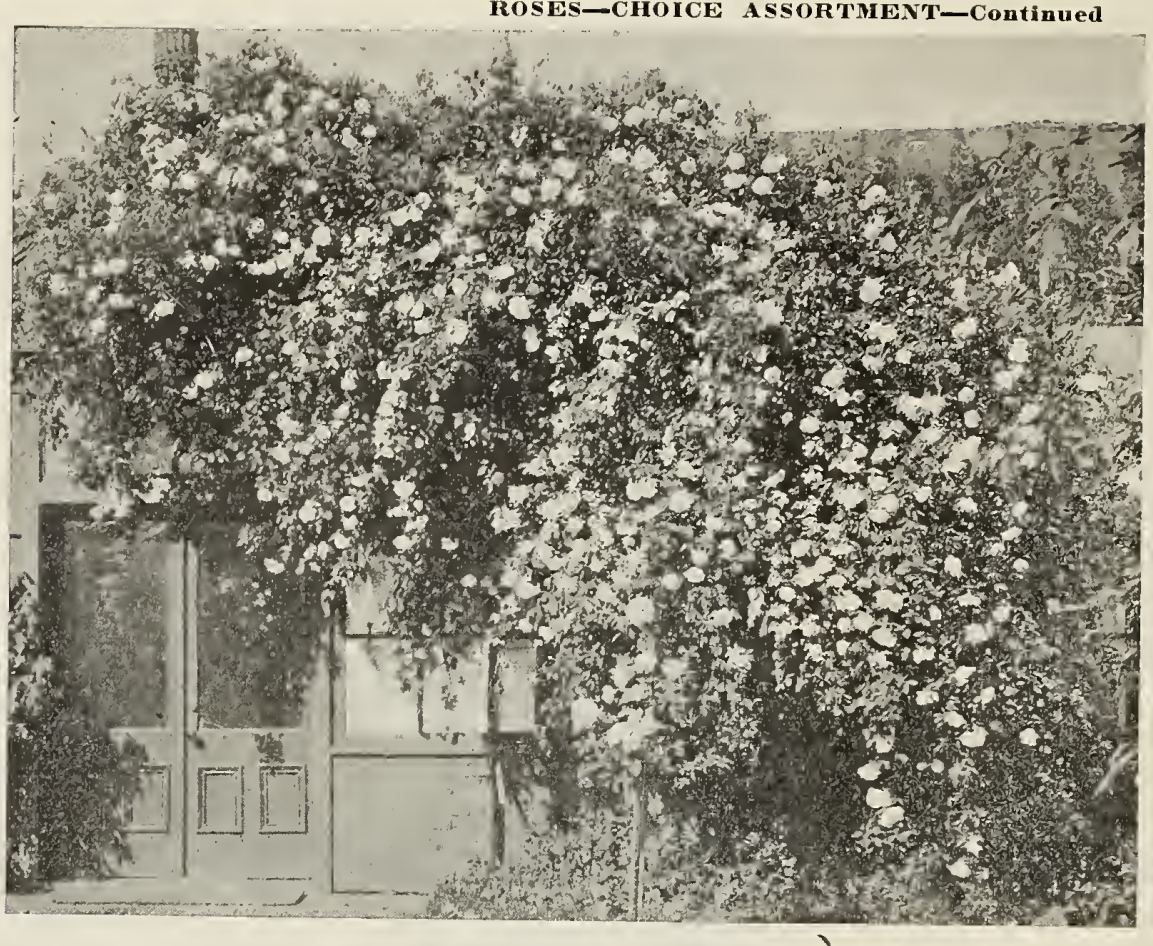

Lantarque- White Crinber Photo C. C. Morse \& Co.
MADAME LAMBARD. (T.) A grand rose; silvery and double at all times.

MADAME JOSEPH SCHWARZ (T.) A lovely Tea Rose: extra large; globular flowers, very full and delicious very full and delicwhite, elegantly tinged White, elegantly tinged low and rosy blush; an exceedingly beautiful rose, and a constant and profuse bloomer.

MADAME CLAIRE JAUBERT. (T.) Salmon-pink; the blooms come in clusters in great profusion; a desirgreat prof
able sort

MADAME SCIPION COCHET. (T.) Rose-yellow; large and double, margins of petals undulated; beautiful glossy foliage.

MADA ME EUGENE VERDIER. (H. P.) Mottled rose color; very large, full and globular.

MADAME II, MOREAU. (Tea.) A peculiar shade of coppery-yellow; reverse of petals rosy apricot; very beautiful. The buds are large and double as are also the full blown roses; a good continuous bloomer. MADAME BOUTON. (H. P.) Deep red; flowers large and full; a good rose.

NLLE C. BRENER. See Cecile Bruner.

HENRMCF SCHULTHEIS. (H. P.) Splendid large flow-
ers, very double and sweet: color, delicate pinkish ers, very double and sweet: color, delicat
rose, wax-like substance; very beautiful.

ISABGLLA SPRUNT. (T.) Beautiful canary-yellow; buds long and pointed.

MAGN CHARTA. (H. P.) Bright, clear pink, flushed with violet crimson; flowers large, fine form, very double and full.

MAMAN COCHET PINIK. (T.) Deep pink; buds long and pointed; of great substance; a continuous bloomer.

JEAN BART. (H. P.) Dark velvety maroon; fine, large flowcr, fairly glowing with its bright, rich color: an
attractive novelty.

JEAN LIABAUD. (H. P.) Fiery crimson, shaded with black; very dark and rich: flowers large, full, and beautifully formed, and a rose of good habit.

FAISERIN IUGUSTA VICTORIA. (T.) Full flowers: magnificent in bud; stems long, and bearing large. strong canes, with handsome foliage; flowers pure white. A grand sort.

LA FRANCE. (H. T.) Delicate silvery rose, shaded with ccrise pink, often silvery pink, with pcach shading: very large, very double; of superb form.

LA FIRANCE OF' 89 . (H. T.) Long. elegant buds, approaching scarlet; of sweet fragrance; a long and continuous bloomer; very desirable in every way.

LA MAFQUE. (N.) Pure white buds, open flower tinged light canary-jellow; large and full. A grand climber.

LADY HELEN STEWART. (H. P.) Bright scarlet crimson; flowers fully roundcd out, petals largc and thick;

LADY MARY FITZWILLIAM. (H, P.) Bright, delicate flesh color, somewhat resembling Captain Christy.

LIBERTY (The New Century Meteor). (H. T.) Color, in texture, cup-shaped; of delicious crimson-scarlet, vclvety in texture, cup-shaped; of delicious fragrance; con-

L'IDEAL. ( $T$.) Coppery-yellow, blended pink; exouisite in every particular.

LAURETTE MESSIMI. Rose-pink, shaded yellow; very
pretty and distinct MADAME: C. GUINOISSEIU. (T.) Beautiful shade of canary-yellow; long pointed buds; vcry free.

MADAME CAROMINE TESTOUT. See Caroline Testont. MADAME DE WATTEVILIE. (T.) A lovely blended sort; white tinged bronzy yellow.

MADAME FALCOT. (T.) Deep apricot, shaded buff. MADA ME GABRIEL LUIZET. (H. T.) Beautiful shade of coral pink; sweetly fragrant; strong grower.

MADAME HOSTE. (T.) Canary-yellow; buds long and pointed when full blown; very double; very free.
MATCHONESS OF LORNE. (H P) Deep pink; flowers full and double; of exquisite fragrance.

MARECHAT, NIEL. (N.) Beautiful deep yellow: large, full, and of globular form. A good pillar rose.

HARIE VAN IOUTTE. (T.) White, slightly tinged with yellow; a free grower and fine bloomer. Exquisite.

MAIE IAUMANN. (H. P.) Brilliant carmine crimson: large, full of exquisite color and form; very fragrant Extra fine.

MERVEILIE DE LION. (H. P.) Pure white, shaded and marked with satiny-rose: flowers very large, double, and of a beautiful cup shape. A superb variety.

7FIEOR. (H. T.) Color, rich velvety crimson, very bright and striking; the flowers are large and regular, perfectly double and wcll borne up; it is a constant and profuse bloomer and very fragrant.

MRS. JOIN LAING. Soft pink: large and of fine form, produced on strong stems; exceedingly fragrant.

MRS. R. G. SHARMAN CRAWFORD. (H. P.) Color, deep rosy pink, outcr petals shaded with pale flesh, white at base of petals; flowers large, of perfect imbricated form, and freely produced, flowering from early summer until late in autumn. Growth vigorous. Awarded gold medal of the National Rose Society of England and many first-class certificatcs. A valuable addition.

NIPIETOS. (T.) An elegant white rose. The buds are long and pointed.

OAKMONT. (H. P.) Deep bright rose color, in the way of Paul Neyron, but blooms mucl more freely, delightfully scented; continues in bloom all summer.

PAPA GONTIFR. (T.) A splendid variety, valuable both for open ground and greenhouse culture; it is a strong. vigorous grower and free bloomer; the buds are extra large, finely formed and very beautiful flowers double and full, and exceedingly sweet; color bright cherry red, passing to rich, glowing crimson, petals shaded with yellow; very striking and handsome.

PAUL NEYRON. (H. P.) Extra large and full; fine form: deep carmine color; very fragrant: free bloomer; an excellent rose. 
PAUL'S EARLY BLUSH. (H. P.) A superb rose in every respect; color, light silvery blush; large, fine, bold shape, producing its flowers among the first and continuing throughout the season.

PERLE DES JARDins. (T.) Fine straw yellow; sometimes deep canary yellow; very large and full, and the most perfect form; one of the finest roses grown; steps at once into fame as the finest dwarf yellow rose we have.

PINK Rover. (H. T.) Very pale pink, deeper in the center; large and full; exceedingly sweet; buds large and handsome; of semi-climbing habit.

PERLE D'OR (P.) Coppery gold changing to fawn and salmon; charming and very distinct and one of the prettiest of the Fairy or Baby Roses.

PRESIDENT (T.) Fresh carmine rose; extra large, very double and full; free bloomer; delicious "tea" scented.

PRINCE CAMILE DE ROHAN. (H. P.) Rich, dark, velvety crimson, changing to scarlet maroon; full double and sweet.

PRINCESS DE SAGAN. (T.) Rich velvety crimson; a good and abundant bloomer.

QUEGN OF EDGELEY, Pink Ameriean Beauty. ( $H$. P.) In color it is a light pink, resembling Madame $C$ Testout and Bridesmaid. The flowers are large and deep, cup-shaped and full, averaging five inches when full blown, and are borne on long stems. The fragrance is delicious.

RAINBOW. (T.) The color is a lovely shade of deep coral pink, beautifully striped and mottled in the most unique manner with intense glowing crimson, elegantly colored at center with rich golden amber; makes beautiful buds, and the flowers are extra large, very sweet, and of great depth and substance.

REINE MARIE HENRIETTA. An extra fine climbing variety; flowers large, full, and handsome; color, clear cherry red; a grand acquisition to climbing roses.

REINE OLGA DE IVURTEMBERG. A lovely bright red;

semi-double. A strong rampant grower.
REVE D'oR. (Climbing Safrano-N.) Deep yellow, sometimes coppery yellow or rosy buff; large, full, and sweet. A beautiful climber.
SAFRANO. (T.) Buff apricot; a constant and profuse bloomer; one of the old favorites.

SALAMANDER. (H. P.) Very bright scarlet crimson; iarge and of good habit.

SOLEIL D'OR. A grand new yellow rose. The color in bud is a rich chrome yellow tinted with coppery rose, and on expanding becomes a beautiful orangeyellow, shaded with copper and red; a very free bloomer and one of the best and most distinct roses of recent introduction.

SOUVENIR DE MALMAISON. (B.) Hardy; free blooming of beautiful, clear, flesh color, edges blush.

SOUVENIR DE PRESIDENT CARNOT. (H. T.) A continuous and free bloomer, with most delightful fragrance; extremely large, both in bud and flower, retaining its full shape even when full blown; long and pointed; color delicate rosy flesh, shaded to pink.

SOUVENIR DE WOOTTON (H. T.) One of our best red, everblooming, highly fragrant sorts. Flower is large and full; color beautiful shade of carmine crimson; strong grower.

SUNSET. (T.) Identical in every respect with Perle des Jardins, except that its color is that of rich safron and orange.

THE QUEEN. (T.) Pure glistening white; buds full and double; very free in bloom.

ULRICI BRUNER. (H. P.) This we consider one of the most satisfactory of all the Hybrids. Flowers large, full and sweet; color, bright, clear red; a profuse bloomer and hardy grower.

VISCOUNTESS FOLKESTONE. (H. T.) The flower is delicately tinted flesh, almost white, and lustrous as satin; when full-blown it is like a fine white Peony, but without stiffness; sweet-scented.

W. F. BENNETT, ( $H ., T$.) Rich red; buds long and pointed; very fragrant; flowers large, borne on good long stems.

WHITE LADY. (T.) A very showy white rose; flowers very large; a constant bloomer.

WHITE LA FIANCE. (See Augustine Guinoisseau.)

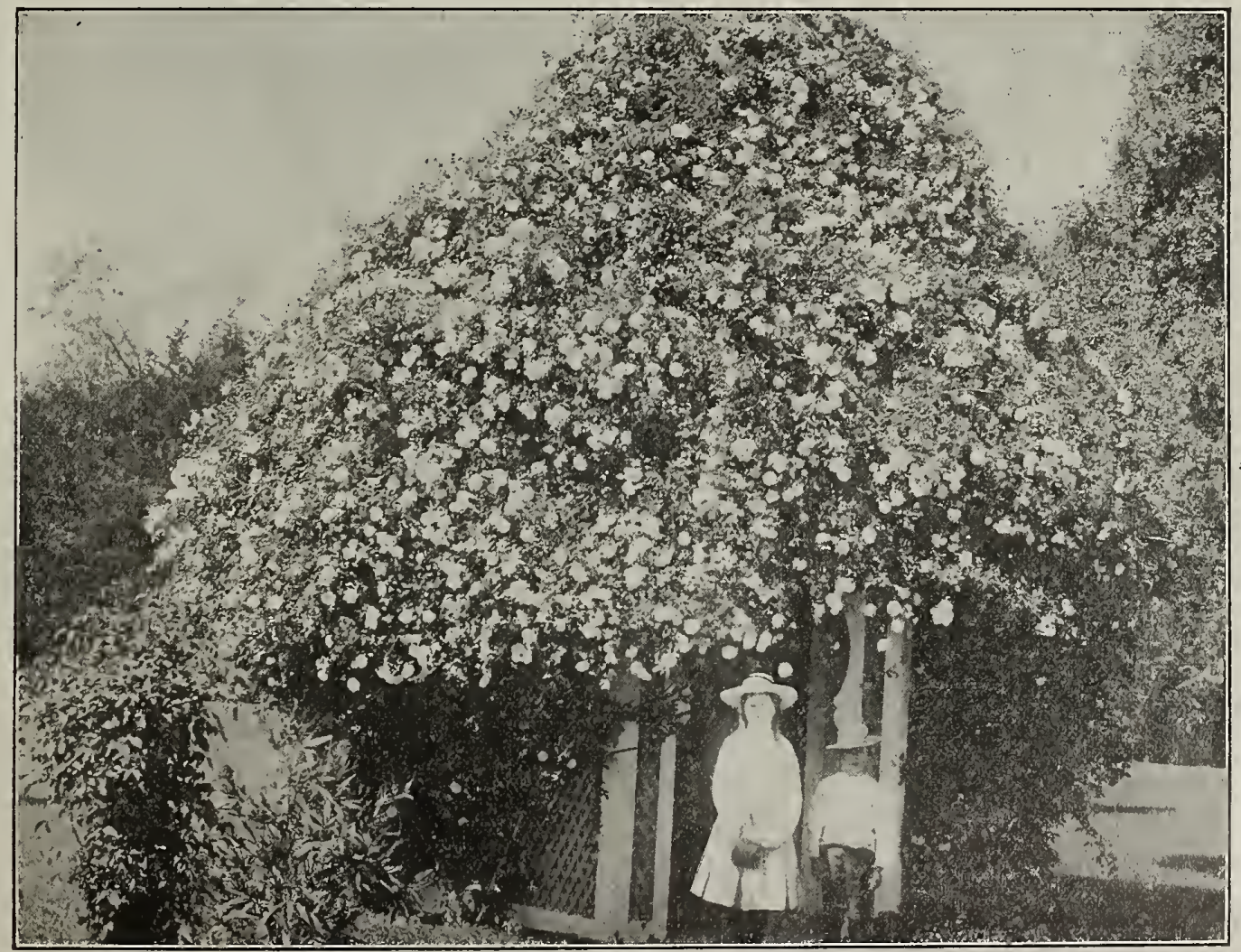


ROSES-CHOICE ASSORTHENT-Continued

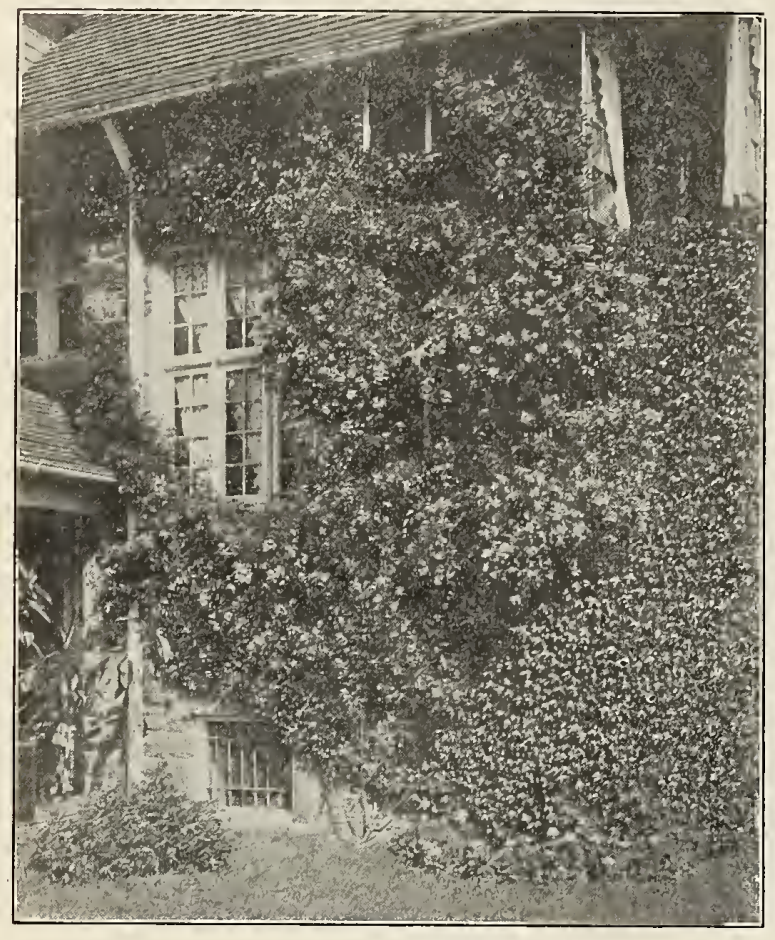

Crimson Rambler

WHITE MAMAN COCHET. (T.) This American sport of the grand French variety, Maman Cochet, is one of the best whites of recnt introduction; the buds are solid, long and pointed, faintly suffused pink on outside petals, and borne very freely; foliage glossy; plant strong, vigorous and. healthy; highly commended.

WILLIAM ALUEN RICHARDSON. (N.) Fine orange yellow, apricot center; medium size; full, very showy and distinct. A beautiful climber.

YELLOW RAMBLER. This variety will be found a grand companion to "Crimson Rambler." The flowers are borne in large clusters, very profusely; color canaryyellow.

XAVIER OLIBo. One of the darkest roses; very sweet and a free bloomer.

We can supply the following roses in Standard or tree form, that is they are budded on single stems, three to four feet from the ground. \$1.25 each. \$10 per 10.

American Beauty.

Belle Siebrecht.

Cath. Mermet.

Frau $K$. Druschki.

Gloire de Dijon.

Gloire de Dijon.
Gustav Regis.

Mad. P. Cochet.

L'Ideal.

For convenlence sake we give below a list of those Foses that ellmb:

Banksia-White and Yellow. Bardou Job.

Beauty of Glazenwood

Cherokee

Climbing Belle Siebrecht.

Climbing Bridesmaid.

Climbing Malmaison.

Climbing Cecile Bruner.

Cheshunt Hybrid.

Climbing Cap. Christy.

Climbing C. Testout.

Climbing Devoniensis.

Climbing Papa Gontier.

Climbing Niphetos.
Climbing $P$. des Jardins. Climbing Kaiserin. Cloth of Gold. Crimson Rambler. Gloire de Margottin. Gruss an Tepletz. La Marque.

Marechal Niel. Reine Marie Henrietta. R. O. de Wurtemberg. Reve d'Or.

W. A. Richardson.

Yellow Rambler. Gloire de Dijon.

Kaiserin Augusta Victoria Marie Van Houtte.

Marechal Niel.

Souv de Pres. Carnot. Souv de $\mathrm{P}$. Ulrich Bruner

\section{ROSES ARRANGED IN COLOR CLASSES.}

WIIITE. Augustine Guinoisseau, Bride, Cherokee, Cornelia Cook, Devoniensis, Gloire Lyonnaise, Kaiserin Augusta Victoria, La Marque, Madame A. Carriere, Maman Cochet, The Queen.

YELLOW. Cloth of Gold, Glorie de Dijon, Golden Gate, Isabella Sprunt, Madame C. Guinoisseau, Madame Falcot. Madame Hoste, Marechal Niel, Perle des Jardins, Reve d'Or, Safrano, Sunset, W. A. Richardson, Yellow Rambler.

BRONZE YELLOW. Beauty of Glazenwood, Claire Carnot, Dr. Grill, Gold of Ophir, L'Ideal, Soleil d'Or.

PINIK IND Rose SIMADE. American Beauty, Belle Siebrecht, Bon Silene, Bridesmaid, Caroline Testout, Duchess of Albany, Killarney, La France, Madame G. Luizet, Magna Charta, Mrs. John Laing, Mrs. J. S. Crawford, Madame Lambard, Pink Maman Cochet, Paul Neyron.

SCARILT CRIMSON AND SIIADES. Agrippina, Anna de Diesbach, Bardou Job, Chestnut, Hybrid, Crimson Rambler, General Jacqueminot, Gloire de Margottin, Liberty, Marchioness of Lorne, Meteor, Papa Gontier, Riene Marie Henriette, Reine O. de Wurtemberg, Ulrich Bruner.

VERY DARIK REDS. Baron re Bonstetten, Black Prince, Emperor of Morocco, M. P. Wilder, Prince C. de Rohan.

SALMON SHADES. Captain Christy, M'lle C. Bruner, Souvenir de President Carnot, Viscountess Folkestone.

BLENDED AND VARIEGATED SORTS. Beaute Inconstant, Countess R. du Parc, LIdeal, Madame de Watteville, Marie Van Houtte, Rainbow.

N. B.-We grow the leading sorts of roses ir pots. so that if any of our customers are unable to get their planting done during the dormant months, they can purchase potted plants than can be set out at any time, without danger of their dying. $35 \mathrm{c}$ each; $\$ 3.50$ per dozen.

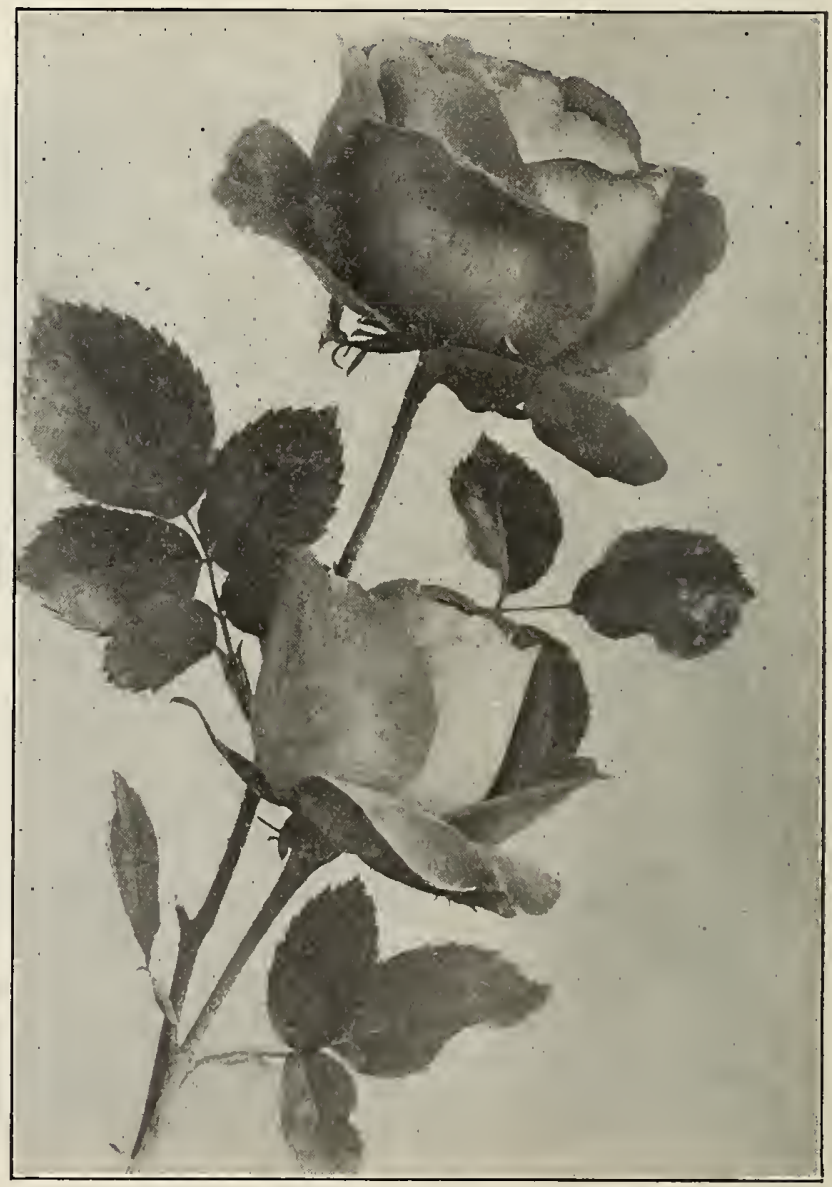

Ulrieh Bruner 


\section{Desirable Hardy Evergreen Trees and Shrubs}

\section{ABIES-SPRUCE, FIR AND HEIILOCK}

Among these will be found some of the grandest coniferous trees in existence. For reforesting they are unequaled and for home beautifying find no rivals; all of fairly rapid growth.

BALSA MUANA (Balsan Fir). A very erect, regular py ramidal tree with dark green somber foliage; grows rapidly and is very hardy, suitable for planting in cold, damp woods and swamps.

Balled, 2 to $21 / 2$ feet, $\$ 1.50$ each

BLUE (Glaucous Spruce). A small and beautiful variety of rather loose spreading habit, with bluish green foliage; very hardy and valuable. $11 / 2$ feet, 5 cench.

CoERULEA HUdsonir. Deep sea-green foliage. Most desirable. $\quad$ Balled, $1 \frac{11 / 2}{\text { feet, } \$ 1.00}$ each.

CILICIA (Cilieian sllver Fir). A distinct and beautiful species from the mountains of Asia Minor. It is a compact grower, the branches being chickiy set on the stems; foliage dark green: quite liardy. One of the best of the Silver Firs; 4-ineh pots 500 encla; $\$ 4.00$ per 10; balled 2 feet, \$1.50 each.

CONCOLOR. A beautiful Conifer, having lovely sea-green foliage.

Balled, $11 / 2$ fect, $\$ 1.00$ cach.

CEPHALONICA (Ceplialonian-Silver FIr). From Europe. A remarkable and beautiful species; very broad for its height; leaves silvery and dagger-shaped with a spine on the point; quite hardy and vigorous. 4-inch pots, 50e each; $\$ 4.00$ per 10 ; balled, 2 feet, $\$ 1.50$ each.

DOUGLisir (Douglas Spruee, Red Fir. Yellow Fir. Oregon Plne). Height 300 feet; Rocky Mountain region to Pacific; wide range; best development in western Oregon and Washington. Accommodates itself to many soils, but prefers a deep, moist, cool and welldrained one; succeeds well on a dry, slaty soil and on drained one; succeds well on a dry, slaty soil and on all of the Conifers in the rapidity of its growth, and endures much drought. One of the largest and most important forest trees of the West. 3-inch pots, 20e each; $\$ 1.50$ per 10 ; halled 11/2 feet, 60e each; $\$ 5.00$ per 10.

ENGELMANNI. This fine new Conifer is found on the higher parts of the Rocky Mountains. In its most favorable localities this species makes a stately tree, 60 to 100 feet high, forming a narrow tapering spire of a rather dark hue. A suitable tree for reforesting mountain slopes. Balled, 2 to $21 / 2$ feet, \$2.00 each

EXCELSA (Norway Spruce). A lofty, rapid grower, of pyramidal form; very ornamental.

Balled, 1 foot, 50e each; $\$ 4.00$ per 10

FIRMA. A stately tree, attaining in favorable localities a height of 150 feet; branches horizontal, leaves deep glossy green above, paler beneath. A native of Japan. Balled, 2 to $21 \%$ feet, $\$ 1.50$ each

GRANDIS. A majestic and graceful tree, towering to a height of 200 feet; leaves arranged in double rows on the branches, apple green above, silvery beneath; very distinct. 4-inch pots, 35e each, \$3.00 per 10; balled $2 \% 2$ feet, $\$ 2.00$ each.

LASIOCARPA.

Balled, 1 foot, $\$ 1.00$ each Citka Spruce). Alaska and Northwestern Coast; low elevation; moist soil and climate; shady situations. Rapid grower. Balled, 3 feet, \$2.50 eacl.

MERTENSIANA (California Hemlock Spruce). Branches slender, drooping and very numerous. It grows from 100 to 150 feet high, forming a roundish conical
head. An exceedingly rapid grower.

NORDMANIANA (Nordmann's Silver Fir). This majestic Fir from the Crimean Mounta form, vigorous and quite hardy. Its foliage is quite massive, dark green, shining above, and slightly glaucous below, rendering it a very handsome tree throughout the year. Considered here and in Europe as one of the finest of the Silver Firs. 3 -inch pots, 30 each; 6-incl pots, $\$ 1.00$ eaclr; balled 1 foot, $\$ 1.00$ eaeh, balled $21 / 2$ to 3 feet, $\$ 2.50$ each.

PARRYANA GLAUCA. A beautiful sort, with lovely seagreen foliage.

Balled, 1 foot, $\$ 1.00$ each

PINSAPO. A beautiful tree; its compact growth and unique appearance renders it worthy of a place in the garden. The foliage is of a yellowish place in glaucous stripes. B-inch pots, 35e each, \$3.00 per glaucous stripes. 3 -inch pots, 35e each, $\$ 3.00$ per

POLITA (Tiger's Tail Spruee). A distinct Japanese species. It is of erect habit and has rigid sharply pointer leaves of a bright green color. 5-inel pots, 75 eaeh.

\section{ACACIA}

The Acacias are all natives of Australia and Tasmania. The wood is valuable and the bark used extensively for tanning purposes. They are all of rapid growth and produce their various shades of yellow flowers in great profusion. For quick growth and shade-affording purposes we know of no better tree. We offer the following varieties, all pot grown:

BAILEYANA. One of the most ornamental; foliage beautiful sea-green, flowers yellow, balled-shaped; very profuse in bloom. $11 / 2$ to 2 feet, 35e each, $\$ 3.00$ per 10 .

CULTRIFORMIS. Foliage of this variety is triangular in form; color beautiful sea-green; profuse in bloom; of medium-sized growth. A most lovely variety.

12 to 15 inches, 30e each; $\$ 2.50$ per 10

IMPERIALIS. Leaves round, olive-shaped.

12 to 15 inches, $25 \mathrm{e}$ ach; $\$ 2.00$ per 10

LATIFOLIA. Resembles the "Melanoxylon" variety, but leaves are longer, and tree more floriferous. 11/2 to 2 feet, 30e cach, $\$ 2.50$ per $10 ; 4$ to 5 feet, $60 \mathrm{c}$ each, $\$ 5.00$ per 10; 6 to 7 feet, $75 \mathrm{c}$ each, $\$ 6.00$ per 10 .

LOPTHANTHA. Of very rapid growth; very nice when young, but rather coarse as it grows older; where a quick growth is desired this tree will be found dequick growth is desired this tree will be found de-
sirable.
$\mathbf{2}$ to $\mathbf{3}$ feet, 25 each; $\$ 2.00$ per 10

LINEARIS. Long feathery foliage, very beautiful.

3 to 4 feet, joc each; $\$ 4.00$ per 10

MELANOXYLON (Blackwood Tree). A strong upright growing tree. Very desirahle for parks and street ornamentation. 2 feet, 25 e each, $\$ 2.00$ per 10; 3 feet, $40 \mathrm{c}$ each, $\$ 3.50$ pex $10 ; 5$ to 6 feet, $60 \mathrm{c}$ each, $\$ 5.00$ per $10 ; 6$ to 7 feet, 75 e each, $\$ 6.00$ per 10 .

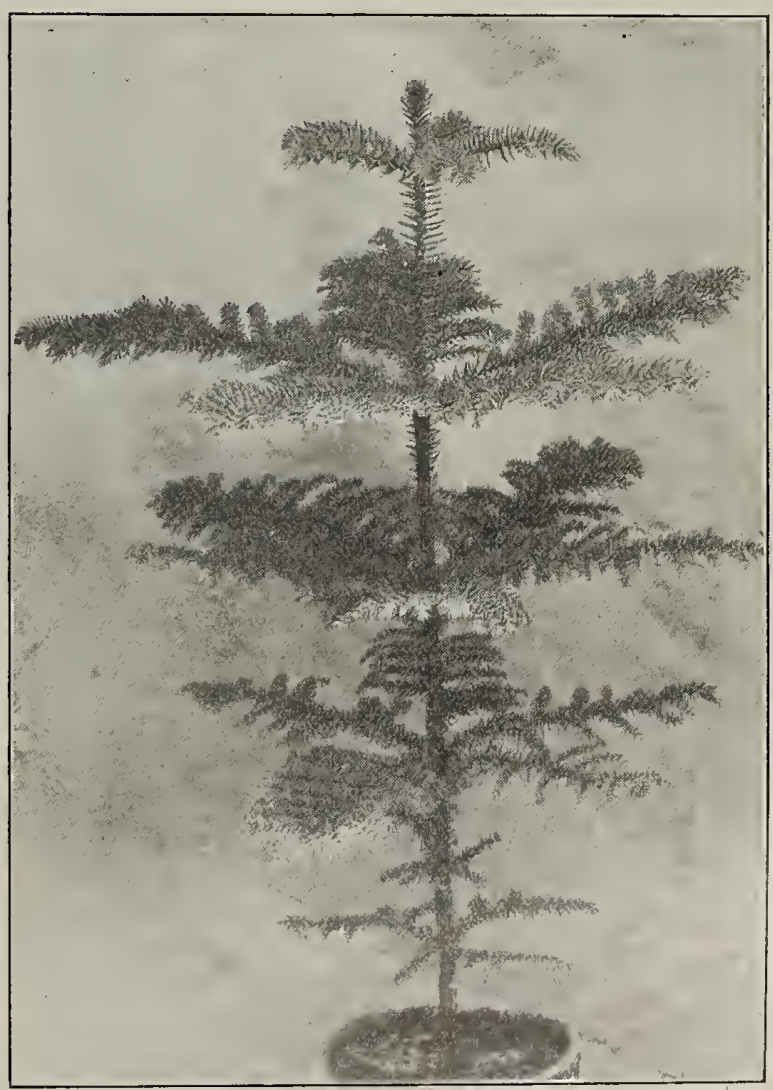

Arauearia Exeelsa. 
EVERGREEN TREES AND SHRUBS-Continued

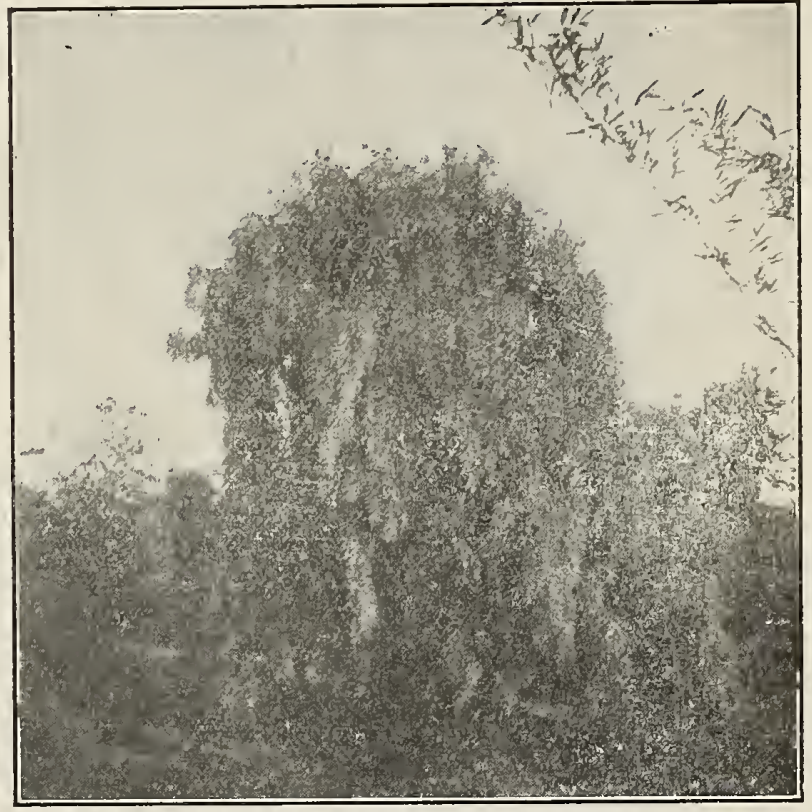

Acacia Retinoides Florabunda

Photo C. C. Morse \& Co.

ACACIA-Continued

MOLLISSIMA. A fine, erect-growing tree, with glaucous green, feathery foliage; flowers yellow, produeed in early spring in rreat profusion. A rapid-growing tree. 2 feet, 35c cach, $\$ 3.00$ per $10 ; 3$ feet, 50c each, $\$ 4.00$ ver 10 .

PARADOXA. Fine for forcing. It produces its flowers in great profusion. Planted outdoors, it is as equally good. $2 \frac{1}{2}$ feet. Bushy plants.
CNANTHA (Golden Watte). Leaves long and narrow,

PYCNANTHA (Golden Watte). Leaves long
flowers in long solitary auxiliary spikes.

2 feet, 30e each; \$2.50 per 10

RETIN OIDES FLORABUNDA. Pendulous habit; seagreen foliage; very floriferous and sweet perfumed. 3 to $31 / 2$ feet, 30e each, $\$ 2.50$ per $10 ; 4$ to 5 feet, 50e
each, $\$ 4.00$ per $10 ; 6$ to 7 feet, $75 e$ each, $\$ 6.00$ per 10.

REASIANA. A variety with small, heath-like foliage; of small growth; very free flowering. Makes a lovely lawn tree. $\quad 3$ fect, $35 c$ each; $\$ 3.00$ per 10

SALIGNA. Leaves long and narrow; sea-green in color: very floriferous. $11 / 2$ to 2 feet, 30 ench, $\$ 2.50$ per 10 .

\section{ARAUCARIA}

Named from Auracanos, the native Chilean name for this tree. We list three varieties, one from Chili, one from Australia, and one from Noriolk Island. Which is the handsomest it is hard for us to say. They are all grand, majestic, noble trees, attaining in time immense proportions.

BIDWELLI. Branches in regular whorls: closely set with spiny, shining, deep-green leaves. Very handsome loalled, 5 feet, $\$ 7.50$ eneh.

EXCELSA (Noriolk Island Pine). One of the handsomest of all trees; pyramidal in form and very symmetrical; hardy in protected locations. Excellent for parlor decorations. Pot grown, 2 fect (very fine), \$3.00 eneli; 3 feet, $\$ 4.00$ ench.

IMBricA TA (Chili Pinc, or Monkey Tree). A fine tree, of regular pyramidal form; leaves bright green, broad, thick, pointed, overlapping each other. Balled, 2 feet, $\$ 3.00$ each; balled, 3 feet, $\$ 4.00$ each; boxed, $21 / 2$ feet. $\$ 4.00$ each; boxed, 3 feet, $\$ 5.00$ eael ; $31 / 2$ feet, $\$ 96.00$ ench.

ARBOR VITAE, GOLDEN. A very choice shrub. It is of slow, compact growth; foliage beautiful goldenyellow. For lawn adornment it is unsurpassed, the yellow foliage contrasting to perfection with the
green lawn.
Balled, 11/2 feet, 75e each
A RDISIA CRISPA. This Japanese shrub is prized chiefly on account of the fine clusters of red berries which it bears at Christmas time in great profusion.

s-incli pots, 50c ench

\section{AUCUBA}

JAPONICA. This shrub is sometimes called the "GoldDust Tree," on account of its large, glossy foliage being marked with yellow spots. It is an extremely beautiful plant, and is of slow, spreading growth. In the warmer sections it should have partial shade. 3-inch pots, 30c each, \$2.50 per 10; large bushy plants, $21 / 2$ fect, $\$ 2.00$ each.

LATIFOLIA VIRIDIS. This variety has dark-green shining foliage; in winter time it is covered with red berries, which greatly enhance its beauty.

4-inch pots, $11 / 2$ feet, 50c each

DENTATA. Leaves deeply cut, glossy and green. 4-inch pots, 30e eacli; \$2.50 per 10

LONGIFOLIA PICTA. Large leaves, beautifully spotted. 4-ineh pots, 30e each; $\$ 2.50$ per 70

SPLENDIDA. This variety has beautifully mottled golden foliage. 4-incli pots, 50e each; $\$ 4.00$ per 10

\section{AZALEA INDICA}

These beautiful plants are becoming more popular every year for forcing, window, store, and conservatory decorations. They are also adapted for outdoor planting. The Azaleas which we offer are all grafted and have bushy crowns, and are well set with flower buds.

We can supply the following named sorts at $\$ 1.50$ each.

APOLLo. Semi-double, dark scarlet.

BER HARD ANDREAS ALBA. Double, pure white.

CHICAGO. Double, salmon, white margin.

DE SCHR YVERIANA. Rich rose, shaded vermilion red, white margin dark red blotch.

DEUTSCHE PERLE. Double pure white.

DR. MOORE. Double deep rose.

EMPEROR OF BRAZIL, Double soft rose: extra fine. GMPRESS OF INDHA. Double, rich rosy salmon.

JOHN LLEWELLYN. Double soft rose, white margin.

MADAME VAN DER CRUYSSEN. Semi-double crimson. NIOBE. Double white; very fine.

PROFESSOR WOLTERS. Single pink, white margin; undulated.

VERVAENEANA. Double, rosy salmon, white margin.

AZARA MICROPHYLLA. A handsome shrub, having small, glossy leaves; orange-yellow flowers.

Pot grown, 11/2 to 2 feet, soc each

\section{BAIIBOOS}

Of late years the Bamboos have been receiving quite a lot of attention from the Californians who are interested in the horticultural development of their State. There are great possibilities in Bamboo culture; the Bamboo pole is useful for many purposes, and there are many places in this State where it can be grown successfully and profitably. The San Joaquin Valley, where there is irrigation, would be a good locality for its culture; they need lots of water, but they must have good drainage.

KUMASASA. Small, slender, grassy foliage.

Clumps, 2 fect, 50c erch MiTIS. One of the largest bamboos; it attains a height of 28 to 38 feet. The canes are used extensively for furniture work, water-pipes, etc.

BLACK. This variety attains a height of 30 feet. The canes are black; used for making walking sticks, canes are black; used for making walking sticks,
clumps, soc each QUILIOI. A very large-growing sort, attaining a height of 40 feet.

BEIRBERIS DARIVINII. This is the finest of all berberis. Foliage thick and leathery; flowers orangeyellow, and deliciously fragrant. Pot grown, 50 each.

\section{THE BOX}

These are useful-some for bordering, some for hedging. and others as single specimens on the lawn. They are all of slow growth, and never attain very large dimensions. None of them produce flowers, but the foliage is handsome. 
ARGENTEA. JAPONICA AUREA.

LACROPHYLLA. NARICULARIS. PARICULARIS. TARILGATA

Balled, 1 to $11 / 2$ feet, 35c each Balled, 1 to $11 / 2$ feet, 35c each Balled, 1 to $11 \%$ feet, 35e ench Balled, 1 to 11 , feet, $35 c$ each Balled, 1 to $11 / 2$ feet, $35 \mathrm{c}$ each Balled, 1 to $1 \frac{1}{2}$ feet, $35 c$ each

BOX, DWARF (Sufiruticosa). A fine small bush, with glossy, roundish leaves. The variety so extensively used for edging.

Strong plants for edglng, 75e dozen; \$5.00 per 100

BREATH OF HEAVEN. See Diosma.

\section{THE BROOIMS}

ANDREANA. The flowers of this variety are yellow and brown; they are not produced for such a long period as those of the Spanish variety, but on account of their oddicy and beauty they are much in demand. 12 to 15 inches, 50c each; $\$ 4.00$ per 10 .

SCOTCH, YELLOW. A very handsome shrub, with drooping branches, covered in the spring, with bright y e $110 \mathrm{ow}$ pea-shaped tive for grouping. $\mathbf{3}$ feet, 50e each; $\$ 4.00$ per 10 .

SPANISH, An upright growing shrub. Flowers yellow, produced very freely in the spring and summer, on long, pendulous, round, leafles branches. Pot grown, 2 to 3 feet, s0e each

WHITE, 12 to 15 inches, 50e each; $\$ 4.00$ per 10 .

\section{CALIFORNIA}

\section{NATIVE TREES}

Under this caption will be found trees indigenous to this State. We advocate strongly the systematic planting of these, so that they be not lost to future generations, as will undoubtedly be the case if some radical change be not effected in forest preservation and forest planting. Why there should be in this country such a lax method of caring for our forests is a wonder to us. In no other country are such methods permitted. As individuals, therefore, it behooves us that we do our very utmost towards reforesting. We head the list with the world famous

CA LIFORNIA BIG TREE (Sequoia or Wellingtonia gigantea). This is the largest tree known to exist on the American continent. The bark is from one to two feet thick. One of the largest trees (the so-called Grizzly Giant of the Mariposa Grove) is 93 feet in circumference at the ground. 4-inch pots, 30c each, $\$ 2.50$ per 10; balled, 3 feet, $\$ 2.50$ each; balled 6 feet, $\$ 4.00$ each.

CALIFORNIA REDWOOD (Sequoia sempervirens). From this tree is obtained the most valuable timber of the California forests. It attains a heights of 200 to 250 feet, and from 8 to 12 feet in diameter. The wood is of a rich brownish red, strong and durable, and makes excellent timber. 4-inch pots, 30e each, \$2.50 per 10; balled, 11/2 feet, s0e ench; balled 3 to 4 feet, $\$ 2.00$ each.

CALIFORNIA LIVE OAK (Quercus agrifolia). A familiar sight in our California landscapes, which adds so much to its beauty.

Balled, $11 / 2$ to 2 feet, 50c each; $\$ 4.00$ per 10
CYPRESS MONTEREY. See page 75.

DOUGLAS SPRUCE. See Ables Douglasll, page 73 .

LAWSON CYPRESS. See page 75.

LIBOCEDRUS. See page 78 .

PINE, MON'TEREY. See page 78.

PINE, PONDERosA. See page 78 .

THUJA GIGANTEA. See page 79

CAMHLLIAS. These showy Japanese shrubs are familiar to nearly every one. They bloom early in spring time, and are a great acquisition to the garden. The waxy odorless flowers are produced very freely. We offer the Double White, 80e to \$1.00 each; Double Pink, soe to $\$ 1.00$ each; Double Red, S0e to $\$ 1.00$ each.

CA MPYOR TREE (Laurus Camphora). A fast-growing, very symmetrical, ornamental tree, thriving in the very poorest soil. A native of Japan. Bright green foliage; well adapted for lawn purposes. 5 inch pots, 2 feet, $40 \mathrm{c}$ each; 5-lnch pots, 3 feet, $60 \mathrm{c}$ each.

\section{CASUARINA}

(Beef Wood, She Oak)

The picture of the Casuarina gives us a good idea of the habit of this beautiful tree. The Casuarina is supposed to be named after the Cassowary, a native bird of Australia (akin to the ostrich and emu) on account of its long plumelike foliage, which somewhat resembles the plumage of that bird. The leafless branches are long and pendulous and dark green in color. They are eminently adapted for forest planting in California. The Casuarinas are of very rapid growth and suit themselves alike to the cold bleak winds of the ocean or the hot interior valleys. The wood is very hard and can be advantageously used for many mechanical purposes. As an ornamental tree, we consider the Casuarina one of our best evergreen trees and as a tree for making windbreaks we consider it has no equal, being of such rapid growth and stands pruning so well. The more it is pruned the denser it becomes. They are indigenous to tropical Australia, and some are found in New Caledonia and India. We offer the following varieties:

EQUISETIFOLIA, 5-inch pots, $21 / 2$ to 3 feet, $35 c$ ench; $\$ 3.00$ per 10.

STRICTA. J-inch pots, 2 to 3 feet, 35 c cach; $\$ 3.00$ per 10 STRICTA. Balled, 2 to $21 / 2$ feet, 30 e each; $\$ 2.50$ per 10 STR ICTA.

SUBRROSA. t-inel, CEDARS

LEBANON. This is another of the large growing evergreen trees; much used for park ornamentation. t5e caels, $\$ 6.00$ per 10 ; balled, 2 feet, $\$ 1.00$ each, $\$ 8.00$ per 10.

DEODARA (Iudian or Himalayan Cedar). Exceedingly handsome; the branches are drooping, and the foliage is silvery green. One of the handsomest of coniferous trees for warm sections; of rapid growth. 5 inch pots. 60e cach, \$5.80 per 10; bulled, 2 to $21 / 2$ feet, $\$ 1.00$ each. 
EVERGREEN TREES AND SHRUBS-Contlnued

CEDARS-Continued

A'TLANTICA GLAUCA. A beautiful sort, with lovely seagreen foliage. Balled, 11/3 feet, 75c cach; balled 3 feet, $\$ 1.00$ each; balled, 6 to 7 feet, $\$ 6.00$ each.

CEANo'THus. Known as California Lilac. It is an everrreen shrub of great beauty, having beautiful blue fluffy flowers borne in great profusion.

15 to 18 inches, 50c each

COTONEASTER. A small growing evergreen of lowspreading habit; small round foliage; producing red berries along its branches, very showy.

5-inch pots, 50e each

CRATAEGUS CUNEATUM. An evergreen species of the Hawthorn family. It is of dwarfish habit with glossy foliage, and has berries of a bright scarlet color about the size of a pea. 4-inch pots, 15 to 15 inches, $35 c$ each

\section{CYPRESS}

GLAUCOUS. A species that is very handsome. The foliage is beautiful sea-green, and the habit of growth is spreading; of very rapid growth.

3-inch pots, $25 \mathrm{e}$ each; $\$ 2.00$ per 10

LAWON. This California species has great beauty. It is of rather an upright growth; the branches droop gracefully, and the follage is of a lovely sea-green color. 4-inch pots, 50e each, \$4.00 per 10; balled, $21 / 2$ feet, 60c each, $\$ 5.00$ per 10 .

LAWSON SILVER. In all respects, save color, this $\mathrm{Cy}$ press resembles the preceding. The foliage is indescribably lovely, being of a rich shade of silvery gray, which is not found in many trees. 4-inch pots, 50e each, $\$ 4.00$ per $10 ;$ balled, $21 / 2$ feet, 60 each, $\$ 5.00$ per 10.

MONTEREY. A native of California, and one of the most desirable of evergreens; stands pruning well; very desirable of evergreens; stands pruning well; very extensively planted for hedges. Transplanted in boxes. feet, $25 \mathrm{c}$ each; $\$ 2.00$ per 10 ; 2 feet, 30c each, $\$ 2.50$ per 10 ; balled, $11 / 2$ to 2 feet, 35e eaeh, \$3.00 per 10 .

CYPRESS ITALIAN. Balled $11 / 2$ to $21 / 2$ feet, 50c eacl

The following four sorts of Cypress are rare and choice, and should be in every coniferous collection:

CYPRESS IN'TER'TEX'TA.

CYPRESS LUTHSCENS.

CYPRESS FRASERII.

CYPRESS WOORLEYI.

Bailed, 21/2 feet, 75e each Balled, 1 foot, soc each Balled, 1 foot, 50c each

Balled, I foot, 50c each

\section{CRYPTOMIERIA JAPONICA}

The following extract taken from the "Florists' Exchange" issue of July 15,1905 , and to whom we are indebted for the accompanying photograph, may be of interest to our readers:

'Here in Japan the timber of 'sugi' (Cryptomeria Japonica) is the most highly valued of all for general building purposes. Trees of 20 feet circumference are not rare in the temple groves around Nikko, and single specimens of larger proportions have been found. The trees always grow as straight as an arrow, without any knots, to the height of over 100 feet. Sugi has been much used in temple building, and there has shown its marvelous resisting power.

"The illustration shows an avenue which has evidently been planted, but your correspondent has seen the trees grow in natural groves as close together as the picture shows them, one tall shaft next to the other, all of even height, branchless to a height of 100 feet or more, as straight as trees can be, shooting perpendicularly out of the fertile soil. Imagining large tracts of hundreds of acres planted with this tree where they would grow as fast as here, attaining a diameter of one foot in 25 to 30 years, a more profitable tree could hardly be thought of."

The Cryptomeria thrives best in a dry, hot climate; therefore it is just the tree for this State. It is of rapid growth, and is very ornamental as a young tree. 4 and 5 -inch pots, 2 to $21 / 2$ feet, $60 \mathrm{c}$ each; $\$ 5.00$ per $10 ; \$ 40.00$ per 100 . Balled, 3 to 4 feet, $\$ 1.00$ each; $\$ 8.00$ per 10 .

\section{DAPHNES}

The Daphnes are, we think, very familiar to most of our readers. To those who do not know them we will try and describe them. They are evergreens; the leaves are very pretty; but it is the flowers that attract attention when they are in blossom in early spring; they are small, sweetly scented, and appear in great profusion. They come in two separate colors-pink and white.

Pot grown, $11 / 2$ feet, $\$ 1.00$ each

DIOSMA ALBA (Breath of Heaven). This shrub never attains large proportions. It produces small white star-shaped flowers in great numbers. The foliage when bruised emits a sweet fragrance. 3-inch pots, 10 to 12 inches, 30e each; 4-inch pots, 15 to 18 inches, busliy, 50c each; balled, 1 foot, 50c each.

EUGENIA APICULATA. A very pretty shrub, of small growth with pretty sweet smelling white flowers, something like the myrtle. 4-1nch pots, 35c each.

\section{EUCALYPTI}

There is no doubt in our mind but that the Eucalypti are destined to become the forest tree for this State, just as the Redwood and Big Tree have been in the past. They are all natives of Australia, the climate of which in many respects is similar to our own. The rapidity of growth, the durability of the timber and adaptability to almost any California climate or soil are recommendations which appeal very forcibly to us.

AMYGDALINA, Pepper Gum. Belonging to this variety are the tallest trees in the world. In Gippsland, Australia, are trees over 500 feet in height; makes firstclass timber for flooring, boards, scantling, etc., and is well suited for avenue planting; yields more essential oil than any other variety.

Pot grown, 11/2 to 2 feet, 25e each; $\$ 2.00$ per 10

CREBRA, Ironbark. A moderate sized tree. Timber red, very valuable, hard, tough, inlocked and strong: much esteemed by coach-builders and wheelwrights for poles and poles and shafts of carriages, and the construction of bridges. Thrives well inland in the construction of bridges. Thriv

Pot grown, 2 to 3 feet, 25 e each; \$2.00 per 10

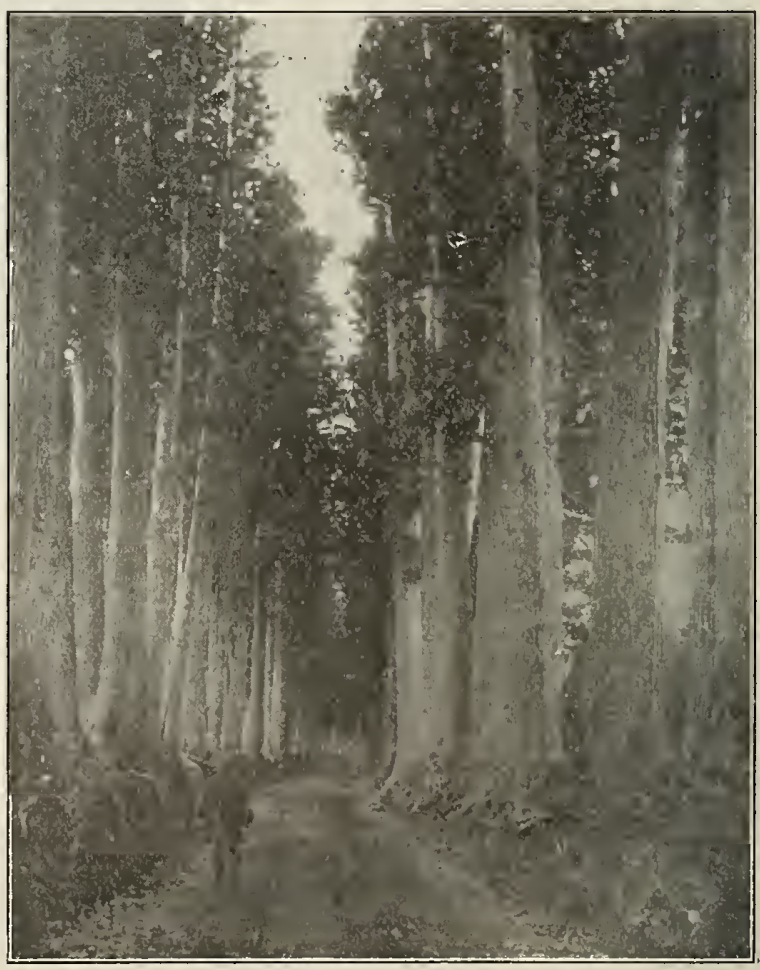

A Forest in Japan of Cryptomerla Japonica 
CAMIBAGEII. A tree about 80 to 100 feet high and 3 to 4 feet diameter. Grows well in hilly or mountainous country. Timber hard and close grained; used for fencing material, building purposes and makes good fuel. $\quad$ Trunsplanted in boxes, \$3.50 per 100

CituriodorA, Lemon-Scented Gum. A unique variety; leaves highly perfumed, like Lemon Verbena.

Pot grown, 25e each

CORIACEA, White Gum. A tree of 80 to 100 feet in height and 4 feet diameter, of handsome appearance, with drooping branches. The follage is eaten by cattle and sheep in dry seasons. It is a very hardy Eucalypt, and grows well in swampy lowlands, and thrives in cold climates, and is not affected by snow. Timber used for building and fencing purposes. Transplanted in boxes, \$3.50 per 100.

CORYNOCALYX, Sugar Gum. Very ornamental; rapid growing; with dark green leaves; timber very durable and used for railroad ties; one of the best.

Pot grown, 10 to 12 inches, 15 e each; $\$ 1.00$ per 10.

FICIForIA, Scarlet-flowering Gum. A beautiful sort, bearing lovely scarlet flowers, thick leathery leaves; hardy only in warmer sections.

Pot grown, $11 / 2$ feet, 50c each; $\$ 4.00$ per 10

GrobUrus, Tasmanian Blue Gum. One of the most useful of all and a vely rapid grower. Pot grown, 2 feet, 15e each; $\$ 1.25$ per 10 ; pot grown, 3 feet, 25c each; $\$ 2.00$ per 10; pot grown, 4 feet, 35e each, \$3.00 per 10 . Balled, 2 to 3 feet, $25 \mathrm{c}$ each, $\$ 2.00$ per 10 ; transplanted in boxes, $\$ 2.50$ per $100 ; \$ 20.00$ per 1,000 .

HEMIPHLOIA (Common Box). Wood very hard, strong and durable above ground; also makes a first class
fuel.

MARGINATA, The Jarrah of West Australia. Famed for its indestructibility; used largely for shipbuilding, railwav sleepers, piles for jetties, and all purposes where strength and durability are required. Pot grown, 11/2 to 2 fect, 20 e each; $\$ 1.50$ per 10.

PIPERITA (Peppermint Gum). Timber valuable for fence rails, shingles, etc.; yields a greater quantity of oil than any other variety; of remarkable, quick growth. Transplanted in boxes, $\$ 3.50$ per 100

PLATYPHILLA. Transplanted in boxes, \$3.50 per 100

OBLIQUA (Stringy Bark). A quick grower and produces the best wood for flooring, scantling and shingles; also used in the manufacture of paper. Inferior as fuel, but makes the best charcoal for the forge.

POLYANTHEnA, Red Box. A moderate grower, perfectly hardy; timber valuable for underground work, being remarkably hard and durable; one of the handsomest of the family; very graceful in habit; foliage silver gray. Pot grovvn, 2 feet, 20 c each; \$1.50 per silver gray. Pot grown, 2 feet, $20 \mathrm{c}$ each;
10. Pot grovvn, 3 feet, $30 \mathrm{c}$ each; $\$ 2.50$ per 10.

ROBUSTA, Swamp-Mahogany Gum. Well adapted to low ground and also to the driest locations; very symmet rical while young; quite brittle as it grows older; branches directly opposite in regular whorls; foliage large, of a deep, glossy green color; flowers large, creamy-white; blooms late in the fall; very much creamy-white; bloom
prized by apiarists.

Transpianted in boxes, $\$ 3.50$ per 100

ROSTRATA, Red Gum. Well known and highly esteemed. Pot grown, 15 to 18 inches, $15 \mathrm{c}$ each, $\$ 1.00$ per 10;

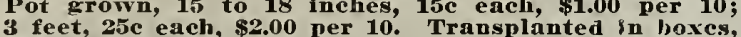
$\$ 3.50$ per 100 .

SALIGNA, Weeping Gum. Very ornamental; leaves and general habits are like the Babylonian Willow. Good for fuel. Transplanteal in boxes, \$3.50 per 100

STUARTIANA, Appic-Scented Gum. Of medium growth, quite erect and stocky; a great resister of frost, enduring temperatures as $10 \mathrm{~W}$ as 10 to 18 degrees $F$. Valuable for wind-breaks; timber useful for fence posts and for fuel. Transpianted in boxes, \$3.50 per 100

VIMINALIS, Manna Gum. A rapid-growing variety and very hardy; on rich soil it grows to a gigantic size; the young bark and leaves yield Australian mannaa hard, opaque, sweet substance.

Pot grown, $1 \frac{1}{2}$ to 2 feet, 25 e ench; $\$ 2.00$ per 10

EUONYMUS, GOLDEN VARIEGATED. A very handsome shrub, having the leaves beautifully marked, goldenyellow; colors up better when planted in a warm spot in the garden. 4-inch pots, 25e each, \$2.00 per 10

EUONYMUS, SILVER VARIEGATED. A very pretty or namental shrub; the foliage is silvery yellow.

Balled, $11 / 2$ to 2 feet, 50c each N YUS, DUC D'ANJOU. Golden blotch in center of leaf. Pot grown, 2 fcet, 50c each, \$4.00 per 10

FABIANA IMBRICATA. A very pretty heath-like shrub of ereat growth, producing pure white tube-shaped flowers in great profusion. When in bloom it is a most lovely shrub. 4-inch pots, 25c each

GREVILLEA ROBUSTA (Austrailan Silk Oak). A splendid fern-leaved evergreen tree, which makes a mag- nificent pot plant for all sorts of decorative purposes; flowers golden yellow; planted out in this State, it sow

5-Inch pots, 3 to 4 feet, $60 \mathrm{c}$ each

HABROTHAMNUS ELEGANS. A strong-growing shrub bearing panicles of small trumpet-shaped, purplish red flowers: makes a grand showing on a lawn or trained against a wall or porch.

Pot grown, 2 feet, $25 \mathrm{c}$ each

HEATH, MEDITERRANEAN. This variety is most desirable; it produces its small wax-like pink flowers in wonderful profusion.

4-inch pots, 12 to 15 inches, 50c each HEATH, WHITE. A beatuiful sort; white flowers.

4-inch pots, 12 to 15 inches, 50e each

HEATH, RED. This variety has red flowers.

4-inch pots, 12 to 15 inches, 50e each

HoLLY, EURopeAN. A small tree, with shining darkgreen thorny leaves, somewliat resembling the oak

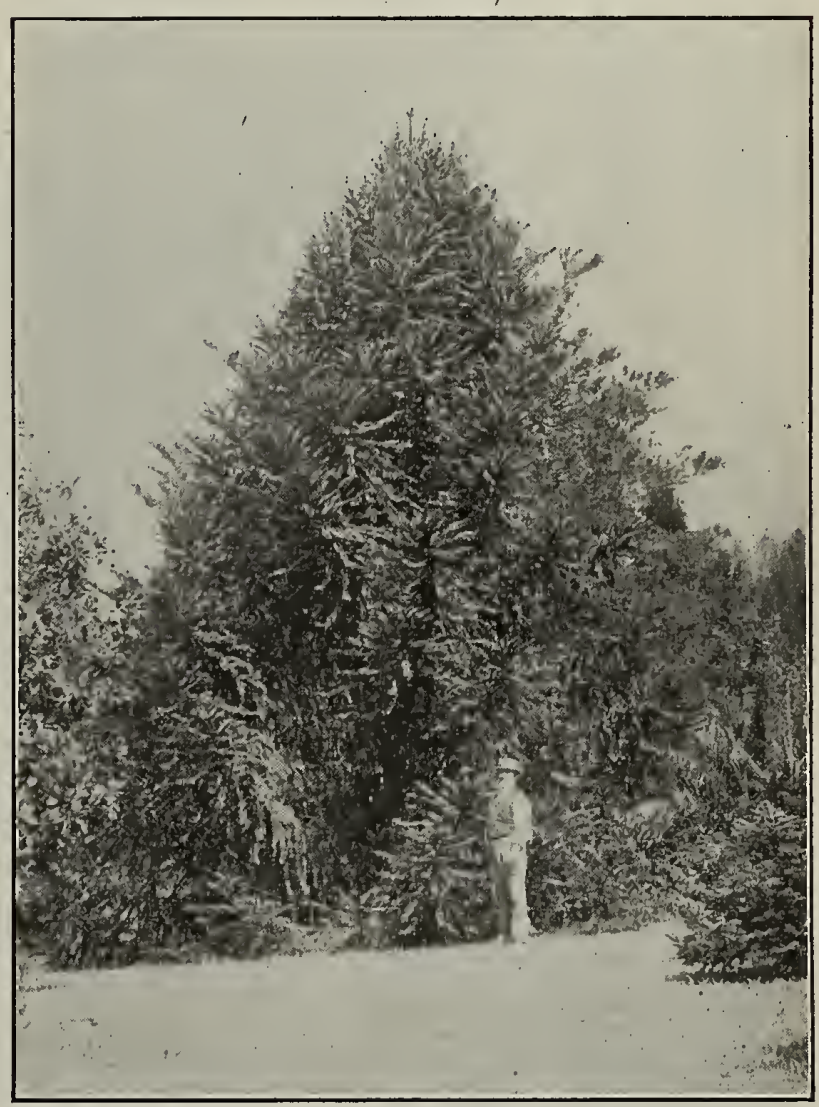

Araucaria Bidwelli

Photo C. C. Morse \& Co.

in form. In winter the tree is covered with bright red berries. 5 -inch pots, 12 to 15 inches, 50 each; bailed, $11 / 2$ feet, $75 \mathrm{c}$ each.

HoLLY, GOLDEN. Bailed $1 \frac{1}{2}$ to 2 feet, $\$ 1.00$ each

JACARANDA MIMOSIFOLIA. A beautiful evergreen shade tree, with fine acacia-like foliage; it produces a handsome, showy blue flower. Much used in the southern part of the State as a sidewalk tree; not hardy in colder section.

JUNIPEIR, IRISH.

3 to 4 feet, $50 \mathrm{c}$ eacl

AURY, ENGLISH, A fine evergreen, with broad shin ing green leaves; produces large panicles of cream white flowers, followed by purple berries.

LAUREL, PorTUGAT. Balied, 2 to $2 \frac{1}{2}$ feet, $60 \mathrm{c}$ each LAUREL, SWEET BAY. A very ornamental, upright growing shrub, with deep, dark-green, fragrant leaves, and covered in the fall with berries. If properly pruned, one of the handsomest of decorative smyrna figs and impart a peculiarly pleasant flavor to the fruit. 5 -inch pots, $11 / 2$ feet, 50c each; bailed, $11 / 2$ to 2 feet, $50 \mathrm{c}$ each. 


\section{EVERGREEN TREES AND SHRUBS-Continued}

LAURUSTINUS. A well-known winter flowering shrub, of great beauty, producing an abundance of white flowers; well adapted for hedges. 5-inch pots, 11/2 to 2 feet, 50e each; balled, 2 feet, 50c each; $\$ 4.00$ per 10 LIBOCEDRUS CIILENSIS. A beautiful variety.

Pot grown, 50c each

LIGUSTR U J JAPONiCUM (Japan Privet). Produces large clusters of white flowers, slightly fragrant, followed by purplish blue berries; leaves glossy, leathery, dark gy purplish blue berries; leaves glossy, leathery, dark green. A large-growing shrub (or small tree). Makes an excellent hedge; stands trimming well. It
also makes a very handsome sidewalk tree when trimmed up. Balled, $11 / 2$ feet, 30c each; $\$ 2.50$ per 10 ; 3 feet, 50e each; $\$ 4.00$ per 10 .

Lig USTRUM OVALifolidi (California Privet). A valuable hedge plant, stands pruning well, and is of rapid growth.

2 to $21 / 2$ feet, $15 c$ each; $\$ 1.00$ per $10 ; \$ 8.00$ per 100

LIGUSTIU to $21 / 2$ feet, 15e each; $\$ 1.00$ per 10; $\$ 8.00$ per 100 beautiful golden foliage.

$$
11 / 2 \text { to } 2 \text { feet, 35e eneh; } \$ 3.00 \text { per } 10
$$

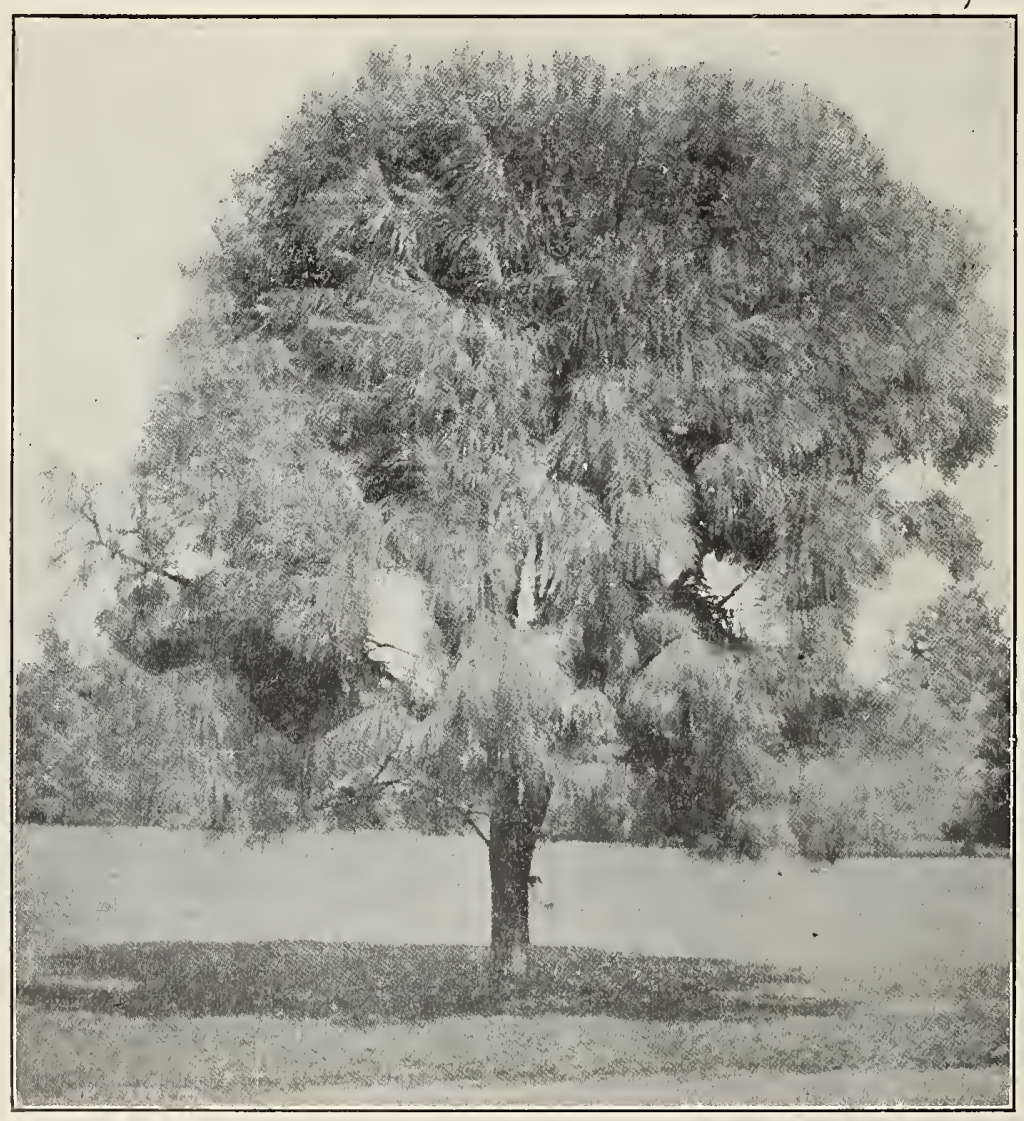

Casuarima Strictal. Beef Wood of Australia. Photo C C Miorse \& Co.

HAX. Has large sword-like leaves, of a deep rich green color. From this plant flax is made in New Zealand. Very ornamental 50e and \$1.00 each plant, DoMESTICA. A beautiful, upright-growing stems, growing from the same root, crowned with deep glossy green foliage, and with tall spikes of white flowers. The young growth is prettily tinged with red. In the fall it is covered with masses of small red and white berries.

$75 \mathrm{c}$ ench

OLEA FRAGRANS. A little-known Japanese shrub; desirable on account of its pretty foliage and sweetly fragrant, small white flowers. We recommend it, as we know it will give satisfaction.

Pot grown, 3 feet, $\$ 1.00$ each

\section{THE OLEANDER}

Best suited for the warmer sections, where, if given plenty of water, it thrives to perfection. The flowers are produced very freely for a long period. One of the showiest of ever-blooming evergreens.

ALBUM PLENUM. Double white; sweetscented; very good.

Balled, 2 to $21 / 2$ feet, $50 \mathrm{c}$ each

IADAME SARAH BER NHARDT. Beautiful rose color, center streaked light crimson; very large trusses. Balled, 2 to $21 / 2$ feet, 50c each

PEPPER TrEe. A most popular shade and ornamental tree, with fine feathery foliage; producing clusters of reddish berries in autumn. 3 inch pots, 12 to 15 inches, $25 \mathrm{c}$ each; ineh pots, 12 to 4 -ineh pots, $11 / 2$ to feet, 35e each; $\$ 3.00$ per 10.4 to 5 feet, 60c each; $\$ 5.00$ per 10 .

\section{PINES}

MONTEREY. The most desirable pine for shade, and more extensively planted than any other variety in this State 4-inch pots, 2 to $21 / 2$ feet, 30e each; \$2.50 per 10 . 4-inch pots, 3 to 4 feet, $40 \mathrm{c}$ each; $\$ 3.50$ per 10 Balled, 4 to 5 feet, 60e each; $\$ 5.00$ per 10. 6 to 7 feet, $75 e$ each; $\$ 7.00$ per 10.

sCoTCH. A fine, robust, rapid-growing tree, with stout, erect shoots and silvery-green foliage. Pot grown, $11 / 2$ to 2 feet, 25e each: $\$ 2.00$ per 10 . per 10 .

CAYARIENSIS, A quick-growing pine with beautiful glaucous foliage. Pot grown, 1 foot, 25c each; $\$ 2.00$ per 10. Balled, 21/2 feet, 35c each; $\$ 3.00$ per 10.

Ponderosa ("Yellow Pine"), Very rapid grower: one of the great timber trees of California. 3-inch pots, 12 to 15 inches, 250 each; \$2.00 per 10

STRoBUs (Weymouth Pine). A compact grower, with light gi.eer, silvery foliage. A handsome tree. 4 inch pots, 1 foot, 25 e cach; $\$ 2.00$ per 10.

PINEA (Parasol, or Stone Pine). This very picturesque tree thrives best in a sandy soil in a sheltered situation, branches spreading like a parasol and usually confined to the parasol and usually confined to the
top of the tree. A feature of the
thern Italy. Balled, 2 to $21 / 2$ feet, landscape in Southern

LOQUAT. This tree produces a very delicious fruit, which ripens in early summer; it comes in clusters, and is yellow in color. It is also valuable as an ornamental tree; the leaves are large, crumpled and olive-green in color. Pot grown, 2 to $21 / 2$ feet, $50 e$ each

MAGNOLIA GIRANDIELORA OXONIGNSIS. A lovely evergreen species, with large, leathery, bright green leaves that look as if made of wax, a foot or eighteen inches long and four inches wide. In addition to the beauty of the foliage, it bears large fragrant white flowers Very choice. Strong pot grown plants.? flowers. Very choice. Strong pot grown plants, 2 feet, $\$ 1.50$ each.

METROSIDEROS SEMPERFYORENS. Commonly known as "Bottle Brush." Produces curiously shaped, scarlet flowers in sliape of a bottle brush; very handsome and showy.

Pot urown, i1/2 feet, 50c each

MYRTLE, COMMON. A dwarf shrub, with shining green leaves and fragrant white flowers.

Pot grown, 2 fect, 50e each
PHO'TINIA SERRULATA. A handsome shrub attaining a height of 15 feet, with glossy, green leaves, assumflowers small, white; in large terminal flat corymbs. Balled, 5 feet, $\$ 1.50$ each

\section{PITTOSPORUM}

NIGRICANS. A very handsome, upright growing shrub, with silvery light green leaves and black stems. A cood hedge plant, and very ornamental as an individual. Pot wrovn, $11 / 2$ feet, 25 e each; $\$ 2.00$ per 10. $21 / 2$ feet, 35e each; \$3.00 per 10.

EUGEVoIDES, A large, upright growing shrub, with glossy yellowish green leaves; a very effective shrub, and excellent for liedges. Pot grown, 12 to 15 inches, 25e each; $\$ 2.00$ per 10 . $21 / 2$ feet, 35e each; $\$ 3.00$ per 10 . 
TOBIRA. A very desirable sort; the foliage and stems are very stiff; flowers pure white, sweetly scented; of dwarf habit. Balled, $1 \frac{1}{2} / 2$ feet, 35 e each; $\$ 3.00$ per 10 .

UNDULATUM. Flower's sweetly scented; very desirable. Pot grown, 11/2 fect, 30c each; $\$ 2.50$ per 10. Balled, $11 / 2$ feet, 35e ench; $\$ 3.00$ per 10 .

POLYGala dalmatiana. A profuse flowering shrub, with purple pea-blossom-shaped flowers, and pretty with purple pea-blossom-shaped flowers, and pretty
light green foliage. Pot grown, $11 / 2$ feet, 35c each

PRIVET. See Ligustrum.

REDVOOD. See page 75

RETINOSPORA OBTUSA. A new and rare sort; leaves very much flattened, coral-like in appearance, and of a lovely dark-green shade of green.

Pot grown grafted plants, 12 to 15 inches, 50c each

\section{RHODODENDRONS}

These are among the grandest of our hardy fiowering shrubs, and cannot be surpassed for lawn decoration. The flowers range through shades of rose, pink, crimson, white, etc. Should be planted in partial shade. We have a magnificent European collection to offer. Price, $\$ 2.00$ and $\$ 2.50$ each.

BOULE DE NEIGE. Pure white; fine large truss.

CARACTACUS. Rich purplish-crimson; very large truss. JACKSONII. Light rose, with dark spots; free bloomer.

KATE WATGRER. Clear rosy crimson.

MRs. FITZGGRALD. Bright rosy scarlet; exceedingly fine.

MAD. WAGNER. Scarlet; dark spots on petals.

MLLE. MASON. Pure white; yellow stripes.

PURITY. White, faintly suffused with yellow.

SPRUCE. . See Abies.

SWAINSONA GREYANA (Darling River Pea). Flowers rose colored, produced in sprays of from twelve to twenty flowers each, in individual blooms resembling the flowers of a sweet pea. Leaves small; acacia-like. A most desirable ever-blooming plant. Native of New South Wales. 4-inch pots, 35e each

SWAINSONA GALEGIFOLIA ALBA. This variety has delicate white flowers.

SWEET BAY. See Laurel.

\section{THUJA}

GIGANTEA. A very ornamental, fast-growing California arbor vitae, attaining great size.

Balled, 4 feet, \$2.50 each

GIGANTEA LUTEA. Of dwarf, compact habit

Balled, 1 foot, soe each

FILIForuIs. A choice sort with cord-like foliage.

Balled, $11 / 2$ feet, $75 \mathrm{e}$ each

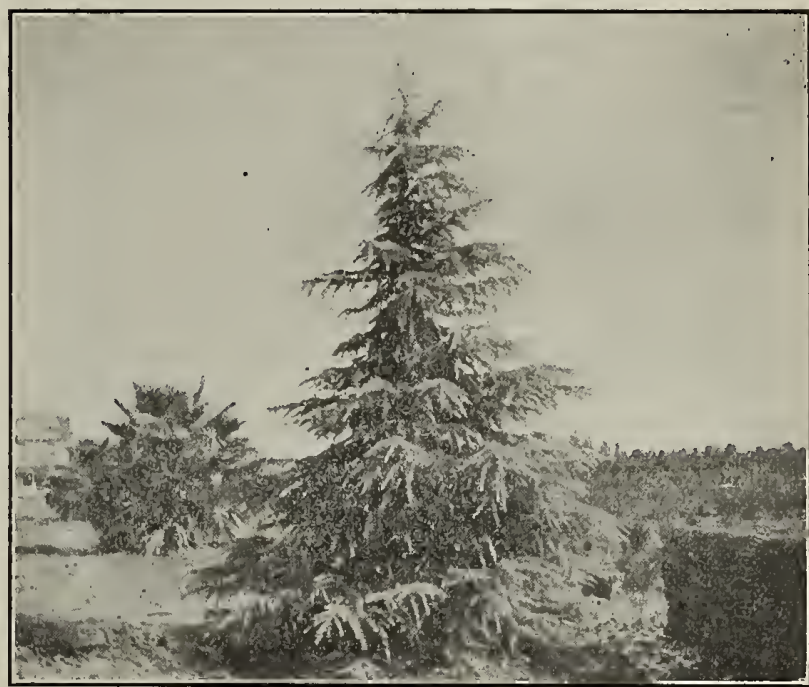

Cedrus Deodora. Indian Cedar Photo C. C. Morse \& Co.

LOBBII AUREA. Foliage beautifully tinted goldenyellow. $\quad$ Balled, 12 to 15 inches, 50c each

THUJOPSIS DOLOBRATA. Leaves shining green above, silvery white beneath; of pendulous and dwarfish habit; branchlets coral-like in appearance; very handsome. Pot grown, 2 to 3 feet, $\$ 1.00$ each

VERONICA IMPERIALIS. The finest of the species. Flowers amaranth. 2 feet, 50c'each

VERONICA TRAVERSII. A most desirable sort; of dwarf habit; flowers pure white; good for making small hedges. $\quad 4$-inch pots, $30 \mathrm{c}$ each; $\$ 2.50$ per 10

\section{YEW}

ENGIISH. A densely branched, spreading tree; foliage dark and sombre: a good sort for clipping into artificial forms. 4 -inch pots, 35e each; $\$ 3.00$ per 10

ENGLISH GOLDEN. A golden, variegated kind of the preceding. This tree "colors up" beautifully during the summer months. 4-inch pots, 35e each; $\$ 3.00$ per 10

IRISH. An upright growing variety, with deep dark green foliage; branches erect, closely compressed, forming a pyramidal shaped head; a very distinct and beautiful variety.

4-inch pots, 1 foot, 35c each; \$3.00 per 10

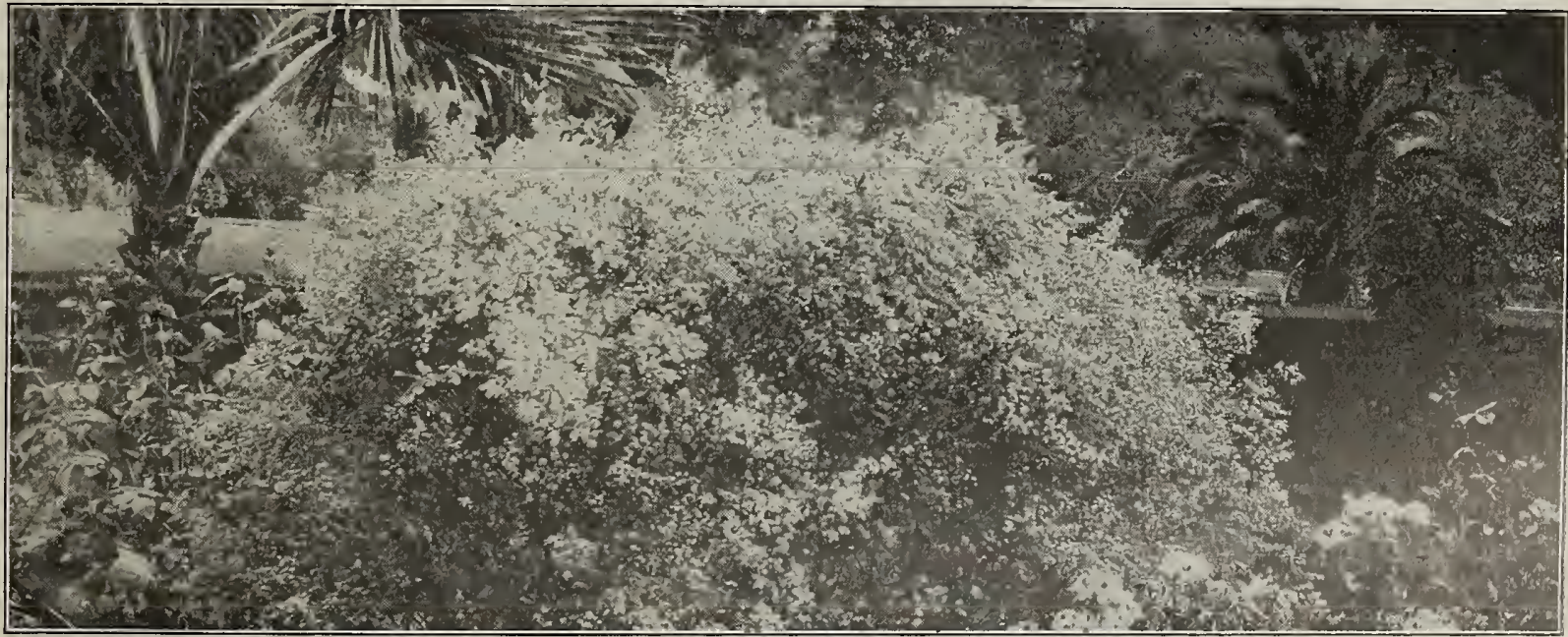




\section{Deciduous Trees and Flowering Shrubs}

ALTHEA. One of our showy ever-blooming deciduous Pink. 2 to $21 / 2$ feet, 30c cach; $\$ 2.50$ per 10

AMELA CHIER BOTRYAPUIM. IS nown as "June Berry," "Wild Pear," "Service Tree," and "Shad Blow." Grows 30 to 40 feet high. Flowel's white, produced in great profusion early in April, succeeded by a small fruit of purplish color. One of the finest very early flowering trees.

ASI. AMERICAN. 3 to 4 feet, 35c each; $\$ 3.00$ per 10 . 6 to $S$ feet, 50c each.

ASH, EUROPEAN, A lofty tree of rapid growth, with spreading head and gray bark; pinnate leaves and
black buds.
$\mathbf{3}$ to 4 fect, 35 each; $\$ 3.00$ per 10

AZALEA Moldis. A native of Japan, and undoubtedly one of the most beautiful shrubs for forcing or planting in groups or borders in parks and gardens.. The flowers are larger and of more perfect form than flowers are larger and of more perfect form than the flowers of the Azalea Indica. Their gorgeous the flowers of the Azalea Indica. Their gorgeous yellow to richest orange. Large strong and bushy named plants.

AZALEA PONTICA. This is one of the most beautiful varieties of hardy shrubs. Their flowers vary from the purest white to the most gorgeous scarlet and crimson; sweetly fragrant. Our list embraces all the most distinct and handsome named varieties; the plants we offer are strong and well set with buds.

B E E II, PURPIELEAVED. Foliage is deep purple in spring, changing to crimson in the fall.

4 to 5 feet, $\$ 1.50$ each

BIRCH, EU R O PA N WHITE. Remarkable for its elegance; very graceful, with silvery bark and sle nder branches. 4 fect, 50c each; 6 fect, $75 \mathrm{c}$ each.

B I R C H, CU'T-LEAVED WEEPING. A charming tree with deeply lacinated foliage. Its tall, slender, yet vigorous growth, graceful, drooping branches, silvery-white b a $r k$, and delicately cut foliage, presents a combination of attractive characteristics rarely met with in one tree. 6 to $S$ fect, $\$ 1.50$ each

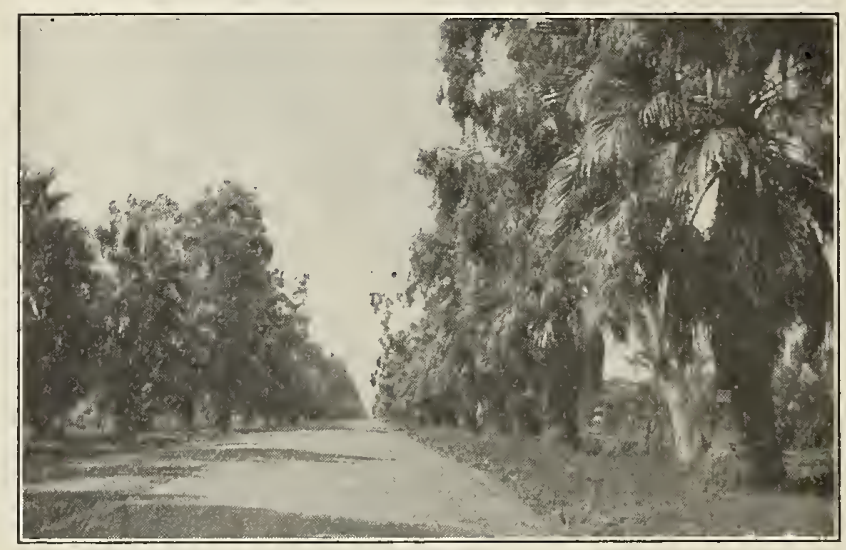

A California Road Beautified with the Planting of 'Trees; contrast this witl one unplanted. unplanted.
GRRY, Japanese Double Flowering. A very ornament flameir flowers in great masses, and when in blossom they present a . White and Double Rose varieties. 3 fect, 50c cach; \$4.00 pcr 10

CIAA APPLE, Betchell's Double Flowering. One of the most beautiful of the many fine varieties of flowering Crabs. Tree of medium size, covered in early spring with large, beautiful, double fragrant flowers of a delicate pink color. From a distance the flowers have the appearance of small roses. A great acquisition, and certain to become very popular as soon as known. Blooms when quite young.

4 to 5 feet, 60c each; $\$ 5.00$ pex 10

CHESTNUT, AMERICAN. A noble large-growing tree, at first of slow growth, but eventually growing with fair rapidity.

5 to 6 feet, 50c each

ANTHUS VIRGINICUS (White Fringe). A small native tree or shrub, of roundish form, with large, flowers, having narrow, fringe-like petals; blossoms in May or June. A superb lawn tree.

3 feet, 40e each; $\$ 3.50$ per 10

CORCHor US JAPONICUS. Produces globular-shaped, deep white flowers for a long period; foliage slender and graceful.

CRAPE MYRTLE. Words fail to convey an adequate idea of the beauty of this shrub. They succeed best in a warm section and blossom for a long period; the fowers have curiously crimpled petals. We can supply the Red and whlte varieties.

2 to 3 feet, $50 \mathrm{c}$ each

CURRAN'T, FLOWERING. Produces pink flowers very early in spring; much admired.

2 to 3 feet, $25 \mathrm{e}$ each

\section{WEUTZIA}

We are indebted to Japan for this valuable genus of plants. Their hardihood, fine habit, luxuriant foliage and profusion of attractive flowers, render them among the most beautiful of flowering shrubs. The flowers are produced in May and June.
BOX ELDEIR. See under Maple.

CALYCAN'THUS FLORIDUS (Sweet Shrub). A very desirable shrub, with flagrant wood and foliage; flower of a rare chocolate color.

2 to 3 feet, 35 c each

CA'IALPA SPECIOSA (Vestern Catalpa). Leaves large heart-shaped; of rapid growth; flowers come in long grape-like clusters of white and purple; very fragrant. The timber obtained from this tree is valuable. 6 to 7 fcet, 60e cach; $\$ 5.00$ per 10

CATALPA BUNGEI (Chinese Catalpa). Of dwarf habit, growing only four to five feet high; foliage large and glossy; eminently adapted for lawn planting, where it makes a lovely specimen, as it is of very bushy habit and shows off to great advantage.

2 to $21 / 2$ feet, 50e cach; $\$ 4.00$ per 10

CA'TALPA KAEMPFERII (Japan Catalpa). Of rapid growth, with deep green glossy foliage. Flowers fragrant, cream-colored.

6 to 7 lect, 60e each; \$5.00 per 10

CER CIS CANADENSIS (Judas Tree, or Red Bud). A very ornamental native tree, of medium size, irregular rounded form, with perfect heart-shaped leaves of a pure green color, glossy surface above, and grayish pure green color, glossy surface above, and grayish
green beneath. The tree derives the name of Red Bud from the profusion of delicate reddish purple flowers with which it is covered before the foliage appears. Flowering at the same time with the Chinese Magnolias, it may be planted among them in groups with tine effect. Grown as single specimens they are also beautiful and attractive, and deserve to be classed among our finest ornamental trees.

4 tó 6 feet, soc cach
GRACILIS. A charming species of dwarf habit; flowers pure white; produced in great masses in spring time.
Excellent for pot culture.

LEIOINEII. Flowers pure white, borne on stout branches, which are of upright growth; free flowering. 2 to $21 \%$ feet, $35 \mathrm{c}$ cach

PRIDE OF ROCHESTER. Flowers double white, reverse of the petals slightly veined rose.

2 to $21 / 2$ fect, 35e each

DOGWood (Red Siberian). A valuable shrub; branches bright red. 2 to 3 feet, $30 \mathrm{c}$ each

ELM, AMERICAN BIACK. A magnificent large tree, with drooping, spleading branches; one of the grandest of our native forest trees.

4 to 5 fect, 50c each; $\$ 3.50$ per 10

ELI, WNGLISH OR FRENCH. An erect, lofty growing tree, of rapid, compact growth, with smaller and more regularly cut leaves than those of the American Elm. 4 to 5 feet, 50e eacli;

ELM, BROAD-LEAVED ENGLISH (Latifolia). GoFAGNus EDULIS. In July the plant is covered with bright red berries of large size. Laden with fruit bright red berries of large size. Laden with fruit the bush is highly ornamental, and the fact that the additional value for garden decorations.

EUSCAPLIES STAPHYLEOIDES, Produces white or yellowish flowers, borne in terminal panicles, succeeded by red, bladdery fruit, remaining on the bush till late in winter. This plant is highly regarded in Japan, of which it is a native, for its medicinal properties. 


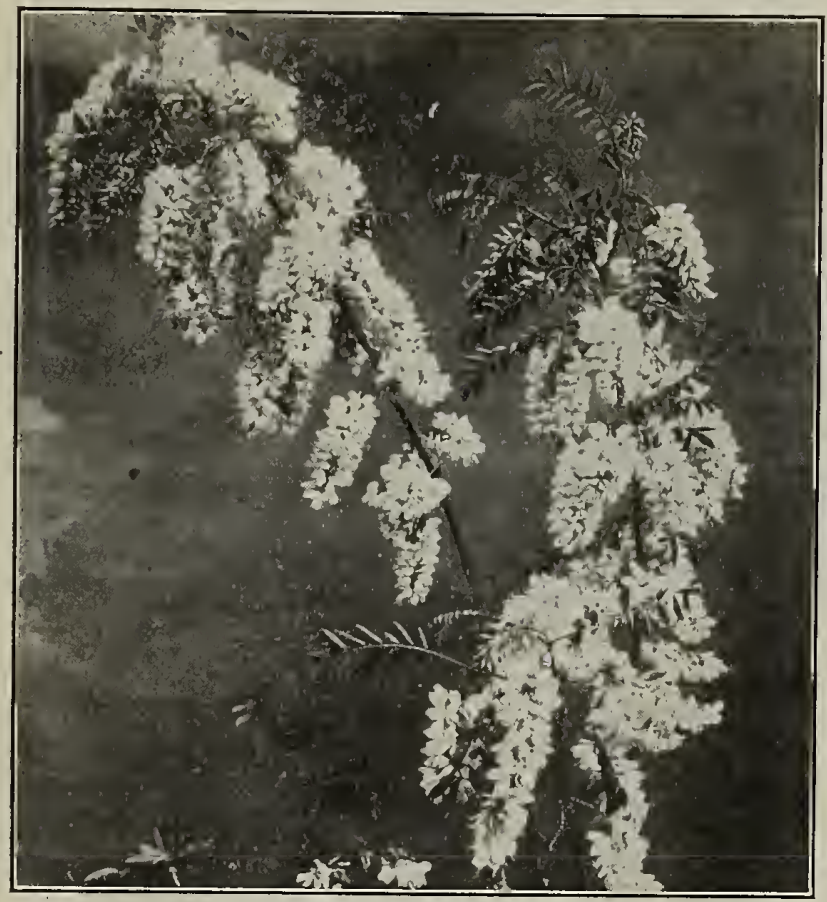

Pink Flowering Loeust

Photo C. C. Morse \& Co.

EXOCHORDTA GRANDIFLORA. A beautiful, tall-growing shrub, native of China, bearing beautiful racemes of handsome white flowers, appearing in May. A rare and choice shrub; should be in every collection.

2 to $2 \frac{1}{2}$ feet, 35e each

FORSYTHIA SUSPENSA (Golden Bell). One of the earliest of spring flowering shrubs, being completely covered with tufts of rather large, pendulous bright yellow flowers, which grow two or three together from all parts of the rod-like branches.

Hawthorne. See Thorn.

2 to 3 feet, 35 e each

HONEYSUCKLE, TARTARMAN (Upright or Bush). This variety of Honeysuckle is a bush sort, excellent for the formation of hedges; have beautiful creamy-white flowers.

3 feet, 35e each; $\$ 3.00$ per 10

Horse CHESTNUT, EUROPEAN. Of majestic appearance, bearing large clusters of beautiful white flowers, succeeded by mahogany-colored nuts. inclosed in burrs; the leaves are palmateshaped.

4 to 5 feet, $75 c$ each

HYDRANGEA PANICULATA GRANDIFLORA. This is one of the finest of all hardy shrubs for the lawn or border. The flowers are white, spiked-shaped, and are produced for a long period during summer and fall.

$11 / 2$ to 2 feet, 35 e eaeh; 3 feet stems, 80e each

HYPER ICUM MOSERIANUM. It produces long, slender, much-branched stems. It is marvelously free-flowering; of large size; a rich golden-yellow, which is rendered still more effective by the numerous yellow stamens and crimson anthers, and blooms continuously the entire season.

Strong plants, 35e each; $\$ 3.00$ per 10

HYPERICUM PATULUM (St. John's Wort). A most desirable shrub. It has single flowers of a buttercup-yellow, produced nearly the entire summer, and thrives exceedingly well in dry ground. 2 feet, 25 e each; \$2.00 per 10

KOLREUTARIA PANICULATA. A hardy, small, round-headed tree, with fine lobed leaves and large panicles of showy golden yellow flowers, in the latter end of July: leaves change in autumn to a fine yellow. One of the most desirable trees, particularly valuable for its brilliant, golden blossoms, which are produced so late in the season, when few if any trees are in bloom. 4 to 5 feet, 40 e eaeh; $\$ 3.50$ per 10
LABURNUM, or GOLDEN CHAIN. A beautiful smallgrowing tree, with long drooping racemes of fragran yellow flowers.

4 to 5 feet, 50e eael

LARCH, EUROPEAN. A valuable timber tree; very ornamental for lawn purposes; of rapid growth.

$21 / 2$ feet, 35e eneh

LEMON VERBENA. The fragrance from the foliage of this old favorite is delightfully refreshing.

\section{IILAC}

CHARLES X. Reddish purple

2 to $21 / 2$ feet, 35 e each; $\$ 3.00$ per 10

LA TOUR D'AUVERGNE. Double. Violet purple.

2 feet, s0c caeli; $\$ 4.00$ per 10

MADAME LEMOINE. Double. White.

2 to $21 / 2$ feet, 50e each; $\$ 4.00$ per 10

MATTHEW DE DOMBASLE. Double. Mauve.

2 to $21 / 2$ feet, $50 c$ each; $\$ 4.00$ per 10

COMMON WHITE. 2 to $2 \frac{1}{2}$ feet, 35 each; $\$ 3.00$ per 10

CoMmon PURPLE. 2 to $21 / 2$ feet, 35e eneh; $\$ 3.00$ per 10

LINDEN, BROAD-LEAVED AMERICAN. The Linden is a beautiful tree; the leaves are beautiful, thus making a very 'handsome tree. They produce small, white flowers, very sweetly scented indeed.

7 to 8 feet, $\$ 1.00$ each; $\$ 8.00$ per 10

LOCUST, THOR NLESS (Bessoniana). A very ornamenta variety; it makes a beautiful umbrella-like head, and is free from thorns. Of rapid growth. 3 to 4 feet, 40 eaeh; $\$ 3.50$ per 10. 6 to 8 feet, 60 eneh; $\$ 5.00$ per 10.

LOCUST, COMMON OR BLACK. A rapid-growing tree, with spreading branches. A valuable timber tree, and used for various mechanical purposes. 3 to 4 feet, $25 \mathrm{c}$ eaeh; $\$ 2.00$ per 10 . 6 to 8 feet, 50e eaeh; $\$ 4.00$ per 10

LOCUST, PINK FLOWERING (Deenaismeana). This grand flowering deciduous shade tree produces beautiful coral-pink flowers in long grape-like clusters for a long period and is one of our handsomest trees. Of rapid growth. 3 to 4 feet, 60 eaeh; $\$ 5.00$ per 10 . 6 to 8 feet, 75 c each.

MAIDEN MAIR TREE (Sallsburia). A remarkable tree from Japan, combining in its habit characteristics of the conifer and deciduous tree. The tree is of medium size and rapid growth; beautiful fern-like foliage, in shape resembles somewhat a Maiden Hair Fern, hence the name. Rare and elegant. 3 to 4 feet, 60e eaeh

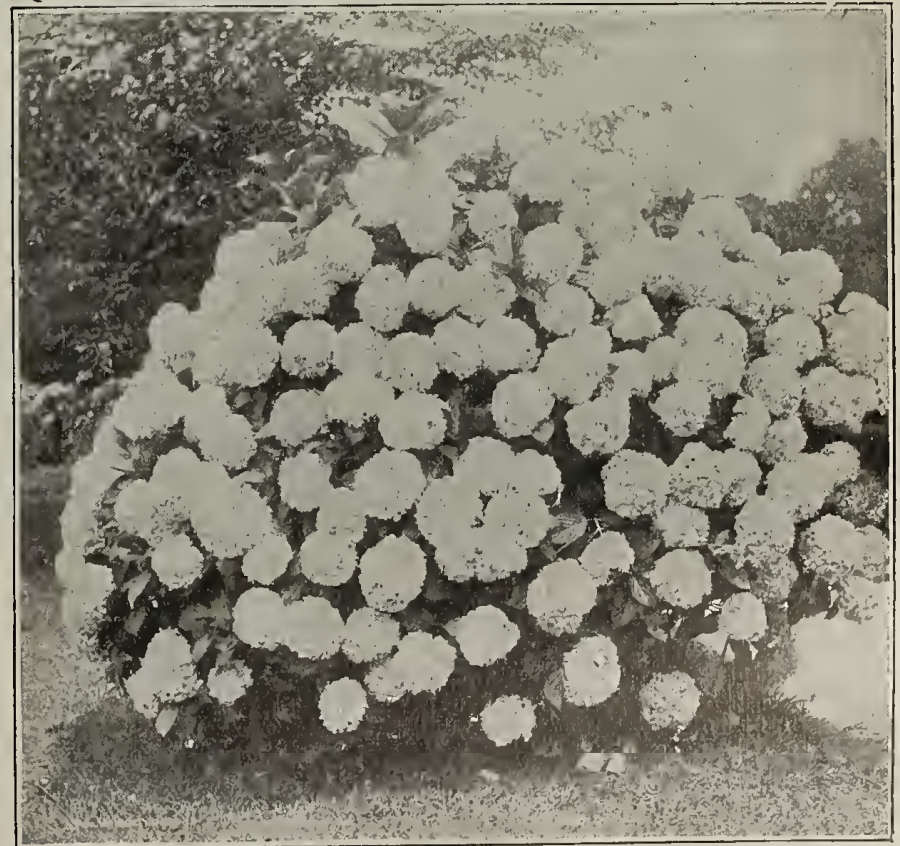

Hydrangea Panleulata Grandiflora 


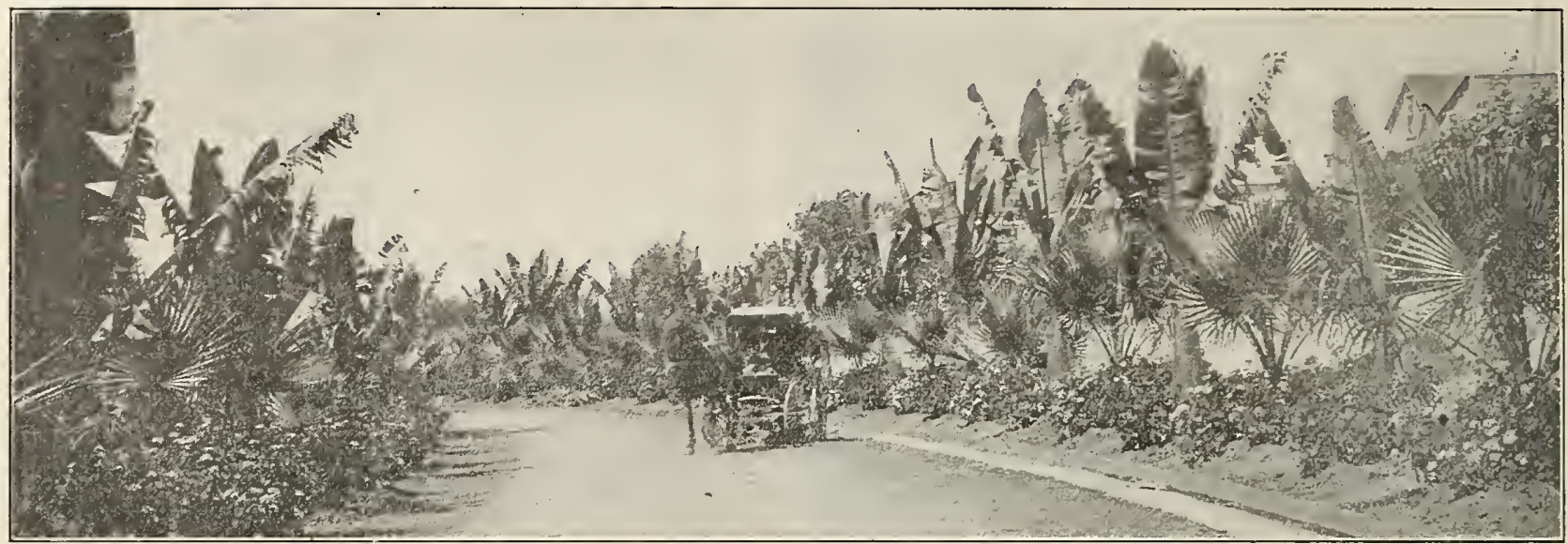

Abyssinian Bananas and California Fan Palns.

\section{MAPLE}

A valuable and highly ornamental family of trees. The Maples are regular in outline, beautiful in foliage, vigorous growers, free from all diseases, and adapted to all soils, merits which deservedly render them universally popular.

BOX ELDER. A large-growing, handsome tree, of rapid growth; foliage ash-like; a fine avenue tree.

6 to 7 feet, 60 cach; $\$ 5.00$ per 10

ENGLISH, or CORK-BARKED. A native of Europe attaining a height of sixty feet; a stocky tree, compact, roundish habit, with rough corky bark full of deep fissures. An excellent variety in the interior as it does not sunburn. 4 to 5 feet, 40 e each; $\$ 3.50$ per 10 NorWAY. A large, handsome tree, with broad, deep green foliage, and of very compact growth, rendering it one of the most desirable varieties for the street park or garden. A valuable variety in the VER, or SOFT. A rapid-growing tree of large size; irregular rounded form; follage bright green above, silvery beneath; a favorite street and park tree. A very promising and distinct tree; should be exten-
sively planted.

JAPANESE. None of our autumnal trees can excel these in gorgeousness of coloring; they include yellow, blood-red, green and variegated. The uniqueness of the shape of the leaves is also wonderful, some as delicate as the finest lace. Plant in shady place.

2 to 3 feet, 60e each; $\$ 5.00$ per 10

\section{MIAGNOLIA, JAPANESE}

These highly ornamental medium sized trees with their lavish display of fragrant many hued flowers, are worthy of a place in every garden of any size. Planted in groups, their effect in the early spring with their brilliant colorings and their rich fragrance is grand beyond description.

CONSPICUA. Flowers large, pure white, cup-shaped, very sweet. OBOVATA. Purple flowers.
S'TELCATA.
Pure white, small, star-shaped. $2 \frac{12}{2}$ to 3 feet, $50 \mathrm{c}$ each

$21 / 2$ to 3 feet, soc each

MOCK ORANGE, or SYRINGA. An invaluable shrub, of vigorous habit, very hardy, with large, handsome foliage and beautiful white flowers, produced in the
greatest profusion. MOUNTAIN ASH, EUROPEAN (Rowan Tree). Flowers creamy white; foliage somewhat like the Pepper Tree covered from August to November with large clusters of orange colored berries.

4 to 6 feet. joc each: $\$ 4.00$ per 10

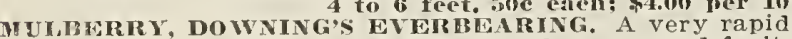
grower. A valuable shade tree; produces a good fruit.

MULBERT $Y$, WHITE. 5 to 6 fret, Goc eneh A quick-growing tree.

4 to 5 feet, 40e cach: $\$ 3.50$ per 10 OAK, ENGLISH. We take pleasure in recommending this shade tree to our customers as one of the most desir- able for California. It is of fairly rapid growth; it makes a dense head, and the leaves are a dark glossy green, to which dust does not adhere; it retains its foliage till late in the season, and sheds at a time when we do not want shade. 2 to $21 / 2$ feet, 35 c each

PEACH, FLOWERING. The double flowering varieties are distinguished for their showy and beautiful bloom. At the blossoming season in April, every branchlet is covered with a mass of beautifully formed, highly colored flowers, rendering the trees most interesting objects and attracting notice from a distance. We can supply the Double white and distance. We can supply the Double White and
Double pink.

paulo wnia IMperialis. Known as "Empress Tree." A magnificent tropical looking tree from Japan; of extremely rapid growth, and surpassing all others in the size of its leaves, which are twelve to fourteen inches in diameter. Blossoms trumpet-shaped formed in large, upright panicles and appearing in May; color a beautiful shade of lavender.

7 to 8 feet, $\$ 1.00$ each

PLUM, PURPLe-leaven (Pissardi). The young branches are very dark purple, the leaves when young are lustrous crimson, changing to a dark purple, and retain this beautiful tint till they drop late in a utumn. No other purple-leaved tree or shrub
retains its color like this. It also bears a fairly good retains its color like this. It also bears a fairly good
fruit.
$\mathbf{3}$ to 4 feet, $50 c$ each

\section{POPLAR}

Poplars are very rapid growing trees and thrive under a great variety of conditions as regards soil, but do best in damp situations and along watercourses. Their leaves are bright among other trees, of heavier foliage and give to a group a sprightly air. They are well adapted for windbreaks and are very effective when planted in groups by themselves.

"BALM OF GILEAD." Of remarkably rapid and luxuriant growth, with large glossy foliage.

6 to 8 fect, 60e ench: $\$ 5.00$ per 10 CARoliva. A very distinct tree, making a large, spreading head. Excellent for avenue planting.

6 to 8 feet, 50c each; $\$ 4.00$ per 10

LOMBARDY. This is one of the characteristic trees of parts of Italy and it is from the Italian province, Lombardy, that its common name is derived. Probably a native of Asia. A very rapid, erect striking tree with a tall spiry form and particularly strikin 6 to 8 feet, s0c each; $\$ 4.00$ per 10

PONEGRANATE, DOUBLE SCARLET. As an ornamental shrub or small tree, it is much prized in the South of Europe. This fine shrub does particularly well in California. The flowers measure two inches across, are very double and appear for a long period. This makes a very pretty hedge.

2103 feet, 35e each; $\$ 3.00$ per 10

Runce (Japanese searlet Flowering). This is the first shrub to bloom in spring and the blossoms appear in great profusion, covering every branch and branchlet before the appearance of the leaves.

2 feet, 35e ench; \$3.00 per 10 
RHUS COTINUS ("Mlst or Smoke Tree"). A low-growing, shrubby tree, covered in midsummer with large clusters of feathery flowers, giving the appearance of a cloud of smoke or mist.

3 to 4 feet, 35c each; $\$ 3.00$ per 10 RHUS GLABRA LASCINIATA ("Cut-leaved Sumach"). A very showy plant; leaves very large, deeply cut and drooping gracefully from the branches, changing to a rich red in autumn.

2 to $21 / 2$ feet, $35 \mathrm{e}$ each; $\$ 3.00$ ner 10 SNOWBALL. This well-known shrub is known to nearly everyone; they produce immense ball-shaped, white flowers in great profusion in May and June. Should be in every collection. 2 feet, 35e earh; $\$ 3.00$ per 10

\section{SPIRAEA}

A. WATERER ("Crimson Spiraea"). A valuable addition to our shrubs; the flowers are crimson, appearing in great masses. This would make a beautiful hedge; it blooms for a long period.

2 to 3 feet, $30 \mathrm{c}$ eaclr; $\$ 2.50$ per 10

DOUGLASII ROSEA. This variety has spikes of beautiful deep rose-colored flowers.

2 to 3 feet, 30e each; $\$ 2.50$ per 10

PRUNIFOLIA ("Bridal Wreath"). A beautiful sort from Japan, with pure white flowers like white daisies, produced the entire length of the branches. Certainly a magnificent sight when in bloom.

2 feet, $25 e$ each; $\$ 2.00$ per 10

THUNBERGII. Of dwarf habit and rounded, graceful form; branches slender and somewhat drooping; foliage narrow and yellowish green; flowers small, white, appearing early in spring, being one of the first Spiraeas to flower.

2 to 3 feet, $35 \mathrm{c}$ each; $\$ 3.00$ per 10 VAN HoUTter. This is the most beautiful of the early flowering Spiraeas. Similar to the Bridal Wreath more graceful in habit, and the delica with which the branches are covered in May make a most beautiful appearance. An excellent hedge can be made from this plant.

2 to 3 feet, 35c each; $\$ 3.00$ per 10
TAMARIX AFRICAN. An elegant and handsome flowering small tree, thriving in all soils and locations, whether by the seashore or hot interior valleys. The flowers are pink, appearing all along the branches; foliage feathery and graceful.

5 to 6 feet, 35c each; $\$ 3.00$ per 10

TEXAS UMBRELLA TREE. This is one of the handsomest of deciduous shade trees, and is adapted particularly to the warm parts of this State, where, when sufficient water is supplied, it assumes a grand umbrella-shaped head, affording delightful shade in the hot summer days.

3 to 5 feet, strong, 60e each; $\$ 5.00$ per 10 THORN, DOUBLE WHITE. Has small double white flowers. A highly ornamental variety, on account of both foliage and flowers.

4 to 5 feet, 60c each; $\$ 5.00$ per 10

THORN, DoUBLE PINI. Similar to the preceding in all respects but color, which is pink or rose.

4 to 5 feet, $60 \mathrm{c}$ each; $\$ 5.00$ per 10 THORN, PAUL'S DOUBLE SCARLET.

4 to 5 feet, 60c each; $\$ 5.00$ ner 10

TULIP TREE. A magnificent rapid growing tree of tall pyramidal habit, with light green, glossy, fiddleshaped leaves, and greenish yellow tulip-like flowers. Known to lumbermen as Poplar and Whitewood.

3 feet, 40c each

WALNUT, AMGRICAN BLACK. One of the best shade trees for California; of rapid growth.

3 to 4 feet, 30c each; $\$ 2.50$ per 10 WEIGELIA A. CARRIERE. Bright rose; a choice sort. WEIGELIA CANDIDA ("White Flowered weigella"). A very free flowering variety. One of the best. 2 to $21 / 2$ feet, $35 \mathrm{e}$ each; $\$ 3.00$ per 10

WEIGELIA RoseA. An elegant shrub, from Japan. They produce superb, large, trumpet-shaped flowers of a fine rose color. 2 to $21 / 2$ feet, 35e each; $\$ 3.00$ per 10

viluow, BABYLonran. This is the willow we see so many of in this State and known as "Common Willow." It is best suited to plant in wet land, where it makes rapid growth and affords grateful shade for stock, who browse lazily of the lower branches, and when so pruned add picturesqueness to our landscapes.

3 to 4 feet, 35e each; $\$ 3.00$ per 10

\section{Climbing and Trailing Plants}

Some nice, rapid-growing, climbing plants planted round our dwelling houses add considerably to the beauty thereof, be it the mansion of the opulent or the dwelling of the artisan. What dear memories cluster around the names the "Honeysuckle" and "Sweet Briar." Who does not remember the sweet fragrance of these old, old favorites, friends of long ago?

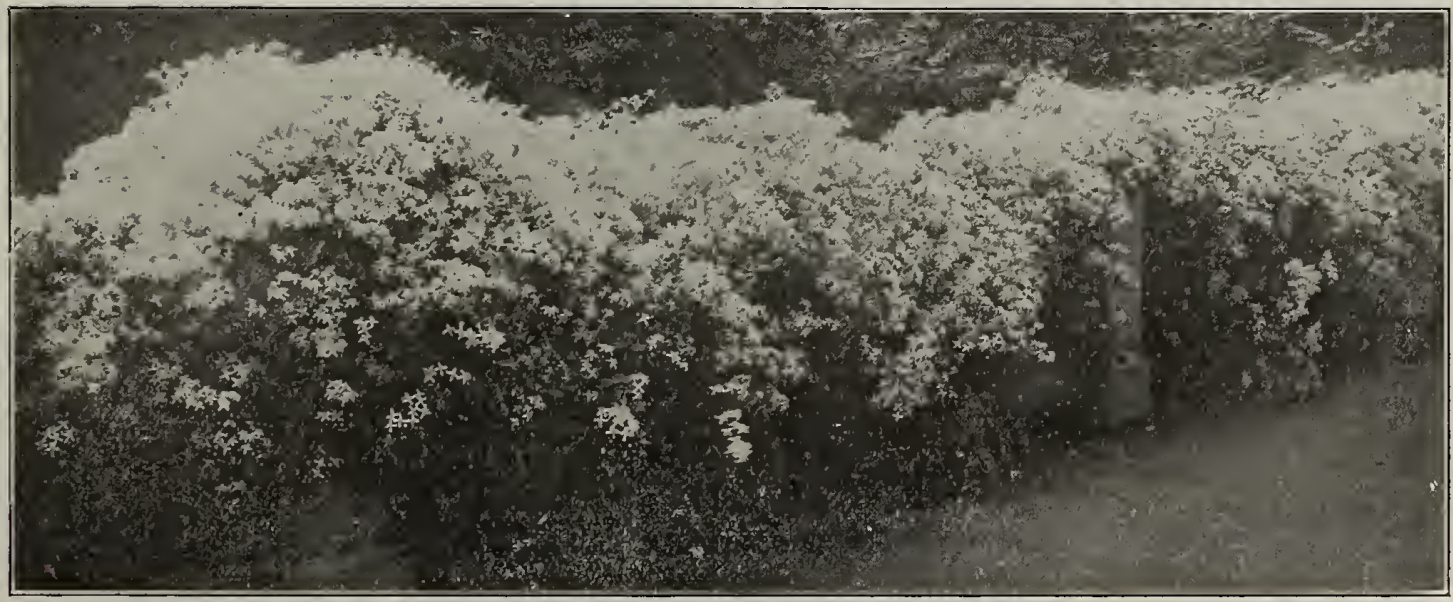

Clematis Paniculata. Note the wealth of bloom

AKEBIA QUINATA. A very distinct and pretty climber from Japan. Foliage clover-like in appearance, semievergreen; flowers chocolate-colored, appearing in early spring. Very sweet.

50e eareh

AMPELOPSIS ENGELMANNI. Shorter jointed than quinquefolia. Strong grower.

2-year-old plants, 50e each, \$4.00 per 10

AMPELOPSIS MURALLIS. Resembles the quinquefolia, but is more slender in growth and shorter jointed, with smaller foliage. 2-5ear-old plants, 50c each, $\$ 4.00$ per 10
AMPLops QuiNQUEFolia (Virginia Creeper). The leaves are palmate, handsome and luxuriant, assum ing in autumn a gorgeous bronzy hue.

Small plants, 25c each; strong, 50c each

AMPELOPSIS VEITCHII (Boston or Japan Ivy). This variety clings closely without any assistance to a stone
wall or brick flue or a wooden surface. It is widely planted in California, where it succeeds admirably, and is much admired.

Strong plants, 50c each; $\$ 4.00$ per 10 AUSTRALIA PEA VINE. Pink flowers; fast growing. 
CLIMBING AND TRAILING PLANTS-Continued

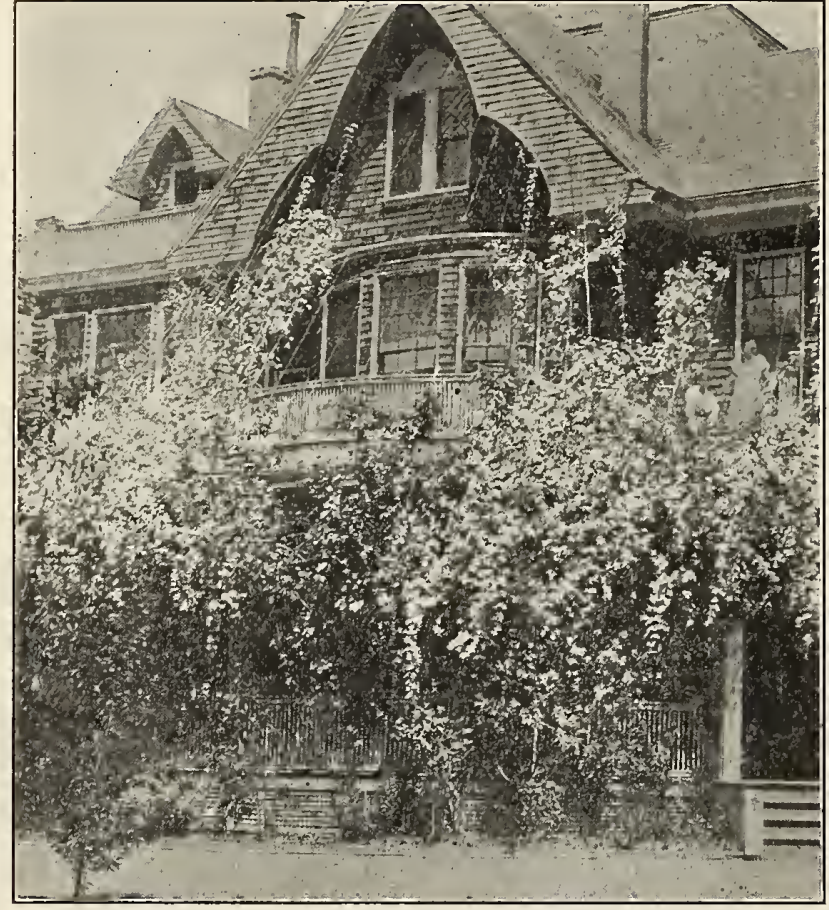

Clematis Montana

Photo C. C. Morse \& Co.

\section{CLEMATIS}

The Clematis are elegant, slender-branched climbers of rapid growth, with fine foliage and beautiful, large flowers of various colors; they are perfectly hardy, and cannot be excelled as climbing plants in any situation; they are very particular as to soil, that of a loamy texture being the most suitable; thorough drainage is indispensable to good, healthy growth; large, deep holes should be dug, and if the soil is heavy it must be replaced; in planting, the roots should all be spread out, and plants pruned down to one-half their height; they should never be allowed to get very dry; an annual manuring should be given, and tops pruned off in December. $75 c$ each, except where noted.

BARON DE VIGLLARD. Pale lavender; large single. DUCHES OF EDINBURGH. Fine large double white; sweetly scented.

FAIRY QUEEN. Pale flesh, with striking pink bar; large single.

JACKMANII. Deep purple violet, produced in masses; one of the best; large single.

JACKMANII ALBA. Blush, changing to white; same habit as Jackmanii; large single.

IERMESTNA. Brilliant red; large single.

LAWSONIANA. Rosy purple; very large single.

MISS RATEMAN. White, red anthers; large single.

MONTANA. In this variety we have the ideal Clematis for this State. The flowers are produced in spring in wonderful profusion (as will be seen from the picture which we have pleasure in presenting); they are about the size of dollar and are pure white. The vine is a rapid, rampant grower.

Strong plants, 60e each

NELLY MOSER. Light mauve, with red bar; large single.
PANICULATA. A Japanese climber, recently introduced into this country, of unusual and attractive merits: rapid grower; foliage of a glossy rich green; the flowers are of medium delicious fragrance.

PRESIDENT. Bright blue; large single.

PROTEUS. Rose, shaded flesh color; large single.

SIEBOLDII. Large single lavender.

STELLA. Light violet; large single

VILLE DE LYON. A fine new red variety; large single.

BOUGAINVILLEA SPECTABALIS. These climbers are becoming greater favorites every year. They have peculiarly shaped flowers, pecou produced at the end of the branches in wonderful profusion. They are indispensable for the greenhouse and do remarkably well in many protected situations out of doors. Strong plants, 60c each

BIGNONIA GRANDIFLORA (Trumpet Vine). Rapidgrowing climber, bearing large orange-yellow trumpet-shaped flowers in great profusion.

Strons plants, 50e each ingly showy. BIGNONIA VENUSTA. A vigorous grower, producing large, deep, orange-colored flowers.

FICUS REPENS. A very pretty useful climber; clings to stone, brick or wood; like the Boston Ivy Evergreen.

HONEYSUCKLE, BELGIAN OR ENGLISH. Red and yellow flowers; long bloomer; very fragrant. $40 \mathrm{c}$ each

HONEYSUCKLE, GOLD NETTED. A beautiful variety: the leaves are veined golden yellow. 35e each

HONEYSUCKLE, HALLEANA, HALL'S JAPAN HONEY SUCKLE. A strong, vigorous, almost evergreen sort, with pure white flowers, changing to yellow; very fragrant; a long and continuous bloomer. $40 \mathrm{c}$ each

HONEYSUCKLE PUNICEA. A most beautiful sort; having scarlet triumpet shaped flowers.

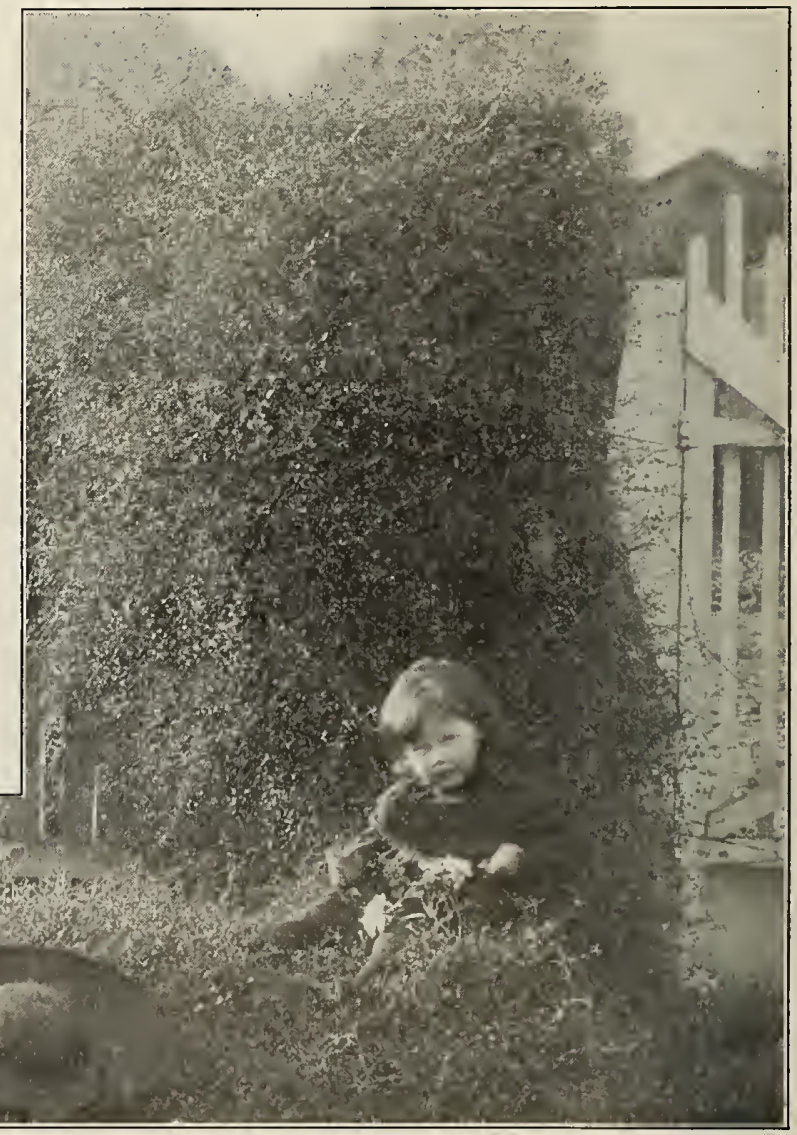

Muehlenbeekia-New Zenland Mattress Vine Photo C. C. Morse \& Co. 
HoPS (Humulus Lupulus). One of the very best climbers for covering unsightly places. It is a rapid grower, and bears a profusion of seed-pods suitable for many domestic purposes.

March dellvery s0e per dozen (60c postpald).

IVY, ENGLISH, LARGE-LEAVED. Leaves thick, shining, leathery.

$25 \mathrm{c}$ each

IVY, WNGLISH, SYALL-LEAVED. Large plants, 50c each IVY, VARIEGATED, SILVER-LEAVED.

Large plants, 50c each

JASMINE GRANDIFLORUM (Catalonlan Jasmine). Plant is of shrubby, half-climbing habit, with very delicate foliage, and its small, white, star-shaped, fragrant flowers are produced in the greatest profusion rant the year round.

JASMINE REVOLUTUM (Yellow-Flowering Jasmine). Produces fragrant yellow flowers. 35c each

JASMINE OFFICINALIS. Flowers pure white, sweetlyscented, produced in early spring.

MUEHLENBECKIA COMPLEXA (New Zealand Mattress Vine). This pretty, strong-growing climber and trailer is very desirable for covering old stumps of trees, rockwork, etc. The foliage is small, dense and graceful.

40e each

PASSION VINe (Passiflora). These well-known hardy climbers are familiar to and appreciated by all They are of rapid growth, and very attractive when covered with their large handsome flowers.

PASSION VINE, PINK.
PASSION VINE, SCARLET. Strong plants, 50c each PLUMBAGo CAPENSIS. Can be trained as a bush or climber. Flowers light sky-blue, verbena-shaped, produced throughout the entire summer; stands drought and water and the brightest sunshine.

35c each

SMILAX.

20c cach; 3 for 50c

SOLANUM JASUINOIDES GRANDIFLORA. A most beautiful climber. Its flowers are star-shaped, and borne in good-sized panicles or clusters.

25 e each

TECOMA JASMINOIDES. An evergreen climber, with bright glossy foliage; flowers white, with beautiful blotch of lavender; fowers large, bell-shaped appearing in clusters. Hardy only in sheltered situations. 4-inch pots, 50c each

VINCA-PERIWINTLE. Very useful for rockwork or covering trees and banks.

10e each, 75e per 10, \$5.00 per 100

WISTARIA SINENSIS (Chinese Wlstaria). One of the most elegant and rapid growing of all climbing plants; attains an immense size, growing at the rate of 15 to 20 feet in a season. Has long, pendulous clusters of pale blue flowers in May. 50e and $\$ 1.00$ each

Wistaria SINENSIS ALBA (Chinese White Wistaria). Pure white flowers. Introduced by Mr. Fortune, from China, and regarded as one of his greatest acquisitions.

WISTARIA SINENSIS ROSEA. A fine new variety with clusters of pink flowers. $\$ 1.25$ each

\section{Palms, Dracænas, Etc.}

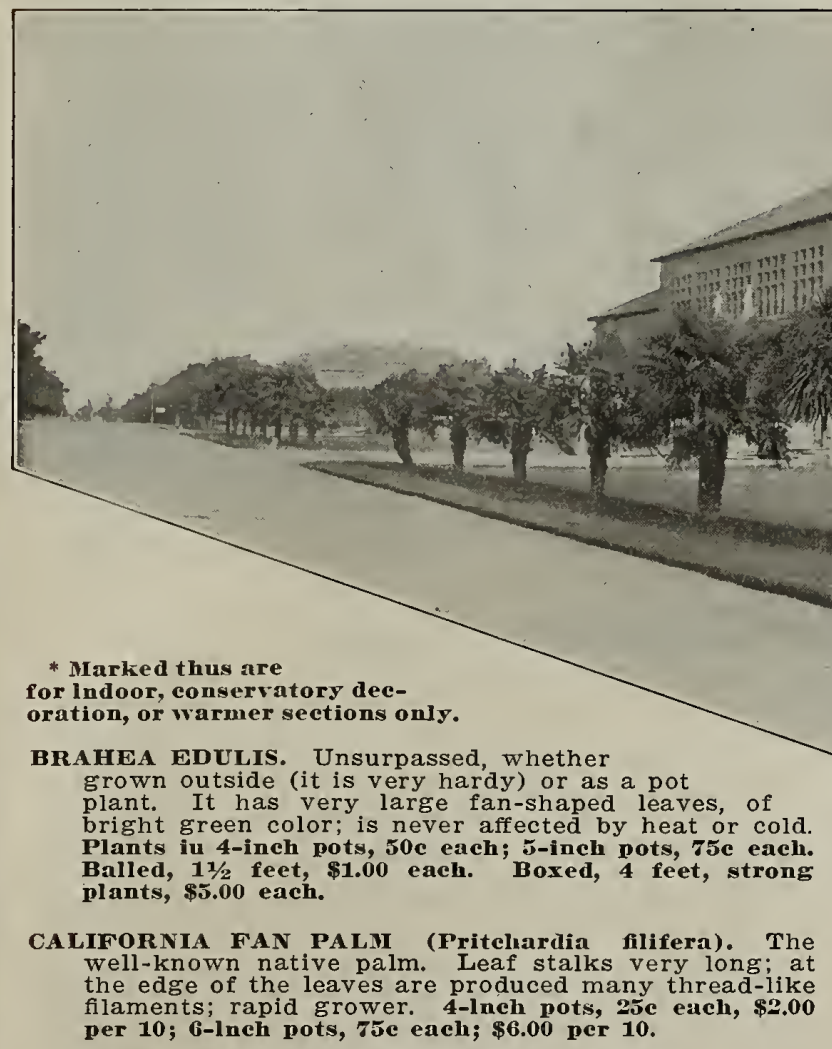

CHAMAEROPS EXCELSA (Japanese Fan Palm). One of the hardiest of the Fan Palms. Foliage dark green; the segments of the fan-shaped leaves deeply cut, the edges covered with tooth-like spines. Grows from 15 to 20 feet high; very desirable for sidewalk decoration. Balled, $21 / 2$ feet, $\$ 2.50$ each; $31 / 2$ fect, $\$ 3.50$ each

*CORPYHA AUSTRALIS (Livlstonia). An Australian palm. Foliage dark green; very symmetrically and regularly slit, the segments partially doubled from base of petioles or leaf stalk, which is thickly armed with crooked spines. Used chiefly for house decoration, though hardy in some locations.

4-inch pots, 50c each; 5-inch pots, 75e each
*CYCAS REVOLUTA.

The well-known "Sago

Palm" so much in demand for

inside decoration. The stems are

cylindrical, terminating in a crown of handsome, feather-shaped leaves of thick, leathery texture. In the southern part of this state this ve riety grows to perfection out of doors. $75 \mathrm{c}, \$ 1.00$ $\$ 1.50, \$ 2.00, \$ 3.00$ and $\$ 5.00$ each, according to size.

Cocos plumosus. Hardy in some localities, and when grown outside is of rapid growth. No handsomer

DRACAENA INDIVISA. A fine plant for outdoor planting in California, and much in use for lawns, avenues and parks. The small plants are fine for window decoration. 4-inch pots, 35e each; $\$ 3.00$ per $10 ;$ balled,
$21 / 2$ feet, $\$ 1.00$ each, $\$ 5.00$ per $10 ;$ balled, 3 feet, $\$ 1.50$ 


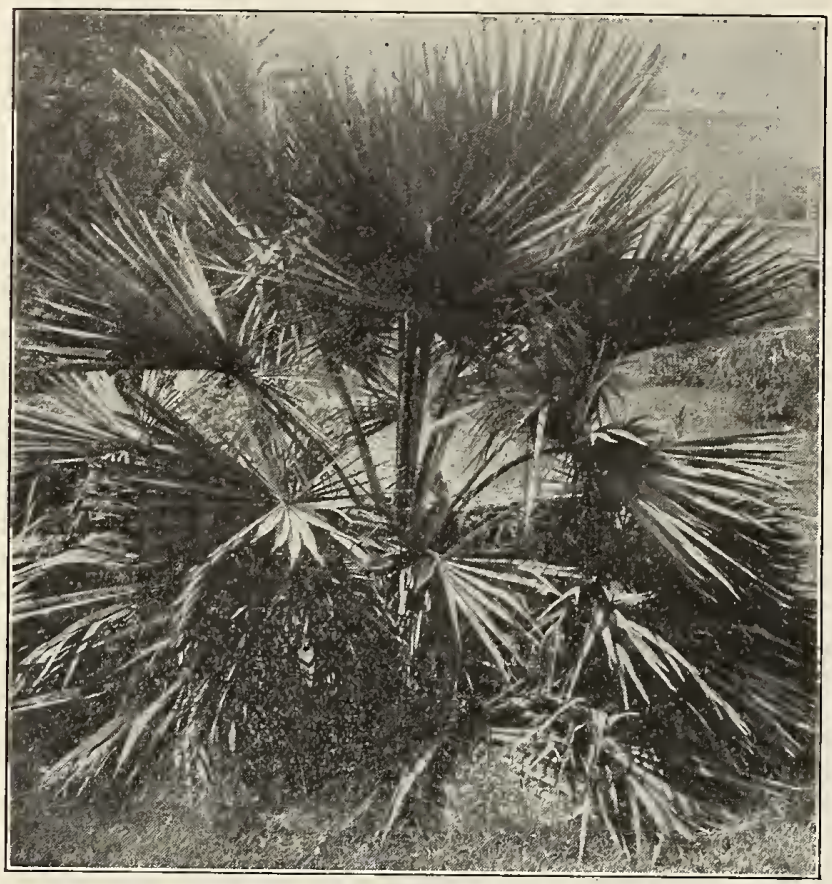

Brahear edulis

Photo C. C. Morse \& Co.

EULALIA GRACILIMA. The foliage is narrow, long and graceful; much used on lawns, where, when supplied liberally with water, it produces a grand effect. Goe each

* KENTIA BELMOREANA. This fine palm is a valuable addition to our collection. Its leaves are pinnate, dark green, and so beautifully crisp as to gain for it the name of "Curly Palm." It is very elegant and graceful in habit. A native of Lord Howe's Island, where it attains a height of 40 feet. Plants in 3 -inch pots, 35e each; in 4-iueh pots, 50e and $75 e$ each; in 5 -inch pots, $\$ 1.25$ each; 6 -ineh pots, $\$ 1.50$ each.

* KENTIA FOSTERIANA. One of the finest of the Kentias, with graceful, bright green foliage. Plants in 3-inch pots, 35e each; in 4-inch pots, 50e and $75 \mathrm{c}$ each; in J-inch pots, \$1.25 each; in 6 -inch pots, $\$ 1.50$ each.

* LATA NIA BORBONICA. Leaves large, fan-shaped, of a very cheerful green color plant of hardy construction, and adapted to all decorative purposes within doors. Appreciated by all the plant-loving comdoors. Appreciated by all the plant-loving com-
munity. Nice Joung plants, 35e each; larger plants, $\$ 1.00$ each.

IUSA ENSETE (Abyssinian Banana). The noblest of all plants is the great Abyssinian Banana. The fruit of this variety is not edible, but the leaves are magnificent, long, broad, and massive, of a beautiful green, with a broad crimson midrib. The plant grows luxuriantly. riantiy, from attains gigantic proportions, producing a tropical
effect in one season.

PHOENIX CANARIENSIS (The Canary Island Date). The handsomest and hardiest species of the date palm family. Being a rapid grower, it soon develops into beautiful specimens, with pinnate, dark green leaves, from 6 to 12 feet long, the divisions linear, lanceshaped, very much pointed. It is fully as hardy as shaped, very much pointed. It is fully as hardy as that variety in its habit of growth, color, and style that variety in its habit of growth, color, and style of foliage, a finer contrast cannot readily be imag-
ined when the two are planted, either opposite or alternately in rows. Balled, $11 / 2$ to 2 feet, \$2.00 each in boxes, $21 / 2$ feet, $\$ 3.00$ each; $12-i n c h$ pots, 3 feet, select specimens, $\$ 4.00$ each.

PHOENIX DACTYLIFERA. Produces the date of commerce.

Boxed, 3 feet, $\$ 4.00$ each

PAMPAS GRASS.

Strong elumps, 60e each

* APHIS HUMLIS. China and Japan. A hardy little cane palm, which suckers from the roots like the bamboo and forms a dense clump of canes. A delicate and graceful little plant, only 3 to 4 feet in height when full grown.

Strong plants in 8 -inch pots, $\$ 4.00$ each

* SEAFORTHIA ELEGA NS. Leaves dark green; the leafstems rather stout at their base, pinnate, lanceolate and narrow bifid at the apex; the whole plant perfectly smooth on a cylindrical smooth whitish-green stem. In the southern part of the State this variety is hardy; very handsome.

Plants in 5-inch pots, 60e each

rRitoma UVARIA (Red-Hot Poker Plant). So called on account of its scarlet flowers resembling that household article. They are borne on long stiff stems during summer months, and are very effective.

Clumps, 35e each

IVASHINGTONIA ROBUSTA. One of the hardiest and most beautiful of palms; in habit of growth resembling our well-known California Fan Palm but more symmetrical and spreading; leaves fan-shaped, medium size, retaining their dark-green color during dium size, retaining their dark-green color during
the winter months; stems short, thorny; of upright, compact growth.

\section{Conservatory and Parlor Decorative Plants}

Under this heading we have included such plants as flourish in the parlor, hall, greenhouse, and some in protected situations out of doors.

ASPARAGUS DECUMBEvs A variety of most beautiful appearance. PARAGUS PLUMosus. The leaves are a bright green, are gracefully arched, and are as finely woven as the finest silken mesh, surpassing Maiden-Hair Ferns in grace, fineness of texture, and richness of color. 25e, 35e and 50e, aceording to size

ASPARAGUS SPRENGRRII. A variety of recent introduction. It is as a basket plant that this will prove most valuable. In S-inch pans, $75 e$ each; in hanging baskets, $\$ 2.00$ each.

ANTHERICUM VARIEGATUM. Foliage beautifully striped yellowish white; succeeds admirably in the window; also much esteemed as a basket plant.

4-inch pots, 35e each

ASPIDISTRA LURIDA. This is the plant one sees so many of in windows, halls, and stores. The foliage

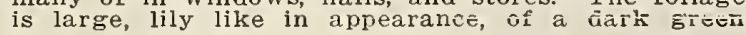

color. It is of rugged constitution and will stand in locations that would kill most plants.

75e, $\$ 2.00$ and $\$ 3.00$ each, recording to size.

ASPIDISTRA LURIDA VARIEGATA. A variegated form of the preceding.

Large plants, in 7 and 8 -inch pots, $\$ 2.50$ and $\$ 3.50$ each Colwus. Ready in April.

$15 \mathrm{c}$ and $25 \mathrm{c}$ each

CYCLAMEN. Charming plants, with beautiful foliage and richly-colored fragrant flowers. Universal favorites for winter and spring blooming.

Pot grown plants, in leaf and bloom, 35e each

FICUS ELAstica (India Rubber Plant). Very large, smooth, leathery leaves, evergreen foliage; generally esteemed one of the finest house plants grown, the plant attaining a large size. 50e, 75e, \$1.00, \$1.50 each

ISOLEPIS GRACILIS. A pretty grass-like plant, valuable for hanging-baskets and decorating the edges of benches in greenhouses. 4 -inch pots, ase each

Dear Sirs-The first consignment of Loganberries are to hand today, and have arrived in excellent condition. I hope that you have sent the remainder. The packing of this consignment is excellent and cannot be improved on. Please keep this for future reference and pack all future consignments the same way. Yours faithfully, W. C. Slocock, Woking, Surrey, England. 


\section{Select List of Ferns}

ADIANTUM CUNEATUM (Maden-Haix Fern). This fine variety is more generally grown than any of the other sorts; for cutting, greenhouse, and parlor decoration. 5 -inel pots, $50 \mathrm{c}$ each: 6 and 7 -ineh pots, 75 each; in hanging baskets, $\$ 1.50, \$ 2.50$ and $\$ 3.50$ each

ADIANTUM GRACILIMUM. A variety that has finer and mole graceful foliage than the preceding; a most lovely sort. 5-ineh pots, 50e each; in hanging baske1s, $\$ 2.00$ and $\$ 2.50$ each.

ADIANTUM PEDATUM. 4-inch pots, 35e each

ASPLENIUM FALCATUM (Holly Fern). A favorite variety for house culture; the leaves are dark and very glossy and the fronds beautifully arched.

3-inch pots, 25e each

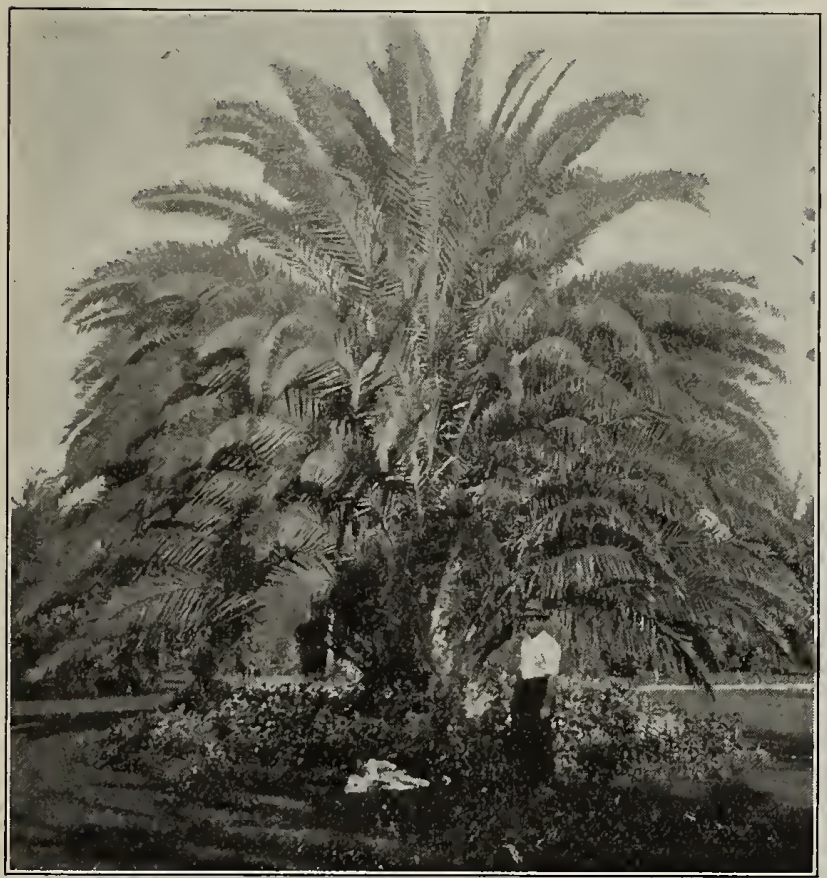

Phoenix Canariensis

Photo C. C. Morse \& Co.
ASPLENIUM NIDUS AVIS (Bird's-Nest Fern). The fronds of these curious looking ferns are long and broad, with a dark colored midrib; the fronds in time attain a growth of. 7 or 8 feet, very dense, and in the center there is a hairy growth, and as one looks down into it it resembles a bird's-nest; hence the name. 3-inch pots, 50e each

ALSOPHYLLA AUSTRALIS (Australian Tree Fern). A most useful fern for house decoration; of easy cul-

JAPANESE FERN HANGING BALLS. FOe each

NEPHROLEPIS BOSTONIENSIS (Boston Fern), Is one of the very few plants that will thrive under ordinary house care. It grows well, and improves in size where most all other ferns fail. The fronds droop and arch gracefully over the edge of a pot or basket, and, as it is a very rapid grower, it is not long before they reach the floor from an ordinary parlor table.

35 each

NEPHROLEPIS FXALTATA (Sword Fern). Splendid extra hardy sort, well adapted for house culture, succeeding, with ordinary care, with every one who tries it.

50e and $75 \mathrm{c}$ each

NEPHROLEPIS ELEGANTISSIMA. This fern has lovely plume-like foliage and is in much demand for house or greenhouse decoration; of recent introduction.

A-ineh pots, $40 \mathrm{c}$ ench

NEPHROLEPIS WHITMANII. This is one of the newest introductions to the "plume foliage" varieties and it is certainly very fine; must be seen to be appreciated. Does beautifully in hanging baskets.

POLYSTICHUM SETOSUM. In hanging baskets, \$2.50 each PTERIS ARGYRFA. Fronds prettily striped silvery white. 4-inch pots, 35e each

PTERIS ADIANTOIDES. Fronds similar to those of the Maiden-Hair Fern, only larger; very nice.

4-inch pots, 35e each

PTERIS DRINIKWATERII. Silvery green foliage; vecy choice.

PTERIS HASTATA. Broad fronds; very showy. and arching. $\quad$ 4-inch pots, 3Je eaeh

PTERIS WINSETTI. A beautiful sort, with lovely crest ed foliage.

4-ineh pots, 35e each

TREE FERN, NEW ZEALAND (Dieksonia antartica). We have always been large importers of this truly grand Tree Fern, and the ever-increasing demand has compelled us to keep up with the times; so we have a good assortment of well-established plants to offer grom \$5.00 to \$25.00, wecording to plants to offer from \$5.00 to \$25.00, aceording to size. For greenbe beaten; or for outside work, when planted in a sheltered location, they are also very suitable.

\section{The Dahlia}

Of late years these have sprung into wonderful prominence, and are becoming more and more popular every year. This is not to be wondered at, considering how they have been improved upon. The Cactus Dahlia of today is much superior to the old "show" round stiff sorts (though still admired by many) of old. The Cactus varieties have long twisted petals, resembling in many cases chrysanthemums.

CULTIVATION.- While the Dahlia is one of the easiest of all flowers to cultivate, it by no means follows that it requires no attention. In fact, no flower that we have ever cultivated will give such a generous response to good cultivation as the Dahlia. Deep and thorough stirring of the soil during the early growth of the plant is indispensable to success. With poor cultivation or neglect, the flower will rapidly degenerate-becoming semi- double and faded in color. The Dahlia, with but few exceptions, should be given an open, sunny situation for at least a portion of each day. It is a rank feeder and should be given rich soil and kept free from weeds. We are in favor of taking up the roots every year, as soon as the tops are cut down by the frost, and laid away in sawdust or in a dry place. Plant them out again in MAY OR THEY CAN BE PLANTED AS LATE AS THE END OF JUNE. We strongly advise our customers not to be in a hurry about setting the Dahlia out, as it is essentially a fall flower, and when planted early they bloom in the hot summer months, and the flowers are very inferior, and at that season they are generally infected with an insect called "Diabrotica," resembling a lady bug, which does much damage to the flower of the Dahlia. This insect disappears later on; hence our reason for advising late planting. So many of our customers have been disappointed in this respect just through early planting. Continuing with our remarks about cultivating, as soon as the plants are about two feet high, they should be staked, care being taken that the stake is driven far enough away from the root, so that it may not be injured. Mulch heavily with old, well-rotted manure, and give the plants a thorough soaking once in ten days or two weeks. Frequent syringing adds greatly to the health and vigor of the plant. Disbudding or picking off some of the flower buds and leaving only a few on one bush adds greatly to the size of the bloom. Dahlias can be set out from two kinds of roots, viz., DRY ROOTS and GREEN POT PLANTS. The former can be obtained as suon as we dig them, in December, and can be kept in sawdust, as above described, till planting time. It is better to order early or when you are getting your other stock. 


\section{DAHLIAS-Continued}

GREEN POT PLANTS will be ready for delivery during May; they are grown in pots and raised from a cutting. There are some of the newer sorts which we can supply in green plants only. These-green plants-you will please remember, will all bloom the first season after planting, and at the same time they are forming a bulb, which will do for planting out next season. THE DAHLIA KEEPS ON MULTIPLYING YEAR AFTER YEAR.

\section{NEW CHOICE CACTUS DAHIIAS}

We will supply dry roots of the following varieties, as long as they last; after they are sold out we will supply green plants, those are ready during May. Those sorts marked with an asterisk we can supply in green plants only. Price, 35c each; $\$ 3.50$ per dozen.

*ALBION. Pure white Cactus; the petals are very large and of true cactus form. It is a constant bloomer; the stems are long and stiff.

CHARM. The base of the petals yellow, varying to red, with white tips and edges; very full in bloom. Distinct and charming.

COMET. A grand "fancy cactus," which has proven most satisfactory with us. The ground color is silvery rose, speckled and striped crimson. The stems are long and stiff and the flowers are borne well above the foliage; a good bloomer and keeper.

EVA. Pure white; petals incurved; an exceedingly free bloomer; flowers of medium size and fine form; of dwarf habit.

FLAMINGo. Very bright scarlet; flowers large, long pointed petals; stems strong, throwing the flowers well above the foliage; extremely profuse in bloom.

FLORIDORA. Dark velvety crimson. Plant of medium height, branching in habit and an exceedingly early and profuse bloomer; continually in bloom. Fine for cutting, as the flowers are borne on long, erect stems, and keep for a long time.
MAD. H. CHANET. Pure snow-white; flowers of uncommon shape, being somewhat on the decorative type, looks more like a white water lily than a dahlia. Of free growth and prolific in bloom and of very large size.

* Mrs. H. J. JoNEs. Scarlet, edged cream and heavily tipped with white, very large and perfect; fine erect habit, blooms well above the foliage; one of the best, most distinct, and valuable of the parti-colored varleties.

PRoFEssor ZACHARIAS. Canary yellow; long pointed petals; very free in bloom, the bushes being literally covered with a mass of flowers.

*RICHARD DEAN. One of the most striking novelties of the year. Vermilion scarlet, with distinct white tips. The habit will please the most exacting. It is upright, and flower stems of great length. Flowers are of good size and splendid form.

SPOTLESS QUEEN. A grand Cactus Dahlia, pure white; stems long and stiff.

*SYLPH. Rich golden-yellow; petals long and narrow, double to center. Free and constant in bloom; stems good. A highly commendable sort.

*VESUVIUS. A fancy cactus sort, much admired; the ground coloring is cinnamon-yellow, and penciled scarlet; petals long and full to center.

VICTOR VON SCHEFFEL. In this new soft pink cactus Dahlia, we have a decided acquisition; petals narrow and pointed. It is a strong vigorous grower, extremely profuse bloomer with long, erect stems.

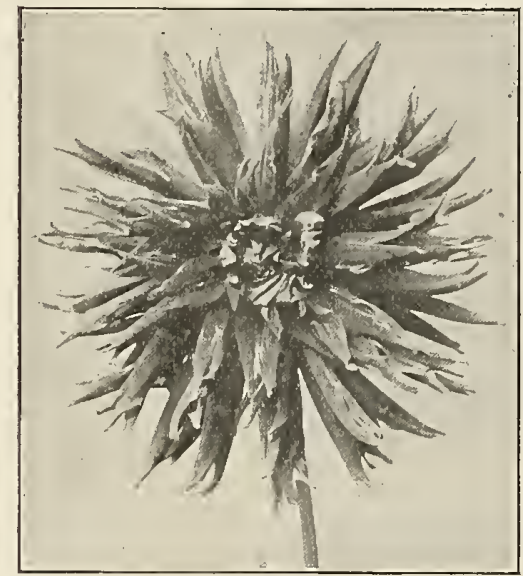

Progeniture

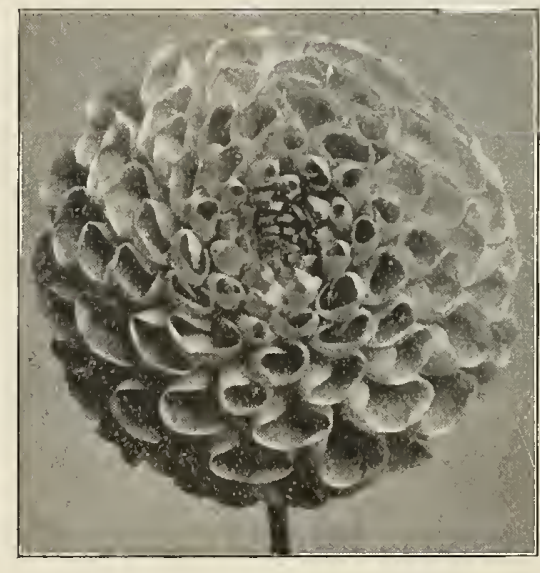

A. D. Livoni1

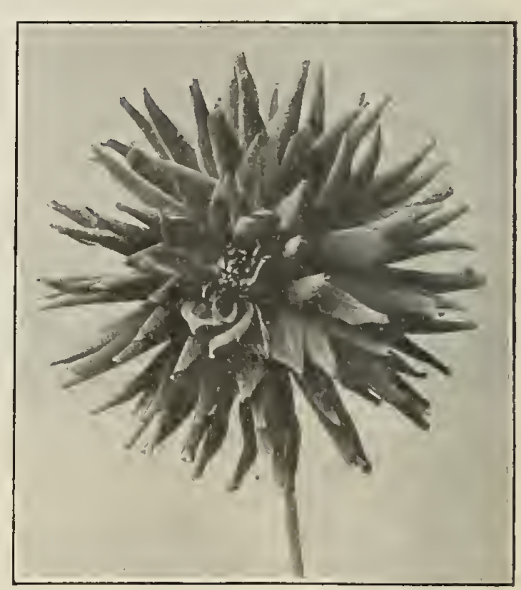

Countess of Lonsdale
* FLoRence. A charming shade of yellowish orange. The flowers last well, and always come good from early to late. The pointed petals are arranged neatly; very free in bloom.

F. H. CHAPMAN. Yellow overlaid with deep orange; very bright and effective. A flower of grand form and largest size, with narrow, beautifully incurved petals.

GENERAL BULLER. Rich velvety crimson, nearly black at the base, each floret having a pure white tip, those in the extreme center showing a tinge of plum those in the extremernable and perfectly distinct flower. Long erect stems, very free.

*GENESTA. The ground color is amber, passing towards the center to golden-yellow; the florets are beautifully arranged. Good free bloomer; stems long and erect.

GOLDFINCH. Clear bright cinnamon; the best of this shade; petals gracefully incurved.

J. C. JACKSon. The deepest, darkest velvety maroonblack; of true cactus form; fine stems; grand bloom-
er. Nothing to equal it in its color. Perfection. KREMHILDE. Delicate shell-pink with white at center; of good cactus form; a free and long bloomer.

MAID OF HONOR. Rosy pink. A magnificent large flower with long narrow petals; exceedingly free in bloom. The stems are all that can be desired.
WINSOME. A very fine white cactus dahlia; flowers very large, beautiful cactus form, with twisted, incurved petals, and borne on long, erect stems, holding the flowers well above the foliage.

\section{ALBERT ELDRED}

\section{The Newest Fancy Dahlia}

It gives us much pleasure to offer this grand, new acquisition. This variety was raised by Wm. Eldred, Burlingame, California. The ground coloring is a most lovely shade of orange-pink, the end of the petals are beautifully tipped with white, altogether a most wondrous color, which we are unable to adequately describe as it should be; suffice it to say that those ordering this variety cannot but be delighted with it. The formation of the flover is also very fine, being absolutely faultless. The flower when grown to perfection, is very large. We have a limited number of dry roots to offer at 50e each, and later on we will have green pot plants for sale at the same price.

\section{TWO NEW DECORATIVE DAHLIAS} $35 \mathrm{c}$ each.

*DIr. GATES. Soft velvety white, tinged pink; a novel and exquisite shade; an abundant and pood a novel * SANTA CrUz. Straw-yellow; petals tipped rosy pink; a charming color. 


\section{SOIME OF THE BEST OF THE OLDER CACTUS DAHLIAS}

25c each; $\$ 2.50$ per dozen. Those marked with an asterisk, green plants only.

BEAUTX OF NIGHT, An intense dark, velvety black. The petals are long, pointed and twisted; stems long The petals are long, pointed and twisted; stems long very free in bloom.

BRITANNIA. Delicate shade of soft salmon pink, blended with apricot. Petals long and twisted. Very full in bloom; stems long and stiff. Superb.

COUNTESS OF LONSDALE. A most beautiful Cactus Dahlia of true type. Color rich salmon tinted with apricot at the base of the petals, carmine pink towards the tips; stems long and stiff; very free in bloom. Hard to beat.

GREEN'S WHITE. White, with yellowish center; good free bloomer.

HOHENZOLLERN. Buff-orange; petals much twisted and pointed. Very desirable.

*INNOVATION. Reddish scarlet, ends of petals distinctly tipped with white. Very fine and much admired.

J. W. BAGGE. Color bright radiant orange, with a tint of shining vermillion, an indescribably beautiful shade; flowers extremely large; stems long; blooming qualities unexcelled.

MATCHLESS. Dark purple maroon; almost same shade as the "Black Prince" rose. In form, color, size, and growth this variety is perfect. Blooms for a long period.

MONARCH. The color is a rich glowing velvety crimson; stems very long and stout, and hold the flowers well above the foliage. Very floriferous indeed.

MONARCH II. This is a sport of the preceding; the plant is of dwarf habit, and is somewhat on the decorative type; color dazzling magenta; very free in bloom.

MIRS. MAWLEY. The finest yellow Cactus Dahlia of largest size, coming on strong stems; fine form and shape; every bloom coming perfect; deep canary-yellow. Superior to all other yellow sorts.

MRS. SANDERS. A beautiful deep golden-yellow; grand flowers, borne well above rich follage, on long, stiff stems. One that we can highly recommend to all Dahlia lovers.

MAJOR TUPPENNY. Center of the petals yellow-tipped and bordered with dark buff, beautifully blended; stems long and strong, carried well above the foliage: a good keeper. A novel color.

oCTOPUS. White, tinted blush, very large; good shape, free bloomer; good stems and an excellent keeper.

PRINCE OF YELLOWS. Another grand yellow Cactus; not as many-petaled as Mrs. Mawley; stems long and stout; a grand keeper.

PROGENITURE. The finest red Cactus Dahlia yet produced. Intense dark, cardinal-red; large size; heavy the whole plant is covered with blooms; petals are beautifully quilled, ends cleft or prettily fimbriated. A unique variety that should be in every garden.

RADIANCE. Soft vermilion-scarlet; shining with a gloss that illuminates the blooms; true cactus form. Good in every way. A brilliant variety that must be seen to be appreciated.

RUBY. Intense ruby-red; tip of petals touched with magenta; petals quilled and pointed; the blossoms come on good stout stems, llolding them well above the foliage.

STANDARD BEARER. We have grown this variety at our nursery for the last three years, and find it to be one of the finest scarlet Cactus Dahlias in existence. Petals are long, twisted, and beautifully quilled; color intense scarlet, never fading; flowers borne on long, intense, scarlet, never fading; flowers borne on long,
stiff stems, and well above the foliage. It is a constiff stems, and

WM. JOWETT. Deep cardinal red; perfect Cactus form, every petal quilled, very large; stems all that can be desired; very free in bloom.

\section{DECORATIVE DAHLIAS}

These sorts are more uniform in shape than the "Cactus." 25e each; \$2.50 per dozen.

AMERICAN FLAG. Bright, orange, sometimes tipped white. Much admired. Free bloomer.

COUNTES OF PEMBRoKe. Perfect form and double to the center. Color rosy lavender, beautiful shade. A magnificent sort.

FRANK L. BASSETT. Bright royal purple, shading to blue. The nearest approach to a blue Dahlia yet produced; the flowers are large, of fine form, and, full to the center until the last.
MRS. ROOSEVELT. One of the finest novelties that has been offered in years. It is of immense size, 6 to 7 inches in diameter; something of the form of Grand Duke Alexis but not so stiff and heavy. The color is a delicate blush pink. The plant is very strong, vigorous, growing about 5 feet high; of branching habit, and for such a large flower an extremely profuse bloomer.

MRS. WINTERS. Color pure waxy white, which shows no tint of variation even in the strongest sunlight It blooms very freely, producing flowers from 5 to inches in diameter.

PATRICK HENRY. Pure white; of good decorative shape; stems long and stout; very full in bloom.

\section{SHOW AND FANCY DAHLIAS}

These are the old style of Double Dahlias much im proved. Shape of the flowers in this class are mostly ball-shaped. All of them of wonderful formation.

Those varieties marked with an asterisk, green plants only. 25c each; \$2.50 per dozen.

A. D. LIVonII. A clear deep rose. The flower is well built up in the center; petals beautifully quilled.

ADMIRAL SCHLEY. A seedling of American Flag and a great improvement on that popular variety. It is of same color and marking-bright crimson with a broad white stripe through the center of each petal - but much larger and fully as profuse a bloomer.

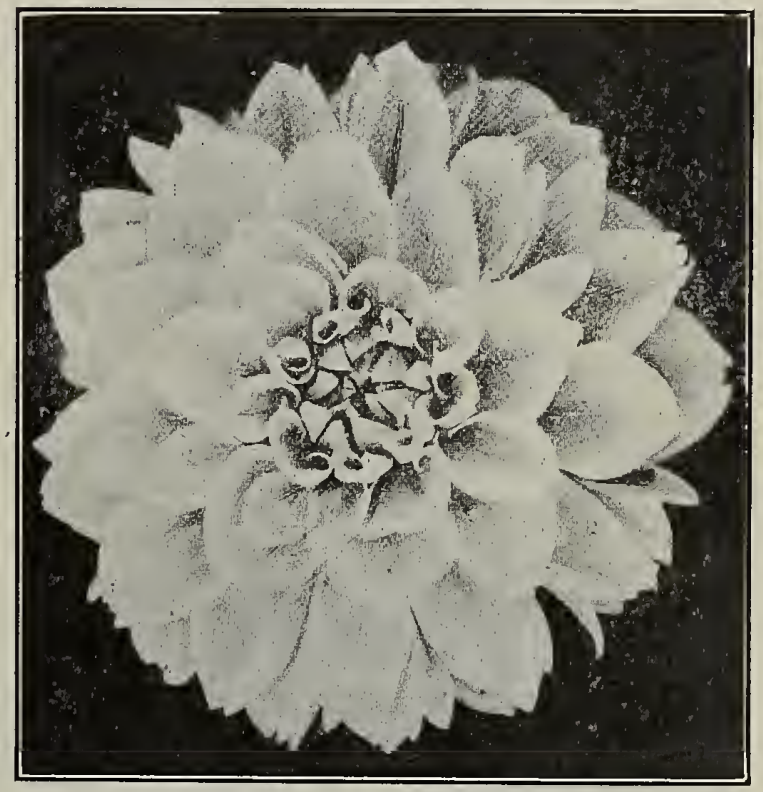

Dahlia-Mrs. Roosevelt Much reduced.

BLACIK DIAMIOND. The color is dark, jet-black when the flower first expands, and gradually changing to a deep velvety maroon-black. The flowers are large, of regular form, and good substance.

FRANK SMITH. Deep maroon, tipped white; large and full to the center; petals beautifully quilled. One of the best "Fancies."

*GERMANIA. A novel variety that has attracted great attention; bright deep pink; petals reflexed and ser rated.

GRAND DUIKE AIEXIs. A magnificent flower of large size and distinctly unique petals are rolled up so that the edges overlap; color pure white.

*JUDAH. The color varies-sometimes solid primrose yellow, sometimes primrose-yellow shaded and suffused old gold, sometimes striped and penciled crimson, sometimes the flowers are solid crimson. these types often appear on the same plant

LOTTIE ECKFORD. This is a "Fancy Dahlia." The ground is white, spotted and striped with pink and crimson.

MAID OF KENT. Another "Fancy Sort." Scarlet-crimson at base of petals, point of each being white. 


\section{DAHLIAS-Continued}

OLYMPIA. One of the grandest Fancy Dahlias to date. The flowers are of immense size, measuring 6 to 7 inches across, with full high center and, owing to the great length of the petals when opening, there is never a green center showing, even when the buds are never a green center showing, even when the buds are
first expanding. The color is deep rose-pink, striped and penciled with rich crimson.

RED HUSSAR. The flowers are large, of regular form, with a full high center and good texture. The color is purest cardinal-red, without trace of purple or crimson. It is the best bright red Dahlia for florists, because its free-branching habit gives long, stiff, but slender stems with practically no disoudding.

STORM KING. Pure white; perfect form. An extremely profuse bloomer. Dwarf habit. Fine for bedding.

\section{SINGLE DAHLIAS}

All these are of dwarf, bushy growth, and need but little staking, unless in very exposed situations. Many people prefer single Dahlias. They are like most single The coloring is equally vivid and brilliant, and they bloom even more abundantly. A few plants will give quantities of cut flowers from early June to the middle of November, if old blooms are kept picked off.

25e each; \$2.50 per dozen.

HRILliANT. Deep, rich, vivid, velvety scarlet; flowers medium-sized, produced on good stems; good keeper; exceedingly free flowering. A mass of bright color throughout the entire season.

BLACKBIRD. Black, changing to rich, velvety maroon with a bright red spot at the base of each petal; the flowers are large, regular iri form and of fine texture and finish.

GRACILIS. White, tinted blush; dashed, splashed, streaked, and spotted with crimson and dark red in a beautiful manner. Of the hundreds of blooms covering a single bush scarcely two are marked alike. Very fine.

GAILlardia. Golden-yellow, with a broad band or disc of red around the yellow center; named from its striking resemblance to Gaillardia grandiflora. distinct type that will become a popular favorite.

*LAWRENCE KRAMER. The color is a deep, bright rosy pink of the richest, brightest shade, without tint or blemish, in marked contrast with so many of the so-called pink singles, which are shaded crimson, violet or lavender.

TWENTIETH CENTURY. A grand new single sort; flowers pink, streaked white; of immense size, perfect form; stems all that can be desired. The best.

* RAINBOW. Intensely bright crimson, shaded cerise and tipped with pink. The blending and shading of these colors is indescribable; it fairly shines with a metallic luster that no words can do justice to. One of the very best.

ST. GEORGE. Pure yellow, without spot or shading; long stems; free bloomer.

\section{COLLARETTE DAHLIAS}

An entirely new type of single Dahlia, which has produced a great sensation the past three years whereever shown, and which has been awarded highest honors. The peculiarity of the type lies in the development of the four stamens into short rays or petals at the base of the petal, which form a frill or collar around the center. As the collar is entirely distinct in color from the rest of the flower, it is most unique and striking. We offer two of the most distinct varieties. We were pleasantly surprised and delighted with the habits of both these varieties, as they are of dwarf, branching habit and extremely profuse bloomers, starting with the earliest and continuing in full bloom until frost. $35 \mathrm{c}$ each. JOSEPH GOUJON. The flowers are quite large, orangered shading to deep red, with light canary-yellow collar. This variety has of the regulation eight.

* PRESIDENT VIGER. The most beautiful and striking of the two varieties. Rich, deep blood-red, shading darker toward the base of the petals, with pure white collar, occasionally suffused with rosy carmine. The collar, occasionays perfect, with eight petals; it is an extremely early and profuse bloomer.

\section{Carnations}

In the following list will be found none but the newest and choicest varieties. Ready March.

NOTE.-Customers selecting their own Carnations are respectfully requested to add to their orders a few supplementary sorts, lest by previous orders the stock of any particular variety should be exhausted; this being especially necessary late in the season.

\section{CHOICE NEWER SORTS}

BOSTON MARIET. We wish to call particular attention to this grand white variety, as we know of no other sort of any color that will produce as many

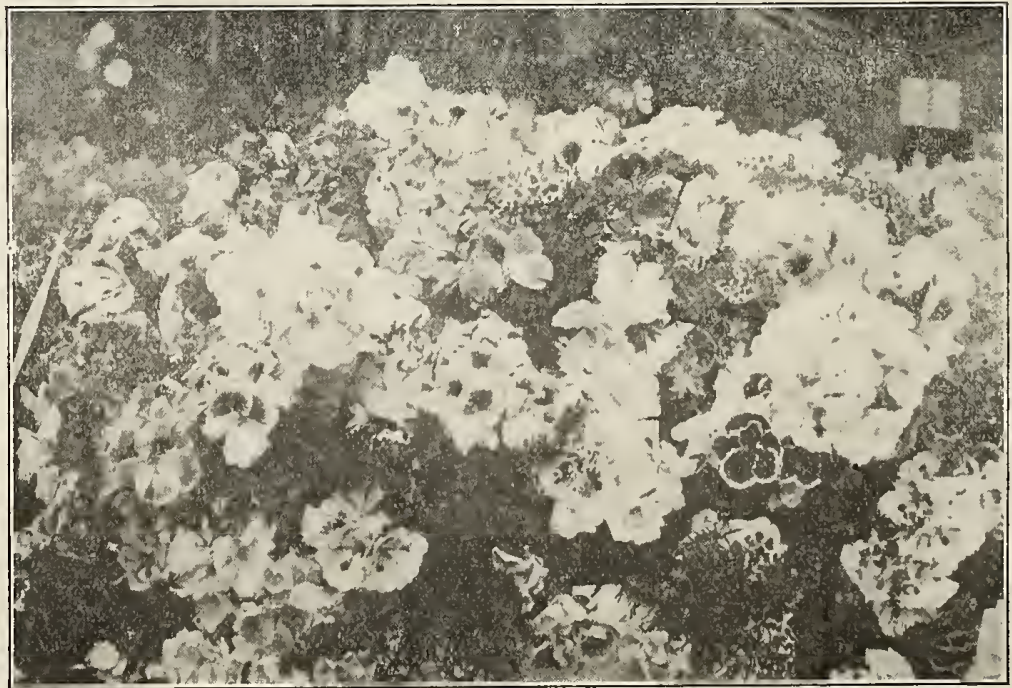

Lady Washington Geraniums (Pelargoniums) Photo C. C. Morse \& Co. flowers or do as well out of doors as this variety. fowers or do as well with long wiry stems, which hold the snowy white blooms perfectly erect.

ENCHANTRESS. Of recent introduction. A very pleasing shade of light pink, deepening toward the center; flowers very light pink, borne on long stiff stems; habit of plant strong and vigorous.

FLA MINGo. A very large, intense scarlet; carried on unusually long and stifi stems. Very free for such a large flower.

HARRY FENN. A very large, extremely full flower, deeply fringed and very fragrant. In color, a fine crimson, a little lighter in color than Governor Roosevelt and much freer in bloom than that variety. Stems long, and stiff enough to carry the flowers very nicely.

THOMAS W. LAwson. A grand deep pink carnation of very large size; blooms carried very erect on strong heavy stems: unusually free in growth and bloom. No carnation growth and bloom. No carnation to date has created such a sensation as this variety, thirty thousand dollars having original stock.

MRS. PATTON, A beautiful variegated carnation; sent out by the origincarnation flowers very large ator oll; caried on long wiry stems: and full; caried on long wiry stems; ground color pure glistening white delicately stripped with fine pink stripes. Very free in growth and bloom. It is with pleasure that we call the attention of all lovers 
NELSON FISHER. A very deep pink in color, deeper than Lawson; flowers finely formed, with fringed edges. We can recommend this variety very highly for out-door planting. To say that this variety originated with the same grower that sent out Mrs. Lawson and Mrs. Patton, should be a guarantee for its sterling qualities.

PRESIDENT ROOSEVELT. Deep, rich brilliant scarlet, heavily shaded maroon; the form in this novelty is as near perfect as in any carnation yet produced. The size averages fully 3 inches in diameter; the stems are very long and stout.

WHITE LAWSON. A grand white variety; a sport from Mrs. Thomas W. Lawson. First introduced in 1904; one of the very finest whites to date. The fact that this variety is a sport from Mrs. Lawson should recommend it to all lovers of carnations.
VARIEGATED LAWSON. Another sport of that grand variety-Mrs. Thomas W. Lawson. Color, pure white ground, striped with delicate pink. A peculiar feature of this variety is that when several blooms are placed together the ground color appears to be a very placed together the grica

PROSPERITY. One of the most remarkable Carnations yet originated, producing probably the largest average size blooms of any variety known, the flowers averaging from $3 \frac{3}{4}$ to 4 inches. The plant is extremely healthy in growth and a continuous bloomer. It is a first-class keeper in every respect and a splendid shipper. The color is distinct from any other variety, the ground color being pure white overlaid with pink mottles, deepening toward the center, the color scheme reminding one of the beautiful tints often seen in azaleas and rhododendrons.

\section{Geraniums}

Price of plants in $31 / 2$-inch pots, $20 \mathrm{c}$ each; $\$ 2.00$ per dozen.

ALICE OF VINCENNES. Border of intense scarlet, forming $a$ band around the body, color a rosy-pink, heavily veined with scarlet, center white; a very brilliant combination of colors. Single.

COUNTESS OF HARCoURT. Pure double snow white. A grand bedder. Florets large and beautifully formed.

GENERAL GRANT. A fine scarlet; good bedder.

JEAN VIAUD. Soft, pure pink, with two white blotches; dwarf, stocky grower, rigid stems, large trusses, perfect florets.

M. P. MORIA v. Large flowers of rosy salmon, center white, surrounded by a halo of bright salmon. Single.

MARQUIS CASTELLANE. Immense flowers about $2 \frac{1}{2}$ inches in diameter; two beautiful shades of red; petals undulating on the edges.

MADAME LANDRY. Double; very free and constantly in bloom throughout the season; trusses large, and florets of the finest size and circular in form; color clear salmon; center shading to copper with a white eye.

MADAME I. ABBEMA. This lovely variety has large, round florets of an exquisite shade of blush pink, round florets of an exquisite shade of blush pink, petals.
S. A. NUTT. The very best of the dark crimson scarlet bedders.

TAMATA VE. Iarge, round, full flower; clear bright red shading to orange.

THE SWAN. A grand double white variety, constantly in bloom.

\section{IVY-LEAVED GERANIUMS}

Are indispensable for covering banks, fences, etc. They are almost continuously in bloom, and require very little water.

CHAS. TURNER. The handsomest Ivy Geranium ever introduced; flowers $2 \frac{1 / 2}{2}$ inches, trusses 6 inches across. The color is a deep bright pink, approaching scarlet in color, the upper petals feathered maroon. Qcarlet in color

CHERRY RED. A very fine double variety.

FLOURENS. Large irregular flowers, salmon shaded with rose, large petals.

P. CROzY. A grand hybrid between the zonales and ivies, having the foliage of the former, while the forms of truss and florets are found only among the ivies. The color is soft bright scarlet, with veinings of maroon. A grand bedder. Profuse in bloom.

\section{Pelargoniums}

(Lady Washington Geraniums) - Regal, Fringed, and Decorative Varieties.

This magnificent group includes those varieties whose habit is more robust, and the flowers much larger than those of the Show Pelargoniums. Their petals are either frilled or fringed, and overlap each other in such a manner that they present the appearance of being double. Several of the varieties display a warmth and richness of coloring not found in any other class.

$25 c$ each; $\$ 2.50$ per dozen.

Please state if we can substitute, if necessary.

A N ITA. A most charming flower of extraordinary size, combining with it great freedom of bloom; of a lovely shade of brightest pink; upper petals grandly feathered with dark, velvety crimson, with an almost white center.

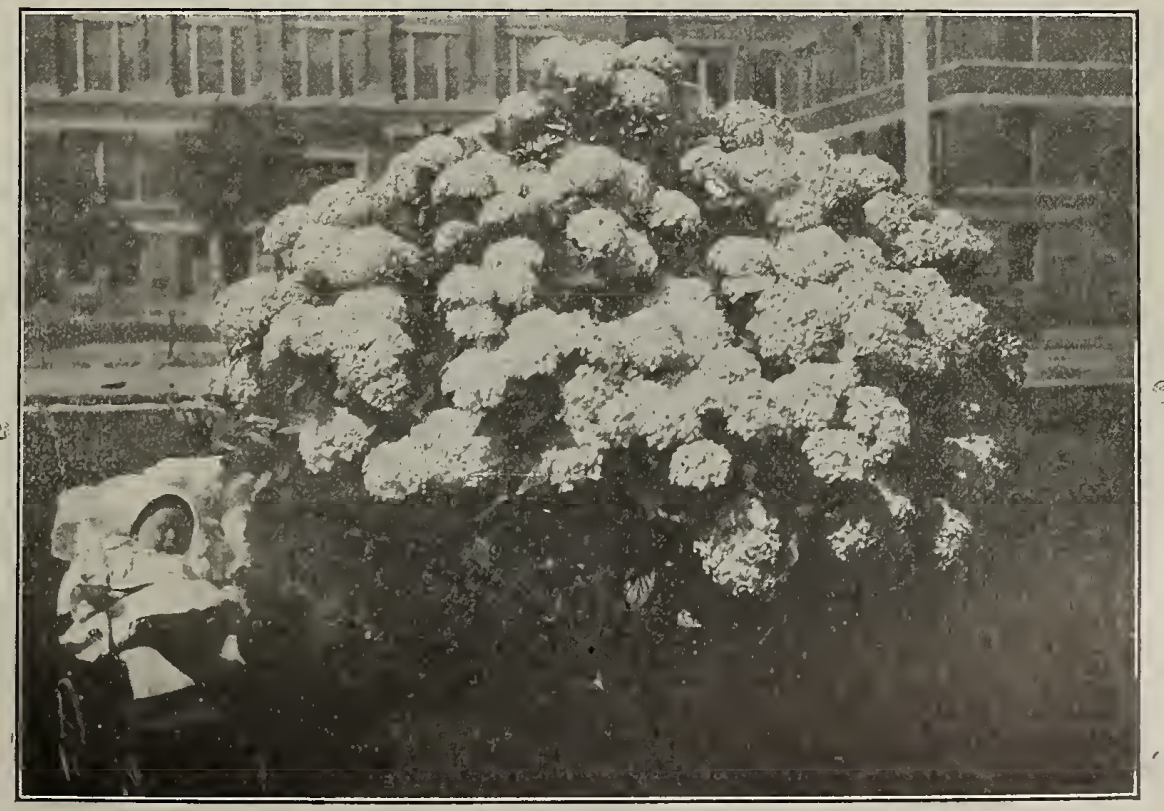




\section{PELARGONIUMS-Continued}

DOROTHY. Soft shade carmine rose; white center surrounded with lilac shade; all the petals margined rounded with lilac shade; all the p

DUKE OF ALBANY. Deep, rich crimson maroon, margined with rosy lake; light center, surrounded with violet, rose shading. A grand, dark variety, having a very full appearance.

DUCHESS OF 'TECK. Very large trusses of extra large semi-double white flowers; petals undulated and frilled.

E. G. HILL. Brilliant dark maroon, shaded scarlet, lower petals lighter shade, with white center; very large. GOLDEN GATE. Large flowers, with elegantly fringed margins, of a beautiful orange-scarlet color; center light maroon; upper petals blotched with intense black.
MABEL. Upper petals brilliant dark maroon, under petals soft rosy pink; large white center.

MADAME THIEBAUD. Blotched and marbled rose and white ground; upper petals marked with crimson maroon; large white center, and edges of petals also white.

MILTON. Upper petals grandly blotched dark maroon, surrounded with bright crimson and edged with rose, lower petals soft pink, feathered with crimson; light center. Light trusses of fine, elegantly fringed fowers.

PRINCE GEORGE. Large trusses of finely fringed white flowers, faintly suffused with blush; all petals spotted with purplish lake; two upper petals more marked than the others.

\section{Chrysanthemums}

Chrysanthemums should not be planted out earlier than March 30th. At that time we can supply plants from 3 -inch pots at $15 \mathrm{c}$ each, $\$ 1.50$ per dozen, of the following choice sorts:

A. J. BALFOUR. A grand Japanese incurved. Color, rose-pink, broad petals of great substance. Fast gaining a first place, for there is nothing to touch it in color; a pink that is dazzling.

COLONEL APPLFTON. Large yellow; late; fine incurved. GOLDEN WEDDING. Nothing finer among yellows; shines like burnished gold; the standard for measuring color.

LILY MOUNTFORD. A beautiful variety with outer rows of petals pure pink; center salmon; very large and

MAJOR BONNAFFON. The most widely grown of yellow sorts for commercial purposes.

MOUNIER. Very large deep yellow; form broad, reflexed petals twisting; extra good late sort.

MRS. BUCKBEE. A fine, pure white; incurving, with outer petals reflexing, strong stems clothed with handsome foliage. Its fine keeping qualities and pure color make it of extra value.
MRS. COOMBS. Bright rose color. In heavy demand on account of the record it has made. The flower is immense, with broad, slightly reflexing petals; dwarf, and with elegant foliage. One of the best of the newcomers, either for commercial or exhibition purposes. very early midseason.

MRS. JERONE JONES. A beautiful glistening white, Japanese incurved, still widely grown and greatly admired.

IIRS. ROBINSON. Probably the most widely grown of whites for its date; very early midseason.

ROBT. HALLIDAY. Is still near the top of the list of early yellows; it has taken several years to show its possibilities, but this variety has attained wide popularity, and deservedly so. It is indispensable; very large when well grown.

THE QUEEN. A grand pure white.

\section{Abutilons}

$15 \mathrm{c}$ and $25 \mathrm{c}$ each.

BOULE DE NEIGE. The best pure white, up to date.

GOLDWN FLEECE, OR GOLDEN BELLS. A bright golden-yellow abutilon, of strong, vigorous habit. SAWITzI. Foliage beautifully edged creamy white.
SCA RIET GEYI A rich bright scarlet

THOMPSONII PLENA. Has perfectly double flowers, that resemble in form a double hollyhock. Color a deep orange, shaded and streaked with crimson; the foliage is beautifully variegated

\section{Heliotrope}

$15 c$ each, \$1.50 pex dozen. Strong plants (ready April), QUELN. Very dark.
SAPPHIRE. Purple, white center.

SNOW WREATH. White

\section{Violets}

CALIFOrnia. Large, single blue. 60c per dozen MARIE LOUISE. The well-known double light purple
variety. Princless of Wales. This grand variety is of French

origin; produces grand single flowers of a beautiful violet blue color in great abundance, and after years of trial has been found to be the best single blue. 60e per dozen

\section{Hardy and Herbaceous Perennials}

For many purposes hardy perennial plants are indispensable. To fill vacant spaces among shrubbery, under trees, etc., they occupy a place in gardening that annuals cannot supply. Once planted they need very little attention, and can be left from year to year only thinning out now and then. By judicious selection they can be had in bloom throughout the whole year.

ANEMIONE JAPONICA (Wind Flower). One of the most desirable of hardy herbaceous plants. As a cut flower we consider the Anemone invaluable. We offer the White and Pink. $25 \mathrm{c}$ ench; $\$ 2.00$ per 10

CLEMA'IIS DAVIDIANA. A herbaceous variety of the Clematis; the flowers are blue and come in large clusters; very fragrant. COREOPSIS LANCEOLATA. This handsome perennial is now probably the most popular perennial plant in cultivation. It is continually one mass of golden yellow. The flowers, which are of graceful form, are invaluable for cutting for decorative purposes.

HELIAN'THS MAXIMILLIANA (Single Sunflowex). A most graceful single-flowered variety, growing from five to seven feet high, continuing in bloom very late in the season. The flowers are produced in long graceful sprays, which make it invaluable for cutting purposes.
GAILI.ARDIA GRANDIFLORA. The brightest of all Gaillardias. Fowers bronze scarlet, bordered with golden yellow, three inches in diameter, produced on
long stems.

IEUCHERA SANGUINEA. A desirable hardy herbaceous plant, growing one and a half feet high. The flowers are produced in loose graceful spikes and come in great profusion. In color it varies from coral-red to crimson, and when in perfection dazzles the eye with its brilliancy. It blooms all summer. 25 e each; $\$ 2.00$ per 10

IRIS. JAPA N ESE. $20 \mathrm{c}$ each; $\$ 2.00$ per dozen PHLOX-PERENNIAL

One of the finest of summer and autumn flowers; of easy culture and they produce in great profusion for a long period, flowers of fine form and substance and of bright and various colors; the flowers come in large 
trusses and are really a most desirable plant for garden decoration. We can supply the following sorts at $25 \mathrm{c}$ each; $\$ 2.00$ per 10 .

ALCESTE. White, shaded lilac, blush, violet center.

ESCLARMO NDE. Rosy lilac, purple center.

ECLAIREUR. Purplish crimson, with white halo.

DUQUESCLIN. Blush violet, shading to white, crimson eve.

JEAN D'ARC. Pure white.
PEARL. White.

PANTHEoN, Pink or salmon-rose; very distinct.

R. P. STRUTHERS. Brilliant rose red, with crimson eye.

wy. RoBINSov. Pale salmon, with rosy center; very fine.

SHASTA DAISY ("The Alaska"). An improvement on Mr. Burbank's original Shasta Daisy. The flowers are very large, borne on long stems and very free in very large, borne on long stems and very free in satisfactory perennial.

\section{Miscellaneous Flowering and Bedding Plants}

Bedding and Border Plants should not be set out much before April 15th, when all danger from frost is over.

AGAPANTHUS UMBELLATUS (Blue African Lily).

Extra strong, established plants, 35c each

ALTERNANTHERA. Much used for bedding purposes of low growth; stands clipping well. Ready about April 15 th. Yellow and Red Varieties, 50e per dozen? $\$ 3.00$ per 100 .

ASTER, SEMPLE'S NEW BRANCHING. Crimson, lavender, pink, and white. Ready about April 15th

35e per dozen; $\$ 2.00$ per 100

BEGONIA VERNON. This variety grows about eighteen inches high. The foliage, in the sun, turns deep olive green, shaded and edged with bronze purple; the flowers are bright red in color; magnificently set off by abundant dark foliage. $15 \mathrm{c}$ each; $\$ 1.50$ per dozen

BEGONIA ERFORDI (Beauty of Erford). It is more dwarf and spreading than Vernon and bears three times as many flowers. The color is a lovely soft pink throughout, which does not fade in the hottest sun. It blooms ten months in the year; grows abou twelve inches high, and makes a most beautiful border for Cannas, Geraniums, Scarlet Sage, etc. All ready about April 15th. 15c each; \$1.50 per dozen

BEGONIA. TUBEROUS-ROOTED. Double varieties, separate colors, 20c each. Single varieties, 15e each.

BOUVAR DIA JASMINOIDES. In this plant are combined rare qualities; the flowers come in clusters; pure waxy white, the fragrance emitting therefrom is of sweet, subtle odor; it blooms for a long period during summer and autumn, and is invaluable for cutting. The plant grows from three to four feet high, and should be in every collection.

$35 \mathrm{c}$ each

CINERARIA. As a winter blooming plant for house culture, or for use for bedding under the shade of large trees, these are invaluable. We offer a fine strain. 25 e encli; $\$ 2.50$ per dozen

CosMos. Crimson, pink, white and yellow. Ready about April 15 th 25e per dozen; $\$ 1.50$ per 100 DAISIES. Double, all colors. 35e per dozen; $\$ 2.50$ per 100 ECHEVERIA (Hen and Chickens). 50c per dozen FUCHSIAS. Best assorted. $15 \mathrm{c}$ each; $\mathbf{\$ 1 . 5 0}$ per dozen GAZANIA SPLENDENS. Flowers orange-yellow, produced in the greatest abundance in the spring and early summer. For making borders, where there is a lack
of water, this plant cannot be beat. GOLDEN FEATHER. Ready A pril.

35e per dozen; $\$ 2.50$ per 100

HYDRANGEA HORTENSIS. This plant is a most satisfactory one, blooming as it does for such a long period; they succeed admirably when planted in a shady place in the garden. As will be seen from the shady place in the garden. As will be

25 each; $\$ 2.00$ per 10. Large plants, 50c each

IMANTOPHYLLUM MINIATUM. Flowers bright brickred produced in clusters on long stems. 50c each LIPPIA REPENS. $\$ 3.00$ per $100 ; \$ 25.00$ per 100 LOBELIA. Dwarf blue. Ready April 15th.

35e per dozen; $\$ 3.00$ per 100

MESEMBRYANTHEMUM. These are much used for bedding purposes and planting on banks and hillsides where there is a scarcity of water. They make a gorgeous sight when massed, as will be seen from the accompanying picture. Perhaps the showiest of them all is the one which produces the large, single, pink, flowers. We can also supply plants of the small, lavender-colored one at 50c per dozen; \$3.50 per 100 MARGUERITE, WHITE. . I5c each; $\$ 1.25$ per dozen HARGUERITE, YELLOW. $15 \mathrm{c}$ each; \$1.25 per dozen PANsies (Morse's Prize Strain). The plants we offer are grown from seed, obtained from a noted grower in Germany, and include almost every shade of color. exquisitely spotted and blotched, veined, mottled, and margined. 50e per dozen. Strong plants (ready March), 75e per dozen.

PETUNIA, SINGLE. Ready April 15th.

15c each; $\$ 1.50$ per dozen MULA, COINESE. Invaluable for winter and early
SALVIA SPLENDENS. Scarlet flowers; continuous bloomers. Ready April. 10c each; $\$ 1.00$ per dozen SEA PINIK (Ammeria). Very dwarf, requiring no trimming. Flowers rose pink. 50c per dozen; $\$ 3.00$ per 100 SPERGULA. Very dwarf; splendid for edging. Square foot, 50c. One square foot would make an edging 25 feet long.

sToCKs. In fine assortment. Ready April.

25e per dozen; $\$ 2.00$ per 100 GRBENA. MISS WILMOT. Color, dark pink; very large truss; stems long, thus making it valuable for cutting; a long and continuous bloomer. An excellent novelty and one which we can recommend. (Ready March.) $15 \mathrm{e}$ each; $\$ 1.50$ per dozen

VERBENA, MAMMOTH. The flowers are very large, of brilliant colors, and have large, distinct eyes. All colors. Ready Ápril.

10e each; \$1.00 per dozen

\section{GLOXINIAS}

These grand bulbous plants are much used for greenThe e frowers are single, trumpet-shaped and come in white, pink, lavender, and spotted, and are of a rich velvety texture. Plant in March, April or May; one bulb in a four-inch pot, afterwards shifting to a five or six-inch pot.

SEPARATE COLORS.

FIN FST MIXED.

25e each; \$2.50 per dozen

\section{JAPANESE PAFONTES}

TREE PAEONIES. The finest of all Paeonies. Like most of the Japanese importations, they are quite hardy and remarkabe for their great perfection of flowers, both in size and richness of color. They grow to the size of a large shrub, increasing in vigor and size of flowers season after season.

Choice imported varieties, $75 \mathrm{c}$ each

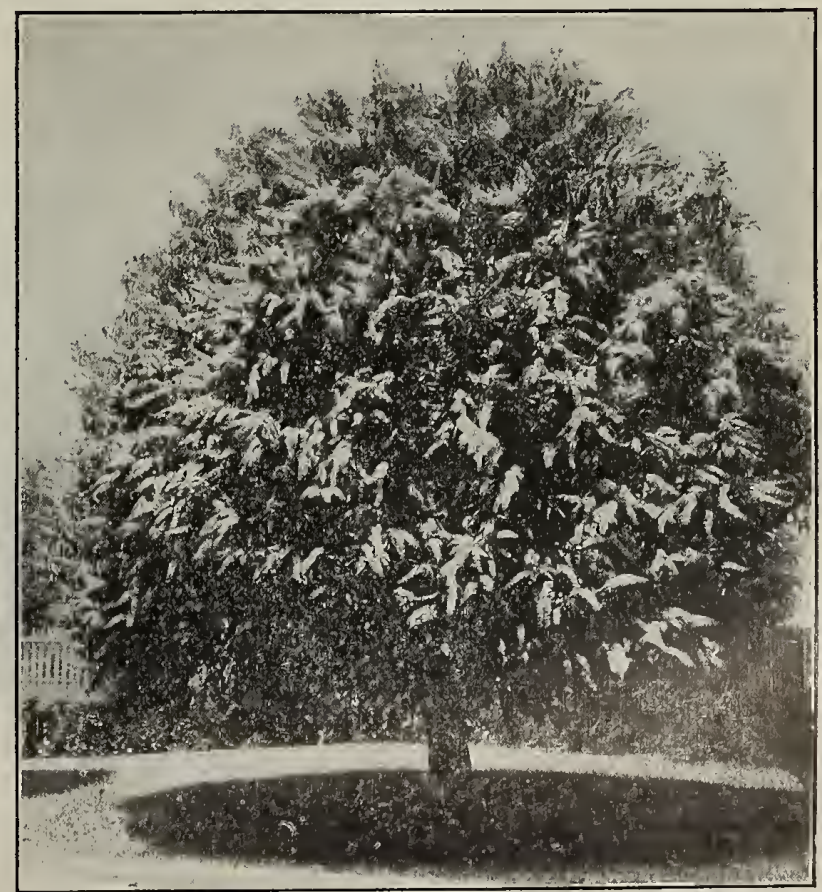

Ligustrum Japonicum (Japanese Privet). In tree form. For description, see page 78 . 


\section{MISCELLANEOUS FLOWERING AND BEDDING PLANTS-Continued}

\section{HERBACEOUS PAEONIES}

HERRACEOUS PAEONIES. Herbaceous Paeonies are among the showiest and most useful plants, and are becoming popular with the public. They are all hardy and admirably adapted to our climate, growing well in almost any situation or soil, although the flowers will be finer and the color brighter if planted in a deep, rich loam, well manured. We offer a splendid assortment, in six distinct varieties.

30 c each: $\$ 2.50$ per 10

\section{Cannas}

These are, without doubt, the most useful and ornamental plants we have. Their blooms are very showy and continue for a long period; the shades are very brilliant and they are peculiarly adapted for grouping or edging lawns and when supplied plentifully with water they are a mass of magnificent flowers. If you wish a bed of yellow colors you can have it, or scarlet or pink, or spotted. The foliage is also very handsome, being "banana-like" in appearance and when once planted they are there for all time. They are a perennial plant, that is they die down in the winter and start away in the spring. We grow the following newest and choice varieties. Price, 20c each; $\$ 2.00$ per dozen.

ATLANTA. Bronzy pink; good; large flower.

ALLEMANNIA. Orange red, petals edged yellow; very large.

AUSTRIA. Canary yellow; very good.

BEAUTY DES MARCHES. Flowers salmon pink; very fine.

BRANDYWINE. Wine-red flowers, dappled with deep crimson, and sometimes edged with yellow.

C. HENDERSON. Deep crimson.

CORONET. A very fine yellow flowering variety.
EASTER BEAUTY. Light salmon; dark foliage.
J. C. VAUGHAN. Vermillion-orange; large size.

J. AYMAND. Scarlet; large; good.

LOUISE. Rich velvety crimson; very good; tall growing. MUSAFOLIA. A tall-growing sort, with banana-like foliage, excellent for planting in the background or center of beds; flowers red.

MARTHA WASHINGTON. Red, shading to magenta. MAD. C. DUBROST. Salmon, flowers beautifully spotted. PANSY STRAIN. Vivid scarlet.

SOUV. DE PRES. CARNOT. An uncommon shade of salmon pink.

\section{Fruit Trees and Small Fruits}

"Every land owner should be a fruit grower. The symbol of civilization has all along been the orchard, and the evolution of better fruits has been a distinctive feature of the highest progress made by man during the last two centuries."-Extract from "The Orchard and Fruit Garden."

In ordering, please state whether substitution will be permitted, as, when no instructions accompany the order, we feel at liberty to substitute similar sorts.

Articles mentioned in our price-list will be furnished at prices named only when the number specified be taken, except that 5 will be furnished at 10 rates and 50 at 100 rates. We will not, however, furnish long lists of one of a kind at OTHER THAN SINGLE RATES. order.

We will charge for packing sufficient to cover actual cost of same; so when ordering add 10 per cent of

PRUNING. All fruit trees must be pruned after setting out, so as to shape them from their infancy, and this kept up each year. All of the long branches should be cut off, and where there are too many side branches thin out to a few of the strongest; when the tree has on ly one growth, cut back to $2 \frac{1}{2}$ or 3 feet from the ground.

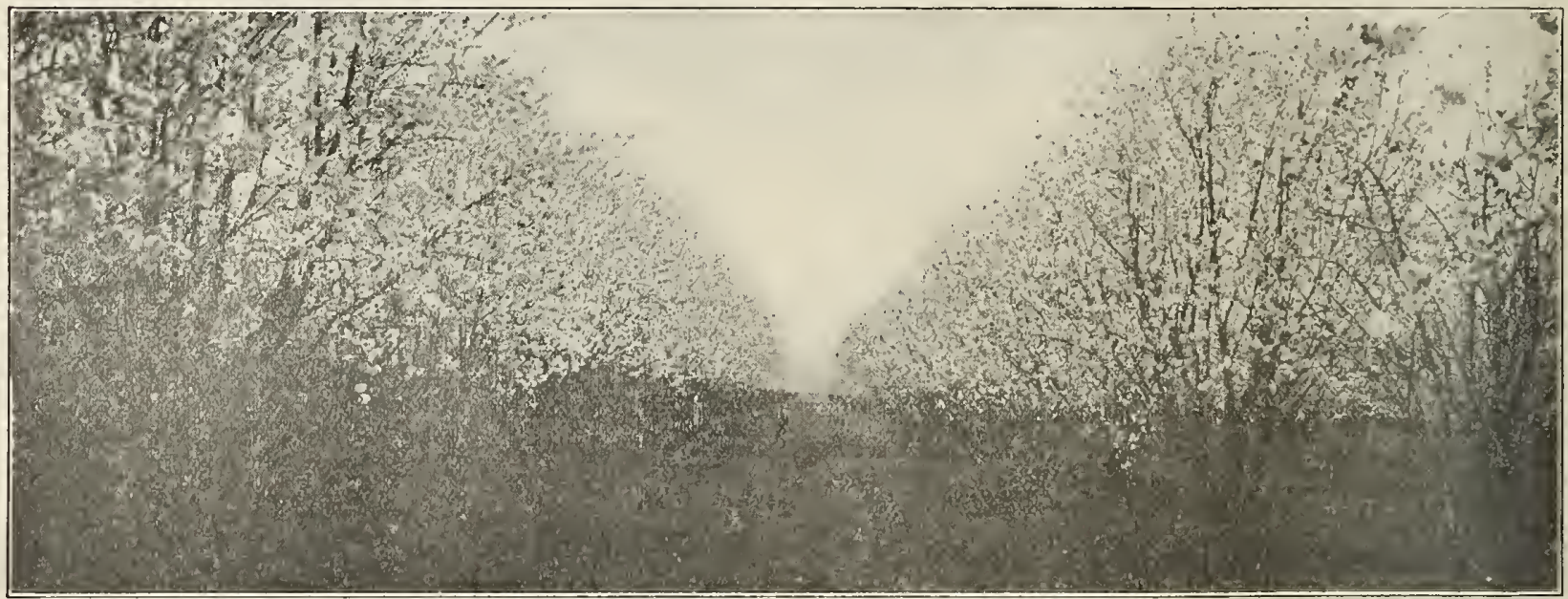

A Califormiam Almond orehard in Hlossoun

Photo C. C. Morse \& Co.

Some attention should also be given to the roots. Sometimes the tree may have a few brolien roots; these should be cut away and when any of the roots are long a little clipping will do them no harm.

PLANTING. Successful planters always dig good large holes for the roots. A little extra labor at this time will be amply repaid in the more rapid growth of the tree, and should the ground be at all heavy or sandy, add some well-decayed manure. Of course, in large plantings this cannot always be done, but we are speaking more particularly to the "home planter." After the tree is set in the hole properly, commence to throw in the soil gently, 
and see that it is well pulverized, and work all in round the roots well. After the hole is half filled up, press down gently with the foot; then fill in the remainder, also going through the same process, leaving the last spadeful or two untrodden. Never, especially in soils that are apt to run together, or adobe, try to plant when the ground is wet. Wait until the ground dries; otherwise your trees will not grow so well.

Planting can be done from December to March, according to the season, but orders should be placed early with us, so as to obtain desired selections.

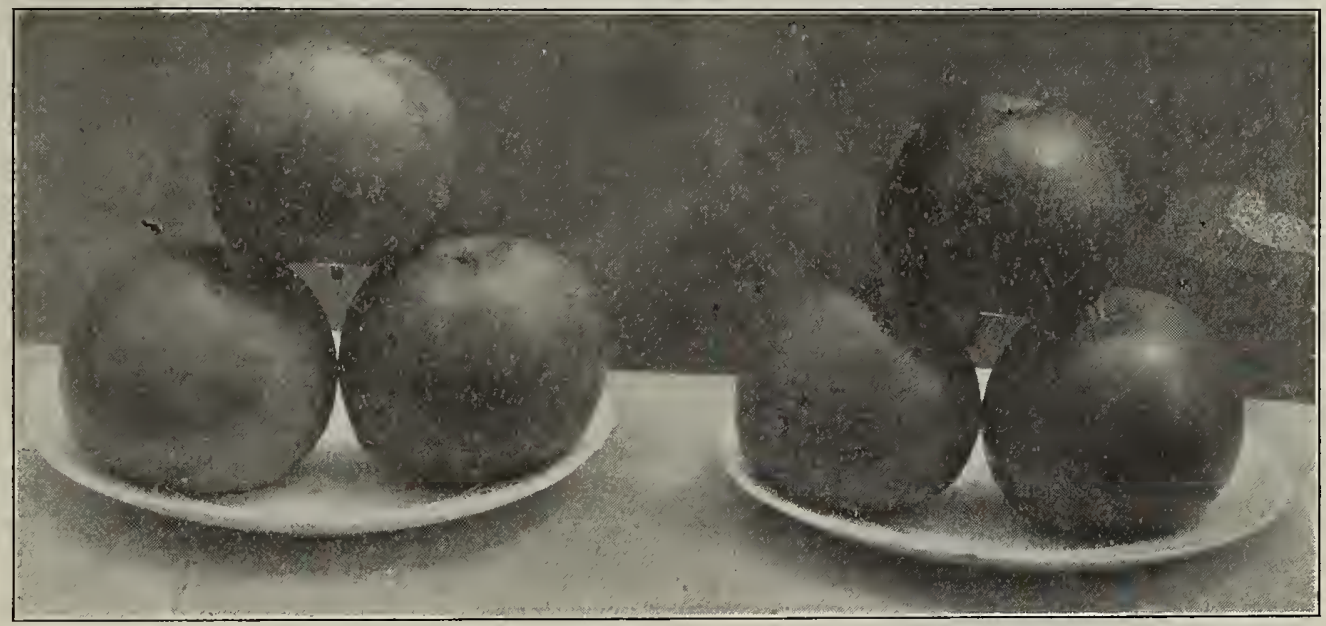

Raldwin Apple

Alexander Apple

Photo C. C. Morse \& Co.

Frequent cultivating is necessary, as there is no better way of keeping the moisture near the surface.

Our list of fruit trees has been cut down to the very best, so that intending planters may depend upon them as being the best. We do not believe in cataloging long lists. Our customers, therefore, will have no experimenting. We do that.

While we aim to have all our fruit trees true to name, and hold ourselves ready, on proper proof, to replace, free of eharge, all stock that may prove untrue to label, or to refund amount originally paid by the customer, it is mutually understood and agreed between the purchaser and ourselves that our guarantee of genuineness shall not make us liable for any sum greater than that originally paid us for such stock as may prove untrue.

We have an unusually fine lot of trees to offer for this coming planting season, and planters will do well to write us for prices on large lots.

\section{APPLES}

The first fruit in importance is the apple. Its period of ripening, unlike that of other fruits, extends nearly or quite through the year. By making judicious selections of Summer, Autumn and Winter sorts, a constant
ALEXANDER. Yellow, streaked with red; brighter red in the sun; flesh yellowish white; crisp, tender and juicy. A very fine market variety. Ripe in September and October.

BISMARClx. Introduced from New Zealand and said to to be one of the most promising of recent introduc-

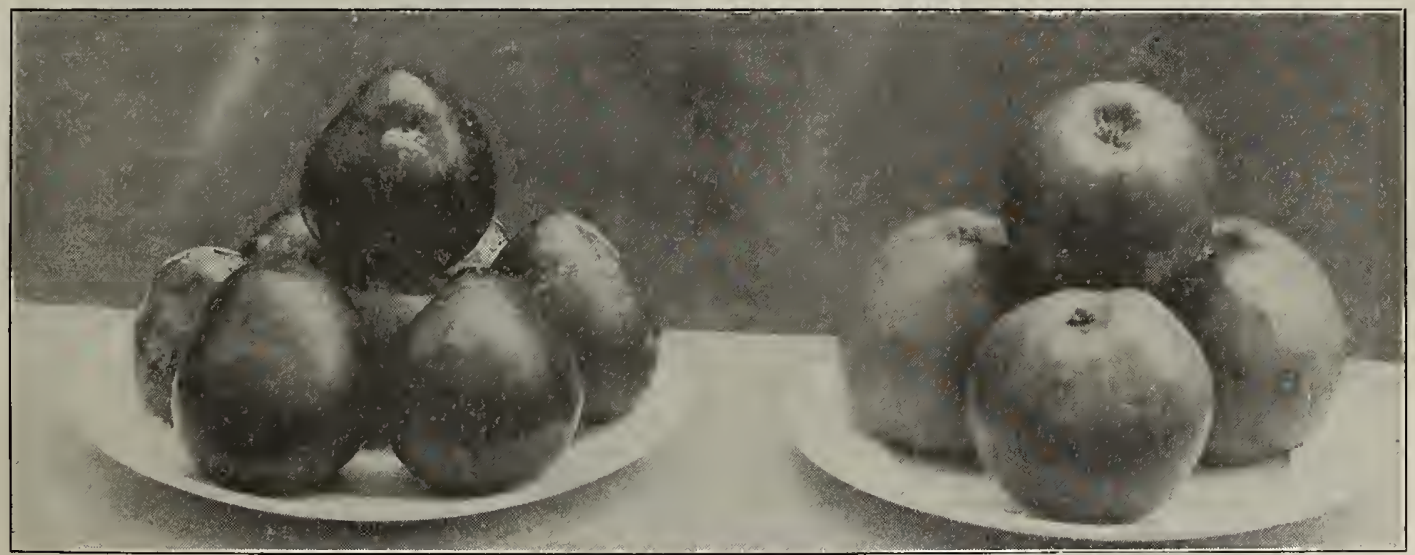

\section{Kelsey Japan Plum}

Gravenstein Apple

Photo C. C. Morse \& Co. succession can easily be obtained of this indispensable fruit.

Price, 4 to 5 feet high, $25 \mathrm{c}$ each; $\$ 2.00$ per $10 ; \$ 18.00$ per 100 . Special price on large lots. tions; a tremendous bearer and one of the very best apples for hot climates. Fruit is of a beautiful golden-yellow color, of the largest size; very highly flavored and as a dessert apple said to have no equal; also suitable for cooking purposes. Ripens early and is a good keeper. 


\section{FIRUT TREES AND SMALL FRUITS-Continued}

BALDWIN. Large, roundish, deep bright red over a yellow ground; flesh yellowish white, crisp, juicy, sub-acid. Ripe in November and December. An exsub-acid. Ripe in No

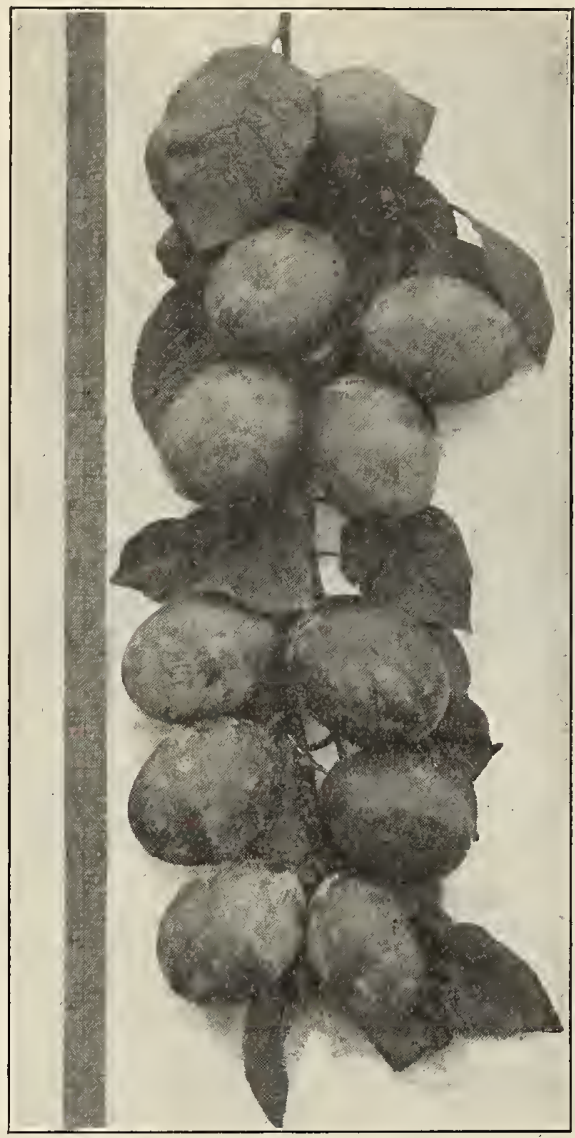

Hungarian Prune

Photo C. C. Morse \& Co.

BEN DAVIS. Large and handsome; striped; of good quality; very productive, Ripe in November and December.

FALL PIPPIN. Very large; yellowish green; flesh white and tender. One of the best fall apples.

GOLDIN PIPPIN. Rich golden yellow; spotted smal gray dots; yellow, crisp and tender; medium size; a late sort

GRAVENSTEIN. A large, striped, beautiful, roundish apple; of excellent quality, juicy, high flavored. good grower and prolific bearer. Ripe in August. A yood market sort.

LAWVER. Bright red, covered with small dots; large; flesh white, firm and crisp; a very showy apple; tree vigorous. Late keeper.

NORTHERN SPY. Greenish-yellow, striped purplish red flesh white and juicy. A fine, late keeper.

RID ASTR ICIMN. Large, roundish, skin deep red; flesh white, juicy and crisp, though rather acid. A hardy, vigorous and early bearer. The best early apple. Ripe in June and July.

RED JUNE. Medium size, oval; deep red, covered with light bloom; flesh white, tender, juicy and sub-acid.

RHODE ISLAND GREENING. Large, greenish yellow A constant heavy bearer. Ripe in October and December.

ROMI BEAUTY. Bright red-streaked yellow; very handsome. A late sort.

WHITE WINTER PEARMAIN. Another sort that bears well in this State. Large, roundish, oblong, and pale yellow, dotted with brown; flesh yellowish, delicate, crisp, juicy, sub-acid; extra fine flavor. A general favorite. Late keeper. A strong and healthy grower. Ripe December to February.
WINESAP. Yellow, ground streaked with red; flesh yellow, with rich flavor; excellent for table. Ripens November to January.

YELLOW BELLFLOWER. Very large, oblong, irregular and tapering toward the eye; skin smooth and of pale lemon color; flesh firm but tender, juicy and subacid. One of the standard apples of California. A good grower and very productive. Ripens November to February.

YELLOW NEW'TOWN PIPPIN. Another variety very successfully grown in California. Large; flesh yellow, firm crisp, juicy, of exceedingly rich flavor. The best winter apple. Ripe January to March.

\section{CRAB APPLES}

Price same as Apples.

RED SIBERIAN. Fruit about an inch in diameter. Yellow with a scarlet cheek. An erect, free grower. Bears very young.

WHITNEY. Glossy green, striped and splashed carmine; flesh firm, juicy and very pleasant flavor.

YELLOW SIBERIAN (Golden Beauty). Large, color beautiful golden yellow.

\section{PFARS}

The Pear does well in all soils, but succeeds best on a heavy loam. Summer and Autumn pears should be gathered at least ten days before they are ripe, and the fruit placed in a dark, cool place, where it will ripen, acquiring a delicious aroma and fine flavor.

Price, 4 to 6 feet, 35c each; $\$ 3.00$ per $10 ; \$ 25.00$ per 100 .

BARTLETT, There is no occasion to describe this variety, so well known is it. A vigorous and strong grower. Bears heavily; good for shipping and canning. Ripe in August.

BEURRE CLAIRGEAU. Very large; red cheek with russet ground. Bears very heavily and when quite young. Flesh rather coarse at the core. Fine shipper to Eastern markets. Ripe in October.

BEURRE HARDY. This autumn pear is very desirable on account of its fine flavor and good bearing qualities.

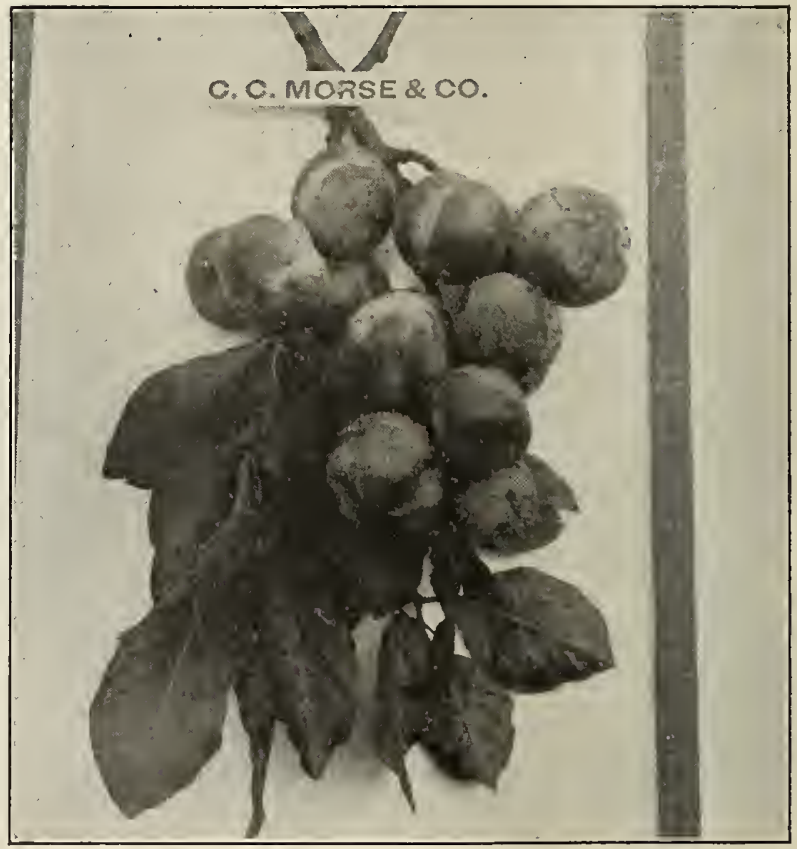

Greengage Plum

Photo C. C. Morse \& Co.

P. BARRY. This pear was raised by the late B. S. Fox of San Jose. The tree is a good grower, bears immensely and when quite young. The color of fruit is deep yellow, nearly covered with rich golden russet: very large. A splendid shipper and late keeper. Best of all late pears. January to March. 
SECKEL. Quite small; rich, yellowish brown; very sweet and productive. Good only for local markets. Ripe in september.
GHEEN GAGE. Small, but of the highest excellence; round greenish yellow, with brown dots; very juicy and sweet. August.

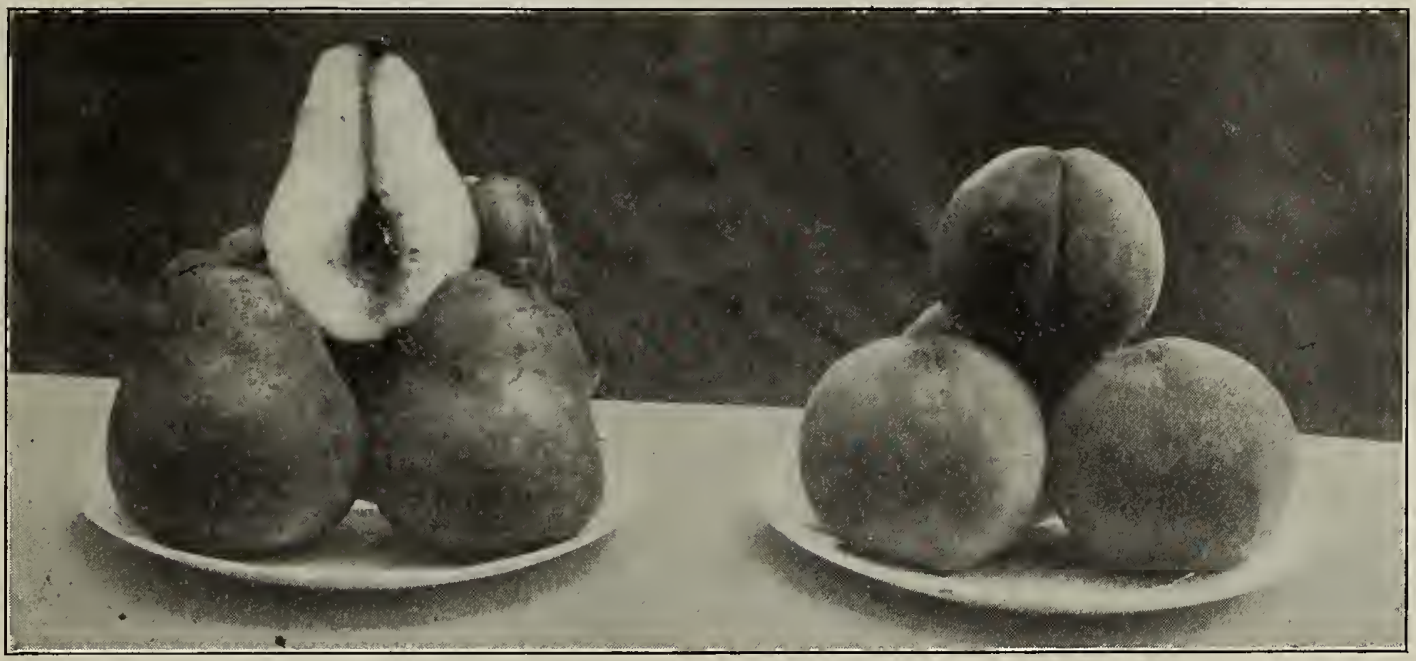

Bartlett Pear

WINTER BARTLETT. Fruit large, closely resembling the famous Bartlett, but ripening four months later.

WINTER NELIS. Medium size, roundish, yellowish green, dotted with russet. Fine flavor. November to January.

\section{CHERRIES}

Cherries thrive in almost any well-drained soil. It is one of the most ornamental of all fruit trees, and very desirable for planting, where beauty and shade as well as fruit are desired.

Price, 4 to 5 feet. $35 \mathrm{c}$ each; $\$ 3.00$ per $10 ; \$ 20.00$ per 100 . BING. Fruit large, dark brown or black; very fine; late. A good shipping variety.

BLACK TARTARIAN. Very large, bright black. The favorite.

ENGLISH MORELLO. Large deep red, juicy and acid. A sour sort.

GOVERNOR WOOD. Very large; rich yellow, with a red cheek; juicy and sweet. Early.

LAMBERT. Very large; bright rich red color; an excellent sort. Ripens two weeks later than the Royal Ann.

LEWELLING (Black Republiean). Large size; a cross between Black Tartarian and Napoleon Bigarreau, having the size and color of the former and the solid flesh of the latter. Late and good.

MAY DUKE. One of the sour sorts, excellent for tarts; rich, dark red, when fully ripe; quite early.

NAPOLEON BIGARREAU (Royal Ann). Very large; amber in color. The favorite white cherry.

\section{PLUIMS}

The Plum tree attains its greatest perfection on our heavy soils, being entirely free from disease. Plums are very hardy and grow vigorously in all sections.

Price, 4 to 6 feet, $35 \mathrm{c}$ each; $\$ 2.50$ per $10 ; \$ 20.00$ per 100 .

BARTLETT. One of the best of Burbank's recent introductions. Said to be wonderfully productive; a very ornamental tree with glossy green leaves, resembling closely the famous Bartlett Pear in habit of growth. flavor and fragrance. Fruit oval, yellow, turning to deep crimson when fully ripe; flesh light salmon colored, firm and juicy. Ripens before Burbank.

colored, firm and juicy. Ripens before Burbank.
BRADSHAw. Very large, dark violet red; juicy and good. Adhering partially to stone. Fine early plum.

BURBA NK (Japanese). Large, yellowish ground, with red cheeks; flesh yellow; firm.

CrimAX. (A New Early Plum.) Cross of Simoni and Botan. Very large, measuring $63 / 4$ by $1 \frac{1 / 2}{2}$ inches in circumference; heart-shaped. A superbly rich plum; extremely early. Ripens in the coast counties early in July, before any other good plum.

DAMSON. Dark blue, with heavy bloom: much used for jams and preserves.
Early Crawford Peach

Photo C. C. Morse \& Co.

IEELSEY (Japan). Very large, heart-shaped, greenish yellow, red cheek on sunny side; flesh very solid and firm, juicy, and with a rich vinous flavor; small pit. September.

WASHINGTON. A magnificent large plum, roundish; deep yellow, with pale crimson blush; flesh yellow, firm, very sweet and luscious, separating from the stone. JuIy and August.

WICKSON. Deep cherry red; flesh amber, very juicy; pit small; flavor delicious. Introduced by Mr. Burbank.

YELLOW EGG. Very large and beautiful; egg-shaped; flesh yellow, rather acid until fully ripe, when it sweetens. Clingstone.

\section{PRUNES}

By the term "Prune" is signified a plum that dries successfully, without the removal of the pit, and produces a sweet dried fruit.

Price, 4 to 6 feet, 35c each; $\$ 3.00$ per $10 ; \$ 25.00$ per 100 . Special prices on large orders.

FRENCH (Petite d'Agen). This is the prune now grown so extensively and successfully in California for drying purposes; medium-sized; egg-shaped, violet purple; very rich and sugary. The best prune; prolific bearer. Can supply this variety on Myrobolan Plum and Almond root. $\$ 200.00$ per 1,000

GERMAN. Long, oval, and swollen on one side; skin purple, with a thick blue bloom; flesh firm, green, sweet, with a peculiarly pleasant flavor. Separates readily from the stone. September.

HUNGARIAN. Fruit very large, with tendency to come double; reddish violet, covered with a handsome bloom. Very juicy and sweet. Good shipper.

IMPERIAL EPINEUSE. Large and uniform in size. Very sweet, and of high flavor; the skin is thin and of a reddish purple when green; when dried coal black.

SUGAR. An extremely early prune. Very large. Ripens August 1st. Skin very tender, at first of a light purple, tinted with green, changing at maturity to dark purple, covered with a thick white bloom. Valuable in localities where the French prune ripens too late for sun-drying.

SILVER. Very large, oval; skin yellow. Makes a very attractive dried fruit, besides being a good shipper and canner. Bears heavily.

TRAGEDY. This is the earliest of all prunes, and earlier than any plum. Good size, dark purple skin, yellowish-green flesh. Sweet and very rich.

\section{PEACHES}

The Peach tree requires a well drained, moderately rich soil, warm sandy loam is probably the best. In order to preserve the continued healthy growth of the tree and the fine quality of the fruit, the peach should 


\section{FRUIT TREES AND SMARL FRUITS-Continued}

have the shoots and branches cut back to one-half the preceding season's growth every year, so as to preserve a round, vigorous head; this should be done the last of February, or as early in the spring as practicable.

Price, 1 year, 4 to 5 feet on peach root, 35c each; $\$ 3.00$ per $10 ; \$ 25.00$ per 100 .

EABERTA. Very large; bright yellow with a beautiful red mottled cheek; juicy and sweet; rcgular bearer. Ripens about end of July.

EARU, CRAWHORD. This is probably the most extensivcly grown of all peaches. Very large; color ycllow, red chcek; flesh yellow, rich excellent. Very productive. Ripens about middle of July.

FoSTER. Large yellow; resembles Early Crawford, ripening a little earlier; an excellent sort.

HACE'S EARLY. Medium size, nearly round; skin greenish white, red cheek; very rich and juicy. Ripens early in July.

IATE CRAWHORD. Very large; yellow with dark red check; flcsh deep yellow, juicy and melting; of exquisite flavor; valuable for canning and drying. Ripens middle to end of August.

IOVELL. Very similar to the "Muir."

IARY'S CHOICE. Ripens about three weeks after the Early Crawford; large to very large; freestone; a fine eating peach; tree good grower and regular bearer. Ripens August.

NuIli. The best of all peaches for drying, because it loses less than any other in the process. Has a delicious, rich, buttery, sweet flavor. The fruit is large to very'large; skin pure yellow; flesh yellow. Excellent for canning. Ripcns end of August.

PHILIP's Cling. Fine, large, yellow; flesh firm, clear, yellow to the pit, which is very small. Preferred by canncrs to any other variety of cling. Its firmness, fine texture of flesh and lateness, not ripening until September, when other clings are practically harvested, makes a demand for this variety far beyond the supply. Ripens September.

SALWAY. A large, yellow English peach, with deep yellow flesh; very juicy, melting and rich. The most valuable late market variety.

TUSCAN CLING. A very large, fine, yellow clingstone; good for shipping or canning. Ripens early.

TIIUMPI. Ripens early; blooms late. The tree makes a very strong growth, bear's young, and yields abundantly. The fruit is of large size, with very small pit; skin yellow, ncarly covered with red, dark crimson in the sun; flesh bright yellow; frce when fully ripe, and of excellent flavor.

\section{APRICOTS}

Beautiful and delicious fruit. In quality and appearance is between the plum and the peach, combining quality of both. Ripening early, together with its delightful flavor, makes it one of the most valuable fruits. Tree is as hardy as the peach; requires about the same cultivation as the peach or plum. For drying and canning it has no superior.

Price, 4 to 6 feet, 35c each; $\$ 3.00$ per $10 ; \$ 20.00$ per 100 . BHENHEr. Very large, handsome, and of a delicious flavor; skin decp orange, mottled with dark brown; highly flavorcd. The best.

HEMSIIRIE. A large and very fine apricot.

MOOHPAPIK. Largest size; rich yellow. Irregular bearer. IROYA. A fine carly variety. Regular bearer.

TIITON. A new sort. A rcgular and abundant cropper; of fair size, light in color. Ripens very uniformly and is very firm; good for drying and canning.

\section{NECTARINES}

The habit and growth of the Nectarine resembles the peach. The fruit has the distinction of a smooth skin, and is of most delightful flavor.

Price, 3 to 5 feet, 35c each; $\$ 3.00$ per 10.

mos'TON. Large, decp yellow, with a bright blush and deep mottlings of red; flesh yellow, without any red at the stone. Sweet though not rich, with a pleasant and peculiar flavor.
HARDWICK. Large, pale green, with a violet red cheek; juicy, melting and rich.

LORD NAPIER. Large, cream color, dark red cheek; flesh white; freestone.

NEW WHITE. Large; skin white; flesh white, tender and very juicy, of rich vinous flavor, pit small and free. Easy to grow wherever nectarines thrive.

\section{ALIMIONDS}

The Almond prefers a loose, light, warm soil. It makes quite a large tree, and should have plenty of room. Trees should be headed low and pruned during the first three years.

Price, 4 to 6 feet, $35 \mathrm{c}$ each; $\$ 3.00$ per $10 ; \$ 20.00$ per 100 .

I. $X$. L. Large kernels; soft shell. Trce is a strong, upright grower.

JORDAN. This new sort is the famous Spanish variety so long sought after by nut growers. First introduced by the late Mr. Rock, of Niles, and later by the United States Department of Agriculture. The nuts are long and are hard-shell; the kernels are single, narrow, long and plump; the kernel is always renarrow, long and plump, the ker exported. In this moved from the nut proper when exported. In this form they bring from eight to ten cents more per thrifty grower and heavy bearer.

NONPAREIL. Large, full kernel; thin shell. Tree of a weeping habit, and a strong grower.

NE PLUS UlTRA. Similar, to above, but of different habit of growth.

PAPER SHELL. Very thin shell; flavor of nut excellent.

\section{QUINCES}

Price, 4 to 5 feet, 35c each; $\$ 3.00$ per 10.

APPLE, or ORANGE. Large, bright yellow. The best. Ripe August and September.

CHAMPION, Very large; flesh cooks as tenderly as an apple, not having hard spots or cores; flavor delicate, imparting an exquisite quince taste and odor to any fruit with which it is cooked. Highly productive, fruit with which it is cook

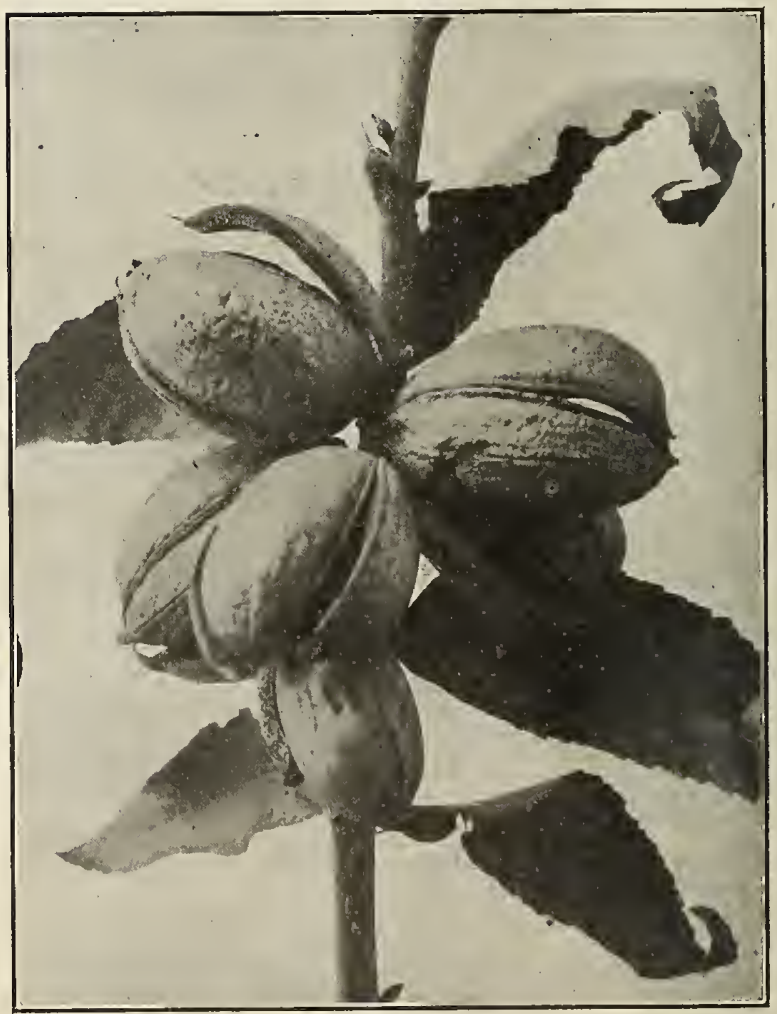

Pecan Nut 


\section{WALNUTS}

AMERICAN BLACK. One of the largest and handsomest of American forest trees; grows freely on this coast, stands transplanting well, bears early, and ought to be extensively ought to be extensively cultivated, not alone
for the nuts, but also for the valuable wood it produces. 3 to 4 feet, 30c each; $\$ 2.50$ per 10 .

SANTA BARBARA SOF'T SHELL. Tree a vigorous grower, early and abundant bearer. The nut is large; kernel white, sweet and readily extracted; shell thin, easily broken. One of the favorites in Southern California. 4
to 6 feet, 50e each; $\$ 4.00$ per 10.

CHABERTE. Nut is roundish oval and of fair size; extra fine flavor: a good bearer. Blooms late On own roots, 4 to 6 feet, 75 c each; $\$ 6.00$ per 10 FRANQUETHE. Nut is quite large, of an elongated oval shape and very attractive; kernel full sweet and of a rich, nutty flavor; a late bloomer.

On own roots, 4 to 6 feet, $75 \mathrm{c}$ each; $\$ 6.00$ per 10

SANTA BARBARA SOF', SHELL. Grafted on California Black root. 4 to 6 feet, $\$ 1.25$ each; $\$ 10.00$ per 10

\section{THE PECAN}

A rapid-growing tree, attaining a height of 170 feet in its natural habitat. In form and contour conspicuous and attractive, producing valuable timber, and a great abundance of smooth, oblong nuts with sweet and delicious kernels. We offer the following named grafted sorts: 3 to 4 feet, $\$ 1.50$ each.

BRADLEY. Large, oblong, ovoid; shell thin, partition very thin; kernel plump, rich and sweet. A prolific and early bearer.

CENTENNIAI. Nuts large, oblong and quite pointed at each end; the shell medium thickness; kernel plump, quality best.

COLUMBIA. Said to be the largest of all the varieties; oblong; kernel solid and rich, very sweet and highly flavored

VAN DEMON, A large nut, averaging 45 to 50 to the pound; oblong in form; shell quite thin; kernel not as large as some varieties; qualities good.

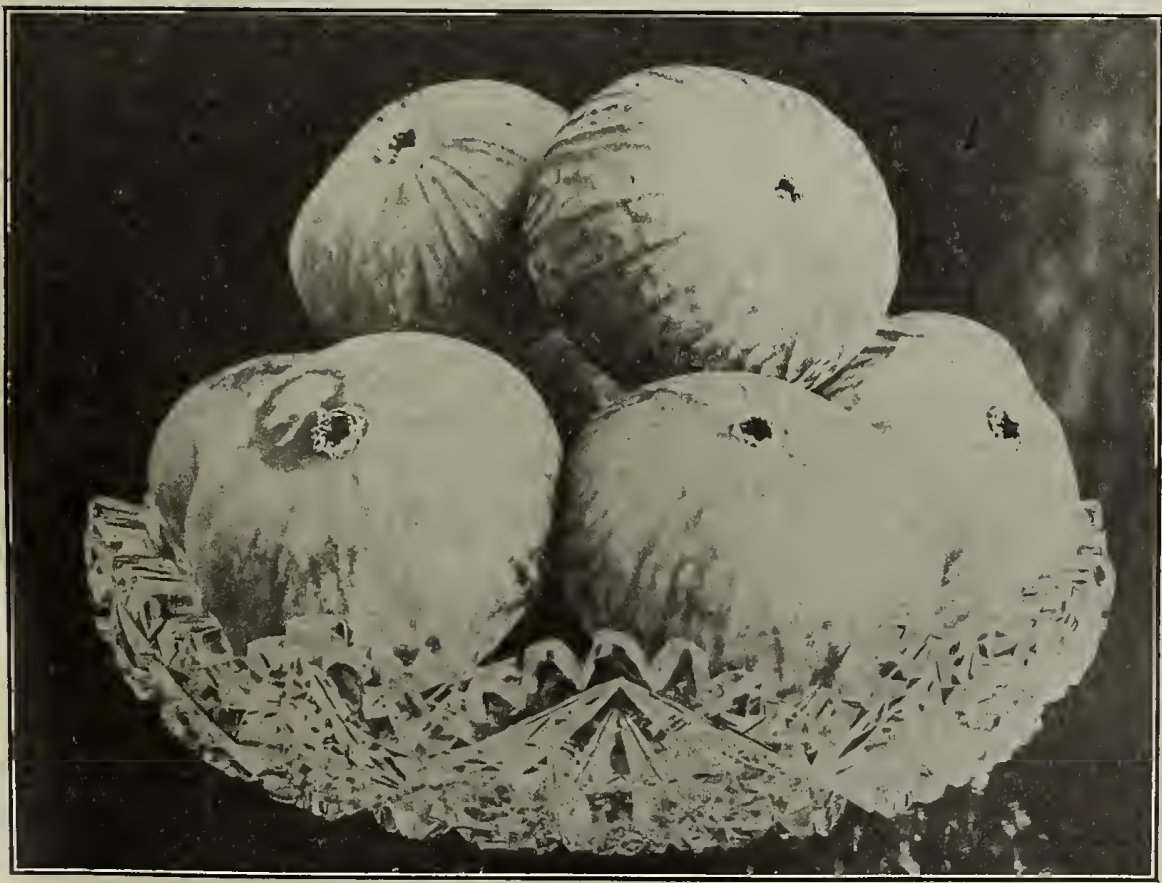

\section{FIGS}

CALIFORNIA HUACK. A well-known local variety. Large, dark purple, almost black when good dried fig. Tree grows to a very large size, and gives immense yield. 3 to 5 feet, 400 earch: $\$ 3 . .50$ per 10.

CALIUYRNA. The genuine Smyrna Fig packed "Ender the name of "Erbeyli" (signifying and known in Turkish as "Lop," and in Grcek as "Lopia." Large to very large; turbinate, pyriform; very short, stalk short; ribs disstalk short; ribs dispale ochre color and widely open when the $\mathrm{fig}$ is mature and before shriveling; skin lemon yellow; pulp reddish Photo C. C. Morse \& Co. amber, sometimes pale amber, turning to dark amber just before falling: seeds large, yellow, fertile overspread with a clear, white syrup, giving the fruit a richness and meatiness surpassed by no other fig: Tree of spreading habit; leaves medium to large, and five-lobed. The dried figs contain 63-92 per cent sugar, which is $1 \frac{1}{2}$ per cent more sugar than found in the imported Smyrna fig. Dries readily and with less trouble and expense than any other fig, dropping. to the ground of its own accord, being practically dry when it falls, requiring when placed on trays only from two to three days' exposure to the sun. by Mr. G. IRoeding, of Wresieo

3 to 5 feet, anc each; $\$ 4.00$ per 10

WHITE ADRIATIC. Fruit large; skin greenish-yellow color; pulp carnation red. Ripens from August to

WILD, or CAPRI. Must be grown in connection with every Calimyrna Fig orchard. 3 to 5 feet, 60 each

\section{OLIVE TREES}

Price, 4 to 6 feet, $60 \mathrm{c}$ each; $\$ 5.00$ per 10 .

MANZANILI, Among the olives of Southern Spain, especially around Seville, the Manzanillo is highly prized both for pickling and oil. The fruit is very large. One of the best olives. Very hardy, prolific and a reoular bearer. Makes a fine pickle, and produces oil of a high grade.

I I S S I O N. The variety found at the old Missions, introduced by the Spanish Padres, an until recently the only sort cultivated in California. It still ranks as one of the most vigorous, productive, hardy and long-lived varieties. It is the most extensively cultivated sort in California, and can be found in almost every county of the State. It is thrifty and vigorous, and yields a fine oil. Can be user for pickling. Ripens late.

NEVADILLO BI, A N CO Medium size, well set on, and its numerou. branchlets usually bend with the weight of the fruit. It is for oil only, of which it yields an abundant supply of
finest grade. Ripens early.

RUBRA. The tree is a very vigorous, upright grower; succeeds in dry, hilly soils. Fruit of medium size, bear's crops. November. 


\section{FRUIT TREES AND SUALL FRUITS-Continued}

SEVILLANO. The tree is a strong grower; leaves green greenish-white on the under side. The largest $c$ olives, and the variety exported from Spain under the name of "Queen Olive." "When ripe, of a bluish-black color; flesh adheres to the pit. A regular bearer. A great olive for pickling; ripens early; its large size, fine flavor, and the fact that it pickles easily, is sure to cause it to be in demand.

\section{CHESTNUTS}

A MERICA N SWEET. A valuable native tree, both useful and ornainental; timber is very durable, and possesses a fine grain for oil finish. Nuts sweet, of delicate flavor, and are a valuable article of commerce. No farm should be without its grove of nut-bearing trees, and the chestnut should be foremost wherever the soil is adapted to its growth. Price, 5 to 4 feet, 50c each

JAPANESE MAMMO'TH. Is remarkable for its great size and fine flavor-in these respects being superior to the European varieties. The tree is similar in habit and growth to the Italian Chestnut; it is a handsome sturdy, healthy tree; it grows in Northern Japan, and has proved to be sufficiently hardy almost anywhere in the United States. Bears fruit at three or four years of age. 3 to 4 feet, 35e each; $\$ 3.00$ per 10

\section{BUTTERNUTS}

A native of the Eastern States, of vigorous growth, spreading head, grayish colored bark, and foliage resembling that of the Ailanthus; produces a large, long6 feet, 50e each; $\$ 4.00$ per 10.

\section{ORANGES}

Price, lifted with balls of soil, 4 to 5 feet, $\$ 2.00$ each; $\$ 1.75$ per 10 .

MALTESE BLOOD. Fruit below medium, nearly round; skin very thin and smooth; pulp ruby-red.

MEDITERRANEAN SWEET. Fruit medium to large pulp solid, with few seeds; ripens late. A very popular sort.

RIVERSIDE WASHINGTON NAVEL. Fruit first-class in every respect; size medium to large, oval, smooth, symmetrical, seedless; pulp fine grained, flavor excellent. A solid, perfect fruit.

VALENCIA LATE OR HAR'S TARDIFF. An orange of remarkably strong-growing habit, and claimed by those fruiting it to be a good bearer; a little later than Mediterranean Sweet, which it resembles very
much.

\section{LEIMONS}

Price, lifted with balls of soil, 4 to 5 feet, $\$ 2.00$ each; $\$ 1.75$ per 10.

EUIEKA. Tree nearly thornless, of rapid growth, and prolific bearer; fruit of the best quality. A general favorite.

LISBOA. Medium size; sweet rind; very strong in acid; very few seeds; tree a rapid grower and very productive.

VILIA FRANCA. Fruit uniformly medium size, fine grained, sweet rind; very few seeds; good keeper; tree strong grower; prolific bearer.

\section{POIMELOS}

This fruit is becoming one of the most popular of the citrus fruits in the Eastern States, and the demand for it thus far has exceeded the supply. The name of "Grape Fruit," by which it is often called, due to its growing in clusters on the tree, is a misnomer. The growing popularity of this fruit is probably due to its medicinal quali. ties, particularly for correcting stomach troubles. The tree is fully as hardy as the orange and is a vigorous grower.

Price, lifted with balls of soil, 4 to 5 feet, $\$ 2.00$ each.

IARSH'S SEEDLESS. Medium, practically seedless; skin thin and smooth; pulp juicy: of superior flavor. Keeps late. A valuable acquisition; its delicious flavor and having no seeds should cause it to take the precedence over many other varieties.

TRIUMPH. Medium size; skin smooth, clear, thin, and fine grained, juicy and well flavored. No bitter in the juice flesh or membranes surrounding the cells and dividing the segments, and very little in the white, inner lining of the peel. Tree bears young. One of the best of the imported varieties.

\section{LIME-MIEXICAN}

BaIked, 3 feet, $\$ 1.50$ each.

\section{JAPANESE PERSIMIMONS}

A magnificent fruit from Japan. Tree highly ornamental. Fruit beautiful in appearance and excellent in quality. 35e each; $\$ 3.00$ per 10 .

\section{MULBERRY}

DownING. Tree of rapid growth; very good as a shade tree, as the leaves are very large; deep green in color; fruit similar in shape to a blackberry; very sweet and aromatic. 5 to 6 feet, $60 \mathrm{e}$ eaeh

PERSIAN, OR ENGLISH. A variety of slow growth, but producing the largest and finest fruit of all Mulberries; very productive; the fruit is large, black, 1 to $11 /$ inches long; very juicy, aromatic, with a subacid flavor; ripens from June to October; good for preserves.

3 to 4 feet, 75 e ench

\section{LOQUAT GIANT}

The fruit of this Japanese tree is very nice. In this State it ripens in April and May, and is about the size of small plums, and comes in clusters; very sweet and refreshing. The plant itself is very ornamental, having large, crimpled foliage of an olive-green color: of large, crimpled foliage of an olive-green color, ench
spreading, dense growth.

\section{STRAWBERRY GUAVA}

The Guava is an ornamental evergreen shrub with pink, shining foliage, and bears when only 2 feet in height. The fruit is smaller than an English walnut, of a fine claret color, and with a favor resembling that of a strawberry. Makes an excellent jelly. 2 feet, 35e each

\section{Grapes FOREIGN VARIETIES}

\section{FOR TABLE AND RAISINS.}

Price, 20c each; $\$ 1.50$ per $10 ; \$ 5.00$ per 100 .

BLACK HAMBURG. Bunches and berries large; black, very sugary and rich.

CALIFOINIA, BLACK. The well-known Mission Grape. CORNICION, HLACK. Berries very, large, oblong; covered with beautiful bloom; skin rather thick and dark. A good shipping sort.

FLAdE TOKAy. A magnificent, large, red grape.

MUSCAT OF A LEXANDRIA. Bunches and berries large, pale amber. One of the best for raisins.

$\$ 18.00$ per 1,000

ROSE OF PEIU. Very large bunches; berries rounding, brownish black. One of the best for table.

SULTANA. Bunches long and very compact; berries small amber colored seedless: make fine seedless raisins; vine an immense bearer. Grows on sandy soils, producing large crops.

$\$ 18.00$ ver 1,000

SWEETWATER. Bunches good size; berries medium size, round fruit.
THOMPSON'S SEEDLESS. Vine an enormous bearer and very rapid grower; bunches very large; berries greenish-yellow, firm, oval, seedless; skin thin, much larger than the Sultana. The raisins are of a very superior quality, and are in good demand. A valuable shipping grape, ripening in July. \$18.00 per 1,000

\section{FOREIGN WINE GRAPES}

BEST ASSOR'TED. \$5.00 per $100 ; \$ 18.00$ per 1,000

\section{RESISTANT GRAPES}

I.ENOIR, RIPARIA, RUPESTRIS ST. GEORGE.

$\$ 4.00$ wer $100 ; 820.00$ per 1,000

Write for prices and varieties of Grapes Grafted on Phyloxera Resistant Roots.

\section{AIMERICAN GRAPES}

Price, 2 years old, $20 \mathrm{c}$ each; $\$ 1.50$ per 10 .

This class of grapes is useful in localities where the more tender foreign varieties will not succeed on ac- 


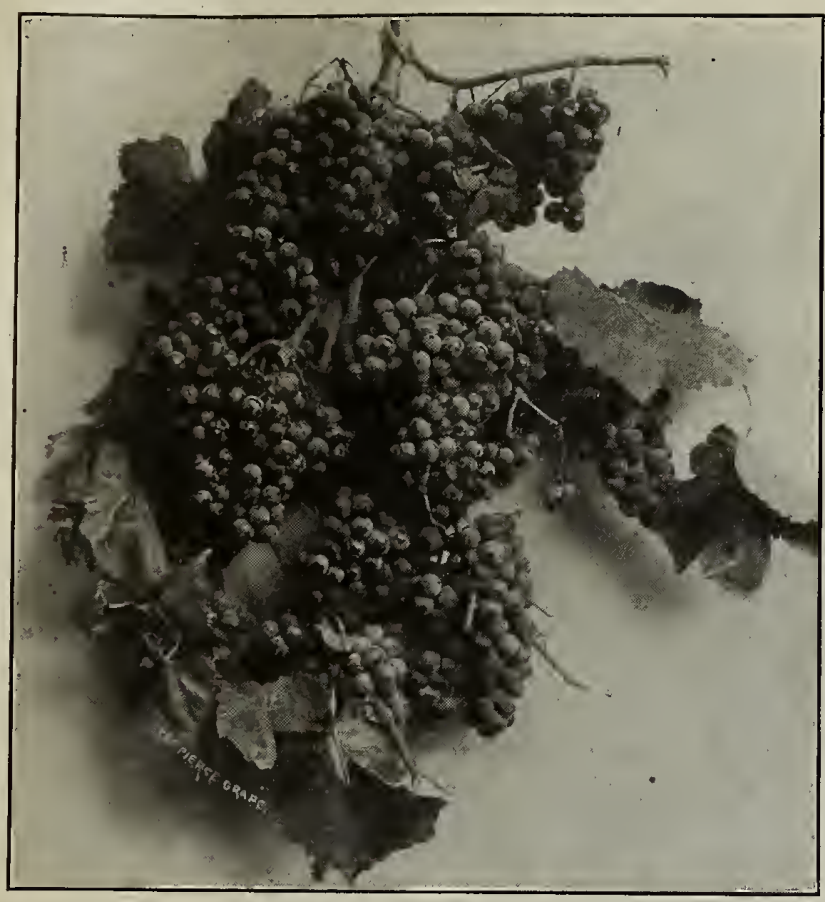

The Pierce Grape

count of the severe winters. They are also the best for arbor and trellis covering.

CATAWBA. Bunches large and loose; berries round, of a coppery red color, vinous and rich.

CONCORD. Bunches large, compact; berries large, round, light, red, sweet.

MOORE'S DLAMOND. Vine a vigorous grower, with large, dark, healthy foliage, which is entirely free from mildew. It is a prolific bearer, producing large, handsome, compact bunches, slightly shouldered. The color is a delicate greenish white, with a rich yellow tinge when fully ripe; skin smooth; very few seeds; juicy, and almost entirely free from pulp; berry about the size of Concord, and adheres firmly to about the
the stem.

NIAGARA. Bunch large, uniform, very compact; berry large, mostly round, light greenish white, slightly ambered in the sun; peculiar flavor and aroma. Enormously productive.

THE PIERCE. A sport from the Isabella. It is an immense bearer and strong grower.

WORDEN. Bunches large and compact; berries large, black.

\section{Currants}

Currants and Gooseberries should be planted in good soil, which must be kept rich and well worked. Trim out the old wood as soon as it begins to decline, and shorten all the young shoots, to keep the bushes in good shape. Sprinkle ashes around the roots occasionally, to keep the borers away.

Strong, 2 years old, 20c each; $\$ 1.75$ per 10.

BLACK NAPLES. Berries large and black.

CHERRY CURRANT. Very large, deep red. One of the best.

LONDON MARKET. Very productive, with long branches covered with large, rich, red-colored fruit.

WHITE DUTCH. Bunch and berry large, with fine transparent skin.

\section{Gooseberries}

We can supply the following English sorts. Large fruiting, and of delicious flavor. 2-year-old plants, 25c CROWN BOB. Large roundish, oval, red, hairy; of first
quality.
INDUSTRY. Immensely prolific; large and handsome; ripens very early; color, dark red.

KEEPSAKE. A very large straw-colored gooseberry, of excellent fiavor; one of the earliest.

LANCASHIRE LAD. This splendid sort is of superior quality, almost as large as Industry, having a rich pleasant flavor when ripe; color, rich dark red; a vigorous grower.

WHITESMITH. Large, oval shaped; yellowish white, slightly downy; of first quality.

\section{Raspberries}

Plant in rows 5 to 6 feet apart 2 to 4 feet in the row Cut the tops off within a few inches of the ground when planted. After the fruit season, cut out all the old wood which bore the last crop of fruit. Pinch the vigorous young shoots several times during the summer. They will then grow stout enough to stand without staking.

\section{RED VARIETIES.}

Price, 60c per 10; $\$ 4.00$ per 100 .

CUTHBERT (Queen of the Market). The largest, handsomest and best red Raspberry cultivated. Bears transportation well. Very productive.

TURNER RED. Of rich flavor and very good quality Time of ripening is with the earliest and continued until the end of the raspberry season.

YELLOW VARIETIES.

Price, 10c each; 75c per 10.

CAROLINE. A very productive variety; fruit very large; of bright orange color.

GOLDEN QUEEN. A seedling or "sport" of the Cuthbert and in hardiness and vigorous growth of the plant resembling that variety. Fruit of large size. Color resembling that variety. Fruit of lar

\section{BLACK CAP VARIETIES. \\ Price, 10c each; 75c per 10.}

GREGG. One of the most valuable of this class. Fruit large, good quality.

SCHAFFER'S COLOSSAL. A strong grower; berries large and of good quality. Very productive.

\section{Blackberries}

Plant in good soil, in rows 5 to 6 feet apart, and 3 to 4 feet apart in the row. After the fruiting season, or in early spring, cut out all the dead wood. Blackberries should be planted early, before the buds start. A good top dressing of stable manure, applied annually, will be conducive to large crops. Keep the ground clean.

Price, $60 \mathrm{c}$ per $10 ; \$ 4.00$ per 100 , except where noted otherwise.

CRANDALL'S EARLY. Large, firm, and very good flavor. It ripens fully two weeks before any other sort, and continues to bear through the whole blackberry season.

KITTATINNY. Fruit large, roundish conical, rich glossy black; firm, juicy, sweet and excellent.

LAWTON. Fruit large; very productive and late.

HIMALAYA GIANT. A late Blackberry coming after the other berries are gone, ripening over a period of several weeks, making it especially desirable for family use. In Northern California they are seldom injured by frost, as they blossom after all frosts are over. Like the Loganberry, it must be grown on a trellis-the vines under favorable conditions growing 15 to 20 feet. The berries grow in bunches; are of excellent flavor and the yield surpasses any berry ever introduced. Large one year old plants, 30 c each; $\$ 2.50$ per 10 . Tip rooted plants ready end of February, 15c each; $\$ 1.00$ per $10 ; \$ 6.00$ per 100 .

\section{MAIMIMOTH BLACKBERRY}

\section{Named by some "The Black Loganberry"}

The fruit is enormously large, some specimens measuring from $2 \frac{1}{4}$ to $2 \frac{1}{2}$ inches long; the very largest blackberry known to the world. The globules are large, 


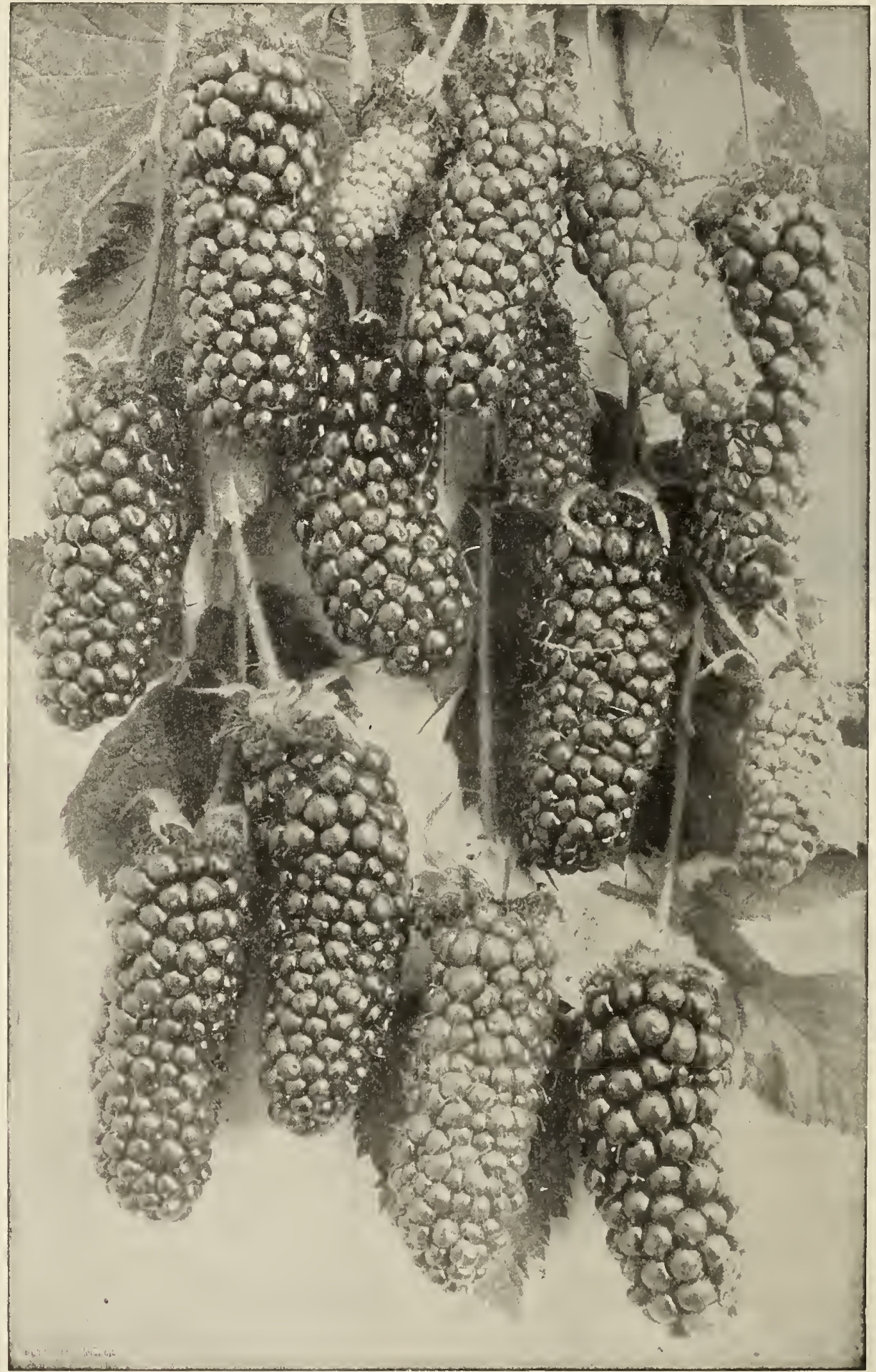

Mammoth Blackberry

seed small, soft and not very abundant; core quite small and very soft. The flavor is a decided improvement on any known variety of blackberry, the acid flavor so pronounced in all other kinds is very mild and pleasant, and when fully ripe is quite sweet. This berry in size and delicious flavor will eclipse any blackberry heretofore produced.
It is advisable in planting the Mammoth Blackberry plants that they be given plenty of room. If grown upon a trellis, which is by far the best way, the rows should not be less than 9 feet apart and the plants 6 to 8 feet in the rows.

Large one year old plants (as long as they are in stock) $20 \mathrm{c}$ each; $\$ 1.50$ per 10. 
Tip rooted ready end of February. $10 \mathrm{c}$ each; $75 \mathrm{c}$ per $10 ; \$ 4.00$ per 100 .

\section{Strawberries}

To cultivate the Strawberry for family use we recommend planting in beds four feet wide, with an. alley two feet wide between the beds. These beds will accommodate three rows of plants, which may,stand fifteen inches apart each way, and the outside row nine inches from the alley. The beds can be kept clean easier and the fruit gathered without setting feet upon them. The ground should be well prepared by digging or plowing at least ten or twelve inches deep, and be enriched with well rotted manure, ground bone, wood ashes or any other good fertilizer.

Price, 25 c per dozen; $\$ 1.50$ per $100 ; \$ 8.00$ per 1,000 .

Varieties marked (Imp.) are imperfect in blossom and need at least every third or fourth row to be planted with some perfect or staminate sort. Those marked (Per.) are especially good to use as staminates or to be grown alone.

BRANDYWINE. (Per.) Plant a luxuriant grower, healthy and hardy, and very productive; blossom perfect; fruit very large, of good form, bright red all over, and of good quality. Season, medium to very late. It succeeds on any soil.

EXCELSIOR. (Per.) Berries large, long, conical or pointed and a bright scarlet in color. The flesh is bright, juicy, of fair quality, and frrm. Plants vigorous and healthy in growth and foliage. Ripens early and is very productive. HAVERLAND (Imp.) A large long berry; bright crim-
son; very handsome; very productive; juicy with mild flavor.

LADY THOMPSON. (Per.) Early; very productive; large; firm and fine flavor. A valuable market variety. Plant, strong and vigorous grower.

LONGWORTH. (Imp.) An old popular variety. Fruit small, very sweet. Requires to have a perfect variety to be planted in proximity.

NEW YORK. (Per.) Produce berries of largest size, of fine appearance and good quality.

SPLENDID. (Per.) Fruit smooth, bright red. It is firm, a good keeper, and has a perfect blossom. Plant very healthy in growth. A good berry.

\section{The Logan Berry \\ (Raspberry-Blackberry)}

The fruit is as large as the largest-sized blackberry; is of the same shape, with globules similar to that fruit. Color, when fully ripe, a dark rich red. It partakes of both flavors of the raspberry and blackberry, being a combination of the two mixed; a very pleasant, mild, vinous flavor, delightful to the taste, not found in any other fruit, but peculiar to this alone. It is excellent for the table, eaten fresh or cooked, and for jellies or jams without an equal. The vines are enormous bearers. Tip rooted ready about end of February. $10 \mathrm{c}$ each; 75 c per $10 ; \$ 4.00$ per 100 .

\section{The Phenomenal Berry}

Is the result of a cross between the Improved California Dewberry and the Cuthbert Raspberry. Mr. Burbank (the introducer) describes is as larger than the largest berry ever before known; bright crimson raspberry color; productive as could be desired. Tip rooted ready about end of February. 15c each; \$1.00 per 10.

\section{New Dewberry GARDENA}

The Gardena has proven itself a most valuable fruit for Southern California. It is remarkably early, ripening its fruit in April and May, and in productiveness is a surprise to fruit-growers, having the past season far exceeded that of any other variety of its class. The fruit is large, firm, of superior flavor, and very attractive in its appearance. Grow them upon a low trellis, not over 2 feet high; plant the rows 5 feet apart; plants
3 feet apart; put up two wires, one a foot from the ground, the other not over 2 feet-better 20 inches. 15 c each; $\$ 1.00$ per $10 ; \$ 6.00$ per 100 .

HORSERADISH

Strong plants, $15 \mathrm{c}$ each; $\$ 1.00$ per 10 .

\section{Rhubarb}

LORENZO AND LINNAEUS. Strong roots, 15e each; $\$ 1.50$ per dozen.

\section{AUSTRALIAN CRIMSON WINTER}

The great value of Rhubarb as a vegetable has always been its earliness, and a vast amount of time and labor has been spent in efforts to originate a variety which would produce stalks even a day or two in advance of other early varieties. Australian "Crimson Winter" Rhubarb will produce marketable stalks abundantly, fully six months earlier than any other Rhubarb. Price, $25 \mathrm{c}$ each; $\$ 2.00$ per 10 . Strong roots, $50 \mathrm{c}$ each; $\$ 5.00$ per dozen.

\section{SPRAYING FORIMULAS}

BORDEAUX MIXTURE. Copper sulphate, 6 pounds quicklime, 4 pounds: water, 40 gallons. Dissolve the and hanging this in a vessel holding at least 4 gallons, so that it is just covered by the water. Use an earthern so that it is just covered by the water. Use an earthern or wooden vessel. Slake the lime in an equal amount of water. Then mix the two and add enough water. to
make 40 gallons. It is then ready for immediate use. If the mixture is to be used on peach foliage it is advisable to add an extra pound of lime to the above formula. When applied to such plants as carnations or soap be dissolved in hot water and added to the mixture. soap be dissolved in hot water and added to

A rots, mildews, and all fungous diseases. bonate, 1 ounce; ammonia (1 volume 26 per cent Beaume, $7 / 8$ volume of water), enough to dissolve the copper; water, 9 gallons. The copper carbonate is best dissolved in large bottles where it will keep indefinitely, and it should be diluted with water as requircd. For the same purposes as Bordeaux Mixture.

COPPER SULPHATE SOLUTION. Copper sulphate, 1 pound; water, 15 gallons. Dissolve the copper sulphate in the water, when it is ready for use. This should never be applied to foliage, but must be used before the buds break. For peaches and nectarines use 25 gallons of water. For fungous diseases.

PARIS GREEN. Paris green, 1 pound; water, 200-300 gallons. If this mixture is to be used upon peach trees, 1 pound of quicklime should be added. Repeated applications will injure most foliage unjess lime is added. Paris green and Bofdeaux mixture can be applied together with perfect safety. Use at the rate of four ounces of the arsenites to 50 gallons of the mixture. The action of neither is weakened, and the Paris green loses all caustic properties.

an is used in the same propor列 applied with two or three times its weight of lime, or with the Bordeaux mixture. The composition of London purple is exceedingly variable, and unless good reasons exist for supposing that it contains as much arsenic as Paris green, use the latter poison. Do not use London purple on peach or plum trees unless considerable lime s added.

HELLEBORE. Fresh white hellebore, 1 ounce; water, 3 gallons. Apply when thoroughly mixed. This poison is not so energetic as the arsenites and may be used a not so energetic as the arsenites and may be

KEROSENE EMULSTON. Hard soap, $1 / 2$ pound; boiling water, 1 gallon; kerosene, 2 gallons. Dissolve the soap in the water, add the kerosene, and churn with a pump for 5 to 10 minutes. Dilute 10 or 25 times before applyinp. Use strong emulsion for all scale insects. For insects which suck, as plant lice, mealy bugs, red spider. thrips, bark-lice or scale. Cabbage worms, currant worms and all insects which have soft bodies can also be successfully treated.

DISTANCES FOR PLANTING FRUIT TREES Standard Apples .......25 to 30 feet apart each way Standard Pears.........20 to 25 feet apart each way Strong Growing Cherries..20 to 25 feet apart each way Strong Growing Cherries..20 to 25 feet apart each way Standard Plums and Prunes.18 to 20 feet apart each way Apricots, Peaches, Nectar-

ines................... to to 20 feet apart each way

Currants, Gooseberries, and Loganberries.

Raspberries and Blackberries

Strawberries for Garden Culture. 


\section{TABLE OF CONTENTS}

\section{Garden Seeds}

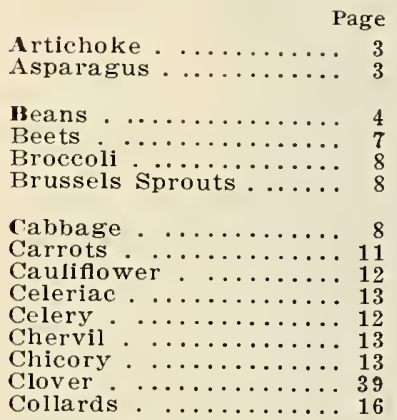

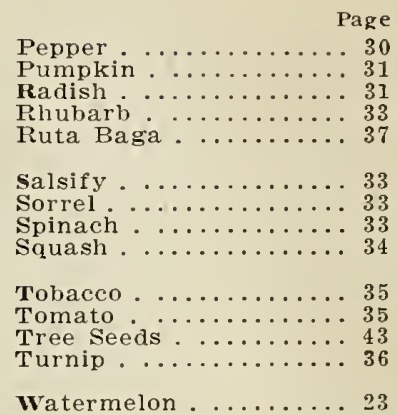

\section{Fjower Seeds}

All linted alphabetically, 46 to 66. Note Sveet Peas, pages 63 to 66 -Xeranthemum, page $66-Z i n n i a$, page 66.

\section{INDEX FOR PLANT DEPARTMENT}

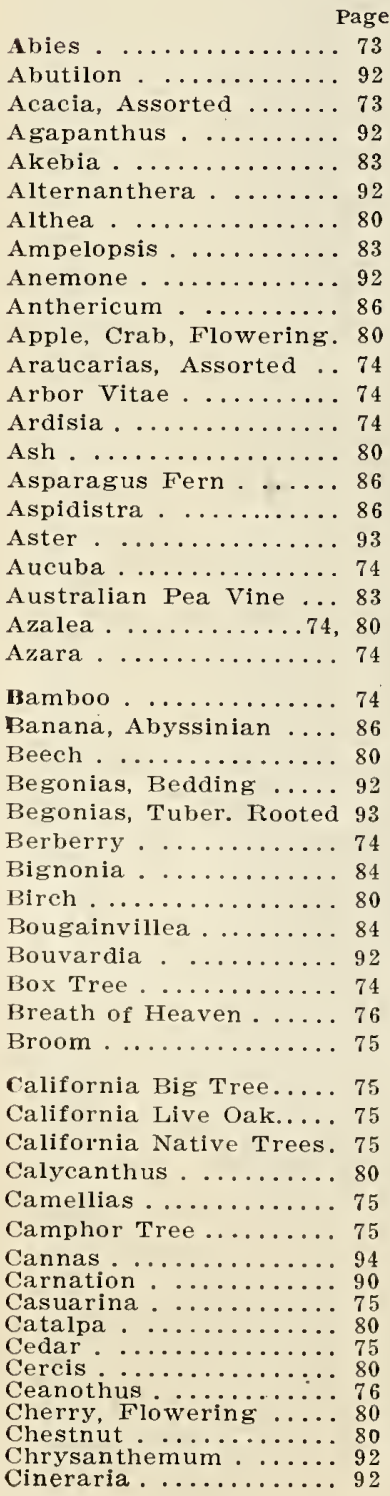

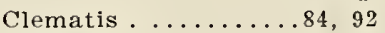

Coleus .................... 86

Corchorus . ........ 80

Coreopsis .......... 92

Cosmos ............ 92

Crape Myrtle........ 80

Cryptomeria . ....... 76

Currant, Flowering..... 80

Cyclamen .......... 86

Cypress ........... 76

Dahlias ............ 87

Daisies . ............ 9

Daphne.......... 76

Deutzia ............. 80

Diosma . ......... 76

Dogwood . .......... 80

Dracaena......... 86

Echeveria . ........ 92

Elm .............. 80

Eloeagnus . ........ 80

Eucalyptus, Assorted .. 76

Eugenia . ......... 76

Eulalia ........... 86

Fuonymus ......... 77

Exochorda ......... 81

Fabiana ........... 77

Ferns . .......... 87

Ficus ..........84, 86

Forsythia . ........ 81

Fruit Trees ......... 94

Fuchsia . .......... 92

Gaillardia . ......... 92

Gazania ............ 92

Geranium ........... 91

Gloxinia ............ 93

Golden Feather.......992

Grapes .......................

Grevillea ........... 77

Habrothamnus ....... 77

Heath . .......... 77

Helianthus . ........ 92

Heliotrope ..........92

Holly ............. 77

Honeysuckle .....81, 84

Hop Vine . . . . . . . . . 85

Horse Chestnut . ..... 81

Hydrangea . .......81,93

Hypericum . ....... 81

\begin{tabular}{|c|c|}
\hline Page & Page \\
\hline$\ldots \ldots \ldots \ldots \ldots 92$ & Phlox \\
\hline pis . ........ 86 & Pine ............ 78 \\
\hline .. 85 & $\begin{array}{l}\text { Pittosporum . . . . . . . } 78 \\
\text { Plum, Purple Leaved... } 82\end{array}$ \\
\hline randa... & Plumbago......... 85 \\
\hline ne...... & Polygala . ........ 79 \\
\hline 77 & Pomegranate....... 82 \\
\hline orreu & $\begin{array}{l}\text { Poplar } \ldots \ldots \ldots \ldots \ldots \ldots \\
\text { Primula } \ldots \ldots \ldots \ldots \ldots \ldots\end{array}$ \\
\hline burnum & ee Ligustrum. \\
\hline
\end{tabular}

Larch .............. 81

Laurel ............ 77

Laurustinus . ....... 78

Lemon Verbena .......81

Libocedrus .......... 78

Ligustrum .......... 78

Lilac ............. 81

Linden . .......... 81

Lippia . . . . . . . . . 93

Lobelia . . . . . . . . 93

Locust . .......... 81

Loquat . .......... 78

Magnolia . . . . . . . 78, 82 Maiden Hair Tree..... 81

Maple............ 81 Marguerite ......... 93 Mesembryan themum . ..93 Metrosideros ....... 78 Mock Orange ........ 82 Mountain Ash ....... 82 Muehlenbeckia ..... 85 Mulberry . ......... 82 Myrtle ................ 78

Nandina ........... 78 New Zealand Flax .... 78

oak.............. 89 Olea fragrans ....... 78 Oleander ............ 78 Paeonias .........93,94 Palms.............. 85 Pampas Grass ....... 85 Pansy ............. 93 Passion vine........... 85 Peach, Flowering ..... 82 Paulownia......... $\$ 2$ Pelargonium ......... 91 Pepper Tree........ 78 Petunia ........... 93 Photinia .......... 78
Quince, Flowering .... 82

Redwood ...........75

Retinospora ........ 79 Rhododendron ....... 79 Rhubarb, Australian Win-

ter, and other sorts...103

Rhus............ 82 Roses ..........67-72 Rubber Tree........ 86

Salvia ............ 93 Sea Pink.......... 93 Shasta Daisy . ....... 92 Small Fruits .........101 Smilax .......... 85 Snowball .......... 83 Solanum ........... 85 Spergula .......... 93 Spiraea ........... 83 Spruce. See Abies. Swainsona......... 79 Sweet Bay. See Laurel.

Tamarix ........... 83 Tecoma........... 85 Texas Umbrella Tree... 83 Thorn........... 83 Thuja............ 79 Thujopsis .......... 79 Tritoma .......... 86 Tulip Tree .......... 83

verbena............ 93 Veronica........... 79

Vinca ............ 85

Violets.................... 92

Wainut ........... 83 WVeigilea ............ 83 Willow ............ 83

Yew.................
Stocks ............ 93 Wistaria ............ 


\section{BY THE BEST AUTHORS}

Treating on the Cultivation of Flowers, Trees, Shrubs, Fruits and Vegetables, the Study of Botany and Horticulture in General Postage must be added; $5 \mathrm{c}$ for books priced at $50 \mathrm{c}$ and under; $10 \mathrm{c}$ for books priced over $50 \mathrm{c}$ to $\$ 1.50 ; 20 \mathrm{c}$ for others.

A Woman's Hardy Garden. By Mrs. Ely...............\$1.75

Alfalfa. By F. D. Coburn.................... .50

Apple Culture. By Prof. L. H. Bailey. Giving much valuable instruction on the subject of this fruit, from plant-

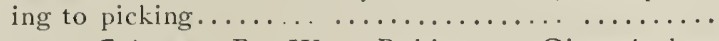

Asparagus Culture. By Wm. Robinson. Gives the best methods of cultivation by experienced growers........

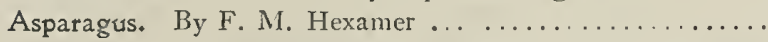

Barn Flans and Outbuildings. A valuable work; full of ideas, hints, suggestiors, plans etc., for the construction of barns and outbuildings, by practical writers ...

Botany, the Treasury of. A popular dictionary of the Vegetable Kingdom, giving a concise account of all known plants in language devoid of all dry technical terms; of nuch interest to the professional, and as a work of reference for the amateur student it stands unrivaled. Two volumes, beautifully illustrated with numerous steel-

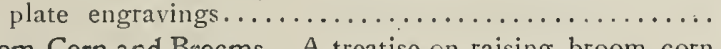

Broom Corn and Brocms. A treatise on raising broom corn
and making brooms on a small or large scale.........

California Vcgetatles in Garden and Field. By Prof. E. J. Wickson. A manual of practice with and without irrigation; beautifully illustrated. Out of print until

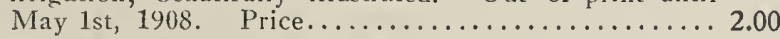

California Fruits and How to Grow Them. BV Prof. E. J. Wickson. Out of print until May 1st, 1908. Price... 2.50

Carrots, Mangelwurzels, Etc. By J. J. H. Gregory. How to raise them, how to keep them and how to feed them..

Farm Appliances. Describing numerous useful and laborsaving appliances which will be found of great value in every department of farm work

Farm Drainage. By Judge French. Describes the principle, process, and effects of draining land, and other valuable

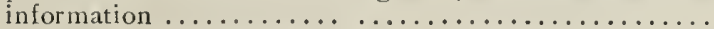

Fences, Gates and Bridges. A much-needed and valuable

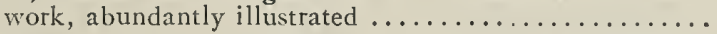

Fertilizers. By J. J. H. Gregory. Tells how and where to obtain in cheapest form; how to compound formulas, etc.

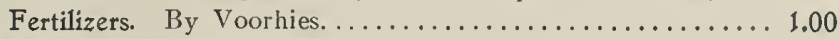

Flowers, and How to Grow Them. By E. E. Rexford. This little work, intended for the amateur, gives some very good instructions regarding the selection of plants for the house or garden and how to care for them .........

Forage Plants Other Than Grasses. By Thos. Shaw. 287 pages scientific, accurate information on this subject...

Forestry, Practical. By A. S. Fuller. A treatise on the propagation, planting and cultivation, with a description and botanical and popular names of all the indigenous trees of the United States.................... 1.50

Forcing Book. By L. H. Bailey................. 1.00

Fumigation Methods, By Willis J. Johnson. Showing simple and effective means of exterminating insect pests and vermin, being the outcome of practical tests of the author and others

Gardening for Pleasure. By Peter Henderson. Tells how to grow flowers, vegetables, and small fruits in the garden and greenhouse; also treats fully on window and house

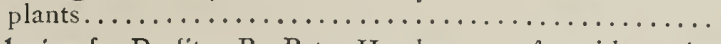

Gardening for Profit. By Peter Henderson. A guide to the successful culture of the market and family garden.... 1.50

Garden IMaking. By Prof L. H. Bailey. Instructions for beginners and for the skillful gardener. Covers the whole subject, laying out and planting small city yards and large suburban grounds, plants, trees, bedding, pruning, vegetables, fruits; scientific truths in simple language

Grape Culturist. By A. S. Fuller. One of the best works on the cultivation and management of hardy grapes....
Grasses and Forage Plants. By Charles L. Flint. Varieties, nutritive values, culture, curing, management of grass lands, etc. Accurately described in a work of 400 pages, containing nearly 200 illustrations of our most common grasses and a large number of others not so well known, 2.00

Handbook of Plants. By Peter Henderson. A concise and comprehensive dictionary of plants, with instructions on propagation and culture.

Horticulturist Rule Book. By Prof. L. H. Bailey. Full of useful information for fruit grower, truck gardeners, florists and others...

Irrigation Farming. By Lucius Wilcox. The application of water in the production of crops, appliances, principles and advantages.

Irrigation for Farm, Garden and Orchard. By Henry Stewart. Methods and management to secure water for critical periods.

King's Irrigation and Drainage

Making Manures, Boomer's Methods. A practical and comprehensive guide for making manures on the farm...

Mushroom Culture. By Wm. Robinson. A practical guide to succesful production of this crop.

Nursery Book. By Prof. L. H. Bailey. This is a complete handbook of propagation of plants. Tells in plain language what every one who sows a seed, makes a cutting,

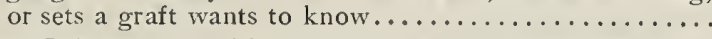

Onion Culture. By T. Greiner. For the home garden or the market; new and highly valuable methods are described....

Peanut Plant. By W. B. Jones. Instructs the beginner on

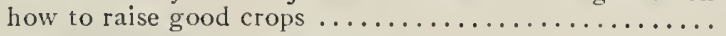

Plant Breeding. By L. H. Bailey .................
Practical Floriculture. By Peter Henderson. As a guide to the successful propagation and cultivation of florists" plants nothing has been left unsaid on the subject.

Practical Garden Book. By L. H. Bailey............. 1.00

Principles of Agriculture. By L. H. Bailey........... 1.25

Principles of Vegetable Gardening. By L. H. Bailey...... 1.25

Propagation, Art of. By- J. Jenkins. A concise, practical treatise detailing the management in propogation of

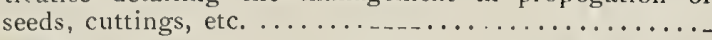

Pruning Book. By Prof. L. H. Bailey, Where, how and when to prune fruit and ornamental trees and shrubs...

Rose, The+ By H. B. Ellwanger. Contains full dirctions for planting, pruning, propagating, and valuable in

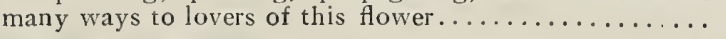

Silos, Silage and Ensílage. By Manley Miles. Practical treatise on ensilage of fodder, corn, etc.............

Small Fruit Culturist. By A. S. Fuller Rewritten, enlarged, and up to date; propagation, culture, varieties, market-

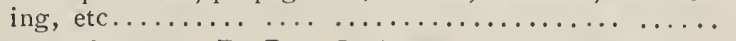

Spraying of Plants. By Prof. Lodeman. Insects and fungi; liquids and powders; application and apparatus.........

Strawberry Culturist. By A. S. Fuller. Full directions for field and garden culture, forcing or pot culture, etc.....

Sweet Potato Culture. By James Fitz. Full directions from starting the plants to harvesting and storing ...........

Swine Husbandry. By F. D. Coburn. Breeding, rearing, and management treatment, and preservation from disease,

The Garden Book of California. By Belle Sumner Angier.

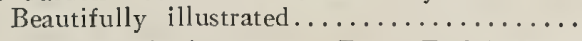

The New Rhubarb Culture. By J. E. Morse..

Tobacco Culture. Full practical details by fourteen experienced growers in different sections of the country...

Wild Flowers of California. By Mary E. Parsons and Margaret W. Buck ........................ 2.00 


\section{UKDER SEED SHEET C. C. MORSE \& Co. successors to COX SEED CO.}

$$
\text { Retail Store }
$$

125-127 MARKET STREET

Office and Warehouse

8-56 JACKSON STREET

Date,

190

Enclosed find $\$$

Name

Post Office

County

State

\section{Forward this order by.}

VERY IMPORTANT-No matter how often you write us, always be carefu to give full name and address. Write name very plainly. State how to forward-whether by freight, express or mail.

\section{SEEDS POSTPAID BY MAIL}

We mail and pay postage on all seeds in PACKETS, OUNCES and $1 / 4$ POUNDS purchased from this $C$ atalogue. On larger quantities add $10 \mathrm{c}$ per pourd to $C_{a}$ taogue prices for postage. 


\section{ORDER Plant and Tree SHEET C. C. MoRse \& Co.}

successors to COX SEED CO.

Retail Store

125-127 MARKET STREET offlce and Warehouse SAN FRANOISCO, CALIFORNIA.

Date,... 190.

Enclosed find \$.

Name

Post Office

County

State.

Forward this order by

On Plant Orders please add $10 \%$ for packing to cover actual cost of material. All orders for Trees and Plants will be shipped from our nurseries in Oakland. 
Amount brought forward,

$$
\text { SPECIAL NOTICE: We shall esteem it a great favor if you will give us below the }
$$
NAMES and ADDRESSES of any of your friends that are interested in gardening. We wish to send them our CATALOGUE.

NAME

POST OFFICE STATE 


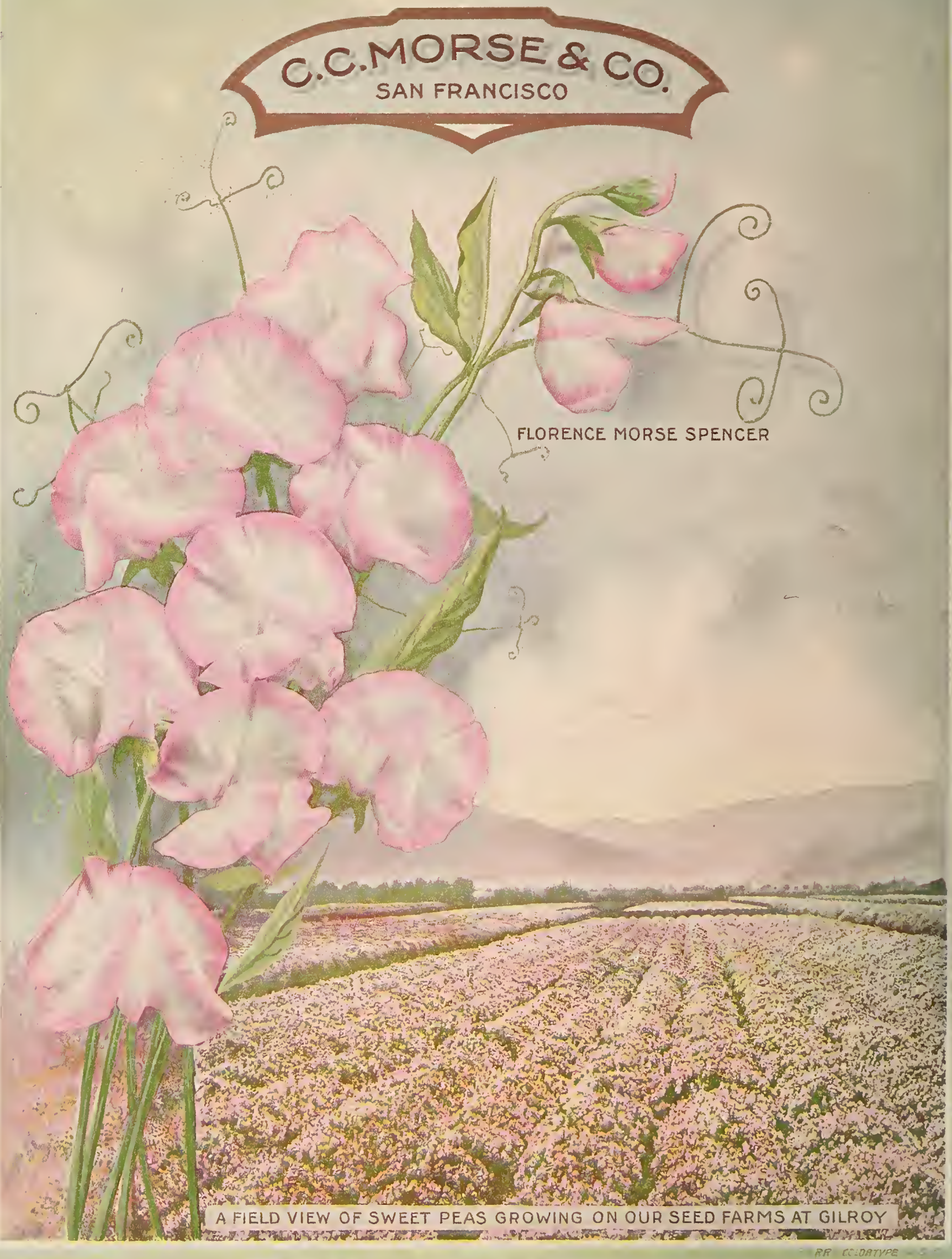

